\section{НОВАЯ НАУКА}

Международный центр научного партнерства
NEW SCIENCE

International Center for Scientific Partnership

\title{
СТРАТЕГИЯ \\ НАУЧНО-ТЕХНОЛОГИЧЕСКОГО \\ РАЗВИТИЯ РОССИИ: ПРОБЛЕМЫ И ПЕРСПЕКТИВЫ РЕАЛИЗАЦИИ
}

Монографрия

г. Петрозаводск

МЦНП «Новая наука»

2022 
УДК 001.12

ББК 70

$\mathrm{C} 83$

Рекомендовано к публикации редакиионной коллегией МЦНП «Новая наука»

\section{Рецензенты:}

Ершова Л.В.

доктор педагогических наук

ФГБОУ ВО «Ивановский государственный университет»

Андрианова Л.П.

доктор технических наук

ФГБОУ ВО «Уфимский государственный нефтяной технический университет»

\section{Коллектив авторов:}

Андрианова Л.П., Белоножко М.Л., Гадзаова Л.П., Гордеева В.В., Данилов О.Ф., Ибрагимов А., Ковалева И.Е., Котова Е.Г., Кузнецова Н.В., Леонтьева А.В., Леонтьева Т.А., Линева Е.А., Лихтенштейн Б.М., Логинов С.И., Назаренко И.М., Назарова А.С.,

Савельева Е.Б., Сирожиддинов 3., Соколенко В.В., Таланова М.В., Чумаков А.А., Юсупова Т.Г., Яхшибоев Ш.Р.

СТРАТЕГИЯ НАУЧНО-ТЕХНОЛОГИЧЕСКОГО РАЗВИТИЯ РОССИИ: ПРОБЛЕМЫ И ПЕРСПЕКТИВЫ РЕАЛИЗАЦИИ : монография / [Андрианова Л. П. и др.]. - Петрозаводск : МЦНП «Новая наука», 2022. — 298 с. : ил. - Коллектив авторов.

ISBN 978-5-00174-461-0

DOI 10.46916/04022022-978-5-00174-461-0

В монографии рассматриваются актуальные вопросы, стоящие перед современными исследователями, предлагаются оригинальные решения научно-методических и технологических вопросов. Издание может быть полезно научным работникам, специалистам-практикам, преподавателям всех уровней образования, интересующимся проблемами развития современной науки и образования.

Авторы публикуемых материалов несут ответственность за содержание своих работ, точность цитат, легитимность использования иллюстраций, приведенных цифр, фактов, названий, персональных данных и иной информации, а также за соблюдение законодательства Российской Федерации и сам факт публикации.

Полные тексты статей в открытом доступе размещены в Научной электронной библиотеке Elibrary.ru в соответствии с Договором № 467-03/2018K от 19.03.2018 г.

ISBN 978-5-00174-461-0 


\section{ОГЛАВЛЕНИЕ}

\section{РАЗДЕЛ І. ЧЕЛОВЕК И СОВРЕМЕННОЕ ОБЩЕСТВО}

В СОЦИАЛЬНО-ЭКОНОМИЧЕСКОМ РАКУРСЕ

ГЛава 1. ПРЕДПОСЫЛКИ ФОРМИРОВАНИЯ ИНСТРУМЕНТОВ

ИННОВАЦИОННО-ТЕХНОЛОГИЧЕСКОГО РАЗВИТИЯ:

ТЕХНОЛОГИЧЕСКИЕ ПЛАТФОРМЫ

5

Кузнеиова Наталия Викторовна

ГЛава 2. РАЗВИТИЕ ЧЕЛОВЕЧЕСКОГО ПОТЕНЦИАЛА - ВАЖНЕЙШЕЕ

УСЛОВИЕ ОБЕСПЕЧЕНИЯ ЭКОНОМИЧЕСКОЙ БЕЗОПАСНОСТИ

ОРГАНИЗАЦИИ В УСЛОВИЯХ ПАНДЕМИИ

Чумаков Александр Александрович, Ковалева Инна Евгеньевна,

Назаренко Ирина Михайловна

ГЛАВа 3. ОЦЕНКИ ПОТЕНЦИАЛА РАЗВИТИЯ Г. ТЮМЕНИ

НА ПУТИ К УМНОМУ ГОРОДУ

Данилов Олег Фёдорович, Логинов Станислав Игоревич,

Лихтенштейн Борис Максимович, Белоножко Марина Львовна

РАЗДЕЛ ІІ. ОБУЧЕНИЕ, РАЗВИТИЕ, ВОСПИТАНИЕ ЛИЧНОСТИ СЕГОДНЯ.

ГЛава 4. ЦЕЛЕСООБРАЗНОСТЬ СМЕНЫ ФУНДАМЕНТАЛЬНЫХ

ОСНОВ ОБУЧЕНИЯ ИНОСТРАННОМУ ЯЗЫКУ СТУДЕНТОВ

НЕЯЗЫКОВЫХ СПЕЦИАЛЬНОСТЕЙ БОЛЕЕ ЭФФЕКТИВНЫМИ

ОБРАЗОВАТЕЛЬНЫМИ СТРАТЕГИЯМИ

Гадзаова Л.П.

ГЛава 5. ФОРМИРОВАНИЕ ЭМОЦИОНАЛЬНОГО ИНТЕЛЛЕКТА

У ДЕТЕЙ В ПЕРИОД ДОШКОЛЬНОГО ВОЗРАСТА

Гордеева Вероника Викторовна, Назарова Александра Сергеевна,

Таланова Марина Викторовна

Глава 6. ЭТИМОЛОГИЧЕСКИЙ АНАЛИЗ АНГЛИЙСКИХ

ПАРЕМИЙ С КОМПОНЕНТОМ «ЈАСК»

Котова Елена Геннадьевна, Линева Елена Александровна,

Савельева Елена Борисовна, Юсупова Татьяна Геннадьевна,

Леонтьева Алесья Вячеславовна 
РАЗДЕЛ ІІІ. ДИССЕМИНАЦИЯ ИННОВАЦИОННОГО

ТЕХНОЛОГИЧЕСКОГО ОПЫТА..................................................................... 168

Глава 7. МЕТОДОЛОГИЯ ФУНКЦИОНАЛЬНЫХ ИСПЫТАНИЙ

УСТРОЙСТВ ЗАЩИТЫ ОТ ОДНОФАЗНЫХ ЗАМЫКАНИЙ

НА ЗЕМЛЮ В ЭЛЕКТРИЧЕСКИХ СЕТЯХ 10 КВ С ПОМОЩЬЮ

COMTRADE-ФАЙЛОВ 168

Андрианова Людмила Прокопьевна, Леонтьева Татьяна Анатольевна,

Соколенко Владимир Владимирович

ГЛава 8. МЕТОДИКИ ОПРЕДЕЛЕНИЯ НЕСУЩЕЙ СПОСОБНОСТИ

ОДИНОЧНОЙ СВАИ И ЕЕ РАЗДЕЛЕНИЕ НА СОПРОТИВЛЕНИЕ

ГРУНТА ПОД ОСТРИЕМ И ПО БОКОВОЙ ПОВЕРХНОСТИ.

Сирожиддинов Зайниддин

Глава 9. АНТИСИММЕТРИЧНЫЕ КОЛЕБАНИЯ УПРУГОЙ

ТРЕХСЛОЙНОЙ ПЛАСТИНКИ

Яхшибоев Шерзод Рустамкулович

ГЛава 10. ЗАМКУТЫЕ ПРИЗМАТИЧЕСКИЕ ОБОЛОЧКИ

НА НЕОДНОРОДНОМ УПРУГОМ ОСНОВАНИИ

Ибрагимов Абдижаббар 


\title{
РАЗДЕЛ І. \\ ЧЕЛОВЕК И СОВРЕМЕННОЕ ОБЩЕСТВО \\ В СОЦИАЛЬНО-ЭКОНОМИЧЕСКОМ РАКУРСЕ
}

УДК 332.12

\section{Глава 1. \\ ПРЕДПОСЫЛКИ ФОРМИРОВАНИЯ ИНСТРУМЕНТОВ \\ ИННОВАЦИОННО-ТЕХНОЛОГИЧЕСКОГО РАЗВИТИЯ: \\ ТЕХНОЛОГИЧЕСКИЕ ПЛАТФОРМЫ}

\begin{abstract}
Кузнецова Наталия Викторовна докт. эконом. наук, профессор, профессор Департамент социально-экономических исследований и регионального развития, Школа экономики и менеджмента, Дальневосточный федеральный университет
\end{abstract}

Аннотация: Более 15 лет технологические платформы активно внедряются в качестве стратегии инновационно-технологического развития в различных странах мира. Сегодня рынки сами обретают архитектуру модульных платформ: платформа как технологическая конструкция (программная интеграция данных и приложений для их обработки); платформа как бизнес-модель; платформа как открытая, общедоступная инфраструктура. Трансформация рынков идёт очень быстро. Формирование такого рода экономики предполагает фундаментальную трансформацию, изменение архитектуры и масштабов существующих отраслей и социальной сферы, и сделать это возможно с помощью ТП. Опыт использования данного подхода в Европе говорит не только о его успехе, но и подчёркивает важность и 
эффективность подобного инструмента. Однако при всей известности механизма наблюдается некоторая неопределённость в возможностях технологических платформ. Для того чтобы составить целостное представление о концепции, был разработан подход, позволяющий подчеркнуть достоинства данного инструмента на теоретическом уровне. Также был проведен анализ актуальности технологических платформ в инновационной инфраструктуре России и оценка положения платформ в рамках других инструментов инновационно-технологического развития, что подчеркнуло важность и многогранность данного подхода в российской экономике.

Ключевые слова: технологические платформы, концепция, инновации, кластеры, технопарки, технологии, приоритетные направления, НИОКР, экономический рост.

\title{
BACKGROUND FOR FORMATION OF TOOLS FOR INNOVATION-TECHNOLOGICAL DEVELOPMENT: TECHNOLOGICAL PLATFORMS
}

\section{Kuznetsova Natalia Victorovna}

\begin{abstract}
For over 15 years technology platforms have been actively introduced as a strategy for innovative and technological development in various countries of the world. Today, the markets themselves acquire the structure of platforms and technological frameworks (program integration of data and applications for their processing); platform as a business model, platform as an open, public infrastructure. Transformation of the markets is going very fast. The formation of this kind of economy involves a fundamental transformation, change in the architecture and scale of existing industries and the social sphere; it can be done with the help of technological platforms. The experience of using this
\end{abstract}


approach in Europe speaks not only of its success but also emphasizes the importance and effectiveness of this tool. However, despite the success of the mechanism, there is some uncertainty in the capabilities of technological platforms. In order to create a holistic view of the concept, an approach was developed allowing to emphasize the advantages of this tool on a theoretical level. Also, an analysis was made of the relevance of technological platforms in the innovation infrastructure of Russia and an assessment of the position of the platforms in the context of other tools of innovation and technological development which emphasized the importance and diversity of this approach in the Russian economy.

Key words: technology platforms, concept, innovations, clusters, infrastructure, технопарки, technology parks, technologies, priority areas, global trends, R \& D, economic growth.

\section{1 Основы концепции технологической платформы}

Концепция практической реализации технологических платформ впервые была разработана в Евросоюзе. На данный момент его опыт является эталонным и самым продолжительным.

В начале двухтысячных годов Европейской Комиссией (ЕК) в рамках реализации задач по повышению конкурентоспособности EC, обозначенных в Лиссабонской стратегии, было начато формирование концепции европейской технологической платформы (ЕТП). Платформы были направлены на решение проблем координации инвестиций в НИОКР и объединения кооперации между различными промышленными и государственными субъектами. Это был первый опыт разработки и внедрения подобного инструмента инновационнотехнологического развития в мире [1;2].

В 2002 году в докладе ЕК «Industrial Policy in an Enlarged Europe» была представлена первая форма ЕТП, где они были обозначены как инструмент 


\section{СТРАТЕГИЯ НАУЧНО-ТЕХНОЛОГИЧЕСКОГО РАЗВИТИЯ РОССИИ: ПРОБЛЕМЫ И ПЕРСПЕКТИВЫ РЕАЛИЗАЦИИ}

разработки долгосрочных стратегических планов по исследованию и созданию технологий, потенциально обладающих положительным социальным и экономическом эффектом, а также как инструмент образования коммуникационного взаимодействия между стейкхолдерами [3; 4; 5].

Период с 2003 года по 2006 г. можно назвать как продвижение концепции. В 2003 году, ЕТП утвердили свою конечную форму как площадку, где посредством исследований и разработок определялись направления технологического развития региона. Данная концепция легла в основу 6-й рамочной программы, нацеленной на создание единого исследовательского пространства, выделение роли исследований и разработок в экономическом развитии, усиление интеграции между различными по масштабу участниками. В основном, упор в развитии ЕТП был сделан на расширение роли университетского сегмента в структуре платформы. В обозначенный период пришелся пик начального формирования европейских технологических платформ. За данный период сформировано 34 платформы [5; 6; 7].

В дальнейшем ЕТП не утратили своей значимости в процессах технологической модернизации экономики. Они продолжали свое развитие и в рамках 7-й рамочной программы, где усиливалось и выходило на новый уровень интеграционное взаимодействие между участниками в ходе инновационного процесса, формировались новые платформы [4; 8].

В текущей программе Европа-2020 обозначена переориентация исследований, разработок и инноваций на основные проблемы общества, что подразумевает определение новых приоритетов и способов их осуществления. В новой программе, ТП рассматриваются с другого ракурса в связи с осознанием слепых мест механизма. Предполагается выход платформ на новые разноуровневые экономические отношения для более эффективного решения социальных проблем. Также уделяется внимание тому, что ТП становятся связующим звеном в реализации программы, они способствуют продвижению 
участия промышленности, находят новые возможности для международного сотрудничества, содействуют с другими ТП для решения межсекторальных задач и продвижению к открытым моделям инноваций [9; 10].

Технологические платформы имеют ряд факторов, которыми обусловлено их возникновение. Первостепенно, необходимость разработки подобного механизма определяется наличием стратегических технологических вызовов, которая в свою очередь формирует недостаток развитости фундаментальных наук с использованием мультидисциплинарного подхода, научных коопераций и инструментов по решению возникающих в обществе проблем. Следует также отметить, что ТП имеют коммуникационный характер, тем самым решая проблему недостаточной структурированности бизнеса и степени его влияния на принятие стратегических приоритетов исследований и разработок. Появление технологических платформ также объясняется акцентированием проблемы применения инноваций и их коммерциализации, существующими барьерами между научными организациями, которые также определили потребность создания нового инструмента. Таким образом, появился новый инструмент, способствующий инновационному развитию технологические платформы.

Для ЕС технологические платформы стали важным элементом в усилении организации исследований и внедрении инноваций. Главными целями в развитии данного подхода является:

- нахождение способов решения социальных и экономических проблем в Европе посредством поддержки разработки и развертывания технологий, способных обеспечить экономический рост и повысить конкурентоспособность;

- определение стратегического видения в инновационнотехнологическом развитии Европы;

- стимулирование повышения доли частного инвестирования в исследования и разработки; 
- улучшение рынков инновационных продуктов.

Задачи, которыми определяется деятельность платформ обозначаются следующем: формирование стратегического плана исследования, который детализирует направление деятельности ТП, ее цели и сроки проведения исследований; разработку плана внедрения платформ, а также их продвижение и развитие.

Создание технологических платформ имеет свое начало исключительно от добровольно организующихся объединений заинтересованных сторон, где в качестве инициаторов обычно, выступают крупные промышленные компании и отраслевые объединения. Такой способ формирования был обозначен как «bottom-up process», где инициатива создания платформы исходит от любого сектора, а государство осуществляет лишь поддержку в ее запуске [5; 11].

Финансирование технологической платформы на организационной стадии обеспечивается ЕК, далее финансирование исходит из бюджета рамочных программ или из дополнительных национальных источников, также к финансированию ЕТП могут подключаться средства Европейского инвестиционного банка, Структурные фонды ЕС и т.д. На более поздней стадии функционирования ЕТП финансирование переходит на частный сектор.

Также следует отметить, что платформы с начала своего создания начинают следовать ряду принципов: формирование в интересах всего Европейского сообщества, открытость для вступления новых участников, интенсивное проведение НИОКР в процессе их деятельности, достижение консенсуса между стейкхолдерами и четкого структурирования платформы и определения финансирования, готовность к включению в исследование частных инвестиций [12].

Для понимания процесса функционирования платформ на основе европейской концепции нами представлен механизм ЕТП (рис. 4.). 
Выстраивание ТП происходит в три основных шага: создание платформы и настройка ее стратегического видения, формирование стратегического плана исследований и его внедрение. Мы предлагаем рассматривать еще один дополнительный этап - формирование инициативы, так как эта первая ступень в формировании ТП, где определяются цели по решению конкретных социальных и экономических вызовов, объединяются крупные компании сектора.

Формирование идеи о создании ЕТП происходит в результате четкого осознания потенциальных участников о необходимости выхода на новый уровень развития путем выстраивания новых взаимодействий и применения новых технологий, а также в результате понимания того факта, что ТП могут стать отличным инструментом способным ответить на существующие вызовы. Таким образом, импульс к созданию платформ исходит от необходимости решения острых экономических и социальных проблем, а инициатива рождается внутри заинтересованных лиц. Конечным направлением выстраивания подобной формы взаимодействия становится потребитель.

Зарождение ядра инициативы по созданию платформы происходит в ходе обсуждений по данному вопросу крупных отраслевых представителей, а также других заинтересованных сторон.

На рисунке 1 показано, что участники начинают выдвигать инициативу в отношении значимости подобного объединения. Вследствие чего, зарождается представление о существующих проблемах сектора развития, целях и направлениях. 


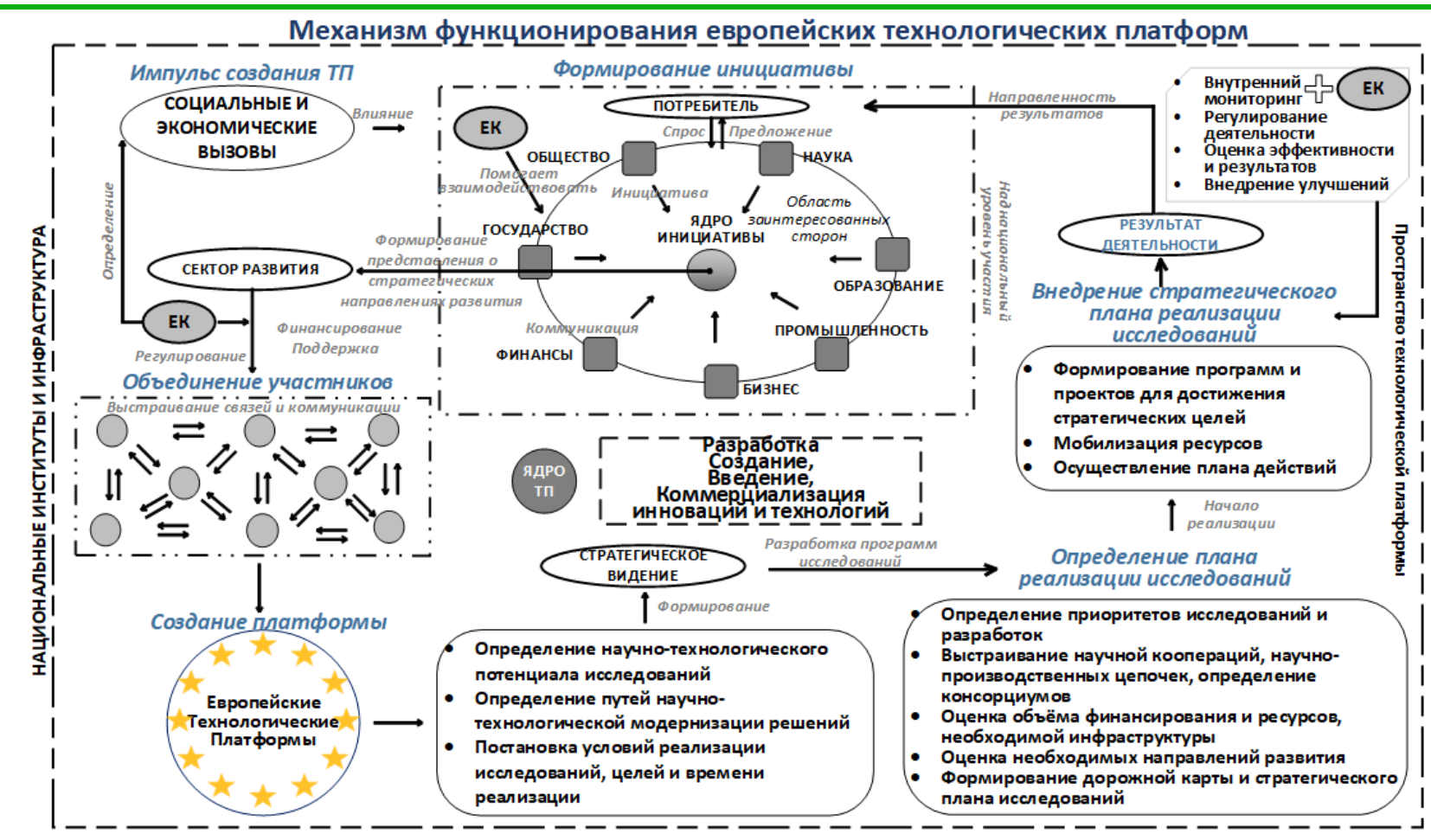

Источник: составлено автором на основе $[13 ; 4 ; 5 ; 14 ; 15 ; 16]$

\section{Рис. 1. Механизм функционирования европейских}

\section{технологических платформ}

По причине того, что платформы в ЕС имеют наднациональный уровень хозяйствования, регулирующим и поддерживающим в запуске платформы органом становится ЕК. Когда инициатива сформирована, подключается ЕК, которая способствует запуску процессов по оформлению и утверждению платформы. Кроме того, ЕК является связующим элементом между участниками платформы и существующими стратегическими программами по инновационно-технологическому развитию. Комиссия также поддерживает научно-исследовательский сектор ТП в реализации инновационного процесса с другими участниками платформы, способствует улучшению координации государственных инвестиций и проводит контроль деятельности ТП, оценивает эффекты и предлагает действия по доработке механизма ЕТП.

Первым фактическим шагом по формированию платформы становится объединение участников, далее утверждение самой платформы. Создание 
платформы предполагает целый ряд мероприятий по оценке имеющегося потенциала, а также целях и путях реализации развития сектора. В результате чего формируется документ, отражающий стратегическое видение развития сектора. После того как выстроена система видений и поставлены необходимые задачи, разрабатываются программы исследований, которые детально описывают приоритеты исследований, финансы и ресурсы, а также поступательные шаги по выполнению поставленных задач. Внедрение стратегического плана исследования означает деятельность платформы, в ходе которой происходит распределение задач и формирование проектов по их реализации и собственно их непосредственное осуществление. Также в ходе деятельности ЕТП проходит постоянный внутренний мониторинг деятельности, к которому подключается контроль и оценка эффективности со стороны ЕК. Результаты деятельности платформы направлены на потребителя.

Организационная структура ЕТП (рис. 2) представляет собой набор органов и групп, которые контролируют, организовывают и реализуют стратегические задачи ЕТП.

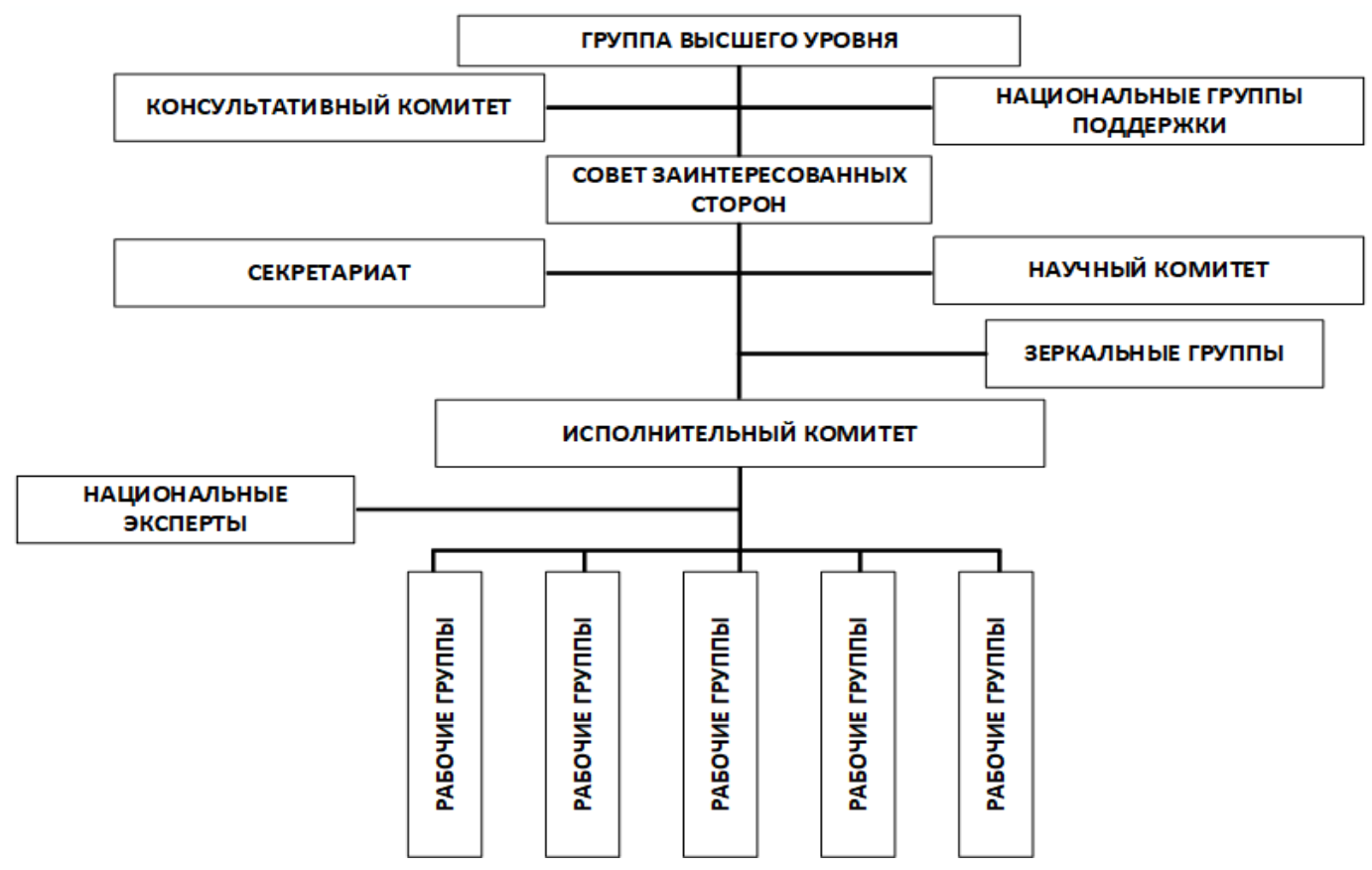

Источник: составлено автором по [17; 5]

\section{Рис. 2. Пример организационной структуры \\ европейской технологической платформы}




\section{СТРАТЕГИЯ НАУЧНО-ТЕХНОЛОГИЧЕСКОГО РАЗВИТИЯ РОССИИ: ПРОБЛЕМЫ И ПЕРСПЕКТИВЫ РЕАЛИЗАЦИИ}

Группа высшего уровня (High Level Group) является инициатором платформы и включает в себя крупный бизнес, отраслевые объединения промышленности, имеющие опыт в коммерциализации результатов исследований и разработок. Для разработки технологической платформы организуется Консультативный комитет (Advisory Committee), в него входят представители ЕК, научного сообщества, малого и среднего бизнеса, организации и объединения потребителей, и др. Параллельно создаются Национальные группы поддержки (National Support Groupe), состоящие из представителей заинтересованных стран и регионов.

Совет заинтересованных сторон (Board of Stakeholders) занимается определением и реализацией целей ТП, утверждает состав участников и принимает все решения связанных с деятельностью ТП. Секретариат (Secretariat) занимается организационным сопровождением деятельности совета заинтересованных сторон, исполнительного комитета, рабочих групп и мероприятий по продвижению платформ.

B Научный совет (Scientific Council) входят эксперты научного сектора ТП, которые представляют прикладные и фундаментальные науки и занимаются проработкой поставленной проблемы исследования с научного ракурса. Зеркальные группы (Mirror Group) обеспечивают взаимодействие технологических платформ с национальными и исследовательскими программами и законодательством стран участников.

Исполнительный комитет (Executive Group) является главным органом управления ТП. Он координирует деятельность ТП, подготавливает и реализует принятые советом заинтересованных сторон решения, представляет ТП на международном уровне, назначает президента платформы. Национальные эксперты (National Experts) оценивают принятые решения и проводят оценку результативности деятельности платформы с учетом ее стратегического плана исследований. Они распространяют информацию о стратегии платформы. Рабочие группы (Working Group) работают над определением направлений и приоритетов исследований и разработок, а также целей в научном и 
промышленном разрезе и мероприятия, которые необходимо реализовать для их достижения.

Перечисленные элементы организационной структуры ТП не имеют обязательного характера, то есть органы, которые не отвечают за контроль и координацию деятельности могут быть выбраны инициаторами платформы в свободном порядке, также могут меняться и названия [17].

В ходе проведенного нами анализа существующих платформ в Евросоюзе, мы выявили, что на сегодняшний момент существует 39 Европейских технологических платформ. Данные платформы охватывают сферы: энергетики, медицины, нано-технологий, обеспечения безопасности, систем интеграции, природопользования, робототехники и другие. Следует сказать, что ЕТП покрывают все приоритетные направления технологического развития в Европе, посредством развития которых экономика может стать конкурентоспособной, способно улучшиться качество жизни населения и могут быть найдены ответы и решения на социальные вызовы.

Пять технологических платформ: Встроенные вычислительные системы ARTEMIS, Европейская инициатива в наноэлектронике ECSEL, Топливные ячейки и водород $\mathrm{FCH}$ JU, Инновационные лекарства IMI, Аэронавтика и воздушный транспорт «Clean Sky 2», которые вышли на новый уровень развития и были переорганизованы в Совместные Технологические Инициативы (СТИ).

СТИ являются специальным механизмом объединения масштабных и обладающих огромным технологическим потенциалом ТП. Главной особенностью данной формы является создание сильного и эффективного координационного механизма реализации инициативы. Их возникновение обусловлено также тем, что ТП имеет возможность сделать рывок к технологическому прорыву, но условий реализации текущего стратегического плана в рамках механизма технологической платформы им уже недостаточно, что требует новой постановки задач и реорганизации с созданием долгосрочных частно-государственных партнерств. СТИ обладают более 


\section{СТРАТЕГИЯ НАУЧНО-ТЕХНОЛОГИЧЕСКОГО РАЗВИТИЯ РОССИИ: ПРОБЛЕМЫ И ПЕРСПЕКТИВЫ РЕАЛИЗАЦИИ}

сложной организационной структурой, с большим числом органов коммуникаций $[18 ; 19 ; 20 ; 21]$.

Несмотря на большой вклад ЕТП и признанную значимость в инновационном и экономическом развитии Европы, существует ряд проблем (рис. 3), возникших с момента их интенсивного запуска. На начальных порах были отмечены ключевые проблемы относительно механизма технологических платформ. Данные проблемы затрагивали коммуникации и участников внутри платформы, организационные моменты и изъяны концепции. Иначе это можно все свести к тому, что были выявлены недостатки в процессе запуска и начального функционирования платформ, которые необходимо было изменить для более синергетического взаимодействия участников, ясности организационного процесса и расширения масштабов платформ в различных аспектах.

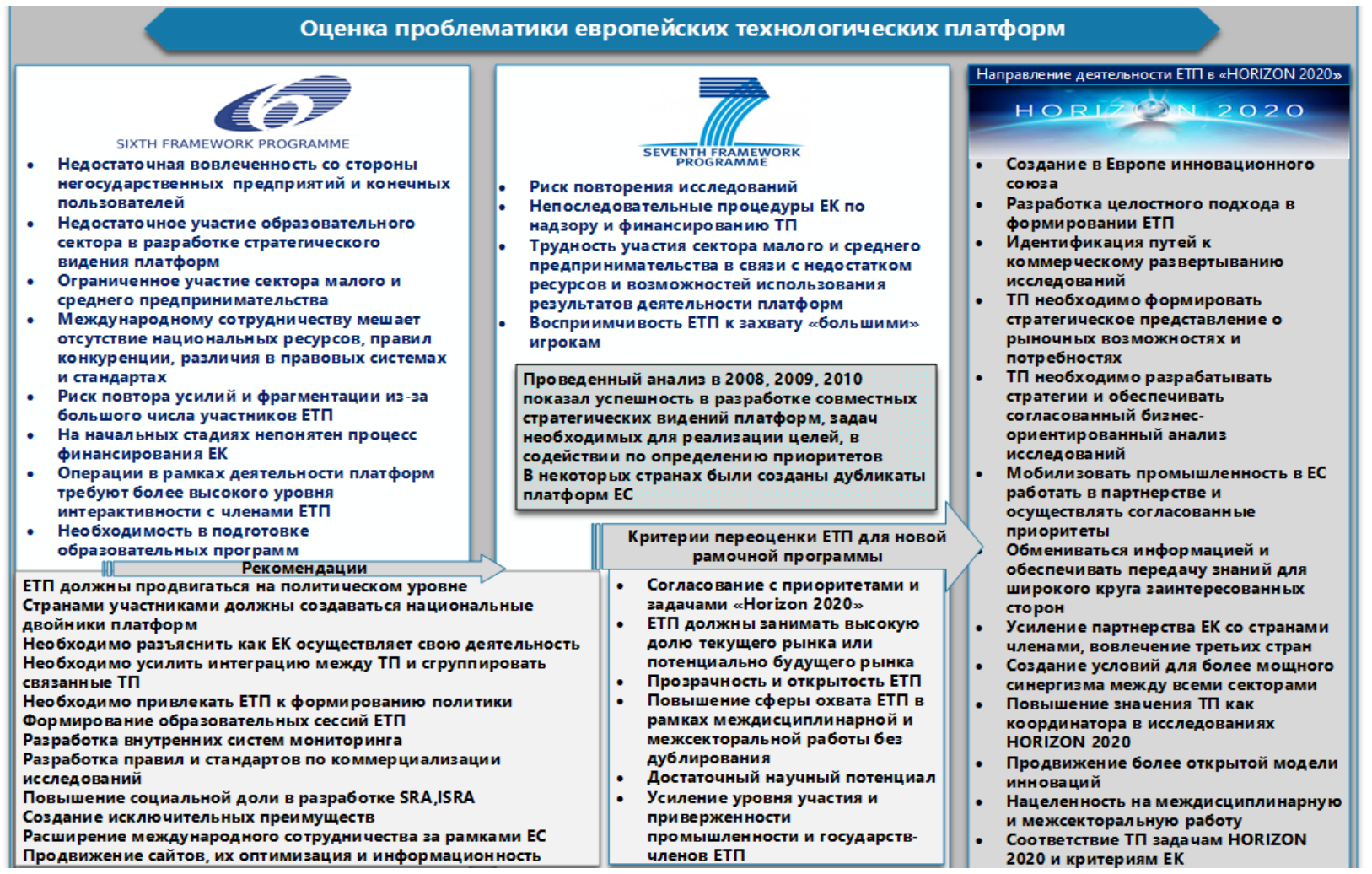

Источник: составлено автором на основании $[8 ; 10 ; 22 ; 5]$

\section{Рис. 3. Оценка проблематики европейских технологических платформ}




\section{СТРАТЕГИЯ НАУЧНО-ТЕХНОЛОГИЧЕСКОГО РАЗВИТИЯ РОССИИ: ПРОБЛЕМЫ И ПЕРСПЕКТИВЫ РЕАЛИЗАЦИИ}

В период седьмой рамочной программы были проведены мероприятия по улучшению ситуации на основе обозначенных проблем и предложенных рекомендаций после оценки периода с 2003 по 2007 год.

Однако, по-прежнему оставались нерешенные вопросы, связанные с риском фрагментации исследований и малой вовлеченностью со стороны малого и среднего предпринимательства, также наблюдались и организационные вопросы, касающиеся надзора и финансирования ЕК.

При формировании плана стратегии развития технологических платформ в рамках 8-ой рамочной программы, концепция ТП и все ключевые проблемы за период существования платформ были пересмотрены еще раз и на их основании были сформированы направления переформатирования работы ТП. Первоначально ЕК были разработаны критерии, по которым проводился анализ существующих платформ. Платформы, соответствующие данным требованиям, официально признавались и продолжали свою деятельность, не соответствующие - не были признаны и переставали входить в состав ЕТП. Таким образом, платформы переориентировали свои цели в соответствии с исследовательскими приоритетами рамочной программы HORIZON 2020.

Кроме того, в нашем исследовании, для доказательства преимущества внедрения технологических платформ, проводим отличительный анализ инструментов инновационно-технологического развития. Нами был отобран ряд инструментов: инновационный кластер, технологическая платформа, технологический парк, научный парк, регион науки, технополис, бизнесинкубатор. Градация инструментов происходит от самых крупных к наиболее ограниченным по масштабам и формам действия. В отборе механизмов инновационного развития территорий, мы руководствовались присутствием в них инновационной составляющей, то есть все инструменты должны были включать объекты создания технологий и их трансфера. В каждом инструменте мы выделяли характерные особенности, преимущества и недостатки, и, кроме того, формировали краткое представление о концепции механизма (табл. 1). 
Таблица 1

\section{Отличительные характеристики инструментов}

инновационно-технологического развития

\begin{tabular}{|c|c|c|c|c|}
\hline $\begin{array}{c}\text { Название } \\
\text { инструмента }\end{array}$ & Описание & Характерная черта & Преимущества & Недостатки \\
\hline $\begin{array}{l}\text { Инновацион- } \\
\text { ный кластер }\end{array}$ & $\begin{array}{l}\text { Предполагает } \\
\text { группу географи- } \\
\text { чески содействую- } \\
\text { щих экономиче- } \\
\text { ских субъектов } \\
\text { обеспечивающх } \\
\text { реализацию пол- } \\
\text { ного инновацион- } \\
\text { ного процесса для } \\
\text { создания производ- } \\
\text { ства по выпуску } \\
\text { долгосрочной кон- } \\
\text { курирующей про- } \\
\text { дукции. Данное } \\
\text { объединение бази- } \\
\text { руется на научно- } \\
\text { исследовательских } \\
\text { и образовательных } \\
\text { центрах, центрах } \\
\text { генераций научных } \\
\text { знаний. }\end{array}$ & $\begin{array}{l}\text { - Оптимизация произ- } \\
\text { водственных процес- } \\
\text { сов. } \\
\text { - Коммерциализация } \\
\text { разработок. } \\
\text { - Развитие региона, в } \\
\text { котором функциони- } \\
\text { рует кластер. } \\
\text { - Повышение уровня } \\
\text { конкурентных пре- } \\
\text { имуществ предприя- } \\
\text { тий. }\end{array}$ & $\begin{array}{l}\text { - Налаженные инфор- } \\
\text { мационные, человече- } \\
\text { ские и финансовые } \\
\text { потоки. } \\
\text { - Гибок к изменениям } \\
\text { внешней среды и к за- } \\
\text { просам рынка. } \\
\text { - Повышенная инве- } \\
\text { стиционная привлека- } \\
\text { тельность. } \\
\text { - Масштабное иннова- } \\
\text { ционное производство. } \\
\text { - Устойчивые связи с } \\
\text { поставщиками и кли- } \\
\text { ентами. }\end{array}$ & $\begin{array}{l}\text { Руководствуется } \\
\text { экономическими } \\
\text { и коммерче- } \\
\text { скими интере- } \\
\text { сами с учетом } \\
\text { того, что данный } \\
\text { вид объединения } \\
\text { является одним } \\
\text { из самых мас- } \\
\text { штабных. }\end{array}$ \\
\hline $\begin{array}{l}\text { Технологиче- } \\
\text { ская плат- } \\
\text { форма }\end{array}$ & $\begin{array}{l}\text { Технологическая } \\
\text { платформа - меха- } \\
\text { низм частно-госу- } \\
\text { дарственного парт- } \\
\text { нерства, направ- } \\
\text { ленный на быстрое } \\
\text { развитие исследо- } \\
\text { ваний и разработок } \\
\text { в пределах отдель- } \\
\text { ных секторов эко- } \\
\text { номики. }\end{array}$ & $\begin{array}{l}\text { Нацелена на решение } \\
\text { социальных и эконо- } \\
\text { мических проблем пу- } \\
\text { тем развертывания } \\
\text { стратегических науч- } \\
\text { ных исследований. }\end{array}$ & $\begin{array}{l}\text { - Осуществляет } \\
\text { коммуникационное } \\
\text { взаимодействие: госу- } \\
\text { дарства, бизнеса, про- } \\
\text { мышленности, универ- } \\
\text { ситетского и финансо- } \\
\text { вого сектора, обще- } \\
\text { ства. } \\
\text { - Открытая, структури- } \\
\text { рованная и гибкая си- } \\
\text { стема, основывающа- } \\
\text { яся на единых принци- } \\
\text { пах } \\
\text { - Реализуется проекты } \\
\text { национального мас- } \\
\text { штаба. }\end{array}$ & $\begin{array}{l}\text { - Сложная сис- } \\
\text { тема начального } \\
\text { финансирования. } \\
\text { - Ограниченное } \\
\text { участие малого и } \\
\text { среднего пред- } \\
\text { принимательства } \\
\text { - Необходимость } \\
\text { высокой степени } \\
\text { интерактивности } \\
\text { участников. }\end{array}$ \\
\hline
\end{tabular}


Продолжение Таблицы 1

\begin{tabular}{|c|c|c|c|c|}
\hline $\begin{array}{l}\text { Технопарки } \\
\text { (отраслевые, } \\
\text { индустриаль- } \\
\text { ные) }\end{array}$ & $\begin{array}{l}\text { Продвижение } \\
\text { внедрения совре- } \\
\text { менных технологий } \\
\text { на уровнях круп- } \\
\text { ных промышлен- } \\
\text { ных комплексов } \\
\text { или производ- } \\
\text { ственных предпри- } \\
\text { ятий с участием } \\
\text { исследовательского } \\
\text {, предпринима- } \\
\text { тельского и адми- } \\
\text { нистративного сек- } \\
\text { тора экономики. }\end{array}$ & $\begin{array}{l}\text { - Направленность на } \\
\text { развитие конкретного } \\
\text { отраслевого направле- } \\
\text { ния, повышение кон- } \\
\text { курентоспособности } \\
\text { промышленности } \\
\text { Разработка наукоемких } \\
\text { технологий }\end{array}$ & $\begin{array}{l}\text { - Развитие } \\
\text { инфраструктуры } \\
\text { - Коммерциализация } \\
\text { разработок и их внед- } \\
\text { рение } \\
\text { Усиливает процессы } \\
\text { интеграции в регионе } \\
\text { между заинтересован- } \\
\text { ными сторонами Ком- } \\
\text { плексное развитие от- } \\
\text { раслей }\end{array}$ & $\begin{array}{l}\text { Региональный } \\
\text { уровень взаимо- } \\
\text { действия }\end{array}$ \\
\hline Научный парк & $\begin{array}{l}\text { Научный парк - } \\
\text { научно-производ- } \\
\text { ственный } \\
\text { территориальный } \\
\text { комплекс, включа- } \\
\text { ющий } \\
\text { в себя исследова- } \\
\text { тельский центр и } \\
\text { примыкающую к } \\
\text { нему компактную } \\
\text { производственную } \\
\text { зону, в которой } \\
\text { на условиях } \\
\text { аренды размеща- } \\
\text { ются малые науко- } \\
\text { емкие фирмы. }\end{array}$ & $\begin{array}{l}\text { Ключевой элемент - } \\
\text { исследовательский } \\
\text { центр. }\end{array}$ & $\begin{array}{l}\text { Стимулирует ускоре- } \\
\text { ние внедрения научно- } \\
\text { технических достиже- } \\
\text { ний, развивает пред- } \\
\text { принимательство и } \\
\text { решает местные соци- } \\
\text { альные проблемы. }\end{array}$ & $\begin{array}{l}\text { - Идеи зачастую } \\
\text { доходят только } \\
\text { до стадии разра- } \\
\text { ботки } \\
\text { - Организация } \\
\text { производства } \\
\text { формируется за } \\
\text { пределами парка. }\end{array}$ \\
\hline Регион науки & $\begin{array}{l}\text { Крупный научно- } \\
\text { производственный } \\
\text { комплекс с разви- } \\
\text { той инфраструкту- } \\
\text { рой сферы обслу- } \\
\text { живания, } \\
\text { охватывающий } \\
\text { значительную } \\
\text { территорию, гра- } \\
\text { ницы которой при- } \\
\text { близительно сов- } \\
\text { падают с админи- } \\
\text { стративными гра- } \\
\text { ницами подразде- } \\
\text { лений типа района } \\
\text { или округа. }\end{array}$ & $\begin{array}{l}\text { Объединяет исследова- } \\
\text { тельские центры, ин- } \\
\text { кубаторы, производ- } \\
\text { ства и малое предпри- } \\
\text { нимательство, государ- } \\
\text { ственные и частные } \\
\text { учреждения для произ- } \\
\text { водства новейшей тех- } \\
\text { нологической продук- } \\
\text { ции. }\end{array}$ & $\begin{array}{l}\text { Развитая сеть комму- } \\
\text { никаций } \\
\text { Взаимодействие раз- } \\
\text { ных представителей } \\
\text { социально-экономиче- } \\
\text { ских групп. }\end{array}$ & $\begin{array}{l}\text { Региональный } \\
\text { уровень взаимо- } \\
\text { действия } \\
\text { Не имеет мас- } \\
\text { штабного кон- } \\
\text { троля и интегри- } \\
\text { рованной орга- } \\
\text { низации дея- } \\
\text { тельности. }\end{array}$ \\
\hline
\end{tabular}


Продолжение Таблицы 1

\begin{tabular}{|c|c|c|c|c|}
\hline Технополисы & $\begin{array}{l}\text { Научно-производ- } \\
\text { ственный комплекс } \\
\text { с развитой инфра- } \\
\text { структурой сферы } \\
\text { обслуживания, } \\
\text { охватывающий } \\
\text { территорию } \\
\text { отдельного города. }\end{array}$ & $\begin{array}{l}\text { Обеспечивает сильную } \\
\text { интеграцию между } \\
\text { объектами генерации } \\
\text { знаний и объектами их } \\
\text { коммерциализации и } \\
\text { производства. }\end{array}$ & $\begin{array}{l}\text { Направленность на } \\
\text { коммерциализацию } \\
\text { разработок. }\end{array}$ & $\begin{array}{l}\text { Не ориентирован } \\
\text { на решение со- } \\
\text { циальных про- } \\
\text { блем. }\end{array}$ \\
\hline $\begin{array}{l}\text { Бизнес-инку- } \\
\text { батор }\end{array}$ & $\begin{array}{l}\text { Площадка, на ко- } \\
\text { торой создаются } \\
\text { все необходимые } \\
\text { условия для за- } \\
\text { пуска и развития } \\
\text { малых инноваци- } \\
\text { онных компаний. }\end{array}$ & $\begin{array}{l}\text { Инструмент развития и } \\
\text { поддержки малого и } \\
\text { среднего предприни- } \\
\text { мательства }\end{array}$ & $\begin{array}{l}\text { - Отбор компаний с } \\
\text { перспективными } \\
\text { направлениями дея- } \\
\text { тельности. } \\
\text { - Финансирование } \\
\text { исследований. } \\
\text { Повышение инвести- } \\
\text { ционной привлека- } \\
\text { тельности региона в } \\
\text { предпринимательство. }\end{array}$ & $\begin{array}{l}\text { - Имеет времен- } \\
\text { ное ограничение } \\
\text { для компаний. } \\
\text { Носит регио- } \\
\text { нальный харак- } \\
\text { тер. }\end{array}$ \\
\hline
\end{tabular}

Источник: составлено автором

Основываясь на полученных результатах, мы хотим отметить, что инструменты имеют различную конечную направленность своей деятельности и ее масштаб. В итоге выбранные инструменты можно разделить на две группы, объединив их по схожим характеристикам. В первую группу входят инструменты более масштабного характера, во вторую - инструменты локального уровня (табл. 2). Рассмотрим инструменты инновационного развития, максимально приближенные к технологическим платформам. К ним относятся кластеры, технопарки, регион науки.

Кластерный подход актуален и весьма эффективен в части повышения конкурентоспособности экономики региона, обеспечения инфраструктурой и коммерциализации результатов НИОКР. Данная форма взаимодействия обеспечивает высокий уровень интеграции участников и повышает инвестиционную привлекательность субъектов взаимодействия. Однако конечной целью данного объединения является коммерциализация разработок. 
Таблица 2

Группы инструментов инновационного развития

\begin{tabular}{|c|l|l|}
\hline Группа & \multicolumn{1}{|c|}{ Характеристика группы } & \multicolumn{1}{c|}{\begin{tabular}{c}
\multicolumn{1}{|c|}{ Инструменты инновационного } \\
развия
\end{tabular}} \\
\hline 1 группа & $\begin{array}{l}\text { Масштабные объединения, } \\
\text { реализующие генерацию и трансфер } \\
\text { наукоемких технологий }\end{array}$ & $\begin{array}{l}\text { Инновационный кластер, } \\
\text { технологическая платформа, } \\
\text { технопарк, регион науки }\end{array}$ \\
\hline 2 группа & $\begin{array}{l}\text { Менее крупные объединения, } \\
\text { с ориентированностью на } \\
\text { региональный уровень }\end{array}$ & $\begin{array}{l}\text { Технополис, научный парк, бизнес- } \\
\text { инкубатор }\end{array}$ \\
\hline
\end{tabular}

Источник: составлено автором

Технопарки определяют себя как единицы инновационного кластера и направлены на комплексное развитие отраслей и производств через разработку и трансфер технологий. Регионы науки являются инструментом коммуникации различных социально-экономических секторов. Территория региона направлена на научно-технологическое развитие.

Выделяются на фоне перечисленных инструментов инновационнотехнологического развития технологические платформы. Данная форма взаимодействия может носить, как региональный, так и национальный или наднациональный характер. Такое объединение действует в целях разработки перспективных направлений стратегического развития, a также их основополагающим мотивом является решение социально-экономических проблем. Технологические платформы объединяют не только бизнес, промышленность, науку, образование, но и общественный и государственный сектор. Ключевым звеном технологической платформы является разработка направлений исследований путем настраивания коммуникаций секторов экономики и общества. 


\section{СТРАТЕГИЯ НАУЧНО-ТЕХНОЛОГИЧЕСКОГО РАЗВИТИЯ РОССИИ: ПРОБЛЕМЫ И ПЕРСПЕКТИВЫ РЕАЛИЗАЦИИ}

Технологические платформы реализуют междисциплинарные и межсекторальные исследования, что в отраслевом развитии имеет важную роль. Этот фактор не так акцентирован и проявляется в других формах взаимодействия. Технологические платформы имеют структуру и порядок формирования. Инициатива исходит от частного сектора, но, тем не менее, технологические платформы находятся под наблюдением и контролем государства, а также они ощущают колоссальную финансовую поддержку в рамках национальных программ.

Аккумулируя перечисленные аргументы, следует сделать вывод, что ТП являются оптимальным инструментом инновационно-технологического развития, так как реализуют разработку перспективных исследований при привлечении максимального количества заинтересованных сторон для повышения конкурентоспособности экономики, качества жизни населения посредством решения глобальных социальных и экономических вызовов.

\section{2 Анализ использования технологических платформ в мире}

Рассмотрим использование концепции технологических платформ в других странах с разным уровнем прогресса в продвижении технологических платформ, за исключением стран ЕС (Турция, Белоруссия, Евразийских технологических платформ и России).

Похожим феноменом интеграции стран по механизму ТП на наднациональном уровне стали евразийские технологические платформы. Стоит отметить, что это первое наднациональное объединение по форме ТП после Евросоюза. Текущее положение евразийских платформ представлено на рис. 4.

Евразийские технологические платформы объединяют следующие страны: Россия, Армения, Беларусь, Казахстан, Киргизия. 


\section{СТРАТЕГИЯ НАУЧНО-ТЕХНОЛОГИЧЕСКОГО РАЗВИТИЯ РОССИИ: ПРОБЛЕМЫ И ПЕРСПЕКТИВЫ РЕАЛИЗАЦИИ}

Идея о формировании платформ была выдвинута в 2013 году Евразийской экономической комиссией. Работа в целях создания общих технологических платформ начата относительно недавно. В марте 2017 года вступило распоряжение совета Евразийского экономического союза о формировании приоритетных евразийских платформ.

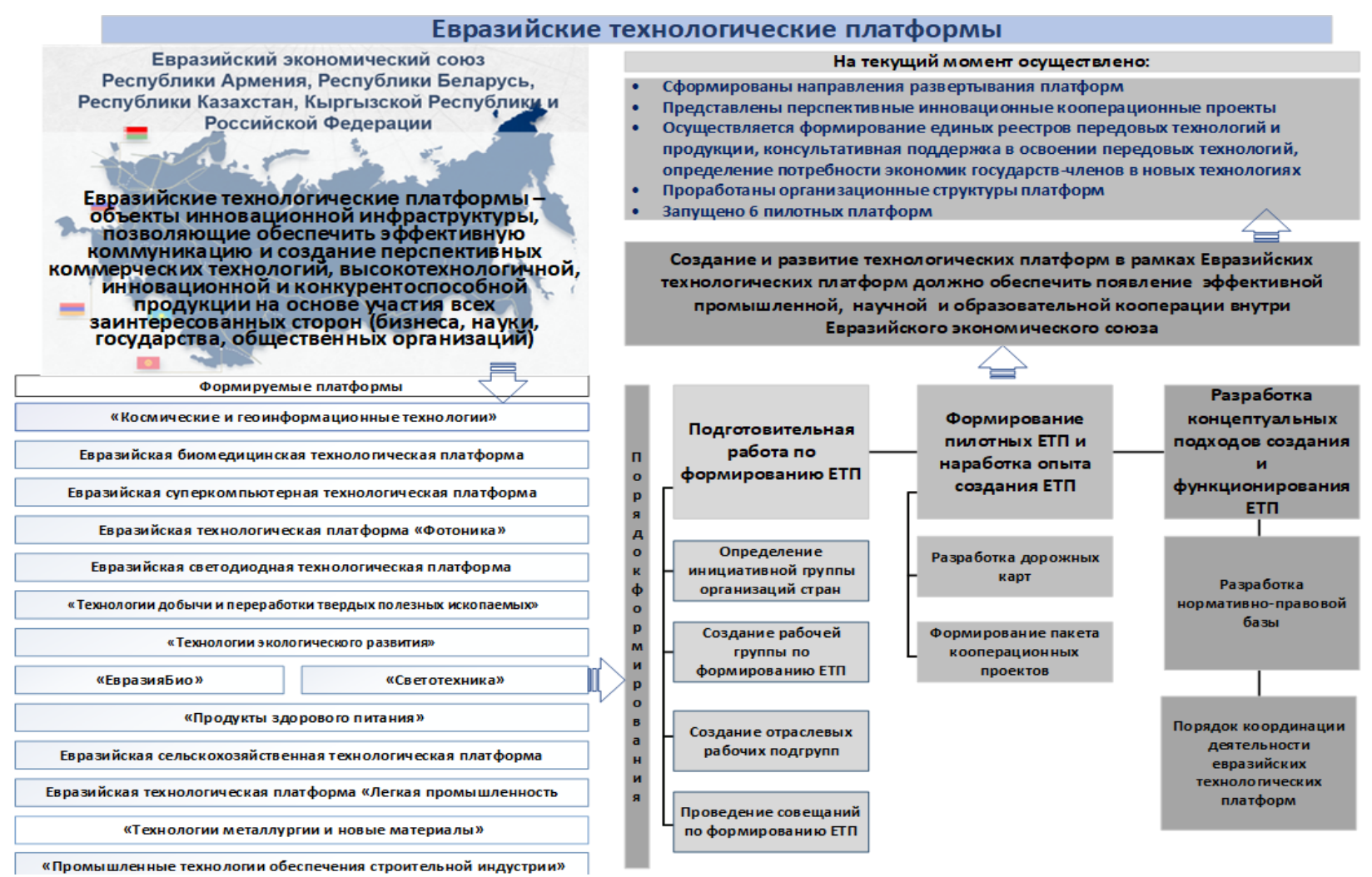

Источник: составлено автором на основе [25; 26; 23; 24]

\section{Рис. 4. Положение евразийских технологических платформ}

Поскольку процесс формирования находится на начальном этапе, на данный момент обозначены приоритетные направления их создания и организуется мероприятия по их содержательному наполнению и запуску. До сих пор не обозначен процесс регулирования и руководства со стороны государств союза, однако инициатива отражает государственный интерес на международном уровне и уже сейчас четко выражен со стороны всех государств. На наш взгляд, так как Россия является лидером в данном союзе по 
опыту внедрения платформ, то нами предполагается, что будет проводиться идентичная России система выстраивания концепции формирования ТП. На данный момент сформировано 9 платформ, где утверждены координирующие, руководствующие органы платформы. Активно проводится продвижение созданных платформ, разработка дорожных карт. Разработана нормативно-правовая база концепции [23; 24].

В Белоруссии стратегия инновационного развития, продвигает национальные технологические платформы, которые формировались на основе европейского и российского опыта. Цель создания платформ в Белоруссии предполагает выработку общего видения развития существующих отраслей и проработку программы необходимых действий для их инновационнотехнологического развития.

Сейчас в стране существуют платформы в следующих специализациях: нанотехнологии, медицина, биоиндустрия и биоресурсы, фотоника. Особое внимание привлекают технологические платформы в области нанотехнологий. Интерес к ним вызывает особый подход развития данной отрасли, предполагающий разработку сети национальных нанотехнологических платформ, которые представлены девятью нанотехнологическими платформами с акцентом на разные объекты исследования. Данный подход позволяет проводить конкретные исследования в поле деятельности платформ и исключить фрагментарность, повторений исследований, что способствует большему охвату и глубины изучения сектора. Регулирование платформ находится под контролем государства, однако большую роль в принятии управленческих и стратегических решений принимает Межведомственный координационный совет по развитию наноиндустрии в Республике Беларусь и Республиканская ассоциация наноиндустрии. Остальные направления платформ формировались в соответствии с приоритетными направлениями развития российских технологических платформ. 


\section{СТРАТЕГИЯ НАУЧНО-ТЕХНОЛОГИЧЕСКОГО РАЗВИТИЯ РОССИИ: ПРОБЛЕМЫ И ПЕРСПЕКТИВЫ РЕАЛИЗАЦИИ}

В Турции отмечается сильная направленность усилий правительства на создание инновационной системы страны и, также особое внимание по средствам осуществления стратегии инновационного развития уделяется технологическим платформам. Вопросами формирования и продвижения концепции технологических платформ в стране занимается Совет по науке и технологиям Турции совместно с министерствами отраслевого направления платформ.

Платформы начали формироваться с 2008 года, целью их создания стало увеличение научно-исследовательского и инновационного потенциала промышленности. Созданные в Турции технологические платформы охватывают сферы электрики, электроники, металла, текстиля, морских наук, автомобилей, энергии и фармацевтики [27; 28].

Для того чтобы наиболее точно понять принцип формирования турецких технологических платформ, мы изучили опыт создания турецкой строительной технологической платформы, которая была учреждена в 2006 году в рамках проведения череды семинаров и встреч представителей строительного сектора Турции. Первый семинар был организован Палатой архитекторов Турции при поддержке Европейской программы «ENABLE» для создания технологических платформ. На семинаре присутствовали государственные представители Министерства общественного благоустройства и расселения, Совета по научнотехническим исследованиям Турции, университеты, учреждения, работающие для установления отношений между производителями и пользователями строительной индустрии, такие как Информационный центр по строительству, профессиональные организации: Ассоциация турецких инженеровконсультантов и архитекторов и Палата гражданских инженеров Турции, объединения производителей строительных материалов, представители строительных промышленников. В результате оценки потенциала и возможностей сектора было принято развивать сектор в инновационнотехнологическом направлении и учредить платформу [29; 30]. 
Опыт внедрения показывает, что формирование платформ в Турции опиралось на европейский опыт, и инициатива была выдвинута объединением всех представителей заинтересованных сторон в развитии строительного сектора, что показывает единство цели единомышленников и отсутствие проблемы настраивания коммуникации. Однако в отношении структуры платформы наблюдается отсутствие ее четкой проработанности. Так на официальном сайте платформы отсутствует организационная структура, перечень стейкхолдеров и документы о стратегическом развитии платформы. Кроме того, Турция является активным участником ЕТП, что также способствует повышению инновационному потенциалу Турции и реализации долгосрочных и среднесрочных стратегий.

Результаты исследования технологических платформ Евразийского экономического союза, Турции, Белоруссии (табл. 3).

Таблица 3

Применение концепции технологических платформ в Турции, Белоруссии и Евразийском экономическом союзе

\begin{tabular}{|c|c|c|c|c|c|c|}
\hline $\begin{array}{c}\text { Стра } \\
\text { на, } \\
\text { год } \\
\text { со- } \\
\text { зда- } \\
\text { ния }\end{array}$ & $\begin{array}{c}\text { Опреде- } \\
\text { ление }\end{array}$ & Цель & $\begin{array}{c}\text { Ко- } \\
\text { личе- } \\
\text { ство }\end{array}$ & Примеры платформ & Характеристика & Сферы ТП \\
\hline $\begin{array}{l}\text { Тур- } \\
\text { ция } \\
2008\end{array}$ & $\begin{array}{l}\text { Анало- } \\
\text { гично } \\
\text { опреде- } \\
\text { лению } \\
\text { Евро- } \\
\text { пейского } \\
\text { Союза }\end{array}$ & $\begin{array}{l}\text { Созданы с це- } \\
\text { лью увеличе- } \\
\text { ния } \\
\text { научно-иссле- } \\
\text { довательского } \\
\text { и инновацион- } \\
\text { ного потенци- } \\
\text { ала промыш- } \\
\text { ленности, по- } \\
\text { вышения ком- } \\
\text { петенции в } \\
\text { области иссле- } \\
\text { дований, тех- } \\
\text { нологических } \\
\text { разработок и } \\
\text { инноваций. }\end{array}$ & $* 5+$ & $\begin{array}{l}\text { - Turkish Construction } \\
\text { Technology Platform; } \\
\text { - Automotive Technol- } \\
\text { ogy Platform; } \\
\text { - TOBB BIO; } \\
\text { - National Food Tech- } \\
\text { nology Platform; } \\
\text { - Turkish Mechanical } \\
\text { Industry Platform. }\end{array}$ & $\begin{array}{l}\text { Турецкие плат- } \\
\text { формы функциони- } \\
\text { руют не только на } \\
\text { национальном } \\
\text { уровне, но и неко- } \\
\text { торые из них явля- } \\
\text { ются дубликатом } \\
\text { Европейских техно- } \\
\text { логических плат- } \\
\text { форм, участником } \\
\text { которых является } \\
\text { Турция. } \\
\text { Разработка страте- } \\
\text { гических направле- } \\
\text { ний деятельности } \\
\text { платформ организу- } \\
\text { ется при поддержке } \\
\text { различных мини- } \\
\text { стерств, организа- } \\
\text { ций и ассоциаций } \\
\text { выбранного сектора } \\
\text { платформ. }\end{array}$ & $\begin{array}{l}\text { Электрика, } \\
\text { электрони- } \\
\text { ка, металл, } \\
\text { текстиль, } \\
\text { морские } \\
\text { науки, ав- } \\
\text { томобили, } \\
\text { энергия } \\
\text { и фарма- } \\
\text { цевтика }\end{array}$ \\
\hline
\end{tabular}


Продолжение Таблицы 3

\begin{tabular}{|c|c|c|c|c|c|c|}
\hline $\begin{array}{l}\text { Бела- } \\
\text { русь } \\
2013\end{array}$ & $\begin{array}{l}\text { Анало- } \\
\text { гично } \\
\text { опреде- } \\
\text { лению } \\
\text { Россий- } \\
\text { ской } \\
\text { Федера- } \\
\text { ции }\end{array}$ & $\begin{array}{l}\text { Вырабатывают } \\
\text { общее видение } \\
\text { будущего раз- } \\
\text { вития соответ- } \\
\text { ствую- } \\
\text { щей отрасли, } \\
\text { формируют и } \\
\text { реа- } \\
\text { лизуют необ- } \\
\text { ходимую про- } \\
\text { грамму дей- } \\
\text { ствий. }\end{array}$ & $* 9+$ & $\begin{array}{l}\text { - Сеть национальных } \\
\text { нанотехнологических } \\
\text { платформ: } \\
\text { - Нанотехнологиче- } \\
\text { ская платформа по } \\
\text { наноструктурам из ме- } \\
\text { таллов, полупроводни- } \\
\text { ков и диэлектриков (на } \\
\text { базе БГУИР); } \\
\text { - Нанотехнологиче- } \\
\text { ская платформа по ма- } \\
\text { териалам и структурам } \\
\text { нанофотоники (на базе } \\
\text { Института физики } \\
\text { НАН Беларуси) Нано- } \\
\text { технологическая плат- } \\
\text { форма по углеродным } \\
\text { наноструктурам (на } \\
\text { базе ИТМО } \\
\text { НАН Беларуси); } \\
\text { - Нанотехнологиче- } \\
\text { ская платформа по ска- } \\
\text { нирующим зондовым } \\
\text { технологиям (на базе } \\
\text { ИТМО НАН Беларуси } \\
\text { и БНТУ); } \\
\text { - Нанотехнологиче- } \\
\text { ская платформа по } \\
\text { магнитным материалам } \\
\text { (на базе Центра по ма- } \\
\text { териаловедению НАН } \\
\text { Беларуси); } \\
\text { - Нанотехнологиче- } \\
\text { ская платформа по } \\
\text { биологическим нано- } \\
\text { структурам (на базе } \\
\text { БГУ); } \\
\text { - Нанотехнологиче- } \\
\text { ская платформа по ме- } \\
\text { дицине и фармацевтике } \\
\text { (на базе медицинского } \\
\text { университета); } \\
\text { - Нанотехнологиче- } \\
\text { ская платформа по кон- } \\
\text { струкционным поли- } \\
\text { мерным нанокомпози- } \\
\text { там (на базе ИММС } \\
\text { НАН Беларуси с уча- } \\
\text { стием ИХНМ НАНуси;) } \\
\text { - Нанотехнологическая } \\
\text { платформа по строи- } \\
\text { тельным материалам } \\
\text { (на базе БНТу). }\end{array}$ & $\begin{array}{l}\text { Ориентируются на } \\
\text { направления фор- } \\
\text { мирования плат- } \\
\text { форм в России. } \\
\text { Каждая платформа } \\
\text { должна представ- } \\
\text { лять собой научно- } \\
\text { учебно-производ- } \\
\text { ственный центр, } \\
\text { оснащенный совре- } \\
\text { менным технологи- } \\
\text { ческим и аналити- } \\
\text { ческим оборудова- } \\
\text { нием по профилю } \\
\text { своей деятельности. } \\
\text { Основными } \\
\text { функциями плат- } \\
\text { формы являются: } \\
\text { - аналитическое и } \\
\text { технологическое } \\
\text { обеспечение } \\
\text { научных исследова- } \\
\text { ний по актуальным } \\
\text { направлениям раз- } \\
\text { вития нанотехноло- } \\
\text { гий и создания } \\
\text { наноматериалов; } \\
\text { - научное обеспече- } \\
\text { ние освоения в про- } \\
\text { изводстве нанотех- } \\
\text { нологий и нанома- } \\
\text { териалов; } \\
\text { - подготовка инже- } \\
\text { нерных и научных } \\
\text { кадров в области } \\
\text { нанотехнологий и } \\
\text { наноматериалов; } \\
\text { - консалтинг. } \\
\text { Особенность в рас- } \\
\text { ширенном спектре } \\
\text { ориентации ком- } \\
\text { мерциализации раз- } \\
\text { работок. }\end{array}$ & $\begin{array}{l}\text { Нанотехно- } \\
\text { логии, ме- } \\
\text { дицина, } \\
\text { биоинду- } \\
\text { стрия и } \\
\text { биоресурсы, } \\
\text { фотоника }\end{array}$ \\
\hline
\end{tabular}


Продолжение Таблицы 3

\begin{tabular}{|c|c|c|c|c|c|c|}
\hline $\begin{array}{l}\text { ск } \\
\text { пл } \\
\text { фо } \\
\text { мь } \\
20\end{array}$ & $\begin{array}{l}\text { Евразий- } \\
\text { ские } \\
\text { техноло- } \\
\text { гические } \\
\text { плат- } \\
\text { формы - } \\
\text { объекты } \\
\text { иннова- } \\
\text { ционной } \\
\text { инфра- } \\
\text { струк- } \\
\text { туры, } \\
\text { позво- } \\
\text { ляющие } \\
\text { обеспе- } \\
\text { чить } \\
\text { эффек- } \\
\text { тивную } \\
\text { комму- } \\
\text { никацию } \\
\text { и созда- } \\
\text { ние пер- } \\
\text { спек- } \\
\text { тивных } \\
\text { коммер- } \\
\text { ческих } \\
\text { техноло- } \\
\text { гий, вы- } \\
\text { сокотех- } \\
\text { ноло- } \\
\text { гичной, } \\
\text { иннова- } \\
\text { ционной } \\
\text { и конку- } \\
\text { ренто- } \\
\text { способ- } \\
\text { ной про- } \\
\text { дукции на } \\
\text { основе } \\
\text { участия } \\
\text { всех } \\
\text { заинте- } \\
\text { ресован- } \\
\text { ных сто- } \\
\text { рон } \\
\text { (бизнеса, } \\
\text { науки, } \\
\text { государ- } \\
\text { ства, } \\
\text { обще- } \\
\text { ственных } \\
\text { организа- } \\
\text { ций }\end{array}$ & $\begin{array}{l}\text { В целях созда- } \\
\text { ния центров } \\
\text { компетенций в } \\
\text { государствах- } \\
\text { членах, для } \\
\text { формирования } \\
\text { экономики } \\
\text { будущего, } \\
\text { постоянного } \\
\text { технологиче- } \\
\text { ского обновле- } \\
\text { ния, повыше- } \\
\text { ния глобальной } \\
\text { конкуренто- } \\
\text { способности } \\
\text { промышленно- } \\
\text { сти. }\end{array}$ & 14 & $\begin{array}{l}\text { - Евразийская } \\
\text { технологическая платформа } \\
\text { «Космические и } \\
\text { геоинформационные } \\
\text { технологии; } \\
\text { - Евразийская биоме- } \\
\text { дицинская технологическая } \\
\text { платформа; } \\
\text { - Евразийская супер- } \\
\text { компьютерная техноло- } \\
\text { гическая платформа; } \\
\text { - Евразийская } \\
\text { технологическая платформа } \\
\text { «Фотоника»; } \\
\text { - Евразийская светодиодная } \\
\text { технологическая платформа; } \\
\text { - Евразийская } \\
\text { технологическая платформа } \\
\text { «Технологии добычи и } \\
\text { переработки твердых } \\
\text { полезных ископаемых»; } \\
\text { - Евразийская } \\
\text { технологическая платформа } \\
\text { «Технологии экологического } \\
\text { развития»; } \\
\text { - Евразийская } \\
\text { технологическая платформа } \\
\text { «ЕвразияБио»; } \\
\text { - Евразийская } \\
\text { технологическая платформа } \\
\text { «Технологии пищевой и } \\
\text { перерабатывающей } \\
\text { промышленности } \\
\text { агропромышленного } \\
\text { комплекса - продукты } \\
\text { здорового питания»; } \\
\text { - Евразийская } \\
\text { сельскохозяйственная } \\
\text { технологическая платформа } \\
\text { Евразийская технологическая } \\
\text { платформа «Легкая } \\
\text { промышленность»; } \\
\text { - Евразийская } \\
\text { технологическая платформа } \\
\text { «Технологии металлургии и } \\
\text { новые материалы»; } \\
\text { - Евразийская } \\
\text { технологическая платформа } \\
\text { «Промышленные технологии } \\
\text { обеспечения строительной } \\
\text { индустрии»; } \\
\text { - Светотехника. }\end{array}$ & $\begin{array}{l}\text { Обеспечение } \\
\text { системной } \\
\text { работы по } \\
\text { аккумулирован } \\
\text { ию передовых } \\
\text { национальных } \\
\text { и мировых } \\
\text { достижений } \\
\text { научно- } \\
\text { технического } \\
\text { развития, } \\
\text { мобилизации } \\
\text { научного } \\
\text { потенциала } \\
\text { государств- } \\
\text { членов для } \\
\text { решения } \\
\text { прикладных } \\
\text { задач по } \\
\text { разработке } \\
\text { инновационных } \\
\text { продуктов и } \\
\text { технологий, а } \\
\text { также их } \\
\text { внедрению в } \\
\text { промышленное } \\
\text { производство. }\end{array}$ & $\begin{array}{l}\text { Космиче- } \\
\text { ские и гео- } \\
\text { информа- } \\
\text { ционные } \\
\text { технологии, } \\
\text { биомеди- } \\
\text { цина, ком- } \\
\text { пьютерные } \\
\text { технологии, } \\
\text { фотоника, } \\
\text { экология, } \\
\text { оптические } \\
\text { технологии, } \\
\text { обработки } \\
\text { твердых } \\
\text { полезных } \\
\text { ископаемых } \\
\text { и биотехно- } \\
\text { логии, сель- } \\
\text { скохозяй- } \\
\text { ственные } \\
\text { технологии, } \\
\text { светотех- } \\
\text { ники, стро- } \\
\text { ительства и } \\
\text { др. }\end{array}$ \\
\hline
\end{tabular}

*отсутствует информация о полном перечне платформ

Источник: составлено автором по [25; 26; 24; 23; 27; 28; 30; 29] 


\section{СТРАТЕГИЯ НАУЧНО-ТЕХНОЛОГИЧЕСКОГО РАЗВИТИЯ РОССИИ: ПРОБЛЕМЫ И ПЕРСПЕКТИВЫ РЕАЛИЗАЦИИ}

Идея о создании технологических платформ в России впервые была заложена в Концепцию долгосрочного социально-экономического развития РФ на период до 2020 года, выпущенная в 2008 году. В ней правительство расценивает инструмент ТП как одно из средств достижений целей стратегии. Следующим шагом развития идеи технологических платформ был выпуск реферата Общественной палаты РФ с целью построения рекомендаций по определению наиболее перспективных направлений платформ и методологии по формированию и функционированию ТП в России, который практически остался без внимания. Впервые прочное положение технологических платформ было закреплено в Стратегии инновационного развития России в период до 2020 года, где были уточнены пошаговые меры становления концепции ТП $[31 ; 32 ; 33]$.

При формировании концептуального подхода запуска российских технологических платформ, Минэкономразвития придерживалось общего подхода, основанного на изучении опыта европейских платформ. При адаптации ТП были изменены в части последовательности формирования инициативы и их практического назначения. Сущность ТП в России стала обозначаться следующим образом: «коммуникационный инструмент, направленный на активизацию усилий по созданию перспективных коммерческих технологий, новых продуктов (услуг), на привлечение дополнительных ресурсов для проведения исследований и разработок на основе участия всех заинтересованных сторон (бизнеса, науки, государства, гражданского общества), совершенствование нормативно-правовой базы в области научно-технологического, инновационного развития».

Внедрение подобного инструмента правительством России предполагало заполнение ряда пустот в целом по инновационно-технологическому развитию страны, в частности в НИОКР и бизнес-секторе России: неясность интересов бизнеса, низкий уровень коммуникационного взаимодействия между 
представителями различных экономических и социальных секторов, фрагментарность, неоднородность исследований и проблемы коммерциализации результатов исследования, отсутствие качественных и эффективных инструментов инновационно-технологического развития.

Основными задачами российских технологических платформ стало:

- вовлечение бизнес-сектора и общества в процесс разработки и реализации направлений научно-технологического развития;

- поиск возможностей модернизации экономики;

- обеспечение новыми стандартами и средствами трансфера технологий;

- стимулирование инноваций и инновационной активности бизнеса;

- расширение кооперации между заинтересованными сторонами платформ в инновационной сфере;

- продвижение и коммерциализация результатов НИОКР.

Процесс запуска формирования платформ, начался параллельно с разработкой стратегии инновационного развития. Так в 2010 году был запущен прием заявок с последующим отбором перспективных направлений платформ, затем последовал второй призыв заявок, поскольку было необходимо привлечь крупные промышленные компании. В первом случае было создано 27 платформ, а уже в 2012 году - 30, где также был представлен новый перечень ТП с более детально проработанной структурой содержания направлений исследований.

В 2018 году Минэкономразвития России предоставило обзор о российских технологических платформах, где фигурируют уже 36 технологических платформ, осуществляющих свою деятельность по 13 самым приоритетным и перспективным направлениям инновационнотехнологического развития, определенных на текущий момент. Российские технологические платформы на 2018 год представлены в табл. 4 [34]. 
Таблица 4

\section{Перечень российских технологических платформ}

\begin{tabular}{|c|c|c|}
\hline Название платформы & Год основания & Регион \\
\hline Медицина будущего & 2011 & Томская область \\
\hline Биотех2030 & 2012 & Москва \\
\hline Биоэнергетика & 2010 & Москва \\
\hline Национальная суперкомпьютерная технологическая платформа & 2011 & Москва \\
\hline $\begin{array}{l}\text { Инновационные лазерные, оптические оптоэлектронные технологии } \\
\text { - фотоника }\end{array}$ & 2011 & Москва \\
\hline Развитие российских светодиодных технологий & 2011 & Москва \\
\hline Авиационная мобильность и авиационные технологии & 2010 & Московская обл. \\
\hline Национальная космическая технологическая платформа & 2011 & Москва \\
\hline Национальная информационная спутниковая система & 2011 & Красноярский край \\
\hline $\begin{array}{l}\text { Замкнутый ядерный топливный цикл с реакторами на быстрых } \\
\text { нейтронах }\end{array}$ & 2011 & Москва \\
\hline Управляемый термоядерный синтез & 2011 & Москва \\
\hline Радиационные технологии & 2011 & Москва \\
\hline Интеллектуальная энергетическая система России & 2010 & Москва \\
\hline Экологическая чистая тепловая энергетика высокой эффективности & 2011 & Москва \\
\hline Перспективные технологии возобновляемой энергетики & 2010 & Москва \\
\hline Малая распределенная энергетика & 2011 & Москва \\
\hline Новые полимерные композиционные материалы и технологии & 2011 & Москва \\
\hline Материалы и технологии металлургии & 2013 & Москва \\
\hline Технологическая платформа твердых полезных ископаемых & 2013 & Москва \\
\hline Технологии добычи и использования углеводородов & 2011 & Москва \\
\hline Глубокая переработка углеводородных ресурсов & 2011 & Москва \\
\hline $\begin{array}{l}\text { Технологии мехатроники, встраиваемых систем управления, } \\
\text { радиочастотной идентификации и роботостроение }\end{array}$ & 2011 & Москва \\
\hline СВЧ технологии & 2011 & Москва \\
\hline Освоение Океана & 2011 & $\begin{array}{l}\text { Оформляется } \\
\text { на территории } \\
\text { Приморского края } \\
\end{array}$ \\
\hline Технологии экологического развития & 2011 & Москва \\
\hline $\begin{array}{l}\text { Моделирование и технологии эксплуатации } \\
\text { высокотехнологических систем (промышленность будущего) }\end{array}$ & 2011 & Москва \\
\hline Текстильная и легкая промышленность & 2012 & $\begin{array}{l}\text { Республика } \\
\text { Татарстан }\end{array}$ \\
\hline Экологически чистый транспорт «зеленый автомобиль» & 2012 & Москва \\
\hline $\begin{array}{l}\text { Технологии пищевой и перерабатывающей промышленности АПК } \\
\text { - продукты здорового питания }\end{array}$ & 2012 & $\begin{array}{l}\text { Воронежская } \\
\text { область }\end{array}$ \\
\hline Легкие и надежные конструкции & 2012 & Московская область \\
\hline Комплексная безопасность промышленности и энергетики & 2011 & Москва \\
\hline Строительство и архитектура & 2014 & Москва \\
\hline $\begin{array}{l}\text { Использование результатов космической деятельности в интересах } \\
\text { конечных потребителей }\end{array}$ & 2016 & Москва \\
\hline Инновационные машинные технологии сельского хозяйства & 2016 & Москва \\
\hline Национальная программная платформа & 2010 & Москва \\
\hline Высокоскоростной интеллектуальный железнодорожный транспорт & 2010 & Москва \\
\hline
\end{tabular}

Источник: составлено автором по [34] 
На текущий момент одним из главных этапов развития российских технологических платформ является формирование евразийских технологических платформ, поскольку одно из видений их создания предполагает продолжение развертывания данной структуры в России. Данное действие предполагает выход платформ на новый уровень развития.

Россия также является участником ЕТП. Платформы, в которых принимается участие, обозначены в российском платформенном пространстве, которые также учитывают в целом российские и евразийские платформы. Российское платформенное пространство представлено на рис. 5.

Географически основная концентрация технологических платформ приходится на Москву и Московскую область. На Дальнем Востоке существует одна технологическая платформа «Освоение океана», созданная в 2011 году в Приморском крае. Платформа охватывает 4 технологических направления: технологии морских роботизированных систем, технологии освоения природных ресурсов Мирового океана, информационные технологии и системы для освоения Мирового океана, технологии создания морской техники [35].

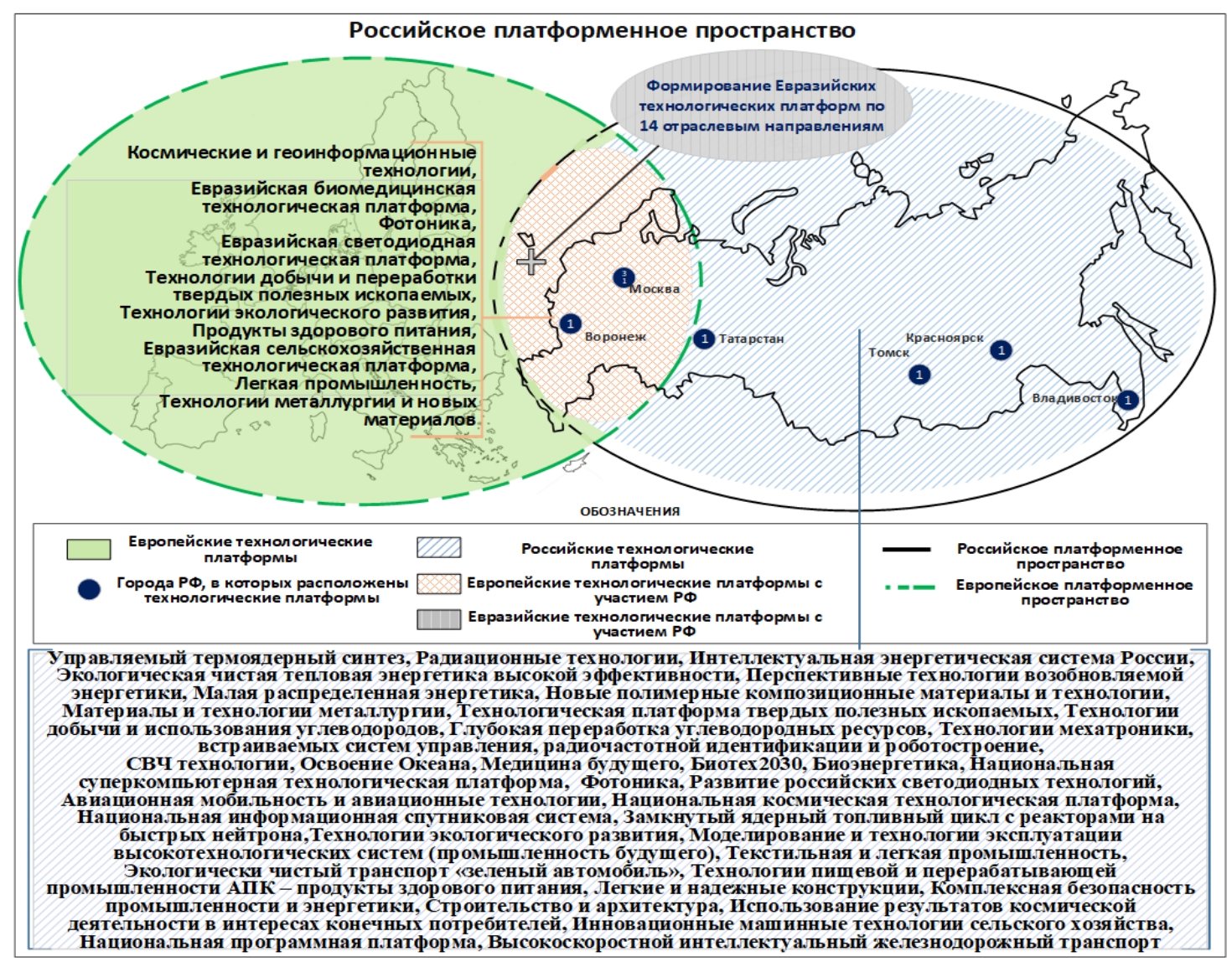

Источник: составлено автором на основании карт источника: www.shutterstok.com и [36; 34]

Рис. 5. Схема российского пространства технологических платформ 


\section{СТРАТЕГИЯ НАУЧНО-ТЕХНОЛОГИЧЕСКОГО РАЗВИТИЯ РОССИИ: ПРОБЛЕМЫ И ПЕРСПЕКТИВЫ РЕАЛИЗАЦИИ}

Российские платформы формируются в 4 этапа (мы также включаем подготовительный). Сначала запускается работа государства по определению направлений развития, затем создается перспективный облик сектора на долгосрочную перспективу и стратегическая программа исследований с планом его внедрения. На рисунке 6 представлен механизм функционирования российских технологических платформ. Важным аспектом в проработке механизма стало включение существующих недочетов функционирования концепции.

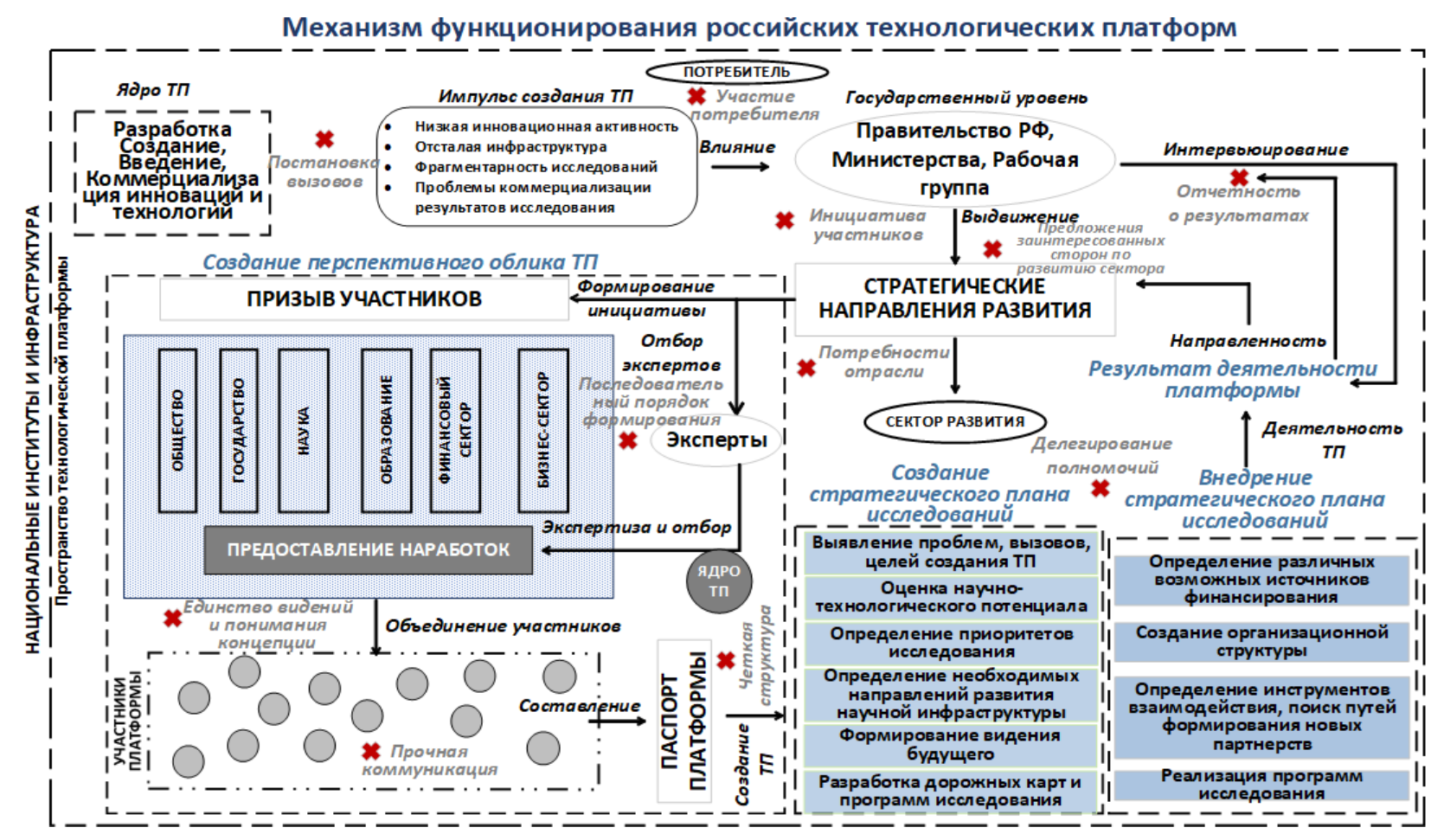

Источник: составлено автором

\section{Рис. 6. Механизм функционирования}

\section{российских технологических платформ}

Инициатива создания ТП в России формировалась с подачи государства. Кроме того, основными импульсами к созданию платформы Правительством РФ стали низкая инновационная активность, слабая коммуникация бизнеса, слабость фундаментальных исследований, а не как в случае европейских 
платформ - прямая потребность общества. Далее формировались приоритетные направления стратегического развития, к которым было необходимо подключаться потенциальным участникам платформы.

Дальнейшим шагом предполагалось создание внешнего вида платформы. Для этого отбирались эксперты, которые проводили оценку проектов, предлагаемых участниками, вследствие чего происходило объединение участников и формирование паспортов ТП. Уже только на следующем шаге платформа формируется и готовится к проработке содержательной структуры инновационного взаимодействия: формулируются конкретные цели, задачи и направления исследования; оценивается научно-технологический потенциал и необходимая инфраструктура; подготавливается видение, дорожная карта и стратегический план. Данный этап можно охарактеризовать как целеполагание и планирование деятельности. В дальнейшем осуществляется продвижение платформ путем реализации проектов и программ НИОКР.

Результат деятельности платформы направлен на достижение целей, поставленных государством по развитию конкретных стратегических направлений. Каждая платформа предоставляет отчет о проделанных этапах исследований и общей деятельности. Однако общей отчетности об эффективности реализации данной концепции государством не проводится, что в целом усложняет представление общей картины состояния платформ. Экспертами рабочей группы проводится выборочное интервьюирование платформ о степени удовлетворенности участников и их уровне подготовки.

Руководство, координация и содействие распространению лучшей практики российских технологических платформы осуществляется Рабочей группой Правительственной комиссии. Финансирование технологических платформ проводится в большей степени государством (71\%). Организационная структура российских технологических платформ представлена инициатором, руководствующим органом, экспертным, наблюдательным и координирующем советом и рабочими группами (рис. 7). 
В процессе адаптации, формирования, запуска и функционировании механизма российских технологических платформ мы выявили ряд деструктивных проблем:

- двоякость концепции, поскольку она не только должна была способствовать модернизации отраслей, но и заполнять пустоты развитости инфраструктуры, спектра исследований и научно-исследовательской кооперации;

- отсутствие инфраструктурной базы, необходимой для раскрытия всего научно-технологического потенциала платформ, из-за чего процесс их развития протекает медленно и затруднительно;

- слабая проработка механизма эффективного функционирования платформ в российских условиях;

- формирование инициативы создания ТП со стороны государства, которое в корне меняет содержательный смысл концепции ТП;

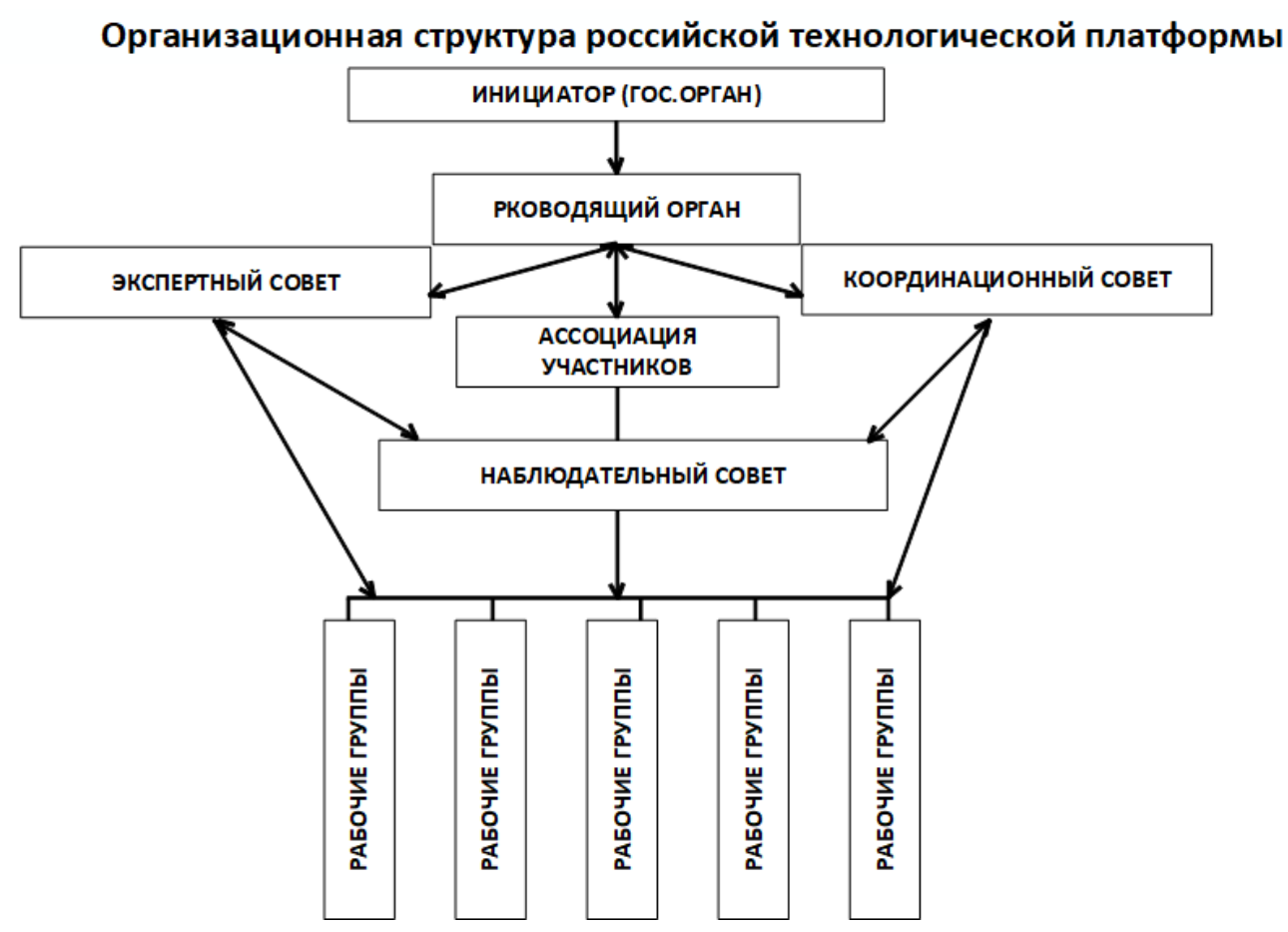

Источник: составлено автором по [17; 34]

\section{Рис. 7. Организационная структура российской технологической платформы}


- нарушение порядка формирования ТП, негативно отразившееся на последовательности выстраивания кооперации. После неудачного первого призыва заявок, в принудительном порядке подключился промышленный и бизнес-сектор. Далее исходя из интересов государства и реальных возможностей секторов и их наработок, формировался макет НИОКР в рамках платформы, и только в дальнейшем, полагаясь на имеющуюся базу, происходило целеполагание и проработка главных стратегических документов платформы. Это послужило переворачиванию исходной концепции о выработке стратегических направлений развития;

- принудительное формирование направлений исследований. Государством были определены критические технологии и отрасли [37], которые необходимо было первостепенно развивать в догоняющем темпе, стратегические идеи и взгляды на решение актуальных социальных проблем остальных секторов участников платформ не учитывались, кроме того, узость представления предполагаемых участников или в целом непонимание механизма привело к тому, что интерес сторон к взаимодействию был низким;

- разобщенность технологических платформ, отсутствие четкого понимания эффектов от сотрудничества и единства взглядов, как и некой привязанности к общему делу;

- неоднозначность структур платформ и отсутствие координации их деятельности. Отсутствие структурированности макета концепции и определенных методологических стандартов, также сложность существующих, вызывает проблемы, связанные с неоднородностью параметров формирования платформ. От создания платформы проходит длительный период времени и результаты сложно оценить. Кооперация мотивируется в большей части государственным финансированием, действия между участниками не координируется и не разделяются. А контроль за текущей деятельность организации протекает вяло и пассивно. Кроме того, ряд экспертов 


\section{СТРАТЕГИЯ НАУЧНО-ТЕХНОЛОГИЧЕСКОГО РАЗВИТИЯ РОССИИ: ПРОБЛЕМЫ И ПЕРСПЕКТИВЫ РЕАЛИЗАЦИИ}

подчеркивают проблемы формального участия стейкхолдеров в платформах и недостатка каналов связи с ними.

Фактически, российские технологические платформы на текущий 2018 год не достигли стадии зрелости и не имеют прорывных результатов. Государственное регулирование за восьмилетний период способствовало запуску механизма, стимулировало к объединению различных групп участников, и направляло платформы на качественную проработку стратегических планов и организационной структуры. Таким образом, результаты данной работы были оформлены в обзоре о Российских технологических платформах, представленным Минэкономразвития РФ в январе 2018 года. Но стоит отметить, что информация о ключевых достигнутых результатах платформ так и не была представлена.

В результате исследования мы пришли к выводу, что реализация концепции осуществляется неэффективно, поскольку концепция не функционирует должным для России образом. Мы видим следующие параметры, которые следует изменить: ослабить государственное воздействие на заинтересованные стороны платформы; переработать концепцию с учетом российских факторов тем, самым убрав двоякость платформ; проработать сопутствующие инструменты инновационного развития, которые будут поддерживать и способствовать развитию технологических платформ; проработать и распространить методологические подходы к формированию, мониторингу и контролю платформ, предусматривающие распределение ролей в перечисленных процессах. Кроме того, мониторинг и контроль должен осуществляться со стороны единства платформенного пространства России; распространить информацию о назначении и выгодах платформ для привлечения большего числа участников, осуществлять продвижение платформ; повысить значимость взглядов всех заинтересованных сторон в принятии стратегических решений. 


\section{СТРАТЕГИЯ НАУЧНО-ТЕХНОЛОГИЧЕСКОГО РАЗВИТИЯ РОССИИ: ПРОБЛЕМЫ И ПЕРСПЕКТИВЫ РЕАЛИЗАЦИИ}

Исследования российских технологических платформ позволило понять процессы их формирования и деятельности в России. А также увидеть ряд концептуальных и функциональных проблем, которые дают представление о том, какие факторы должны быть учтены при выстраивании нашей модели и механизма технологических платформ.

Важно отметить, что технологические платформы достаточно широко распространены в мире. Развитие платформ в странах опирается на эталонный опыт внедрения платформ в Европе и изменяется в соответствии с институциональными условиями страны и научно-технологическими возможностями. Так, допустим, Турция идет по стопам ЕC, не меняя кардинально последовательность действий в формировании и продвижении технологических платформ. В России и Белоруссии механизмы выстроены по схожему алгоритму европейских ТП, но с весомыми содержательными изменениями на первом этапе формирования платформ. Объединяет данный перечень отсутствие четкого оценочного регламента результативности деятельности платформ на национальном уровне, что сужает представление об эффективности механизмов в перечисленных странах.

\section{3 Потенциал России к формированию технологических платформ: оценка ресурсов}

Проведем анализ научно-технологического потенциала и инновационной деятельности РФ. Для того чтобы провести оценку научно-технологического и инновационного потенциала РФ, мы разработали свою последовательность оценки, которая сможет охватить различные блоки эффективности научнотехнологического и инновационного развития страны исходя из методики Всемирного Экономического форума, Комиссии Европейских Сообществ, Всемирного банка, ОЭСР, а также базового доклада к обзору ОЭСР НИС РФ [38]. 


\section{СТРАТЕГИЯ НАУЧНО-ТЕХНОЛОГИЧЕСКОГО РАЗВИТИЯ РОССИИ: ПРОБЛЕМЫ И ПЕРСПЕКТИВЫ РЕАЛИЗАЦИИ}

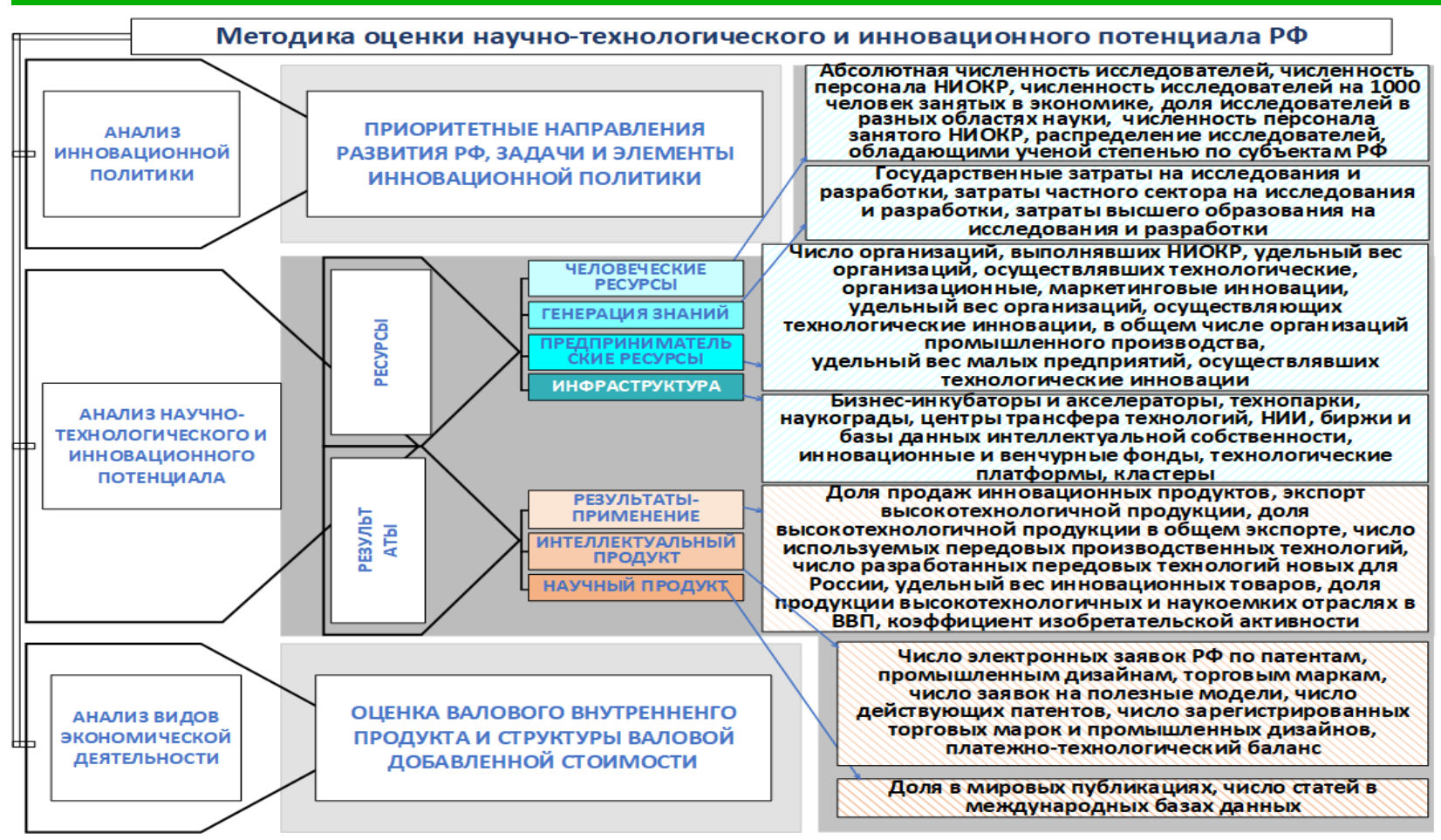

Источник: составлено автором

\section{Рис. 8. Методика оценки научно-технологического}

\section{и инновационного потенциала}

Оценку потенциала мы делим на две части: ресурсы и результаты. В блок ресурсов мы относим комплекс показателей человеческих ресурсов, предпринимательских ресурсов, источников генерации знаний, комплекс показателей, оценивающих развитость инновационной инфраструктуры. К результатам относится три категории показателей: применение результатов, интеллектуальный продукт, научный продукт (рис. 8).

Оценка численности исследователей в сопоставлении со странами: Германия, Великобритания, Франция, Италия, США, Канада, Китай, Южная Корея, Япония представлена на рисунке 9. 


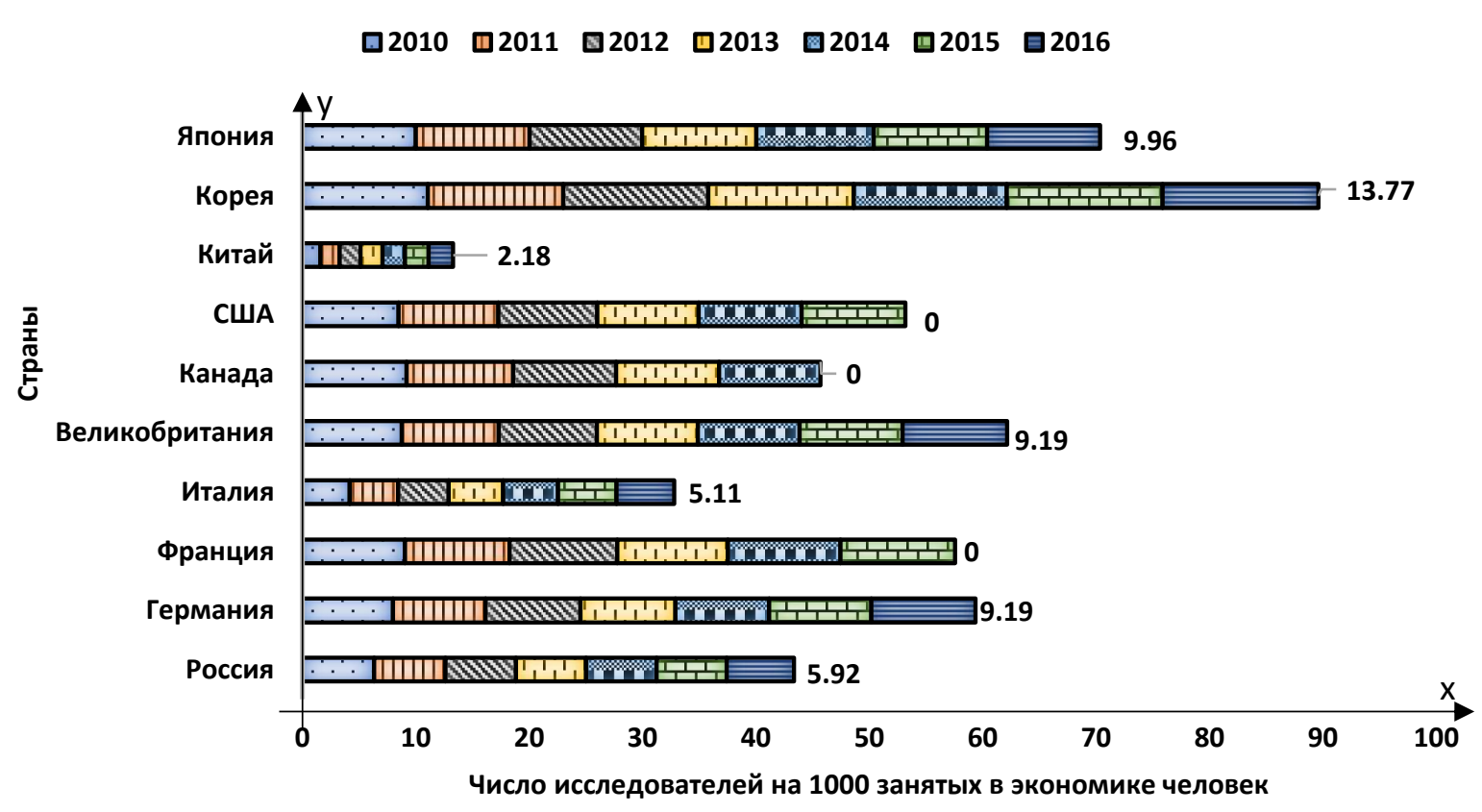

Источник: составлено автором на основе [39]

\section{Рис. 9. Численность исследователей на 1000 человек занятых в экономике с 2010 по 2016 год}

По значению показателя мы можем наблюдать, что высокие позиции занимают такие страны как: Южная Корея, Япония, Франция, Германия, Великобритания, США. Значения показателя в данных странах выше 9 исследователей на 1000 человек. Однако положительная стабильная динамика наблюдается только в Южной Корее, Франции, Германии, США (до 2016 года). Именно всем перечисленным странам уступает Россия в расчете численности исследователей на 1000 человек занятых в экономике. Кроме того, в РФ наблюдается отрицательная динамика с 2014 года, на 2016 год, значение показателя снизилось до 5,92 исследователей на 1000 человек. В целом в отношении России можно сказать, что из числа исследуемых стран она занимает среднее значение по данному показателю. Такие страны как Италия, Китай по значению находятся ниже России. Китай принимает значение показателя в 2,18 исследователей на 1000 человек на 2016 год, Италия $-5,11$ исследователей на 1000 человек. 
Однако мы понимаем, что оценка по данному показателю не совсем точная, поскольку в выбранных странах разный диапазон в доле исследователей. Проранжировав список стран по числу исследователей, в лидеры выбиваются такие страны как: Франция, Китай, США. В этих странах численность исследователей превышает 1,3 млн. чел. В России численность исследователей составила более 370 тыс. чел на 2016 год.

Абсолютная численность исследователей в России была изучена с 2010 по 2017 год (табл.5). Положительная динамика значений показателя отмечена в 2010, 2011, 2014, 2015 годах.

Таблица 5

Абсолютная численность исследователей в России в 2010-2017 гг. (чел.)

\begin{tabular}{|l|c|c|c|c|c|c|c|c|c|}
\hline \multicolumn{1}{|c|}{ Показатель } & 2010 & 2011 & 2012 & 2013 & 2014 & 2015 & 2016 & 2017 & $\begin{array}{c}\text { Темп } \\
\text { роста } \\
2017 \\
\text { к } 2010\end{array}$ \\
\hline $\begin{array}{l}\text { Абсолютная } \\
\text { численность } \\
\text { исследователей, } \\
\text { в т.ч. }\end{array}$ & 368915 & 374746 & 372620 & 369015 & 373905 & 379411 & 370379 & 359793 & $97 \%$ \\
\hline $\begin{array}{l}\text { Абсолютная } \\
\text { численность } \\
\text { докторов наук }\end{array}$ & 26789 & 27675 & 27784 & 27485 & 27969 & 28046 & 27430 & 26076 & $97 \%$ \\
\hline $\begin{array}{l}\text { Абсолютная } \\
\text { численность } \\
\text { кандидатов }\end{array}$ & 78325 & 81818 & 81546 & 80763 & 81629 & 83487 & 80958 & 77251 & $98 \%$ \\
\hline
\end{tabular}

Источник: составлено автором на основе [40]

Темп роста в обозначенный период составил 97 \%. Значительные перепады значений говорят о том, что нет стабильных условий для поддержания текущего уровня числа исследователей, а также внешние меры по стимулированию повышения количества научных кадров неэффективны, что доказывают значения показателя за последние годы. 
Также мы рассмотрели процентное содержание человек с научной степенью в абсолютном значении численности исследователей (рис. 10). На представленной диаграмме можно увидеть, что за весь рассматриваемый период,

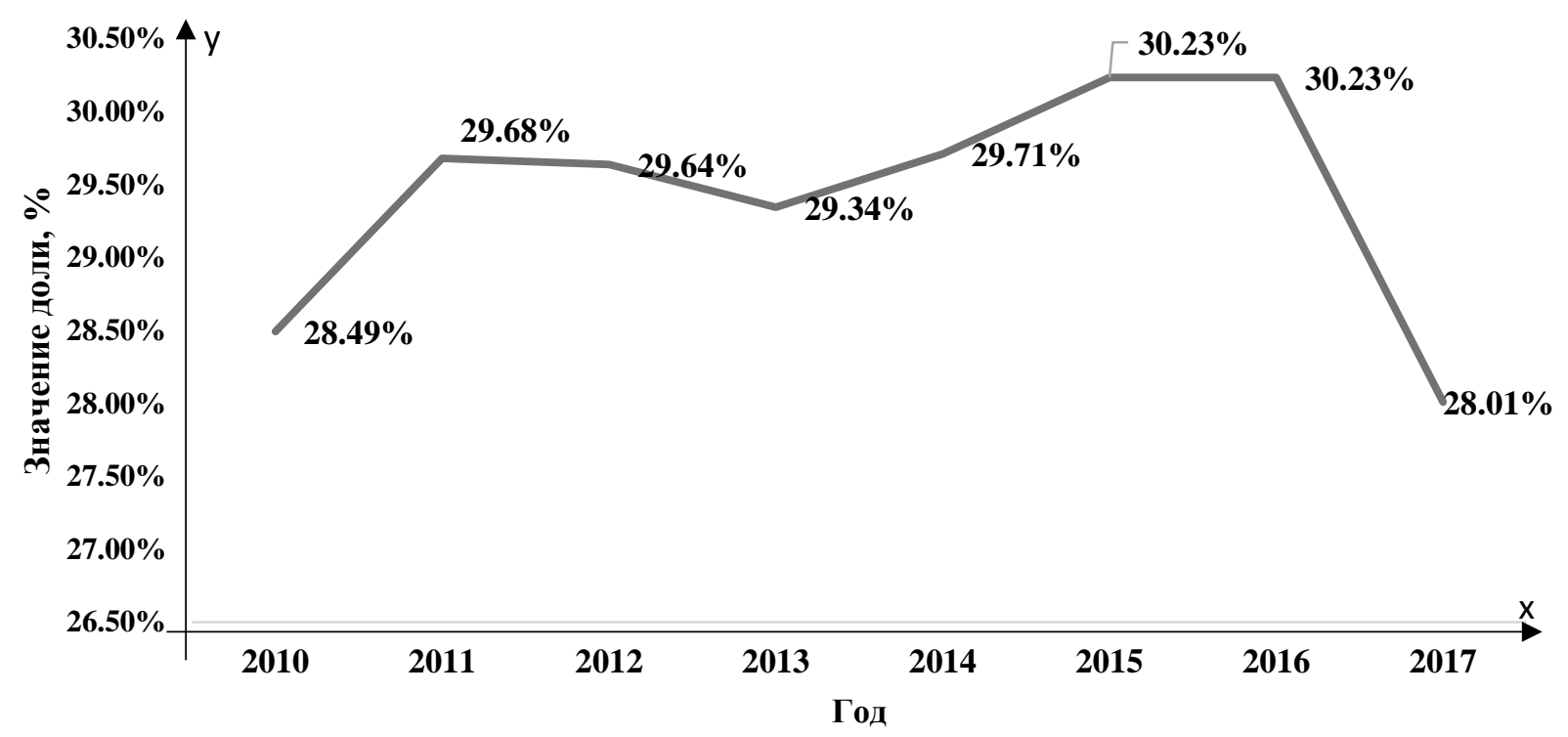

Источник: составлено автором на основе [40]

Рис. 10. Доля исследователей, имеющих научную степень в 2010-2017 гг.

доля не превышала 30,3\%, с 2016 года наблюдается спад числа исследователей до 28,01\%, что ниже показателей 2010 года. Тенденция показателя неоднозначная, поскольку наблюдается сменяющееся снижение и повышение значений. Однако стоит отметить, что ситуация неблагоприятная, в связи с тем, что из более чем 350 тыс. чел., только около 100 тыс. чел. имеют степени кандидатов и докторов наук. На диаграмме (рис. 11) мы видим, что более $60 \%$ исследователей относятся к техническим областям наук. Более $22 \%$ исследователей работают в естественной области науки. Около $5 \%$ отводится на общественные науки. Менее 4\% занимают медицинские, сельскохозяйственные, гуманитарные науки. Значения долей кардинально не менялись в рассматриваемом периоде. 


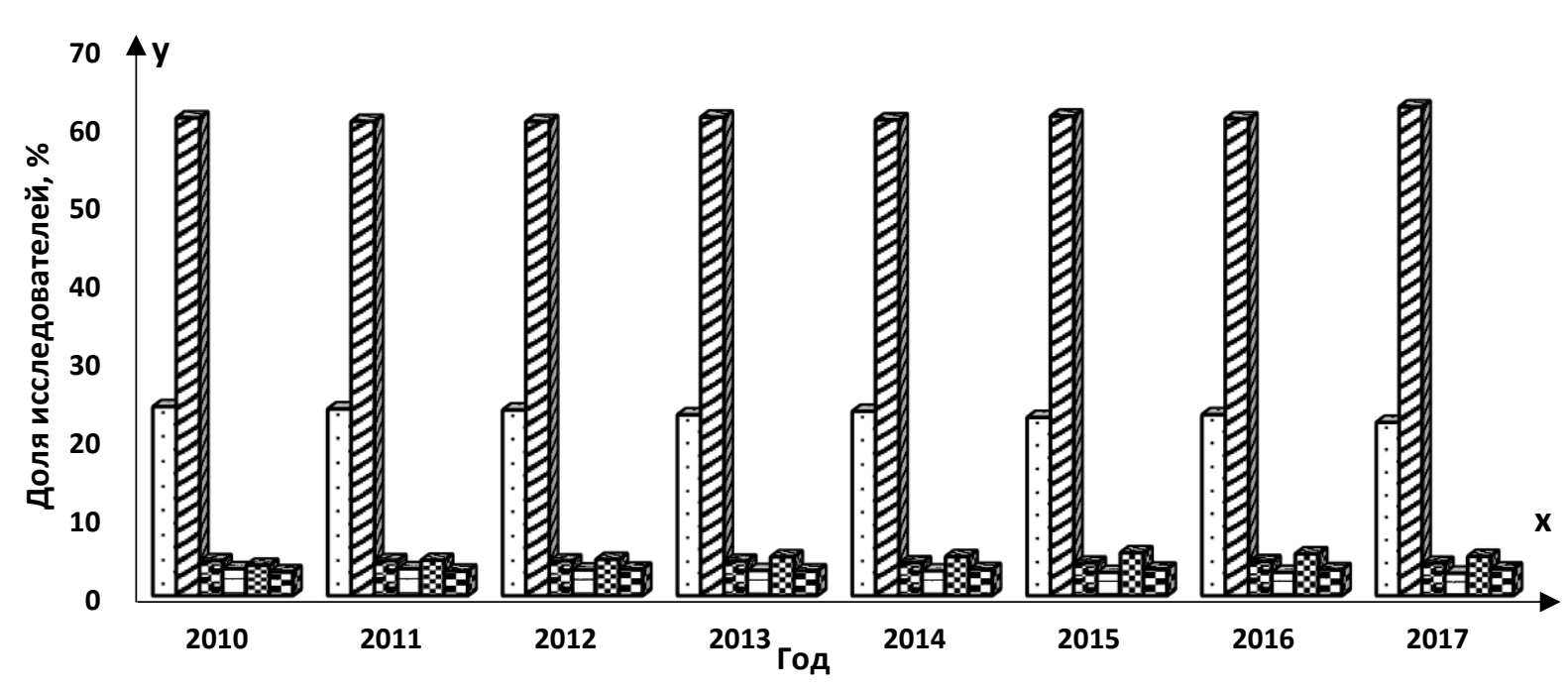

Фестественные Фтехнические

Источник: составлено автором на основе [40]

Рис. 11. Доли исследователей в разных областях науки с 2010 по 2017 год

Рассмотрим также показатель численность персонала, занятого научными исследованиями и разработками (табл.6). Отрицательная динамика показателя наблюдается с 2011 по 2012 год, с 2015 по 2017 год. Темп прироста с 2010 по 2017 год составляет 96\%. Значение показателя на 2017 год снизилось до 707887 чел., что ниже значений базисного года.

Таблица 6

Численность персонала занятого научными исследованиями и разработками в 2007-2017 гг. (в человек)

\begin{tabular}{|l|c|c|c|c|c|c|c|c|c|}
\hline $\begin{array}{l}\text { Численность } \\
\text { персонала }\end{array}$ & 2010 & 2011 & 2012 & 2013 & 2014 & 2015 & 2016 & 2017 & $\begin{array}{c}\text { Темп } \\
\text { прироста } \\
2017 \text { к 2010 }\end{array}$ \\
\hline $\begin{array}{l}\text { всего, } \\
\text { в т.ч.: }\end{array}$ & 736540 & 735273 & 726318 & 727029 & 732274 & 738857 & 722291 & 707887 & $96 \%$ \\
\hline исследователи & 368915 & 374746 & 372620 & 369015 & 373905 & 379411 & 370379 & 359793 & $98 \%$ \\
\hline техники & 59276 & 61562 & 58905 & 61401 & 63168 & 62805 & 60441 & 59690 & $100 \%$ \\
\hline $\begin{array}{l}\text { вспомогатель- } \\
\text { ный персонал }\end{array}$ & 183713 & 178494 & 175790 & 175365 & 173554 & 174056 & 171915 & 170347 & $92 \%$ \\
\hline $\begin{array}{l}\text { прочий } \\
\text { персонал }\end{array}$ & 124636 & 120471 & 119003 & 121248 & 121647 & 122585 & 119556 & 118057 & $94 \%$ \\
\hline
\end{tabular}

Источник: составлено автором на основе [40] 
Если рассматривать персонал занятого научными исследованиями и разработками в долевом соотношении, то видно, что более $50 \%$ от общего числа составляют исследователи, в среднем $24,08 \%$ занимает вспомогательный персонал, прочий персонал составляет долю в 16,6\%, а категория техники в среднем занимают $8,36 \%$.

Рассмотрим, как распределяются исследователи, обладающие учеными степенями по субъектам РФ (рис.12). Более 52\% исследователей приходится на Центральный федеральный округ (ФО). Далее следует Северо-Западный ФО и Сибирский, где доля исследователей составляет в среднем около 12,5\% и $10,7 \%$ соответственно.

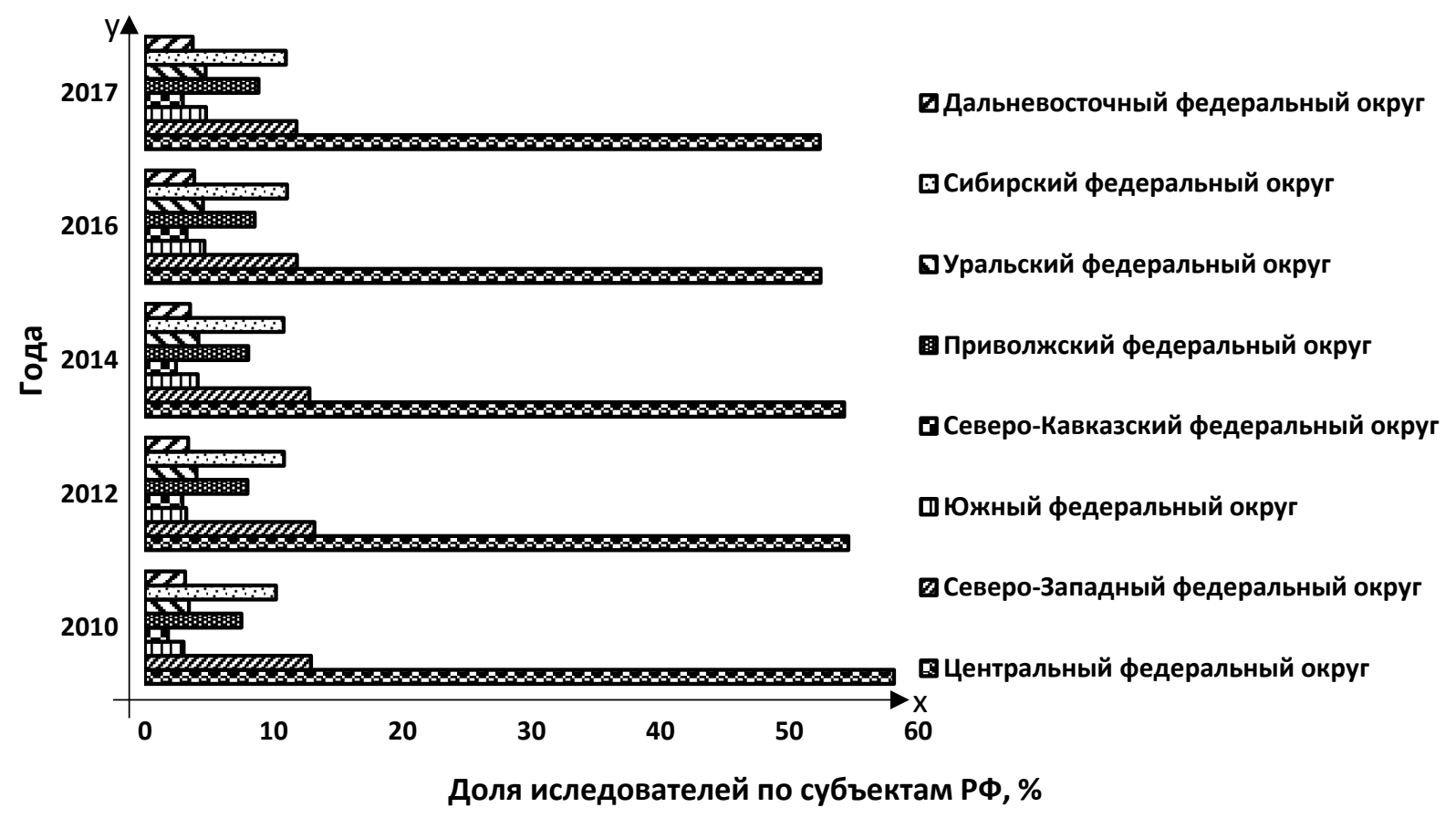

Источник: составлено автором на основе [40]

Рис. 12. Распределение исследователей, обладающими ученой степенью, по субъектам РФ с 2010 по 2017 год

Таким образом, уровень на котором находится исследовательский запас РФ - средний уровень, среди экономически развитых стран. В отношении 
абсолютного числа исследователей значение невысокое, по сравнению с другими странами, кроме того, наблюдается отрицательная динамика с 2016 года, что просматривается и по показателю численность персонала, занятого научными исследованиями и разработками. Доля исследователей, обладающих ученой степенью, составляет менее 30\%. Их основное распределение приходится на Центральный, Северо-Западный ФО. Данный факт дает основание полагать, что другие регионы менее привлекательны к исследовательской деятельности, или не могут в полной мере реализовать свой потенциал.

На рисунке 13 продемонстрировано изменение внутренних затрат на исследования и разработки стран с 2010 по 2016 год.

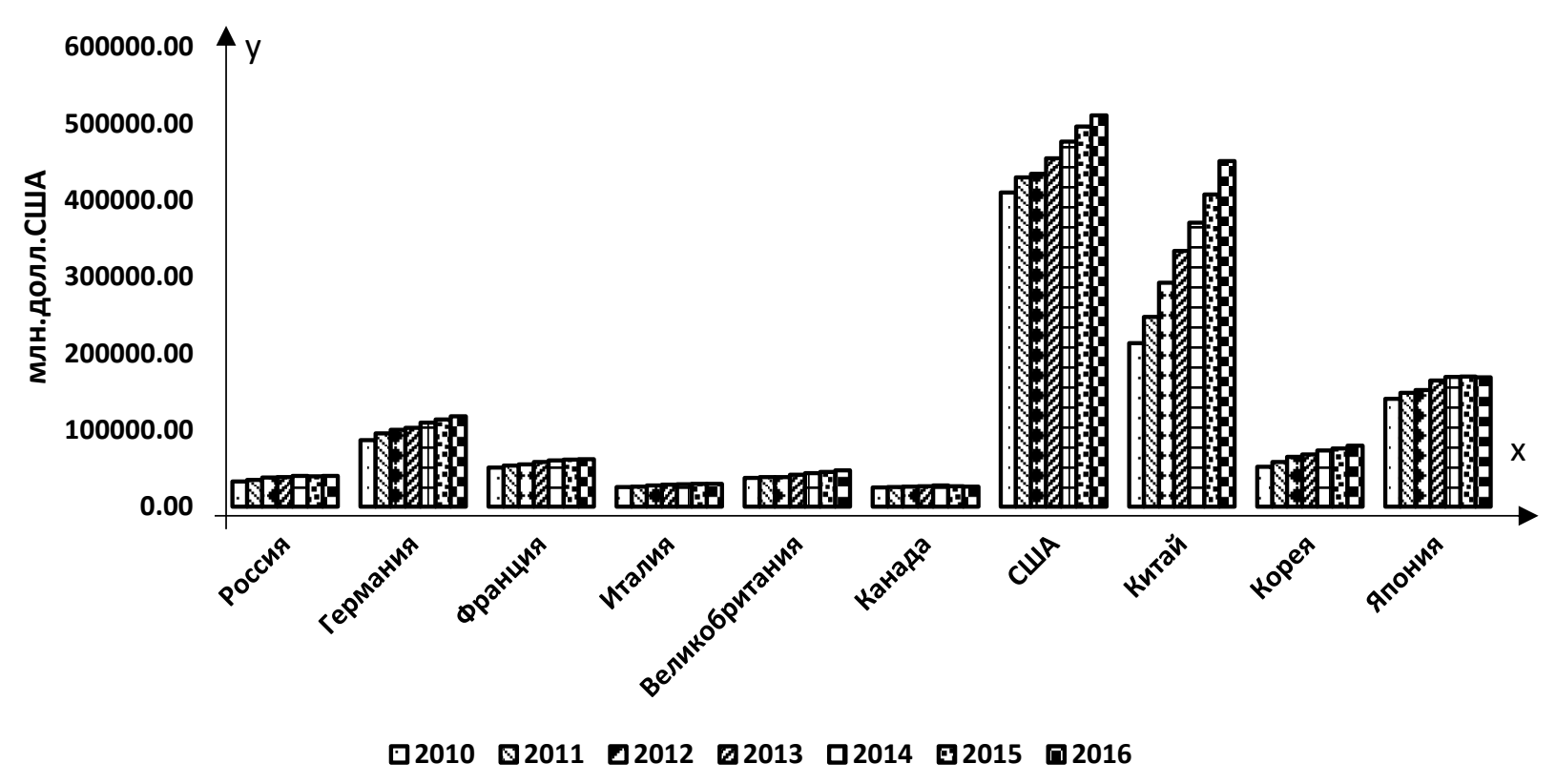

Источник: составлено автором на основе [41]

\section{Рис. 13. Изменение внутренних затрат на исследования и разработки} по ППС с 2010 по 2016 год

Самые высокие значения среди представленных стран занимает США и Китай. По ППС с 2010 по 2016 год в стране отмечена положительная динамика, 
а по темпам среднегодового прироста наблюдается нестабильная тенденция (рис. 14). Китай демонстрирует высокие темпы прироста - нижнее значение прироста составляет 8,77, верхнее 15,78 за рассматриваемый период (рис. 16). Мы видим, что стабильные темпы роста демонстрируют только США и Германия. Остальные страны показывают неспособность удерживать стабильные темпы прироста затрат на создания исследований и разработок в рассматриваемый период.

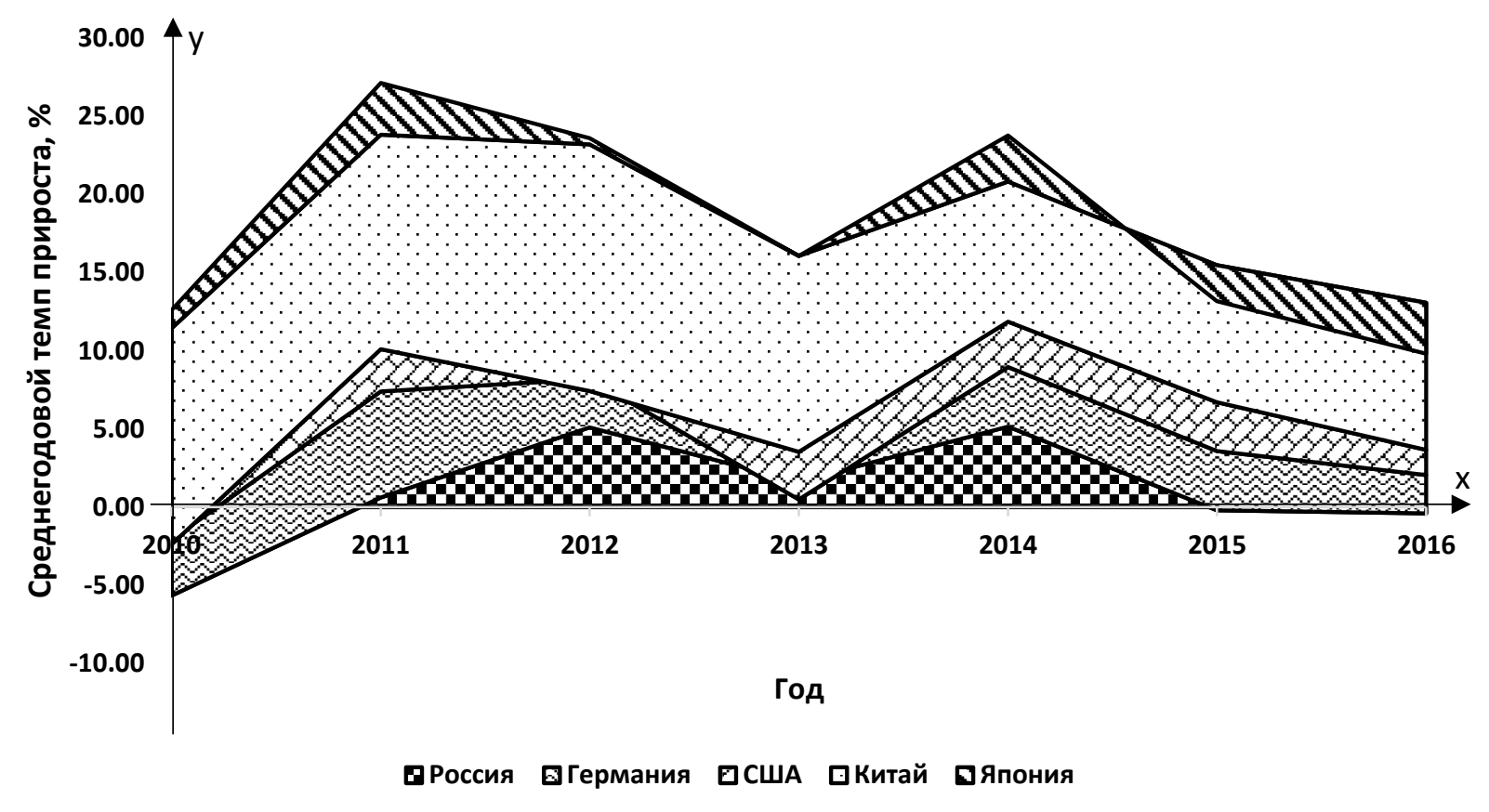

Источник: составлено автором на основе [41]

\section{Рис. 14. Изменение внутренних затрат на исследования и разработки по среднегодовому темпу прироста с 2010 по 2016 год}

По ППС затраты на исследования и разработки в Китае выросли в 2,11 раз. Так на 2010 год затраты составляли 213485,66 млн. долл., а уже в 2016 - 451201,45 млн. долл. Далее по объему следует Япония и Германия, но уже с более низкими показателями по отношению к этим двумя странам. Россия уступает по объемам затрат, среднее значение по ППС в России 
составляет 37820,42 млн. долл. Процент затрат от ВВП за рассматриваемый период не превышал 1,1\% (рис. 15). Что представляет собой самое меньшее значение в рассматриваемых странах. Отрицательная динамика отмечена с 2015 года, где снизился уровень затрат по ППС (рис. 14) и значительно сократились темпы среднегодового прироста.

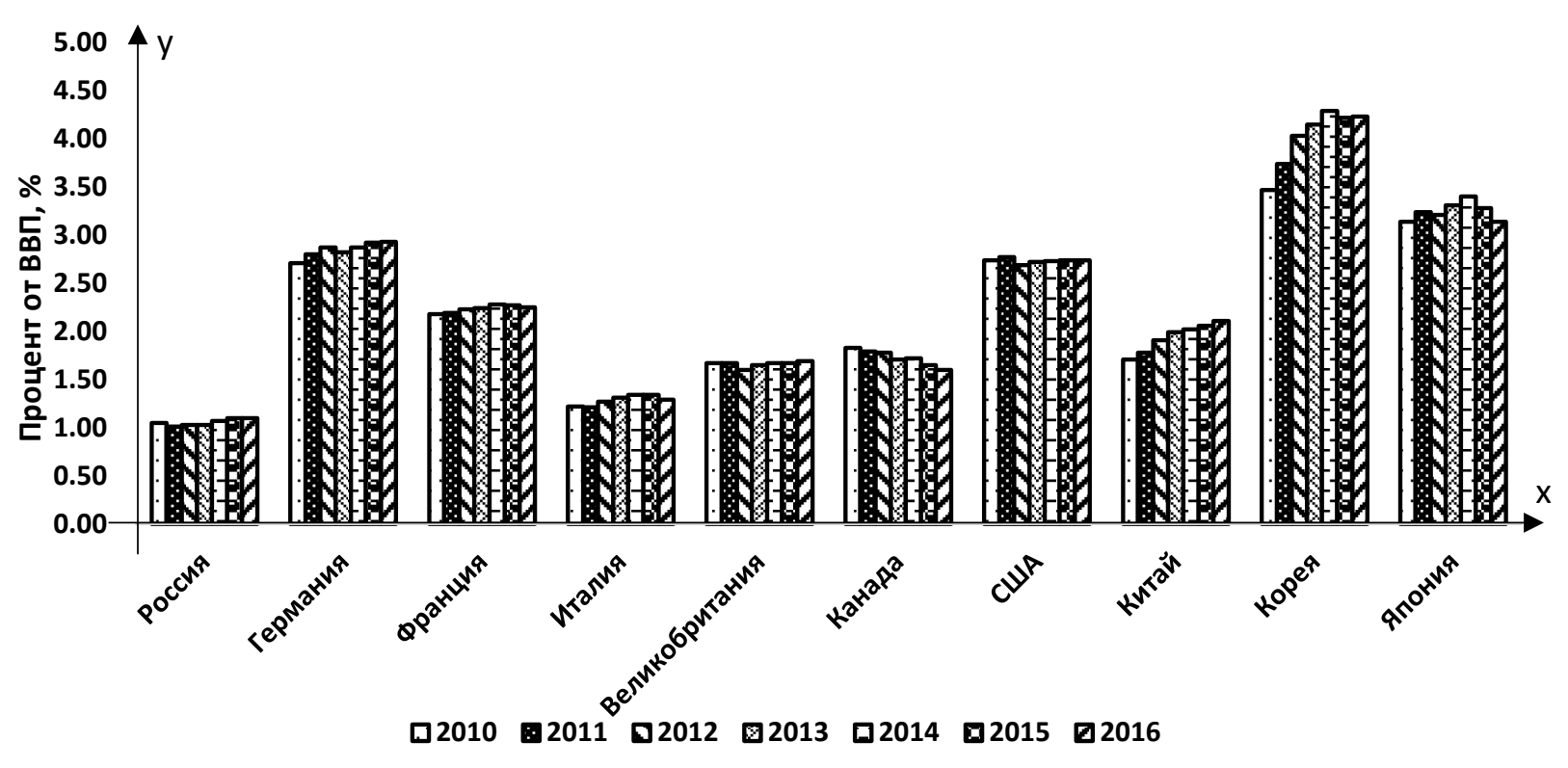

Источник: составлено автором на основе [41]

Рис. 15. Изменение внутренних затрат на исследования и разработки с 2010 по 2016 год, \% от ВВП

По доле затрат от ВВП лидируют такие страны как Южная Корея на 2016 год значение достигло 4,23\% от ВВП, Япония со значением 3,14 и Германия со значением 2,93\% от ВВП. Диапазон российских значений в доли затрат на исследования и разработки колебался от 1,01 до $1,1 \%$, что также показывает низкие темпы прироста.

На рисунке 16 представлены доли затрат на исследования и разработки по странам в государственном секторе, бизнес секторе и в секторе высшего образования. Здесь наглядно видно, что доля затрат сектора высшего 
образования наименьшая по всем странам. Китай и США уделяют значительное количество средств на исследования и разработки в бизнес секторе, отсюда видно, что основная доля затрат на исследования и разработки обеспечивается за счет предпринимательского капитала.

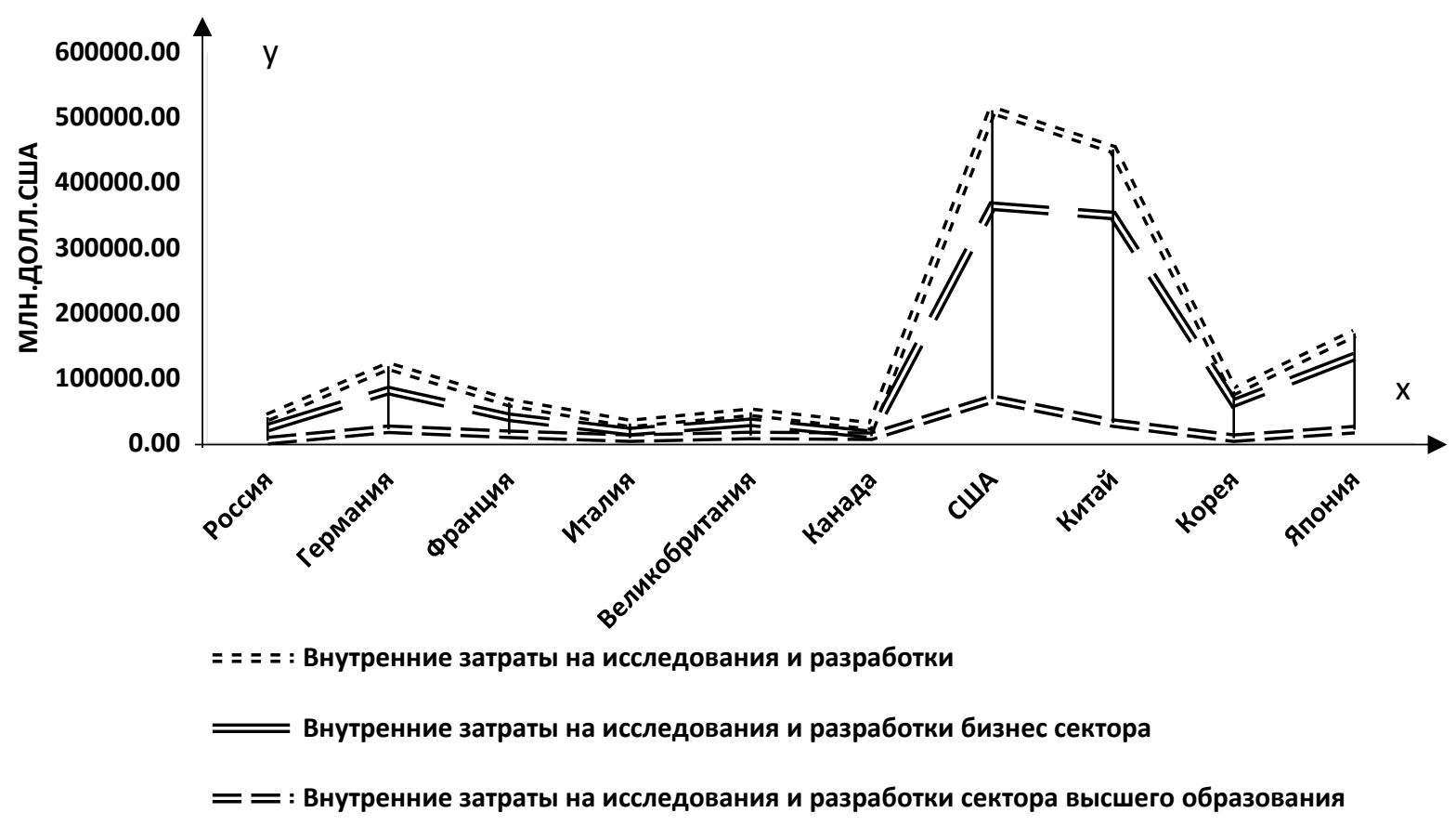

Источник: составлено автором на основе [41]

\section{Рис. 16. Изменение затрат на исследования и разработки по ППС в различных секторах}

В России на 2016 год затраты предпринимательского сектора составили 0,64\% от ВВП, высшего образования - 0,1\% (рис. 17). Данные значения бизнеса и высшего образования в процентах от ВВП с 2010 по 2016 год значительно ниже среди исследуемых стран. В России сектор высшего образования в меньшей степени затрачивает собственные средства на создание исследований и разработок. 

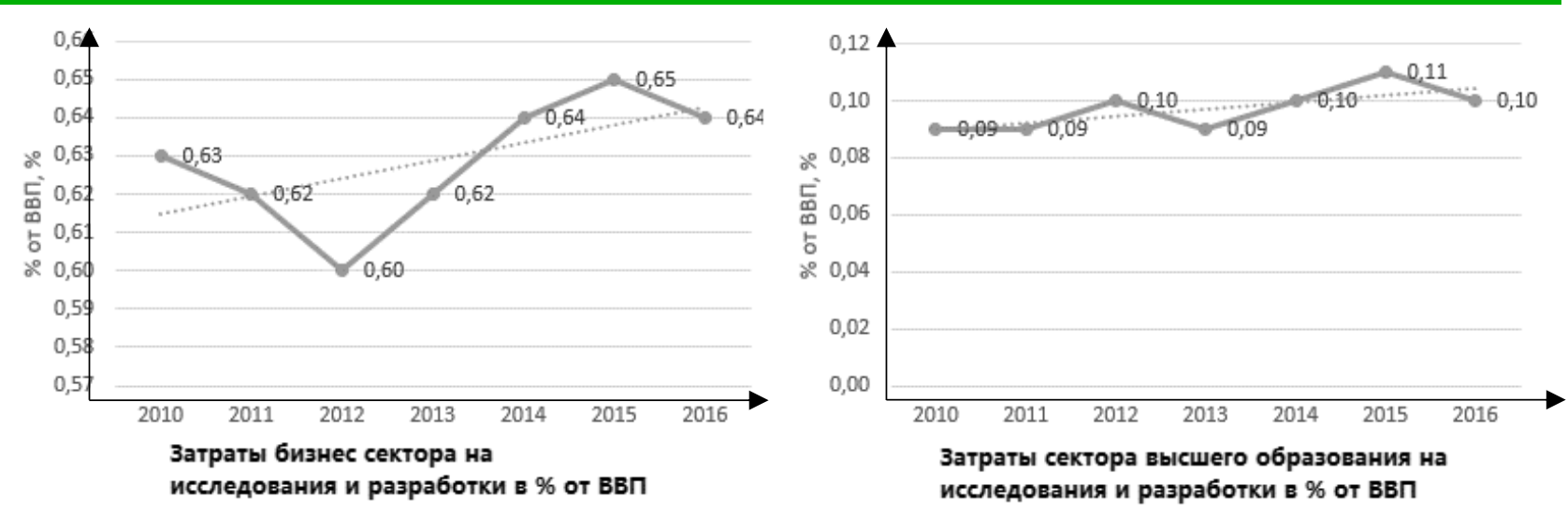

Источник: составлено автором на основе [40]

\section{Рис. 17. Затраты России на исследования и разработки}

Далее используя статистическую базу Росстата, мы посмотрели на какие цели главным образом идут затраты на исследования и разработки в РФ (рис. 18). Таким образом, мы получили, что большая часть затрат идет на развитие экономики, другие цели и общее развитие науки.

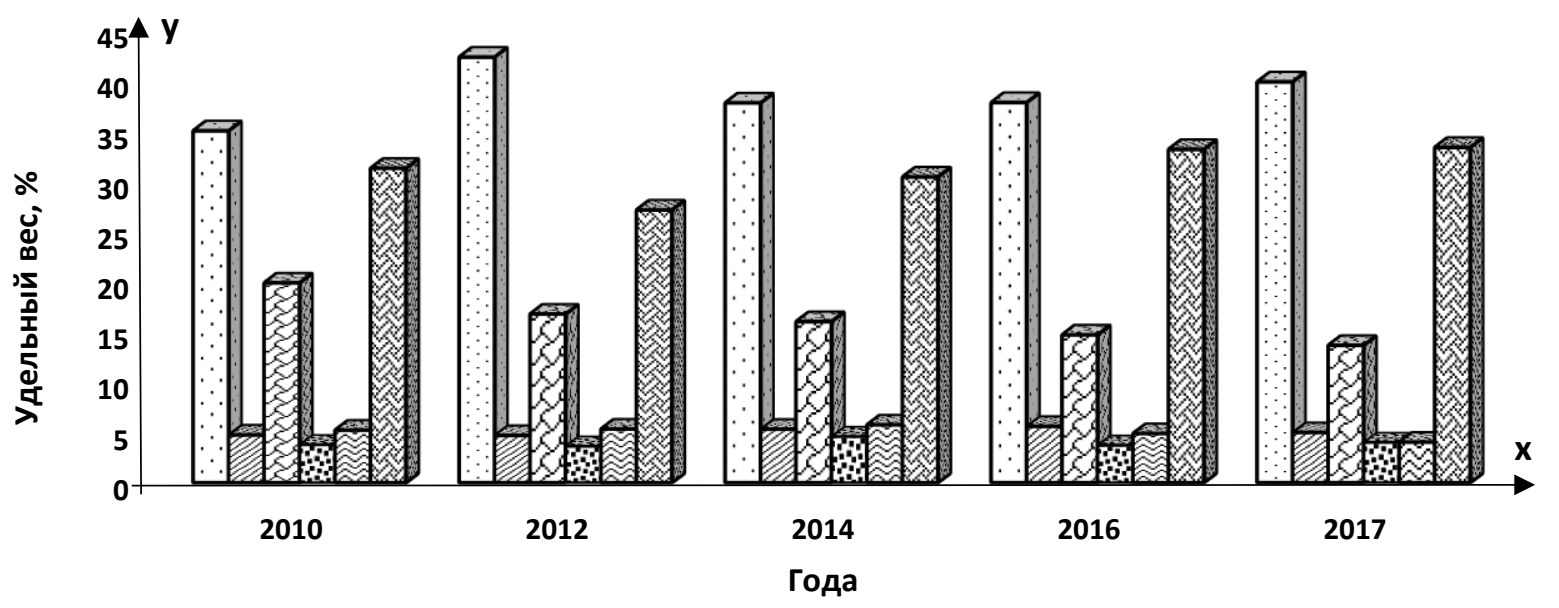

\footnotetext{
口Развитие экономики

هСциальные цели

ФОбщее развитие науки

요 Исследование и использование Земли и атмосферы

ФИспользование космоса в мирных целях
}

Источник: составлено автором на основе [40]

Рис. 18. Внутренние затраты России на исследования и разработки по социально-экономическим целям с 2010 по 2017 год в долях 
Кроме того, мы изучили направления распределения затрат РФ на исследования и разработки по федеральным округам (рис. 19). В основном затраты приходятся на Центральный ФО, Приволжский и Северо-Западный ФО. По полученным данным, мы можем сделать вывод о том, что концентрация затрат в большей степени приходится только на три округа.

Таким образом, мы вынуждены констатировать достаточно низкие значения России в сравнении с другими странами в части финансового обеспечения исследований и разработок. Кроме того, по изученным показателям с 2015 года также наблюдается отрицательная тенденция и в части изучения исследовательского ресурса. На наш взгляд, финансирование научного сектора необходимо повысить, так как с текущей отрицательной динамикой высок риск значительного сокращения научно-исследовательского потенциала страны.

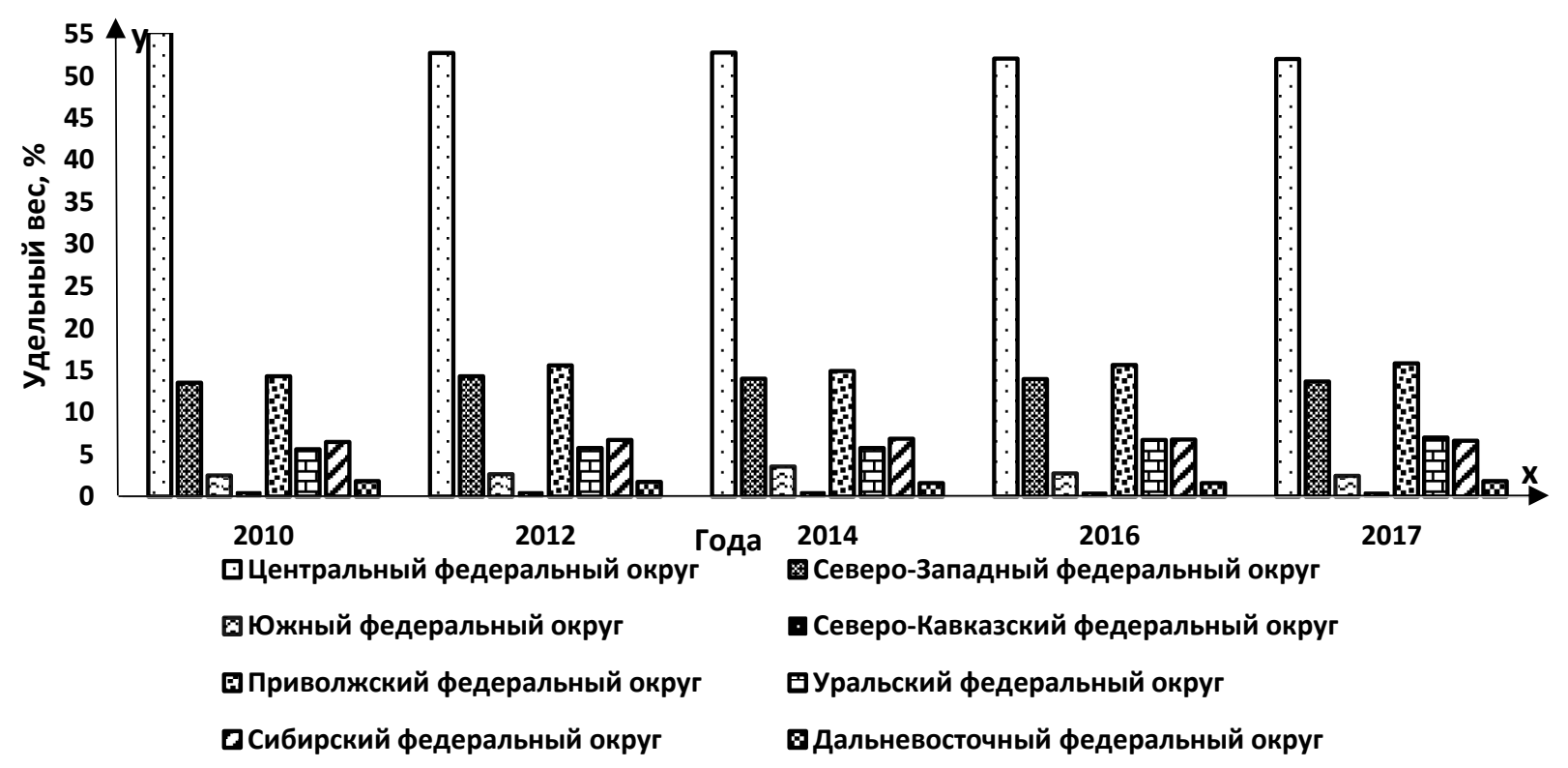

Источник: составлено автором на основе [40]

\section{Рис. 19. Внутренние затраты России по федеральным округам с 2010 по 2017 год в долях}


Число организаций, выполнявших научные исследования и разработки в период с 2010 года по 2017 год (рис. 20), значительно увеличилось в 2011 году и в 2015 году, в остальное время наблюдается спады этого показателя. Резкое изменение количества на временном промежутке с 2014 по 2017 год, говорит о том, что компании неустойчивы в данной сфере деятельности.

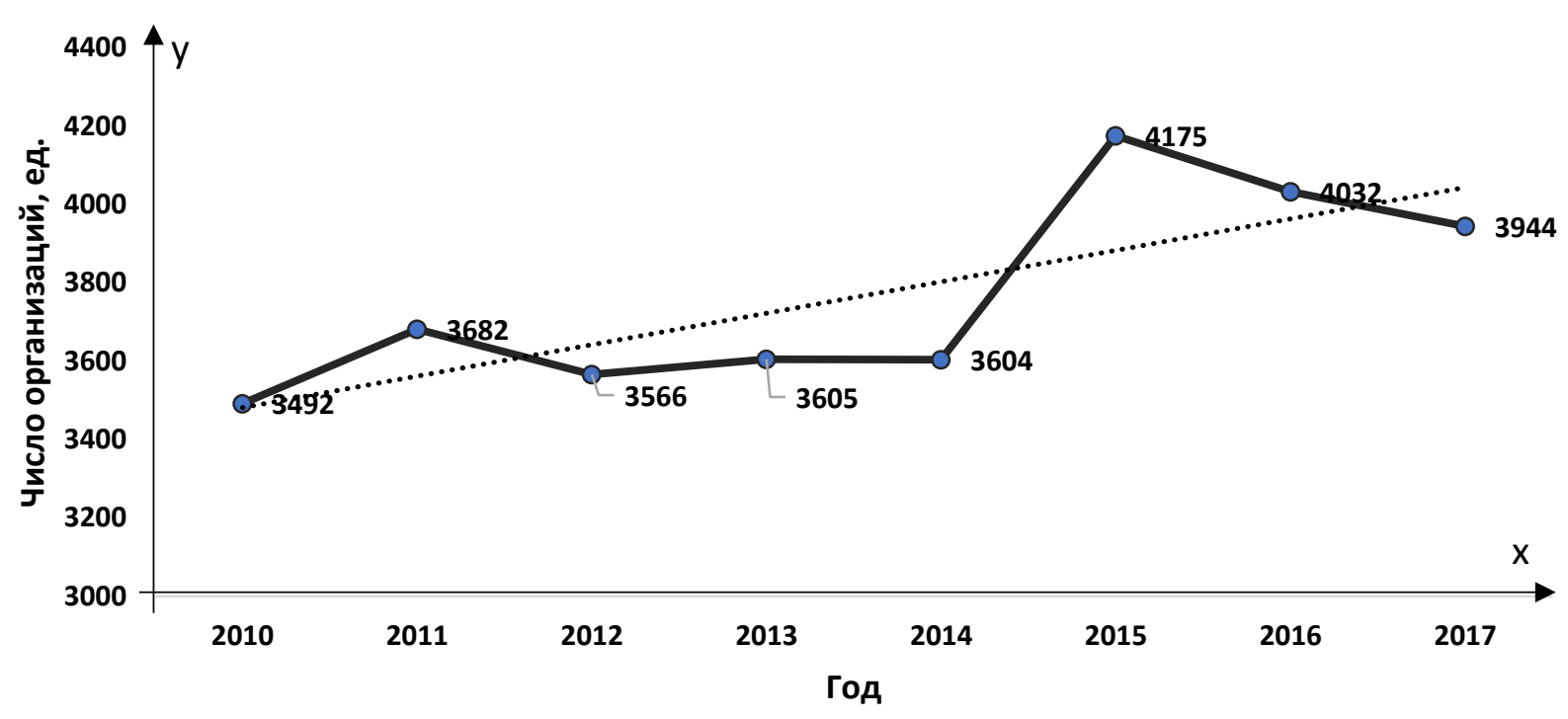

Источник: составлено автором на основе [42]

\section{Рис. 20. Изменение числа организаций, выполнявших научные исследования и разработки с 2010 по 2017 год}

Так, например, повышение на более чем 500 организаций в 2015 году составило 4175 организаций, однако в 2017 году, практически на половину от повышения в 2015 году, снизилось число организаций в сфере НИОКР и составило 3944 единицы. Далее мы обратили внимание на инновационную активность компаний, осуществлявших технологические, организационные, маркетинговые инновации (рис. 21). 


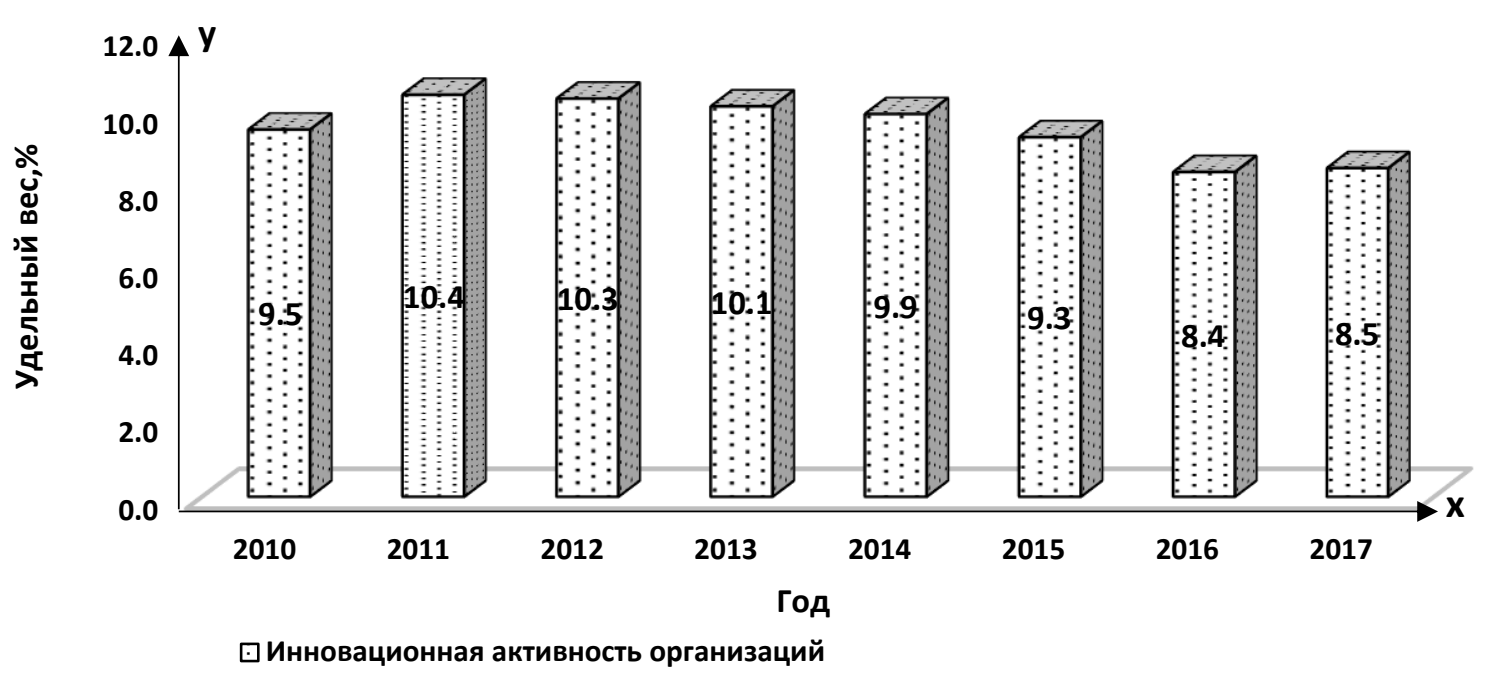

Источник: составлено автором на основе [40]

\section{Рис. 21. Изменение удельного веса организаций, осуществлявших технологические, организационные, маркетинговые инновации В 2010-2017 гг.}

На рисунке 21 видно, что процент инновационных компаний не превышал за все время 10,4\%, и то, данное значение наблюдалось только в 2011 году, после чего наблюдается тенденция к снижению. Так, на 2017 год, удельный вес компаний достиг 8,5\%, что ниже базового значения 2010 года.

Для того чтобы более точно сказать, насколько выражено отставание России на фоне других стран, мы провели выборочный анализ, по показателю удельный вес организаций, осуществляющих технологические инновации, в общем числе организаций промышленного производства по странам за 2016 год (рис. 22). 


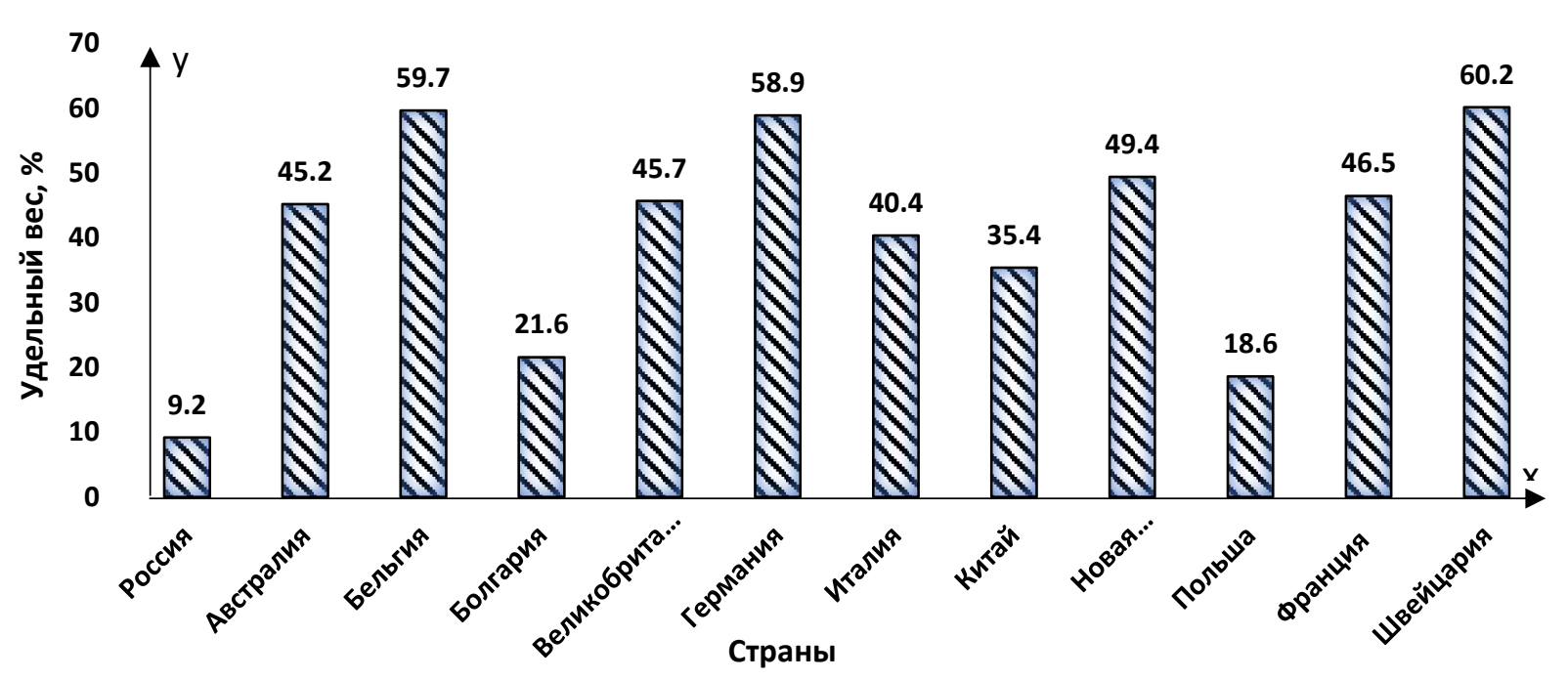

Источник: составлено автором на основе [43]

\section{Рис. 22. Изменение удельного веса организаций, осуществляющих технологические инновации за 2016 год}

На рис. 22 видно, что из представленных стран Россия занимает самые низкие позиции, с удельным весом компаний в 9,2\%. В таких странах как Швейцария, Бельгия и Германия значения достигают $60 \%$ или значения близкие к этому, что практически в 6 раз больше, чем в России. Данный факт дает основания полагать, что в России наблюдается низкая инновационная активность компаний, как среди всех осуществлявших технологические, организационные, маркетинговые инновации, так и осуществляющих технологические инновации, в общем числе организаций промышленного производства.

На рисунке 23 представлены организации, выполнявших научные исследования и разработки, по типам организаций и секторам деятельности с 2010 по 2017 гг. по РФ. Так, большую долю занимают научноисследовательские организации с долей 39,98\% на 2017 год, причем с 2010 года 
данное значение уменьшилось на 12,7\%. Зато доля второй категории по типам организаций - образовательные организации высшего образования, увеличилась на 9,78\% с 2010 года, составив в 2017 году 24,59\%. Также на протяжении всего периода увеличивалась и доля организаций промышленности, имевшие научно-исследовательские, проектноконструкторские подразделения на 2,8\% с 2010 года.

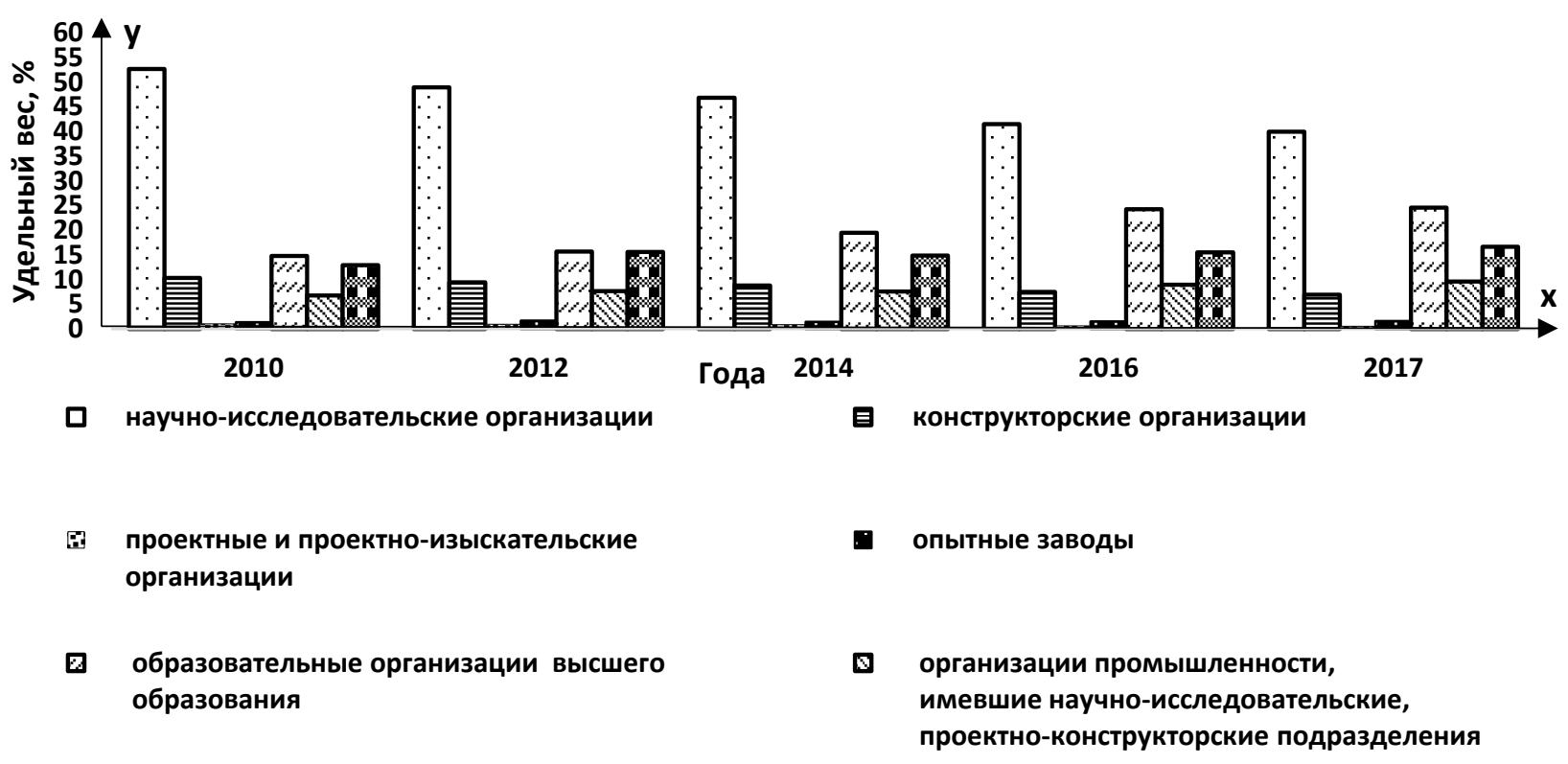

Источник: составлено автором на основе [43]

\section{Рис. 23. Изменение структуры организаций, выполнявших научные исследования и разработки с 2010 по 2017 год}

В абсолютном выражении на 2017 год число организаций представлено на рис. 24. 


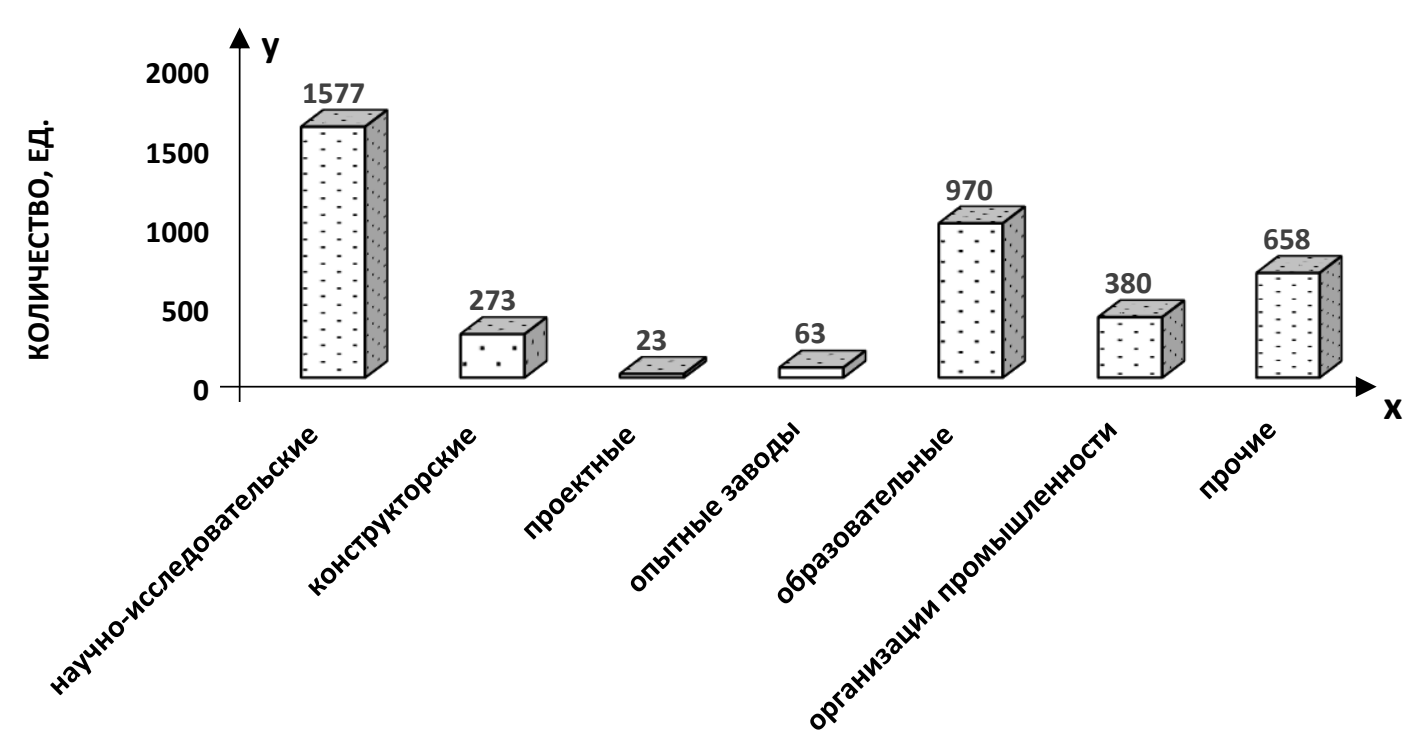

ТИПЫ ОРГАНИЗАЦИЙ

Источник: составлено автором на основе [43]

\section{Рис. 24. Абсолютное число организаций, выполнявших научные исследования и разработки по типам организаций на 2017 год}

В отношении деятельности организаций НИОКР по секторам (рис. 25) видно, что предпринимательский и государственный сектор занимают практически равную долю в общем весе организаций, занимающихся НИОКР. Так, с 2010 по 2011 год два данных сектора занимали практически одинаковое значение по числу организаций, далее наблюдается сокращение доли предпринимательского сектора по 2014 год. В 2015 году отражается повышение в каждых секторах, затем снижение на 2017 год. Так, на 2017 год число организаций предпринимательского сектора сократился на 113 организаций по сравнению с 2010 годом. 


\section{СТРАТЕГИЯ НАУЧНО-ТЕХНОЛОГИЧЕСКОГО РАЗВИТИЯ РОССИИ: ПРОБЛЕМЫ И ПЕРСПЕКТИВЫ РЕАЛИЗАЦИИ}

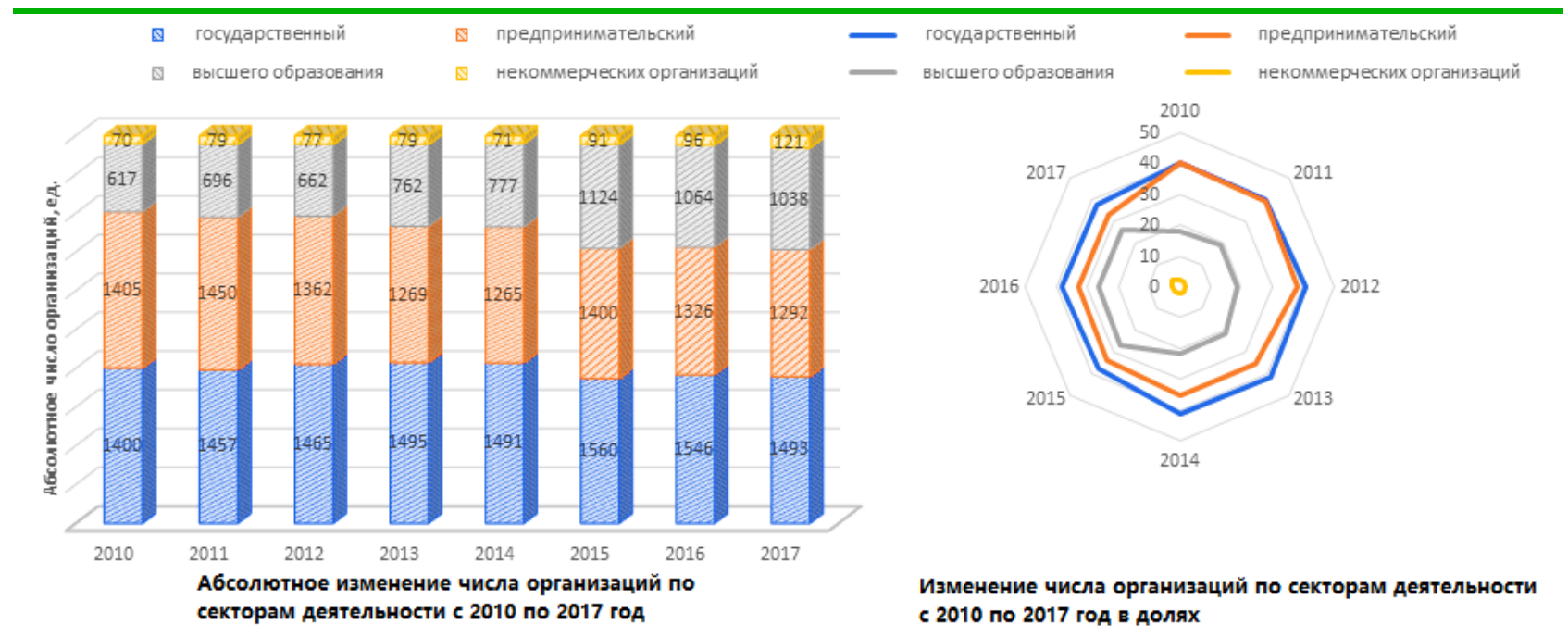

Рис. 25. Соотношение организаций, выполнявших научные исследования и разработки по секторам деятельности с 2010 по 2017 год

Снижение удельного веса организаций предпринимательского сектора и в целом его практически равное значение с государственным, говорит о том, что данная сфера до сих пор находится в государственном секторе, ограничивая предпринимательский потенциал. Это дает понять, что переход к инновационной модели роста находится в замедленной стадии. Что касается малого предпринимательства, то на рис. 27 видна его немногочисленность, на 2011 год существовало всего 1276 компаний, осуществляющих технологические инновации, что в удельном весе оставило всего 5,1\%. Однако в последующие годы наблюдается тенденция к снижению, значение числа организаций снизилось до 1189 компаний в абсолютном выражении, что составило 4,5\% в удельном весе.

Следовательно, инновационная активность малого предпринимательства крайне низкая. В связи с этим, можно сделать вывод, что малому предпринимательству не хватает условий для конкурентоспособного функционирования, что в конечном итоге заставляет их ликвидировать свою деятельность. 


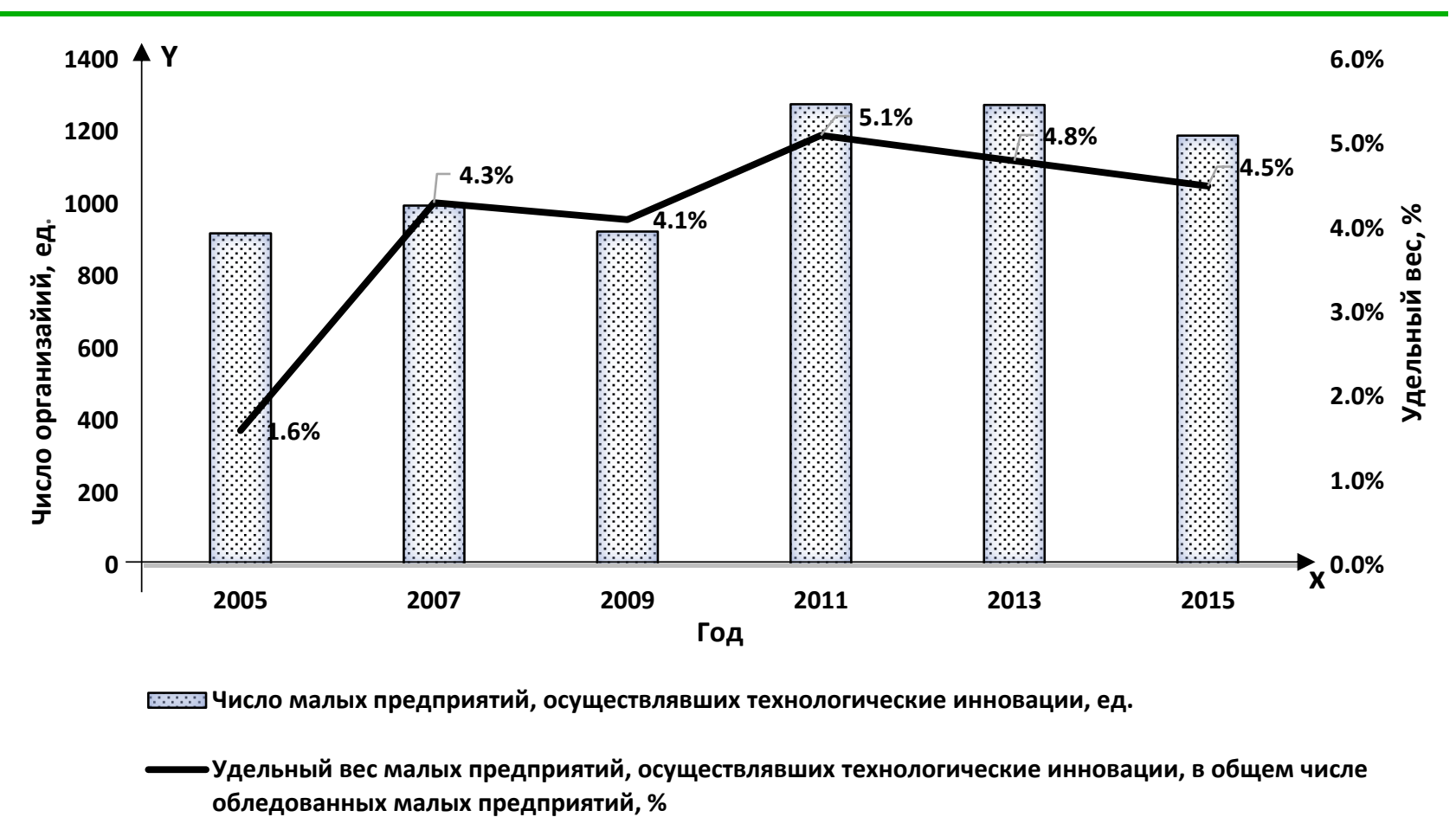

Источник: составлено автором на основе [40]

\section{Рис. 26. Абсолютное число и удельный вес малых предприятий, осуществлявших технологические инновации с 2005 по 2015 год}

Инновационная инфраструктура России имеет расширенную сеть учреждений различного уровня и направленности. Начиная от представителей сектора управления и заканчивая единицами, которые осуществляют научноисследовательскую и инновационную деятельность. В число подобных единиц входят: бизнес-инкубаторы и акселераторы, технопарки, наукограды, центры трансфера технологий, НИИ, биржи интеллектуальной собственности, базы данных интеллектуальной собственности, инновационные и венчурные фонды, технологические платформы, кластеры.

Статистическое наблюдение за бизнес-инкубаторами и акселераторами России осуществляется Ассоциацией акселераторов и бизнес-инкубаторов России. Представленная ассоциацией интерактивная карта инновационной экосистемы России позволяет наглядно оценить концентрацию не только акселераторов и бизнес-инкубаторов, но и кластеров, технопарков, 
региональных центров инжиниринга. Так, в целом, можно учесть большую часть инновационной инфраструктуры, поддерживающей предпринимательство и вовлекающей в инновационную деятельность промышленность.

В отношении бизнес-инкубаторов мы выявили, что насчитывается 260 бизнес-инкубаторов, включающих в себя частный, университетский, инфраструктурный и региональный уровень. Большее сосредоточение бизнесинкубаторов приходится на Республику Саха, Пензенскую область, Московскую область и Москву, а также на Нижегородскую область. Акселераторов насчитывается 87, которые в большей степени сконцентрированы в Москве и Татарстане. Региональные инжиниринговые центры особенно сконцентрированы в Татарстане и Москве. Стоит отметить, что правительство РФ активно поддерживает открытие бизнес-инкубаторов и акселераторов, что доказывает увеличение приема заявок на 2017 год (по данным ассоциации) и специальные программы, поддерживающие развитие и запуск малого предпринимательства.

На субъекты Дальнего Востока приходится 43 элемента инновационной инфраструктуры. В число неактивных субъектов входят Чукотский автономный округ и Камчатский край. Большее число инфраструктурных объектов идет на Республику Саха и Хабаровский край. Также стоит отметить, что в данном регионе присутствуют кластеры: Инновационный территориальный кластер авиастроения и судостроения Хабаровского края, кластер производителей мебели, деревообработки и смежных отраслей и туристско-рекреационный кластер «Северная мозаика» Республики Саха [44].

Аналитические и статистические наблюдения по инновационным и промышленным кластерам России ведет Российская кластерная обсерватория. Всего в России насчитывается 118 промышленных, инновационных, туристических кластеров и агрокластеров. Основное сосредоточение кластеров приходится на Центральный ФО, Приволжский ФО, Северо-Западный ФО и 
Сибирский ФО. Кроме того, по специализации деятельности кластеры, несомненно, входят в рамки концепции, стратегии и программ развития территорий РФ. Отсюда в сравнении с российскими технологическими платформами выявляется явное пересечение специализаций. И хотя, теоретически правильным является развитие кластеров, а затем только технологических платформ, в данном случае, мы можем заметить, что формирование кластеров происходит практически в параллели с технологическими платформами. И сами кластеры позиционируются как элемент территориального развития, объединяющего в себе усилия государства, промышленности, науки и образования, что очень схоже с технологическими платформами, и этим принципом практически сливаются с платформами, поскольку в российских условиях ведущую долю занимают научный и образовательный сектор.

По официальному сайту геоинформационной системы индустриальных парков, технопарков и кластеров, мы смогли выявить, что на данный момент насчитывается 232 индустриальных парков, 65 технопарков, которые действуют, создаются или планируются. Основная концентрация технопарков приходится на Центральный ФО, Приволжский ФО и Уральский ФО.

На Дальнем Востоке существует 2 технопарка: Технопарк Якутия и Технопарк современных строительных технологий в Сахалинской области [45].

В России наукограды считаются достаточно эффективными и результативными системами, объединяющие различные социальноэкономические объекты для коммерциализации научно-исследовательских результатов с высокой долей самоуправления и регулирования. По официальным данным Минобрнауки в России насчитывается 13 наукоградов.

Центры трансфера технологий (ЦТТ) России представлены университетами, академиями, инновационными агентствами, фондами, которые 
обеспечены необходимыми условиями для выполнения задач по развитию, продвижению и доведению инноваций, разработанных различными научными организациями до коммерческого использования, а также центрами, созданными при университете или отдельно, специализированно на трансфер технологий. Всего существует 102 научных центра, выполняющих функцию ЦТТ.

В России признано незначительное количество государственных научных центров и ведущее место в научно-исследовательской деятельности занимает Российская академия наук, разделенная на 13 отделений по научно-отраслевому признаку и 3 региональных отделения. Кроме того, существуют национальные исследовательские университеты, в число которых входят 29 государственных университетов. Всего научно-исследовательских институтов насчитывается более 1800 институтов.

В России насчитывается 53 инновационных, инвестиционных и венчурных фондов, занимающихся финансированием инновационных проектов на рискованных (начальных) стадиях. Основное размещение подобных организаций приходится на Москву и Санкт-Петербург. Статистические данные по существующим фондам РФ представлены в реестре фондов поддержки научной, научно-технической, инновационной деятельности Минобрнауки.

Не менее важным элементом в инновационной инфраструктуре являются организации, обеспечивающие безопасную и надежную систему продажи, отчуждения, лицензирования результатов интеллектуальной собственности. В России впервые в 2018 году появилась национальная биржа интеллектуальной собственности «IPEX», разработанная под руководством Ассоциации TPChain, которая является национальным координационным центром обработки транзакций с правами и объектами интеллектуальной собственности. Открытие биржи стало новым шагом в обеспечении 


\section{СТРАТЕГИЯ НАУЧНО-ТЕХНОЛОГИЧЕСКОГО РАЗВИТИЯ РОССИИ: ПРОБЛЕМЫ И ПЕРСПЕКТИВЫ РЕАЛИЗАЦИИ}

взаимодействия между представителями интеллектуальной собственности и их потенциальными покупателями.

Кроме того, функционируют и другие биржи, такие как биржа интеллектуальной собственности Ideas Cloud, IP-Maris, 3АО «ВЭБИС». Также особое значение в данной области имеют базы данных интеллектуальной собственности, которые позволяют запатентовать и защитить объекты интеллектуальной собственности. В России соответствующие базы данных имеют Роспатент, Российское лицензионное сообщество, Федеральный институт промышленной собственности, Российский союз правообладателей, Всероссийская организация интеллектуальной собственности [25].

Следовательно, оценка инновационной инфраструктуры PФ свидетельствует, что Россия, несомненно, стремится к развертыванию инновационной и научно-исследовательской деятельности, постепенно расширяя и наращивая свой потенциал в различных аспектах. Если говорить о структуре инновационной инфраструктуры, то она представлена различными типами организаций, которые неотъемлемы в инновационной модели экономике. Правительство РФ подходит всесторонне к развитию элементов инновационной инфраструктуры, пытаясь улучшать условия, как для научнообразовательного сектора, так и для предпринимательского и промышленного.

В оценке исследовательского и предпринимательского потенциала, мы убедились, что отмечается упадок, начиная с 2014 года, что выражается в снижении показателей, рассмотренных в ходе исследования. Человеческий потенциал России в плане исследовательского аспекта находится на среднем уровне в сравнении с развитыми странами мира, предпринимательский же сектор находится на низком уровне и требует наращивания оборотов, так и в целом мотивации инициатив.

Результаты исследования научно-технологического и инновационного потенциала России представлены в виде схемы тенденций и потенциалов к 


\section{СТРАТЕГИЯ НАУЧНО-ТЕХНОЛОГИЧЕСКОГО РАЗВИТИЯ РОССИИ: ПРОБЛЕМЫ И ПЕРСПЕКТИВЫ РЕАЛИЗАЦИИ}

формированию платформ на рис. 27. На данном рисунке мы подчеркнули обобщающие выводы в каждой части исследования и выделили перспективу к формированию новой потенциальной платформы.

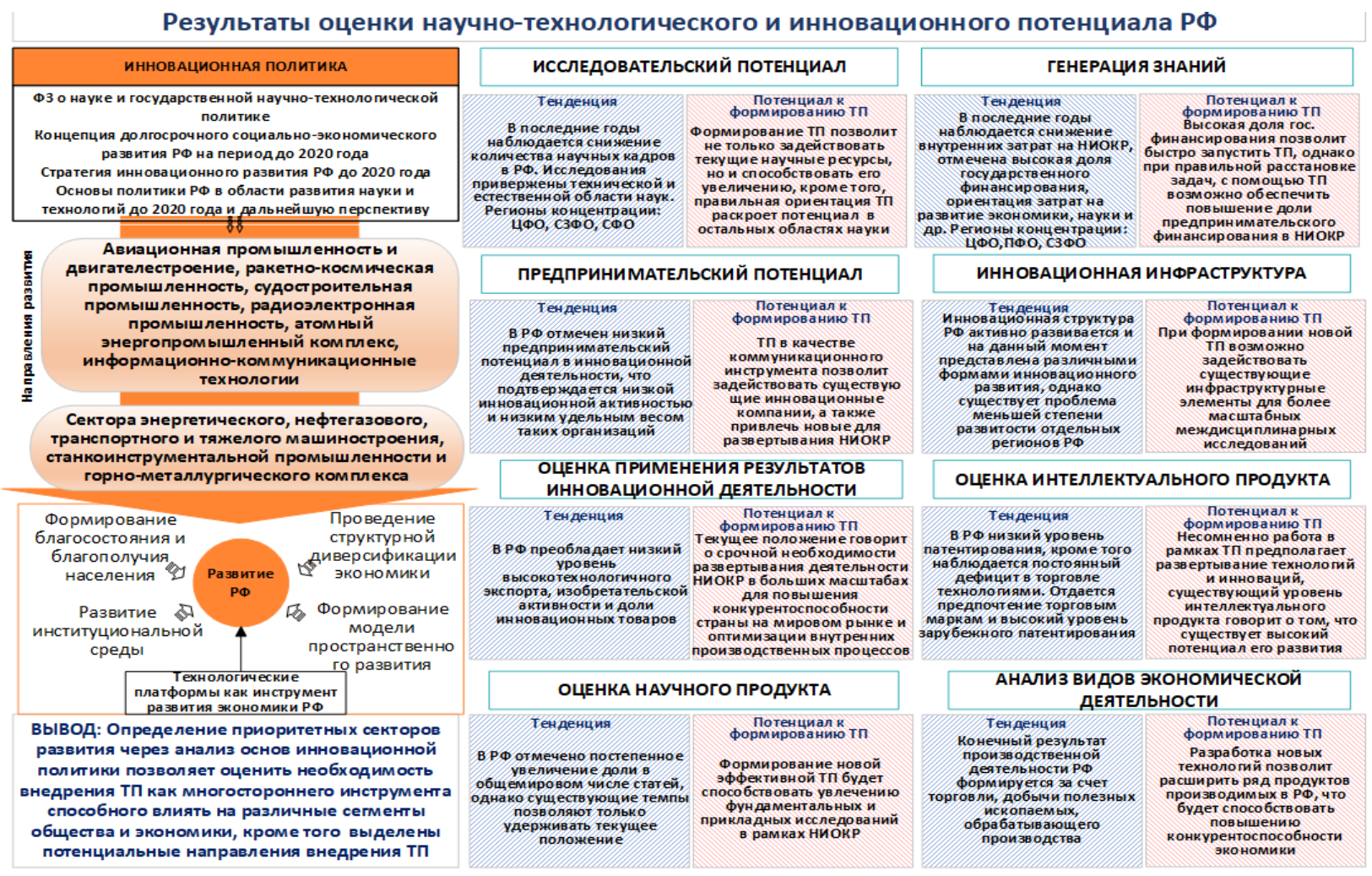

Источник: составлено автором

\section{Рис. 27. Результаты оценки научно-технологического потенциала РФ}

В целом по итогам анализа, в основу которого была положена собственная методика оценки научно-технологического и инновационного потенциала РФ, следует отметить, что на текущий момент по большинству показателей в России наблюдается отрицательная динамика. Данная ситуация заставляет обратить внимание на то, что существуют некоторые барьеры или неэффективность некоторых существующих инструментов, которые тормозят развитие и наращивание мощностей, а также какой существенный вклад в сложившуюся ситуацию способны внести платформы в развитие научнотехнологического и инновационного потенциала России. 


\section{Список литературы}

1. Дежина, И.Г. Технологические платформы и инновационные кластеры: вместе или порознь? / И.Г. Дежина. - М. : Издательство Института Гайдара, 2013. - 124 с.

2. Presentation of European Technology Platform [Электронный pecypc] / European Commission, Directorate General for Research \& Innovation, 2009. - P. 8. - Электрон. дан. - Режим доступа: https://ec.europa.eu/docsroom/documents/ 34962/attachments/1.

3. Лукша, О. П. Европейские технологические платформы: возможности использования европейского опыта для создания нового инструмента содействия инновационному развитию российской экономики / О. П. Лукша // Инновации. - 2010. - № 9. - С. 34-41.

4. Fourth status report on European Technology Platforms: Harvesting the Potential [Электронный ресурс] / European Commission, Directorate General for Research \& Innovation, 2009. - P. 128. - Электрон. дан. - Режим доступа: http://ec.europa.eu/investinresearch/pdf/download_en/etp_status_IV_small_ version.pdf.

5. Evaluation of the European Technology Platforms (ETPs). Finally Report [Электронный ресурс] / IDEA Consult, 2008. - P. 148. - Электрон. дан. - Режим доступа: https://ec.europa.eu/research/evaluations/pdf/archive/fp6-evidence-base/ evaluation_studies_and_reports/evaluation_studies_and_reports_2008/evaluation_of_ the_european_technology_platform_2008.pdf.

6. Assessment of EU FP contribution to ETAP. Final Report [Электронный pecypc] / European Commission, 2013. - Р. 39. - Электрон. дан. - Режим доступа: http://ec.europa.eu/smartregulation/evaluation/search/download.do;jsessionid=D08w TTHRyXcj1qd6k7fBLRPqGnbLsRZZ59nTx9dnnpDVbSLspQNL!1601440011?docu mentId $=2657$. 
7. Commission staff working document: Report on European Technology Platforms and Joint Technology Initiatives: Fostering Public-Private R\&D Partnerships to Boost Europe's Industrial Competitiveness [Электронный pecypc] / Commission of the European Communities, 2005. - Р. 21. - Электрон. дан. Режим доступа: https://ec.europa.eu/research/fp7/pdf/tp_report_council.pdf.

8. Seventh FP7 Monitoring Report [Электронный pecypc] / European Commission, Directorate General for Research \& Innovation, 2013. - P. 174. Электрон. дан. - Режим доступа: http://ec.europa.eu/research/evaluations/ pdf/archive/fp7_monitoring_reports/7th_fp7_monitoring_report.pdf.

9. European Technology Platforms 2020 - DRAFT STRATEGY [Электронный ресурс] / European Commission, Directorate General for Research \& Innovation, 2013. - P. 5. - Электрон. дан. - Режим доступа: http://www.industrialsafety-tp.org/filehandler.ashx?file=12346.

10. Commission staff working document: Strategy for European Technology Platforms: ETP 2020 [Электронный ресурс] / European Commission, 2013. - P. 8. - Электрон. дан. - Режим доступа : http://nanofutures.eu/sites/default/ files/SWD_2013_272_F1_STAFF_WORKING_PAPER_EN_V2_P1_735480.pdf.

11. Густап, Н. Н. Европейские технологические платформы: понятие, история создания, характеристика / Н. Н. Густап // Известия ТПУ. - 2012. № 6. - С. 56-59.

12. Вархолова, Т. Стратегии Европейского Союза : акцент на конкурентоспособности / Т. Вархолова, Л. Дубовицка // Научный диалог. 2015. - № 1. - С. 160-170.

13. Волостнов, Б.И. Технологические платформы - инструмент технологической модернизации и инновационного развития экономики: мировой опыт и пилотные проекты России / Б.И. Волостнов, А.А. Кузьмицкий, В.В. Поляков // Проблемы машиностроения и автоматизации . - 2011. - № 4. C. $22-40$. 
14. Аналитическая справка «Европейские технологические платформы» [Электронный ресурс] / Евразийская экономическая комиссия. Департамент промышленной политики. - Москва, 2012. - 11 с. - Электрон. дан. - Режим доступа: http://www.eurasiancommission.org/ru/act/prom_i_agroprom/dep_prom/ SiteAssets/Европейские технологические платформы.pdf.

15. Стерлигов, И. Национальные технологические платформы. Европейский опыт / И. Стерлигов // Acta Naturae. - 2010. - № 4. - С. 12-13.

16. Волкова, И.О. Сравнительный анализ состояния развития технологических платформ в Европейском Союзе и российской Федерации / И.О. Волкова, Е.Д. Бурда // Вестник ЮУрГУ. Серия «Экономика и менеджмент». - 2016. - № 4. - С. 66-77.

17. Фролов, Д.П. Перспективы адаптации института европейских технологических платформ в России (на примере нбик-конвергентных технологий) / Д.П. Фролов, М.М Бабкин., И.Д. Полынцев // Национальные интересы: приоритеты и безопасность. - 2016. - № 4. - С. 27-39.

18. Era-Learn: Joint Technology Initiatives [Электронный pecypc]. Электрон. дан. - Режим доступа: https://www.era-learn.eu.

19. Annual Activity Report [Электронный pecypc] / European Commission, Directorate General for Research \& Innovation, 2015. - P. 111. - Электрон. дан. Режим доступа: https://ec.europa.eu/info/sites/info/files/activity-report-2015-dgrtd_april2016_en.pdf.

20. Commitment and Coherence - Ex-Post Evaluation of the 7th EU Framework Programme [Электронный pecypc] / European Commission, Members of the High-Level Expert Group, 2015. - Р. 124. - Электрон. дан. - Режим доступа: https://ec.europa.eu/research/evaluations/pdf/fp7_final_evaluation_expert_ group_report.pdf.

21. Coordinating the Research Framework Programme and the Structural Funds to support Research and Development [Электронный ресурс] / CREST 
Working Group, 2007. - Р. 39. - Электрон. дан. - Режим доступа: http://www.eurosfaire.prd.fr/7pc/doc/1180007094_guidelines_fs_pcrdt_04_05_ 2007.pdf.

22. Strengthening the role of European Technology Platforms in addressing Europe's Grand Societal Challenges. Report of the ETP Expert Group [Электронный ресурс] / European Commission, Directorate General for Research \& Innovation, 2010. - P. 98. - Электрон. дан. - Режим доступа: http://www.manufuture.org/wp-content/uploads/ETPs_and_Grand_Challenges_ 03.07.10_FA_IndustrialResearchB5FullPublicationRP_web.pdf.

23. О формировании приоритетных евразийских технологических платформ [Электронный ресурс] : Распоряжение совета Евразийской Экономической Комиссии от 18 октября 2016 г. № 32. - Электрон. дан. - Режим доступа : http://www.eurasiancommission.org/ru/act/prom_i_agroprom/dep_prom/.

24. Об утверждении Положения о формировании и функционировании евразийских технологических платформ [Электронный ресурс] : Решение Евразийского межправительственного Совета от 13 апреля 2016 г. № 2. Электрон. дан. - Режим доступа : http://bibl.laser.nsc.ru/download/laserinform/581all-2.pdf.

25. Официальный сайт Евразийской экономической комиссии [Электронный pecypc]. - Электрон. дан. - Режим доступа: http://www.eurasiancommission.org.

26. Презентация «Евразийские технологические платформы» [Электронный ресурс] / Евразийская экономическая комиссия. - Москва, 2017. - 56 с. - Электрон. дан. - Режим доступа: http://eurasian-studies.org/ archives/6248.

27. Technology Development Foundation of turkey [Электронный ресурс]. Электрон. дан. - Режим доступа : https://ttgv.org.tr. 
28. ETP: European Technology Platforms -A challenge for Turkey's strategic innovation agenda [Электронный ресурс]. - Электрон. дан. - Режим доступа : https://www.journalagent.com.

29. Scientific and Technological Research Council of Turkey [Электронный peсурс]. - Электрон. дан. - Режим доступа : http:// www.tubitak.gov.tr.

30. Turkish Constriction Technology Platform's Official Page [Электронный pecypc]. - Электрон. дан. - Режим доступа : http://www.tctp.org.tr/index.cfm.

31. О Концепции долгосрочного социально-экономического развития Российской Федерации на период до 2020 года [Электронный ресурс] : Распоряжение Правительства РФ от 17 Ноября 2008 г. № 2227-р. : [ред. от 28.09.2018]. - Электрон. дан. - Режим доступа : https://ido.tsu.ru/normdocs/ dpo/2020.pdf.

32. Доклад Межкомиссионной рабочей группы по вопросам модернизации промышленности [Электронный ресурс] / Общественная палата Российской Федерации. - Москва, 2010. - 54 с. - Электрон. дан. - Режим доступа : https://www.oprf.ru/files/olimp/iso/tp/otchet.pdf.

33. Об утверждении Стратегии инновационного развития Российской Федерации на период до 2020 года [Электронный ресурс] : Распоряжение Правительства РФ от 08 Декабря 2011 г. № 1989-р. : [ред. от 18.10.2018]. Электрон. дан. - Режим доступа : http://docs.cntd.ru/document/902317973.

34. Обзор «Российские технологические платформы» [Электронный ресурс] / Минэкономразвития России. - Москва, 2018. - 72 с. - Электрон. дан. Режим доступа : https://nangs.org/docs/minekonomrazvitiya-rossii-obzor-rossijskietekhnologicheskie-platformy-ot-11-01-2018-g-pdf.

35. Официальный сайт технологической платформы «Освоение Океана» [Электронный pecypc]. - Электрон. дан. - Режим доступа: http://oceanplatform.ru. 
36. Аналитическая справка «Российские технологические платформы (РТП), переход от РТП к Евразийским технологическим платформам» [Электронный ресурс] / Евразийская экономическая комиссия. Департамент промышленной политики. - Москва, 2011. - 12 с. - Электрон. дан. - Режим доступа: http://www.eurasiancommission.org/ru/act/prom_i_agroprom/dep_prom/ SiteAssets/Российские технологические платформы.pdf.

37. Об утверждении приоритетных направлений развития науки, технологий и техники в Российской Федерации и перечня критических технологий Российской Федерации [Электронный ресурс] : Указ Президента РФ от 7 июля 2011 г. № 899. Электрон. дан. - Режим доступа : http://economy.gov.ru/minec/activity/sections/innovations/formation.

38. Базовый доклад к обзору ОЭСР национальной инновационной системы РФ «Национальная инновационная система и государственная инновационная политика РФ» [Электронный ресурс] / Министерство образования и науки РФ. - М. : 2009. - 206 с. Электрон. дан. - Режим доступа : https://www.ifap.ru/library/book449.pdf

39. OECD Statistic data Main Science and Technology Indicator 2018 [Электронный pecypc] / OECD Publishing, 2019. - P. 90. - Электрон. дан. Режим доступа : https://www.oecd-ilibrary.org/content/publication/msti-v2018-1-en.

40. Официальный сайт Службы государственной статистики [Электронный ресурс]. - Электрон. дан. - Режим доступа: http://www.gks.ru.

41. OECD Statistic [Электронный pecypc]. - Электрон. дан. - Режим доступа : https://stats.oecd.org.

42. Индикаторы науки: 2019 : статистический сборник [Электронный ресурс] / Л. М. Гохберг, К. А. Дитковский, Е. Л. Дьяченко и др.; Нац. исслед. ун-т «Высшая школа экономики». - М. : НИУ ВШЭ, 2019. - 328 с. - Электрон. дан. - Режим доступа : https://www.hse.ru/data/2018/12/11/1144786145/ niio2019.pdf. 
43. Наука. Технологии. Инновации: 2019 : краткий статистический сборник [Электронный ресурс] / Н.В. Городникова, Л.М. Гохберг, К.А. Дитковский и др.; Нац. исслед. ун-т «Высшая школа экономики». - М. : НИУ ВШЭ, 2019. - 84 с. - Электрон. дан. - Режим доступа : https://www.hse.ru/data/2019/05/07/1502498137/in2019.pdf

44. Карта инновационной экосистемы России [Электронный ресурс]. Электрон. дан. - Режим доступа: http://www.innovation-ecosystem.org.

45. Официальный сайт геоинформационной системы индустриальных парков, технопарков и кластеров [Электронный ресурс]. - Электрон. дан. Режим доступа: https://www.gisip.ru. 
УДК 330.322.2

Глава 2.

РАЗВИТИЕ ЧЕЛОВЕЧЕСКОГО ПОТЕНЦИАЛА - ВАЖНЕЙШЕЕ УСЛОВИЕ ОБЕСПЕЧЕНИЯ ЭКОНОМИЧЕСКОЙ БЕЗОПАСНОСТИ ОРГАНИЗАЦИИ В УСЛОВИЯХ ПАНДЕМИИ

\author{
Чумаков Александр Александрович
}

д. эконом. н., профессор

Ковалева Инна Евгеньевна

магистрант

Назаренко Ирина Михайловна

магистрант

Южнороссийский институт - филиал Российской академии народного хозяйства и госслужбы при Президенте РФ

Аннотация: В условиях возрастания рисков деятельности отечественных предприятий в условиях пандемии подчеркивается значимость персонала, как основного ресурса организации, от которого зависит состояние её экономической безопасности. Отличительная особенность авторского подхода данного исследования обусловлена тем, что во главу развития человеческого потенциала поставлены аспекты развития коммуникации и психологии, способствующие развитию кадрового потенциала и, как следствие, экономической безопасности всего предприятия.

Ключевые слова: экономическая безопасность предприятия, кадровый потенциал, управления персоналом, пандемия, рынок труда. 


\title{
HUMAN DEVELOPMENT ACTIVITIES ARE THE MOST IMPORTANT CONDITION FOR ENSURING THE ECONOMIC SECURITY OF AN ORGANIZATION IN A PANDEMIC
}

\section{Chumakov Alexander Alexandrovich Kovaleva Inna Evgenievna Nazarenko Irina Mikhailovna}

\begin{abstract}
In the context of increasing risks of the activities of domestic enterprises in the context of a pandemic, the importance of personnel as the main resource of the organization, on which the state of its economic security depends, is emphasized. A distinctive feature of the author's approach of this study is due to the fact that aspects of the development of communication and psychology that contribute to the development of human dominate the development of human potential resources, and, as a consequence, the economic security of the entire enterprise.
\end{abstract}

Key words: economic security of the enterprise, personnel potential, personnel management, personnel management, labor market.

\section{ВВЕДЕНИЕ}

В эпоху глобализации, когда экономики всех стран мира становятся всё более сложными и претерпевают структурные изменения, а потребители - всё более требовательными, избирательными, бизнесы и всевозможные организации, а также люди, в них работающие, сталкиваются с более серьёзными трудностями, чем когда-либо прежде. Наибольшую трудность на организационном уровне формируют вопросы экономической безопасности и её обеспечения, способность организации противостоять угрозам внешней 
среды и использовать её вызовы. В основе обеспечения безопасности стоят люди, сотрудники, которые в современных реалиях рассматриваются не только как набор определённых навыков, но и как творческая единица, которой необходимо постоянно развиваться и совершенствоваться в целях обеспечения основных запросов и потребностей как самой личности, так и, важнее в контексте управления предприятия.

Актуальность выбранной темы обусловлена значимостью персонала в организации, как ресурса, от которого зависит реализация многих эконмических факторов на предприятии, в том числе факторов экономической безопасности.

\section{1 КОНЦЕПТУАЛЬНЫЕ ОСНОВЫ РАЗВИТИЯ ЧЕЛОВЕЧЕСКОГО ПОТЕНЦИАЛА СОВРЕМЕННОЙ ОРГАНИЗАЦИИ}

На современном этапе общественного развития экономика поступательно движется вперед за счет способности управлять информацией, технологиями, возможности приобретать знания и умения, которые отвечают современным тенденциям, законам рынка, потребностям социума. Это требует от сотрудников не только обладать необходимым набором компетенций и навыков, но и от работодателя пересматривать своё отношение к человеческим ресурсам, кадровой безопасности и политике управления персоналом. В современном менеджменте работник воспринимается работодателем как единое целое с его психоэмоциональным состоянием (совокупностью эмоций и чувств, переживаемых работником, его выгоранием, потенциалом, способностью реагировать на стресс, решать конфликты и другое). В организациях создаются подразделения по работе с персоналом, которые реализуют функции кадрового менеджмента на системной основе, включая стратегическое управление человеческими ресурсами, профессиональное 


\section{СТРАТЕГИЯ НАУЧНО-ТЕХНОЛОГИЧЕСКОГО РАЗВИТИЯ РОССИИ: ПРОБЛЕМЫ И ПЕРСПЕКТИВЫ РЕАЛИЗАЦИИ}

развитие, совершенствование программ удержания персонала. И именно такие подразделения постепенно «вытесняют» традиционные (классические) отделы кадров, занимающиеся в основном вопросами кадрового делопроизводства.

В современных реалиях сотрудник — это не просто исполнитель, не просто подчинённый элемент в организационной системе, это творческая личность, обладающая отличительными способностями (творческими, организаторскими, аналитическими), интересами и потребностями. А одна из главных задач компании в целях обеспечения кадровой безопасности как неотъемлемого элемента экономической безопасности - это развитие человеческого потенциала каждого сотрудника. Рассмотрим подробнее, что такое управление персоналом, какие цели оно преследует и каким образом грамотное управление персоналом позволяет развивать человеческий потенциал как отдельной личности, так и всего кадрового состава.

В контексте исследования под управлением персоналом понимается целенаправленная деятельность руководства высшего уровня и функциональных руководителей в аспекте разработки и реализации кадровой стратегии (стратегии формирования, использования, развития, удержания, оптимизации человеческих ресурсов), с одной стороны, и текущая деятельность кадровой службы, основная функция которой — реализация кадровой политики для решения следующих задач: заполнения вакантных рабочих мест, развития трудового потенциала, управления эффективностью труда, оптимизации движения и перемещения персонала, с другой стороны [1].

Функция управления персоналом отражает все аспекты относительно того, как комплектовать штат, использовать человеческие ресурсы, занятые в организации и развивать трудовой потенциал в соответствии с текущими корпоративными задачами и будущими изменениями. В частности, она включает такие компоненты, как:

1. Стратегическое управление персоналом; 
2. Кадровое планирование (стратегическое и тактическое планирование потребности в персонале);

3. Проектирование системы управления персоналом;

4. Подбор, отбор и наём персонала;

5. Управление производительностью труда;

6. Управление человеческим капиталом, профессиональное развитие;

7. Управление вознаграждением персонала, совершенствование системы оплаты труда;

8. Развитие трудовых отношений;

9. Мотивация и стимулирование трудовой деятельности;

10. Безопасность труда;

11. Трудовую дисциплину;

12. Документационное сопровождение функции управления персоналом — процедур отбора, найма, профессионального развития, движения персонала (кадровое делопроизводство).

В дополнение к вышеперечисленным основным компонентам, функции управления персоналом включает следующие действия: анализ рынка труда; сопровождение работников (профориентация, адаптация, организация рабочего места и рабочего пространства); организация труда (организация трудовых процессов, нормирование труда, определение оптимального чередования режимов труда и отдыха); развитие социально-трудовой этики; формирование конструктивного социально-психологического климата, управление конфликтами и стрессами; совершенствование кадровых технологий и внедрение нововведений в аспекте кадровой работы; управление кадровыми рисками; создание условий для рационализаторской и изобретательской деятельности; обеспечение трудовых гарантий и реализация принципов социального партнёрства. 


\section{СТРАТЕГИЯ НАУЧНО-ТЕХНОЛОГИЧЕСКОГО РАЗВИТИЯ РОССИИ: ПРОБЛЕМЫ И ПЕРСПЕКТИВЫ РЕАЛИЗАЦИИ}

Рассмотрим далее понятия «объект» и «субъект» в управлении персоналом. Наёмные работники (руководители, функциональные специалисты, рабочие, занятые в основных и вспомогательных процессах) являются объектом управления персоналом: на них направлена реализация функций управления персоналом (формирование и развитие трудового потенциала, мотивационная политика, регулирование трудовых споров и межличностных взаимоотношений). Дополнительно к объекту управления персоналом относятся и сотрудники, занятые на условиях внештатного совместительства, в отдельных ситуациях - сезонные работники (занятые на условиях срочных трудовых договоров), а также лица, периодически выполняющие отдельные трудовые функции на условиях гражданско-правовых договоров. Особая важность состоит в воздействии на группу работников, так как будучи объектом управления, они формируют друг с другом определённый тип взаимоотношений, который может использоваться организацией для достижения общих производственных целей и экономической безопасности.

Что касается субъектов, то ими также выступают люди, напрямую задействованные в структурах управления персоналом и выполняющие соответствующие функции воздействия на персонал для достижения поставленных целей. Это могут быть специалисты службы управления персоналом, менеджеры по персоналу, руководители разных уровней, чьими должностными обязанностями является осуществление функций по управлению персоналом. На этой основе очевидно разграничение уровней субъект-объект и одновременно их конвергентность. Так, например, одно и то же лицо (руководитель) выступает объектом управления персоналом по отношению к собственникам организации (речь идёт о коммерческой организации), поскольку речь и выполнении задач и обязательств перед собственником со стороны руководителя. С другой стороны, этот же руководитель рассматривается в качестве субъекта управления персоналом, 
поскольку наделён полномочиями применять методы управления персоналом для достижения целей организации. Поэтому на том уровне, на котором речь идёт о применении инструментария воздействия на сотрудников, воздействующее (управляющее) лицо выступает субъектом, лицо, подвергаемое воздействию (управляемое) - объектом. На том уровне, на котором речь идёт о коллективном или межличностном взаимодействии (сотрудничестве) на равноправной основе, все участники выступают субъектами в трудовом процессе.

И объект, и субъект в рамках управления персоналом наделены человеческим потенциалом. Анализ литературы позволил выявить несколько определений человеческого потенциала (ЧП). Последние можно свести к совокупности физических и духовных сил человека, которые он может использовать как в своих интересах, так и общества (государства); далеекоторые могут быть приведены в действие и использованы для решения определенных задач и достижения поставленных целей; основополагающих прав, способностей и возможностей индивида, уровень развития и реализации которых способны повысить (или понизить) продуктивность жизнедеятельности общества и т.д. [2]. Обе стороны (и объект, и субъект) взаимодействуют между собой с позиции возможностей своего человеческого потенциала, исходя из опыта, полномочий, способностей, культурных ценностей.

В тоже время отмеченные определения ЧП по сути мало чем отличаются друг на друга, выступая качественными характеристиками сущности ЧП. Что однако не позволяет обеспечить переход к разработке и практическому применению объективных количественных (числовых) оценок величины этого показателя (или системы показателей) для соответствующих теоретических исследований, обобщений и практического применения, в частности, для сравнительного анализа и контроля тех или иных возможностей разных 
работников и трудовых коллективов предприятий с целью повышения качества, результативности и эффективности их работы.

Определив отношения объекта и субъекта управления персоналом, сформируем цель управления персоналом: обеспечение организации конкурентоспособными кадрами, их эффективное использование, профессиональное и социальное развитие, обеспечение общей безопасности предприятия посредством формирования сплочённого трудового коллектива в форме единой команды. Руководствуясь данной целью, в организации возможно создание система кадрового управления, в основе которой формируются закономерности, принципы и методы, разработанные наукой и апробированные практикой.

Дело в том, что развитие человеческого потенциала и закономерности управления персоналом- объективно существующие необходимые связи явлений, внутренние существенные взаимосвязи между причиной и следствием, устойчивые отношения между явлениями, связанными с управлением персоналом, взаимоотношениями между людьми и накладывающими значительные отпечаток на их характер.

Целесообразно выделение основных закономерностей, на основе которых специалисты могут предъявлять объективные требования к системе и алгоритму кадрового управления формирования:

1. Реализация принципа единства системы управления кадрами с развитием человеческого потенциала, целями, спецификой и тенденций развития производственно-эконмической системы.

2. Нахождение оптимального взаимодействия централизации с децентрализаций управления персоналом и развитием человеческого потенциала.

3. Развитие человеческого потенциала и формирование системы управления персоналом на основе принципа системности. 


\section{СТРАТЕГИЯ НАУЧНО-ТЕХНОЛОГИЧЕСКОГО РАЗВИТИЯ РОССИИ: ПРОБЛЕМЫ И ПЕРСПЕКТИВЫ РЕАЛИЗАЦИИ}

4. Наличие принципа пропорциональности между производством и управлением.

5. Включение системой управления персоналом и развития человеческого потенциала в свои методы разнообразные практики и постоянно совершенствование их.

6. Упрощение структуры системы управления персоналом и развития человеческого потенциала путём минимизации числа ступеней [3].

Перечисленные выше закономерности обязательно должны быть учтены в системе управления персоналом организации, так как при взаимодействии они влияют друг на друга и создают интегрированную результирующую силу, что способствует достижению эффекта синергии.

Помимо этого, управление персоналом и развитие человеческого потенциала тесно взаимосвязано с кадровой политикой организации и принципами экономической безопасности. Важно учитывать, что в связи с тенденциями глобализации и всеобщей информатизации, требования предъявляются не только к компетенциям работника, но и к самой кадровой политике. Такого мнения придерживается Демьянова О. [4]. В своей статье она упоминает, что цель кадровой политики предприятий должна состоять в достижении такого состояния, при котором слияние усилий всех работников приведёт к достижению предприятием намеченных целей развития и обеспечения экономической безопасности. На её формирование влияют внешние и внутренние факторы. Наряду с такими внешними факторами, как ситуация на рынке труда, нормативно-правовая среда, на кадровую политику оказывают влияние и тенденции экономического развития, и научнотехнический прогресс, которые направленны на повсеместное внедрение инструментов цифровой экономики (большие данные, Интернет вещей, блокчейн, интеллектуальные информационные технологии). 


\section{СТРАТЕГИЯ НАУЧНО-ТЕХНОЛОГИЧЕСКОГО РАЗВИТИЯ РОССИИ: ПРОБЛЕМЫ И ПЕРСПЕКТИВЫ РЕАЛИЗАЦИИ}

Стремление к цифровизации и закрепление тенденции на общегосударственном уровне, позволяет автоматизировать процессы кадрового документооборота как в государственном секторе, так и постепенно в коммерческом. Тем самым автоматизация позволяет снять часть «традиционных» функций со службы отдела кадров и добавить на место них новые, например: развитие потенциала, кадровая политика, отбор и подбор, организационная культура и другое. Так «классический» отдел кадров постепенно становится службой управления персоналом, и с изменением представления и функциональных обязанностей другие требования предъявляются и к работникам в цифровой среде.

Рассматривая человека как главную производительную силу общества, отметим, что кадровая политика предприятия, осуществляемая службой управления персоналом, в условиях развития цифровой экономики закладывает следующие характеристики работника в цифровой среде:

Работник - это личность, адаптированная к возможностям и ограничениям цифровой экономики, которая повседневно пользуется благами цифровой экономики, постоянно адаптируется к новым условиям. Работник это человек, ответственно взаимодействующий с цифровым правительством, цифровыми медиаресурсами. Работник - это пользователь, обладающий необходимыми компетентностями для эффективной деятельности к цифровой среде и цифровыми инструментам. Работник - личность, владеющая цифровыми технологиями, использующая их в профессиональной деятельности, ведущейся в цифровой информационной среде организации. Работник - это источник и основа обеспечения экономической безопасности.

Кадровая политика организации в условиях цифровой экономики должна предъявлять требования не только к наличию знаний к информационным технологиям и их применению, но и к наличию компетенций XXI века: творческое мышление, инициативность, ответственность, предприимчивость, 
эмоциональный интеллект. В то же время кадровая политика предприятия в условиях цифровой экономики должна быть способной к функции деятельности работника и объективной оценке её эффективности, развитию его кадрового потенциала. Для этого в организации должны быть разработаны автоматизированные формализованные процедуры и способные к измерению критерии оценивания, должна быть обеспечена возможность оценки развития человеческого потенциала каждого сотрудника с момента его найма на работу.

Кадровые подразделения предприятий, являясь драйвером цифровизации в своей зоне ответственности, должны быть нацелены на принятия решений по внедрению механизмов автоматизации, с учетом запросов работников, бизнеснеобходимости и базируясь на современных трендах. Базовыми элементами подготовки персонала предприятия к цифровой трансформации являются три составляющие: технологическая, образовательная и коммуникационная. Следует постоянно добиваться развития этих направлений, способствуя формированию культуры, как предпосылки гибкости и проактивности сотрудников. Последнее способно создать в организации среду, в которой цифровизация будет проходить наиболее эффективно. А создание среды подтверждает факт эффективности системы управления персоналом, которая также способствует развитию человеческого потенциала.

Bсё перечисленное выше прямо влияет на «HR-бренд» организации, который представляет систему и практики управления персоналом, с помощью которых поддерживаются характеристики «бренда работодателя», транслируемые внутренним и внешним кандидатам через «Ценностное предложение работодателя». Сам «бренд работодателя» успешен в тех случаях, когда его визуал и формальная часть (транслируются внутри компании и за её пределами) соответствует содержанию (содержательные характеристики). Коммуникативные характеристики в данном случае представляют собой технологии и способы передачи информации о содержательных характеристиках и ценностных преимуществах целевой аудитории - группе рынка труда или действующим работникам. 
Содержательные характеристики отражают систему и практики управления персоналом в компании, включая политику и мероприятия в области подбора и адаптации, обучения и развития, вознаграждения персонала, управления карьерой, управления внутренними коммуникациями, организации труда сотрудников, управления трудовыми отношениями. Эффективная система управления персоналом и HR-практик, представляющая собой не что иное, как «HR-бренд», формирует набор уникальных дополнительных ценностей, позволяющих привлекать новых работников и удерживать работающих сотрудников в компании. В общем виде модель влияния и взаимодействия можно представить в виде рисунка 1.1.

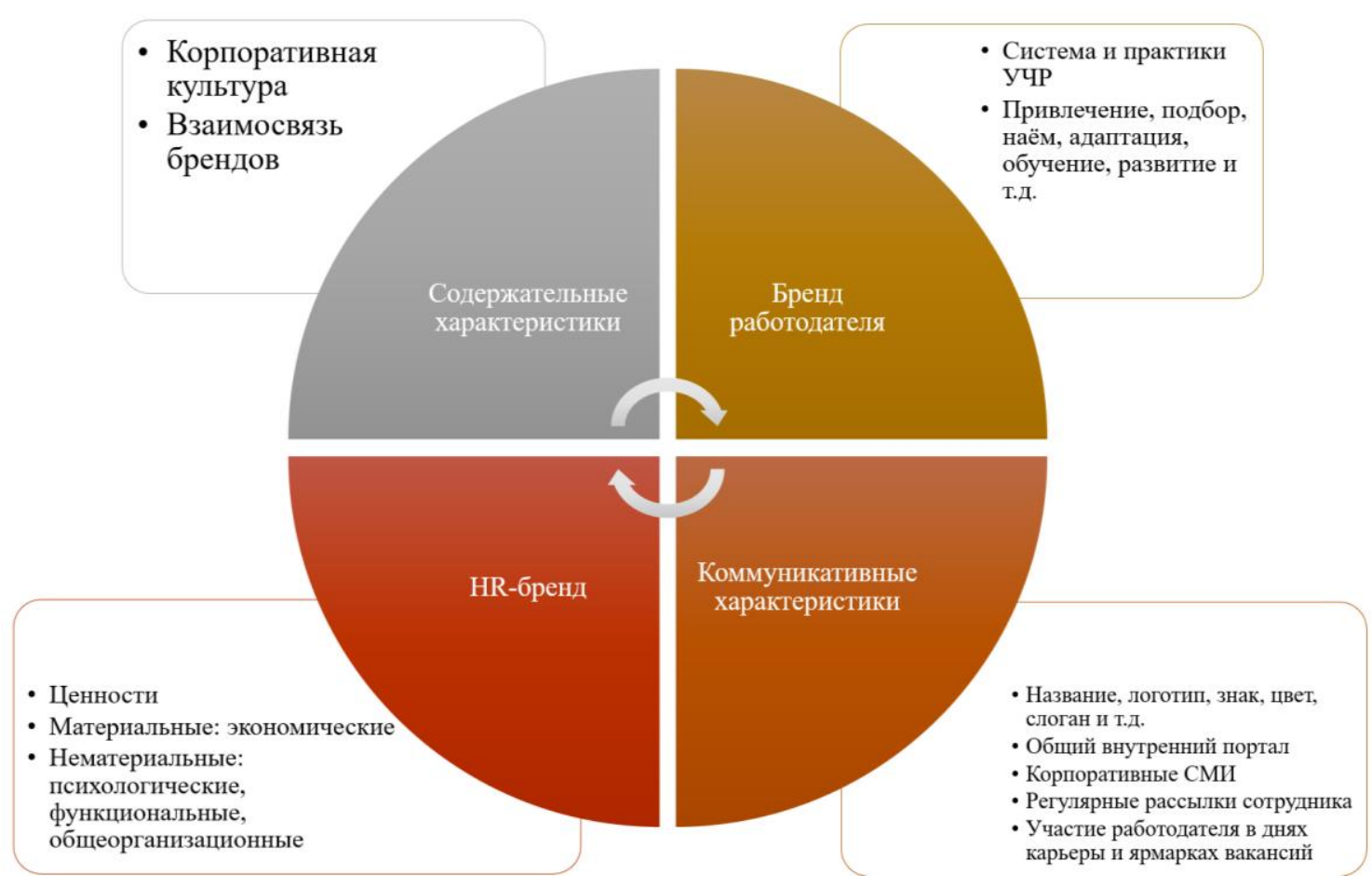

\section{Рис. 1. Модель операционализации бренда [5]}

Также следует отметить, что, несмотря на стремление оценить человеческий потенциал, необходимо понять, что методики его развития строятся на основах психологии и коммуникации. Сотрудник сейчас, как 
упоминалось ранее, - это не только набор необходимых навыков и компетенций, «рабочая сила», но и человек с определённым набором культурных, социальных ценностей, которые могут и не совпадать с ценностями компании. Именно поэтому знание психологии сотрудниками службы управления персоналом позволяют понять каждого отдельного сотрудника, его базовые шаблоны действий (реакции на стресс, к примеру) и использовать эти шаблоны таким образом, чтобы изменить, развить и подстроить под задачи и цели предприятия, а знание основ коммуникации позволяют понять управленцу, как подчинённые сотрудники воспринимают информацию и позволяют построить стратегию так, чтобы донести информацию в полном объёме без искажения её сути и смысла. И психология, и коммуникация лежат в основе развития и понимания человеческого потенциала. А создание и закрепление сильного кадрового состава на предприятии является основой экономической безопасности предприятия, его прочный «фундамент».

\section{2 СОВЕРШЕНСТВОВАНИЕ СИСТЕМЫ УПРАВЛЕНИЯ КАДРОВЫМИ РИСКАМИ}

Важнейшей составляющей любого бизнеса должно быть управление кадровыми рисками независимо от размера или отраслевой принадлежности.

Комплексный план управления рисками необходимо включать в общую дорожную карту успеха бизнеса. Главная производительная сила играет роль ключевого фактора в успешной деятельности организации, это непосредственно распространяется и на сферу минимизации рисков. Компания может выпускать конкурентоспособные продукты или услуги, но, если у неё дефицит квалифицированных, достаточно мотивированных работников, бизнес не выйдет на запланированные рубежи. 


\section{СТРАТЕГИЯ НАУЧНО-ТЕХНОЛОГИЧЕСКОГО РАЗВИТИЯ РОССИИ: ПРОБЛЕМЫ И ПЕРСПЕКТИВЫ РЕАЛИЗАЦИИ}

Согласно предыдущим теоретическим положениям и практическим рекомендациям по использованию инструментария развития человеческого потенциала в условиях продолжающейся пандемии была проведена параллель, согласно которой личная безопасность и перспектива каждого сотрудника на предприятии составляет основу кадровой безопасности, которая в свою очередь входит составным блоком в экономическую безопасность. Однако, как внешняя среда предоставляет угрозы и возможности, так есть и риски, которые могут возникнуть даже при применении озвученного выше инструментария и построения наиболее отвечающей запросам тенденций кадровой политики.

Однако в современных кризисных условиях проблеме нейтрализации рисков в работе с персоналом не придается должного значения, которая обостряется в связи наметившейся общей нехваткой специалистов у ряда компаний, что побуждает их к активному поиску квалифицированных кадров. Как ни странно, но согласно практическому наблюдению за рынком труда на сервисах на некоторых должностях, особенно связанных с WEB-разработкой, сейчас условия диктует не работодатель, а кандидат на должность. Но такая ситуация зависит от должности, на которую претендует соискатель, спроса на неё, предложения и ситуации на рынке. При этом всегда следует учитывать существующую опасность, обостряемую проблемой дефицита квалифицированных работников, возможностью их «переманивания» конкурирующими фирмами. Таким образом, необходимо отличать механизм ранее действующей конкуренции, реализация которого в основном происходила на основе борьбы за покупателей продуктов и услуг. Теперь во главу угла должен быть выдвинут рынок труда, в котором конкуренция за квалифицированных работников по существу модифицируется в «агрессивное сражение».

Следует отметить и различия «страхов» и рисков, охвативших предпринимателей разных сфер деятельности. Так, в деловой сфере чаще всего 
беспокоятся по поводу опозданий и невыходов сотрудников на работу. Другая проблема (например, в ресторанном бизнесе) - низкая работоспособность и недостаток корпоративной этики сотрудников. В финансовом секторе больше всего волнуются по поводу мошенничества, хищения средств со стороны работников. Не менее важной проблемой является снижение мотивации персонала. Так, работодателей гостиничного и ресторанного бизнеса больше всего беспокоит недостаток профессиональных навыков у работников. Меньше всего работодателя заботят межличностные отношения, которые возникают в компании между сотрудниками.

Классификация рисков, предполагающая их разделение на группы по определенным критериям, позволяет оценить место каждого в общей системе и создает потенциальные возможности выбора наиболее эффективных подходящих методов и приемов управления рисками. Предлагаемая классификация кадровых рисков основана на принципах сложности, непрерывности, иерархии, автономности, гибкости. Учитывая локализацию кадровых рисков, они делятся на две большие группы: внешние и внутренние [6]. Внешние кадровые риски - это негативные воздействия внешней среды, которые влияют как на процессы внутри компании в целом, так и на ее кадровую безопасность. Риски для внешнего персонала включают: политические - несовершенство законодательной базы, деятельности общественных организаций, движений, партий и т.д. Экономические инфляционные процессы, сложная ситуация на рынке труда и др. Социальнодемографические. Природно-климатические - наводнения, оползни и другие техногенные факторы. Рыночные (конкурентные) - наличие более привлекательных условий работы для конкурентов, переманивание сотрудников, внешнее давление на сотрудников (взяточничество, шантаж) и т.п. [7]. 


\section{СТРАТЕГИЯ НАУЧНО-ТЕХНОЛОГИЧЕСКОГО РАЗВИТИЯ РОССИИ: ПРОБЛЕМЫ И ПЕРСПЕКТИВЫ РЕАЛИЗАЦИИ}

К внутренним относятся кадровые риски, источники которых находятся внутри организации. Они, в свою очередь, по источникам риска подразделяются на личные риски и риски системы управления персоналом.

К рискам системы управления кадрами целесообразно отнести те, которые дифференцированы по подсистемам системы управления персоналом, например, связанные с планированием и маркетингом персонала; трудовыми отношениями; мотивации персонала; его обучения и развития; условий труда и безопасности, бизнес-оценки персонала; неэффективной организационной структуры; социального развития работников; юридического сопровождения; вплоть до информационной поддержки [8]. В свою очередь, среди рисков персонала можно назвать риск нарушения прав и свобод личности, физическое и психическое насилие на работе, унижение чести и достоинства, риск причинения вреда здоровью, риск потери работы, риск снижения доходов.

Кадровые риски связаны с рисками уменьшения материальных ценностей, потерей информационных ресурсов, формированием негативного имиджа компании и её банкротства. По критерию потенциального ущерба кадровые риски подразделяются на локальные, средние, значительные и глобальные (стратегические) кадровые риски. [9].

Теперь разберём, как же использовать систему кадровой безопасности, в частности совершенствование и развитие человеческого потенциала в контексте обеспечения экономической безопасности, в частности минимизации рисков на предприятие. А начнём с того, что война за персонал «выигрывается» однако не столько денежными предложениями, сколько имеющимися направлениями кадрового менеджмента, связанных с развитием человеческого потенциала. Что укрепляет кадровую безопасность, способствующей минимизации рисков предприятия. Значительных преобразований должна затронуть и модель подбора персонала, сводившаяся к найму с минимальными издержками требуемых специалистов определённого качества для 
удовлетворения не столько текущих, сколько перспективных потребностей компании в компетентном персонале. Зачастую это порождало привлечение нелояльных работников, не соответствующих организационной культуре фирмы, её ценностям. С другой стороны, это связано с риском увольнения сотрудника, лояльного компании и в связи с этим - различного рода потерь [10].

При наборе персонала организации следует избегать как завышения, так и занижения требований, так как в первом случае возможны проблемы с привлечением персонала и разочарование специалистов в предлагаемой работе; а во втором - компания не получит нужного специалиста. Подобное обстоятельство предполагает разграничение обязательных и желательных требований, что достигается применением технологии: «сначала ищем внутри, потом вовне», позволяющей обеспечить соответствие сотрудников не только требованиям должности, но и организационной культуре компании. В результате снижаются риски управления персоналом на основе повышения лояльности сотрудников.

Оценивая данные инструменты в рамках кадровой безопасности необходимо учитывать и ряд других положений, потому напомним только следующее. А именно: с целью минимизации рисков вектор механизма управления профессиональным развитием человеческого потенциала формирования в первую очередь необходимо увязывать с работниками, разделяющих ценности компании. Практика свидетельствует, что даже в кризисных ситуациях (пандемии) только лояльный сотрудник, как правило, поддерживает предприятие, что также уменьшает её потери от возможных рисков [11].

Далее существенным фактором оптимизации кадровой безопасности менеджмента организации является социальный риск. Последний связан с вероятностью возможного неблагоприятного инцидента в будущем и тяжестью 
его последствий, ухудшающий качественные характеристики жизни занятого персонала. Непосредсвенно это можно отнести к современной пандемии. Отмеченный риск непосредственно зависит от конкретных видов человеческой деятельности, и естественно, способен проявляться в разных специфических формах [12]. В данной связи следует подчеркнуть роль использования технологии риск-менеджмента, прошедшую в своём развитии этапы от самострахования до тотального контроля над всеми рисками бизнеса. Совершенствование алгоритма уменьшения рисков в реализации кадровой безопасности предприятия также основан на необходимости исследования психологических аспектов принятия решений, управления профессиональными рисками на основе набора механизмов и институтов по снижению, компенсации и контролю подобных рисков, организации виртуального предприятия, анализа трудового потенциала работников с учётом риска недостижения намеченной цели компанией [13].

Существенную роль играет решение проблемы подбора и отбора кадров при приёме на работу. В поле зрения должны попасть следующие составляющие, такие как «разрешение на проверку личных данных», непосредственно проверка анкет с личными данными, а также «соглашение о неразглашении конфиденциальной информации». С этой целью в состав управления по работе с персоналом должно быть включено подразделение, осуществляющее функции не только службы безопасности, но и комплексного контроля путём изучения предыстории кандидата и другое. Всё это должно находится в основе, разработанной методики управления снижения кадровых рисков. Управление кадровыми рисками - это деятельность, направленная на разработку стратегических и тактических мер по анализу риска, выработки и принятия соответствующих мер для оптимизации управления в условиях риска на всех этапах работы с человеческими ресурсами компании. 
Стратегия управления кадровыми рисками включает в себя несколько этапов. На первом этапе происходит мониторинг различных потенциальных рисков и восприятие их уровня путем анализа угроз и уязвимостей. Анализ позволяет идентифицировать риски по источнику, причине возникновения, намеренности риска, характеру и уровню потерь, потенциальным действиям по реализации риска. Многочисленные исследования показывают, что самое сложное звено в системе безопасности - это человек, так как именно человеческий фактор может оказать критическое влияние на успешность деятельности и само существование компании. В связи с этим рекомендуется выделение двух основных направлений в области кадровой безопасности, связанных с развитием человеческого потенциала:

1. Охрана и улучшение условий труда сотрудников.

2. Повышение лояльности персонала к своей организации, целью которого должен стать переход от «вынужденной лояльности» к «соответствующей требованиям будущего добровольной лояльности». И именно на второй пункт делается упор, потому что это воздействует на коммуникации, их характер и учитывает психологическое состояние работника. Развитие указанных направлений в контексте управления рисков укрепляет экономическую безопасность и способствует сохранению и развитию человеческого потенциала компании.

Таким образом, до тех пор, пока риск-менеджментом занимаются люди, сотрудники, кадры, и до тех пор, пока человек является основной и движущей силой изменения и обеспечения кадровой безопасности предприятия, руководство должно предпринимать все усилия по анализу и закреплению основных направлений воздействия на развитие и обеспечение лояльности персонала к предприятию. 


\section{Список литературы}

1. Кибанов А.Я. Основы управления персоналом. -М.: Инфра-М.- 2019. C. 14.

2. Кадырова О.В., Мамонова Ю.С. Развитие кадрового потенциала предприятия: принципы, тенденции и проблемы // Экономика и предпринимательство. — 2021. — №. 6. - С. 1370-1375.

3. ЗиннуроваЮ.А. Широнина Е.М. Теоретические аспекты развития кадрового потенциала//Вестник университета. -2019.-№12.- С.20.

4. Валиева О. Д., Демьянова О. В. Цифровая экономика как фактор экономического развития организации // Экономика в меняющимся мире. Казанский (Приволжский) федеральный университет, Казань. -2021.- С.34.

5. Кибанов А.Я. Основы управления персоналом- М.: Инфра-М.- 2019. - C. 42 .

6. Новиков В. В., Огородникова Л.В. Кадровая безопасность в системе экономической безопасности предприятия // Прорывные научные исследования как двигатель науки. - Воронеж. - 2021. - С. 92.

7. Киселев С.В., Поникарова А.С., Кадеева Е.Н. Проблемы управления развитием кадрового потенциала в условиях инновационных промышленных рисков // Экономика и предпринимательство. — 2020. — №. 1. - С. 1066-1069.

8. Киселев С.В., Поникарова А.С., Кадеева Е.Н. Проблемы управления развитием кадрового потенциала в условиях инновационных промышленных рисков // Экономика и предпринимательство. - 2020. — №. 1. - С. 1066-1069.

9. Дудина А.А., Галимова А.Ш. Сохранение и развитие кадрового потенциала в условиях турбулентной (или кризисной) экономики // Глобальная экономика в XXI веке: роль биотехнологий и цифровых технологий. - 2020.С.51-52. 10.Зиннурова Ю.А., Мухина Е.Р. Развитие кадрового потенциала на предприятии // Дневник науки. - 2020. — №. 1. - С. 35. 
10. Еремина И.В. Человеческий капитал как фактор обеспечения экономической и кадровой безопасности в организации // Инновационное развитие экономики. — 2021. — №. 1. - С. 303-305.

11. Димитриева С.Д. Формирование системы развития кадрового потенциала организации // Управление персоналом организации в условиях цифровизации. - 2020. - С. 114-142.

12. Димитриева С.Д. 2.2 Формирование системы развития кадрового потенциала организации // Управление персоналом организации в условиях цифровизации. - 2020. - С. 114-142.

13. Давыдова Ю.С. Развитие кадровой безопасности как инструмент экономической безопасности организации //Форум молодых ученых. - 2021. - №. 3. - С. 35 . 
УДК 316.422

\author{
Глава 3. \\ ОЦЕНКИ ПОТЕНЦИАЛА РАЗВИТИЯ \\ Г. ТЮМЕНИ НА ПУТИ К УМНОМУ ГОРОДУ
}

Данилов Олег Фёдорович

д.т.н., профессор

ФГБОУ ВО «Тюменский индустриальный университет»

Логинов Станислав Игоревич

Департамент информатизации Тюменской области

Лихтенштейн Борис Максимович

к.с.н., доцент

Белоножко Марина Львовна

д.с.н., профессор

ФГБОУ ВО «Тюменский индустриальный университет»

Аннотация: Миграция населения в крупные города - это естественный процесс и мировая тенденция. В России, в большинстве своем, она связана с социально-экономическими причинами: население переезжает из малых городов и сельских поселений с низким уровнем жизни и возможностями для развития и личностного роста в крупные города в стремлении достичь более высокого жизненного уровня, поиске новых возможностей заработка и самореализации.

Естественным результатом воздействия миграционных процессов является повышающаяся нагрузка на инфраструктуру городов, ускорение износа городских сетей, рост дефицита бюджетных ресурсов. Инновационный путь решения комплекса обозначенных проблем обычно описывается 
концепцией «Умный город», реализуемой в настоящее время во многих странах, включая и Россию.

Целью данной работы является анализ существующих возможностей и перспектив развития г. Тюмени, как «умного города».

Ключевые слова: урбанизация, умный город, информатизация городов, качество жизни населения.

\title{
ASSESSMENT OF THE DEVELOPMENT POTENTIAL OF TYUMEN ON THE WAY TO A SMART CITY
}

\section{Danilov Oleg Fedorovich \\ Loginov Stanislav Igorevich \\ Lichtenstein Boris Maksimovich \\ Belonozhko Marina Lvovna}

\begin{abstract}
Migration of the population to large cities is a natural process and a global trend. In Russia, for the most part, it is associated with socio-economic reasons: the population moves from small towns and rural settlements with a low standard of living and opportunities for development and personal growth to large cities in an effort to achieve a higher standard of living, in search of new earning opportunities and self-realization.

The natural result of the impact of migration processes is an increasing burden on the infrastructure of cities, accelerating the deterioration of urban networks, and an increase in the deficit of budget resources. The innovative way of solving the complex of the indicated problems is described by the concept of "Smart City", currently being implemented in many countries, including Russia.

The purpose of this work is to analyze the existing opportunities and prospects for the development of Tyumen as a "smart city".
\end{abstract}

Key words: urbanization, smart city, informatization of cities, quality of life of the population. 
«Умный город» предусматривает обеспечение оперативного сбора, обработки и целевого использования информации, необходимой для управления обо всех процессах жизнедеятельности города. При этом жители, в интересах которых действует муниципалитет, становятся источником информации для корректировки управленческих действий и активными участниками всех происходящих на территории города процессов.

Инструментальные возможности для развития городов в данном направлении появились в последнее десятилетие в связи с бурным развитием информационно - коммуникационных технологий, новых методов работы с большими данными, развития социальных сетей и высокоскоростного интернета, сопровождающихся соответственным удешевлением самих сервисов.

Отличительной чертой «умного города» является ориентация на стратегию долгосрочного устойчивого развития. Под устойчивым развитием подразумеваются решения, направленные на удовлетворение потребностей населения в настоящем, при этом потребности будущих поколений затрагиваться не должны.

В России, основным инвестором в программы развития умных городов является государство. Это подтверждается оценками экспертов НИИТС [1]. Сегодня, 90\% рынка «умных городов» России приходится на безопасность и транспорт, $10 \%$ ресурсов направляется на программы обеспечения энергоэффективности, развитие интернета вещей и промышленного интернета.

Стартовые возможности городов в реализации программы «умный город» существенно различаются. Как правило, используются уже имеющиеся наработки по отдельным направлениям, поэтому, при разработке комплексной программы развития часто наблюдается неоднородность в модернизации по конкретным сферам жизнедеятельности, исходя из представлений о приоритетах. 


\section{СТРАТЕГИЯ НАУЧНО-ТЕХНОЛОГИЧЕСКОГО РАЗВИТИЯ РОССИИ: ПРОБЛЕМЫ И ПЕРСПЕКТИВЫ РЕАЛИЗАЦИИ}

При этом, как отмечают эксперты, универсального эталона «умного города» как в России, но, и на международном уровне, где существует большой опыт модернизации городов в данном направлении, нет [2].

Авторами данной работы был проведен SWOT - анализ, позволивший выделить сильные и слабые стороны в развитии города Тюмени, оценить возможности и угрозы [3]. Полученные результаты послужили исходным материалом для разработки концепции деятельности команды разработчиков.

На втором этапе, был проведен анализ существующей практики использования информационных технологий, являющихся основой умного города, в различных сферах жизнедеятельности.

Тюмень является динамично развивающимся областным центром в Уральском федеральном округе Российской Федерации, численность населения которого неуклонно растет. За последние годы общая численность населения, по данным государственной статистики, увеличилась до 816,8 тыс. человек в 2021 году и администрация прогнозирует, что в обозримом будущем Тюмень станет городом - миллионником. При этом ситуация на рынке труда сохраняется стабильной и активно достигаются показатели, зафиксированные в период до начала пандемии коронавируса. Уровень безработицы по методологии Международной организации труда в марте 2021 г. по Тюменской области составляет $5,2 \%$, в региональном банке вакансий заявлено более 27,5 тыс. свободных рабочих мест.

В течение ряда лет Тюмень является одним из лидеров рейтинга по качеству жизни, который составляют эксперты Финансового университета при Правительстве Российской Федерации, в том числе и на основе мнения жителей. По данным Федеральной службы государственной статистики в г. Тюмени среднемесячная номинальная начисленная заработная плата одного работника в организациях (без субъектов малого предпринимательства) за январь - декабрь 2020 года составляет 66537 руб., и увеличилась, на смотря на 
кризисные явления, связанные с пандемией коронавируса, по сравнению с соответствующим периодом 2019 года на 5,1\%.

По объему инвестиций на душу населения в январе-сентябре 2020 года Тюменская область в 1,7 раза превышала среднероссийский показатель 135,1 тыс. рублей и 81,2 тыс. рублей соответственно. В инвестиционном портфеле Тюменской области более 700 проектов. При полной их реализации планируется создать более 30 тысяч новых рабочих мест.

В рамках реализации ведомственного проекта цифровизации городского хозяйства «Умный город» приказом Минстроя России от 31.12.2019 №924/пр утверждена методика оценки хода и эффективности цифровой трансформации городского хозяйства в Российской Федерации (IQ городов) (далее Методика). Целью индекса IQ городов является оценка и мониторинг хода и эффективности цифровой трансформации городского хозяйства в городах с населением свыше 100 тысяч жителей, формируемого на ежегодной основе. По итогам оценки индекса IQ за 2020 год город Тюмень занял 3-е место, за 2019 год - 2-е место.

Тюменская область входит в один ряд с передовыми регионами страны в сфере развития электронного правительства и информационного общества.

В Рейтинге развития информационного общества Минкомсвязи России, Тюменская область находится в числе лидеров [4]. Развитие информационного общества в Тюменской области осуществляется в рамках выполнения мероприятий профильной государственной программы «Развитие информатизации».

Кроме того, мероприятия по информатизации заложены в 11 крупных отраслевых государственных программах, реализуемых в Тюменской области.

Каждую из программ курирует профильный орган государственной власти. 


\section{СТРАТЕГИЯ НАУЧНО-ТЕХНОЛОГИЧЕСКОГО РАЗВИТИЯ РОССИИ: ПРОБЛЕМЫ И ПЕРСПЕКТИВЫ РЕАЛИЗАЦИИ}

По показателям развития ИКТ инфраструктуры Тюменская область занимает высокие позиции в Российской Федерации.

По численности пользователей сети Интернет на 100 человек населения Тюменская область с показателем 90 в 2020 году занимала 1 место в Уральском федеральном округе (усредненный показатель по РФ - 85). В городе Тюмени и городах юга Тюменской области функционирует региональная сеть бесплатного доступа в Интернет «TyumenFree».

Доля граждан, использующих механизм получения государственных и муниципальных услуг в электронной форме, составляет $72,2 \%$ - 9 место в Российской Федерации и 2 место в УрФО, а уровень удовлетворенности граждан, получаемыми в электронном виде госуслугами, составил 86,2\%.

Активно развивается жилищное строительство. В 2020 г. в Тюменской области введено в эксплуатацию 1 млн 581 тыс. кв. м жилья, что является одним из самых высоких показателей в России.

Современный рынок новостроек г. Тюмени удовлетворяет спрос не только количественно, но и качественно. Все больше появляется «умных домов», оснащенных централизованной системой кондиционирования, современными лифтами, видеодомофонами, системой телеметрии и промышленной очистки воды, горизонтальной разводкой отопления и другими инженерными решениями.

Система «умный дом» позволяет самостоятельно управлять домом через мобильное устройство из любой точки мира. Жильцы могут дистанционно регулировать освещение, тепло, защищать дом от протечек и реагировать на проникновение в квартиру. Все это способствует повышению уровня и качества жизни горожан и стимулирует рост социальных стандартов жизнедеятельности.

Сегодня этот социальный стандарт неразрывно связан с внедрением технологий умного города, которые ориентированы на потребности горожан и 
развиваются в тренде современных представлений о стратегии городского развития.

Рост уровня жизни невозможен без роста уровня комфорта и безопасности. Одно из средств безопасности - это видеонаблюдение за местами общественного пребывания людей.

В рамках внедрения технологий «Умного города» происходит объединение в единую систему всех видов видеонаблюдения и контроля:

1. Подъездное видеонаблюдение;

2. Дворовое видеонаблюдение;

3. Видеонаблюдение мест массового скопления граждан;

4. Видеонаблюдение в образовательных организациях;

5. Видеонаблюдение ярмарок выходного дня и объектов торговли и услуг;

6. Видеонаблюдение в медицинских учреждениях.

В Единый центр хранения и обработки данных систем видеонаблюдения Тюменской области передаются видеоизображения с камер видеонаблюдения, которые расположены в местах массового скопления граждан на территории всей области.

В рамках концепции построения и развития аппаратно-программного комплекса «Безопасный город», утвержденной распоряжением правительства Российской Федерации от 03.12.2014 № 2446-p, в Тюменской области функционируют развиваются следующие системы:

- Система «Единый центр хранения и обработки данных систем видеонаблюдения Тюменской области» (ЕЦХД);

- Система фото-видеофиксации нарушений правил дорожного движения Тюменской области;

- Система взаимодействия экстренных оперативных служб при вызовах по единому номеру «112» в Тюменской области (Система-112); 
- Централизованная информационная система единых дежурнодиспетчерских служб Тюменской области (ИС ЕДДС);

- Региональная автоматизированная система централизованного оповещения населения Тюменской области (РАСЦО);

- Автоматизированная система диспетчерской службы скорой медицинской помощи.

Тюменская область традиционно одна из лучших в стране по уровню здравоохранения: и по общим показателям смертности, и по уровням младенческой смертности, продолжительности жизни.

Доступность врачебной помощи облегчает использование в здравоохранении современных информационных технологий:

- запись на прием к врачу с использованием дистанционных источников: через Интернет, инфокиоски, единый центр записи, мобильное приложение;

- совершенствуется сервис «Личный кабинет пациента», через который удобно записаться на прием к врачу, узнать результаты лабораторных исследований;

— внедрена электронная медицинская карта, которая позволила отказаться от использования бумажных документов;

— появился функционал, позволяющий родителям увидеть результаты обследования детей;

— поликлиники внедряют единый формат навигации;

- внедрение системы управления ресурсами в медицинских учреждениях;

- развивается телемедицина, которая на сегодня включает консультации на уровнях «врач-врач» и «врач-пациент» и дистанционный мониторинг состояния здоровья пациента. Также эта система позволяет хирургам во время операции связываться, не только с аудиторией в конференц-зале, клиники 
наблюдающей за ходом операции, но и коллегами из других городов и стран, в режиме онлайн.

Свыше 87\% медицинских организаций передают сведения электронных медицинских карт пациентов в федеральную систему интегрированной электронной медицинской карты (ИЭМК). Всем медицинским организациям региона доступны системы или комплексы, обеспечивающие оказание телемедицинских услуг, и радиологические информационные системы и/или архивы медицинских изображений.

Таким образом, быстро развивающиеся технологии улучшают работу специалистов и медучреждений в целом, отражаясь на показателях здоровья города и региона, страны в целом.

В «умном» городе, в идеале, не пациент идет к врачу в поликлинику, когда у него что-либо заболело, а медицинский сотрудник, видя отклонения в показаниях пациента, связывается с ним до того момента, как пациент заболел.[5]. Гаджеты, имеющие возможность собирать информацию с носимых медицинских датчиков о состоянии здоровья человека и передавать их лечащему врачу стали, в настоящее время вполне доступными. Это позволяет медицинским учреждениям оперативно реагировать и оказывать помощь пациентам.

Таким образом, основой для развития «умной медицины» является цифровизация данных, обеспеченность мобильными устройствами, позволяющими осуществлять контроль и передачу медицинских показателей в онлайн режиме, облачные данные, хранящие и перерабатывающие информацию, искусственный интеллект, обеспечивающий информационную поддержку для принятия рациональных решений в области управления медицинскими процессами.

В силу позитивной демографической динамики в г. Тюмени стабильно увеличивается численность детей. В связи с этим в последние годы 
актуализировалась задача обеспечения детей дошкольного возраста местами в детских садах.

Для обеспечения доступности дошкольного образования, в Тюменской области и городе функционирует региональная автоматизированная информационная система «Электронный детский сад», с помощью которой осуществляется персонифицированной учет детей.

Дошкольные учреждения оборудованы устройствами для видеофиксации происходящих вокруг событий.

В Тюменской области сеть общеобразовательных организаций представлена 190 учебными заведениями. Обеспечение доступа к сети Интернет за счет средств областного бюджета и ежегодное увеличение скорости трафика способствует формированию единого информационного пространства и расширению ресурсов использования цифровых технологий и электронного взаимодействия всех субъектов образовательного процесса.

Во всех школах совершенствуется работа по ведению собственных сайтов, развивается система электронного взаимодействия с учащимися и родителями, во всех школах организован доступ родителей к электронным журналам и дневникам.

С 2016 года начал свою работу проект корпоративного взаимодействия «Школа - ВУЗ - Предприятие», реализация которого направлена на раннюю профориентацию школьников города и области и закрепление специалистов в региональном секторе экономики.

Программы научно-технической направленности реализуются также на базе учреждений дополнительного образования и региональных развивающих центров (Центр прототипирования (fab-lab), школа конструктора, IT-парк, Школа инженерного резерва, Центр робототехники, SolidWorks, 3D-моделирование, Центр личностного и предпрофессионального развития молодежи, Центры молодёжного инновационного творчества). 
В Тюменской области функционирует единая система цифровой библиотеки, создаются проекты общеобразовательной направленности с внедрением игровых технологий. Таким образом, в школах г. Тюмени и Тюменской области создается крепкий фундамент для позитивного внедрения «умных» технологий, где новые поколения получают возможность использовать и совершенствовать полученные в школе компетенции.

Вузы области широко используют информационные технологии, внедряя новые форматы обучения совместно с индустриальными партнерами, среди которых крупнейшие российские компании: ПАО «НК Роснефть», ПАО «Газпром», ПАО «ЛУКОЙЛ», ПАО «СИБУР», «Группа ГМС», ПАО «Сургутнефтегаз», ПАО «Транснефть».

Высшие учреждения Тюмени принимают активное участие в инновационной деятельности города. Тюменский индустриальный университет (ТИУ), опорный вуз Тюменского региона, занимает лидирующие позиции центра науки и инноваций в областной столице. В ТИУ готовят кадры для новой экономики и индустрии 4.0, как по направлениям бакалавриата (например, направление «Инноватика», профиль «Предпринимательство в инновационной деятельности»), так и по программам магистратуры (например, программа «Менеджмент в сфере инноваций»).

В Тюменском государственном университете создан Технопарк, представляющий собой научно-инновационное подразделение, которое специализируется на проектах в области экологии и рационального природопользования, a также технологиях промышленности для нужд нефтегазового комплекса.

В городе Тюмени создана благоприятная среда для вовлечения школьников в техническое творчество и инновационную деятельность, в том числе и на базе университетов. 
Так, с 2016 года в Тюменском индустриальном университете работает Школа инженерного резерва, обучающая школьников по таким востребованным направлениям, как digital-маркетинг, биохимия, композитные материалы, прототипирование, робототехника Arduino, робототехника LEGO и ряду других.

В Тюменском государственном университете функционирует Центр молодежного инновационного творчества «ФабЛаб», позволяющий осуществлять совместную деятельность школьникам и молодым ученым над техническими проектами с использованием современного оборудования с числовым программным управлением.

В вузах широко представлено и дистанционное образование, что позволило оперативно перестроить обучение в условиях коронавирусной пандемии.

В регионе, для удобства граждан, которые переходят на использование мобильных устройств, разработана Единая мобильная платформа взаимодействия между гражданами, организациями и государственными органами. Создана единая точка доступа к информационным ресурсам органов власти для мобильных устройств [6].

Эффективно функционируют региональные мобильные приложения: «Образование 72», «Медицина 72» (до 01.06.2021), «Телемед 72» (с 01.06.2021), «Транспорт 72», «ЖКХ 72», «Виртуальный консультант 72».

Очень важным является то, что информатизация в Тюменской области осуществляется комплексно и системно. Так в целях автоматизации процессов государственного управления и повышения качества принятия управленческих решений в регионе функционируют следующие информационные системы, представленные в таблице 1: 
Таблица 1

ИКТ, действующие в Тюменской области

\begin{tabular}{|c|c|c|c|}
\hline № & $\begin{array}{c}\text { Полное наименование } \\
\text { ИС }\end{array}$ & Оператор & Назначение \\
\hline 1. & $\begin{array}{l}\text { Автоматизированная } \\
\text { информационная система } \\
\text { ведения федерального } \\
\text { регистра муниципальных } \\
\text { нормативных правовых } \\
\text { актов }\end{array}$ & $\begin{array}{l}\text { Аппарат Губернатора } \\
\text { Тюменской области }\end{array}$ & $\begin{array}{l}\text { Обеспечение верховенства } \\
\text { Конституции Российской Федерации } \\
\text { и федеральных законов, учета и } \\
\text { систематизации муниципальных } \\
\text { нормативных правовых актов, } \\
\text { реализации конституционного права } \\
\text { граждан на получение достоверной } \\
\text { информации и создания условий для } \\
\text { получения информации о } \\
\text { муниципальных нормативных } \\
\text { правовых актах органами } \\
\text { государственной власти, органами } \\
\text { местного самоуправления, } \\
\text { должностными лицами и } \\
\text { организациями }\end{array}$ \\
\hline 2. & $\begin{array}{l}\text { Информационная система } \\
\text { обеспечения } \\
\text { градостроительной } \\
\text { деятельности Тюменской } \\
\text { области }\end{array}$ & $\begin{array}{l}\text { Главное управление } \\
\text { строительства } \\
\text { Тюменской области }\end{array}$ & $\begin{array}{l}\text { Обеспечение деятельности органов } \\
\text { исполнительной власти и органов } \\
\text { местного самоуправления в сфере } \\
\text { градостроительства Тюменской } \\
\text { области автоматизированными } \\
\text { инструментами эффективной } \\
\text { реализации ими своих полномочий и } \\
\text { функций в электронном виде, } \\
\text { поддержки принятия управленческих } \\
\text { решений и исполнения требований } \\
\text { законодательства Российской } \\
\text { Федерации в области } \\
\text { градостроительной деятельности }\end{array}$ \\
\hline 3. & $\begin{array}{l}\text { Информационная система } \\
\text { по учету предоставляемой } \\
\text { государственной } \\
\text { поддержки на улучшение } \\
\text { жилищных условий, в том } \\
\text { числе базы данных } \\
\text { молодых семей }\end{array}$ & $\begin{array}{l}\text { Главное управление } \\
\text { строительства } \\
\text { Тюменской области }\end{array}$ & $\begin{array}{l}\text { Исполнение государственных } \\
\text { обязательств по обеспечению } \\
\text { жильем отдельных категорий } \\
\text { граждан, утверждение списков } \\
\text { претендентов на получение субсидий } \\
\text { на строительство и (или) } \\
\text { приобретение жилья в соответствии с } \\
\text { нормативными правовыми актами } \\
\text { Тюменской области }\end{array}$ \\
\hline 4. & $\begin{array}{l}\text { Корпоративная } \\
\text { информационная система } \\
\text { КИС «iSZN» }\end{array}$ & $\begin{array}{l}\text { Департамент } \\
\text { агропромышленного } \\
\text { комплекса } \\
\text { Тюменской области }\end{array}$ & $\begin{array}{l}\text { Контроль и учет денежных средств, } \\
\text { выделяемых на приобретение } \\
\text { (строительство) жилья в } \\
\text { соответствии с федеральной целевой } \\
\text { программой «Устойчивое развитие } \\
\text { сельских территорий на } 2014-2017 \\
\text { годы и на период до } 2020 \text { года» }\end{array}$ \\
\hline
\end{tabular}


Продолжение Таблицы 1

\begin{tabular}{|c|c|c|c|}
\hline 5. & АИС «Мониторинг АПК» & $\begin{array}{l}\text { Департамент } \\
\text { агропромышленного } \\
\text { комплекса } \\
\text { Тюменской области }\end{array}$ & $\begin{array}{l}\text { Автоматизация деятельности } \\
\text { Департамента агропромышленного } \\
\text { комплекса ТО в разрезе МО }\end{array}$ \\
\hline 6. & $\begin{array}{l}\text { Автоматизированная } \\
\text { информационная система } \\
\text { «Мониторинг жилищного } \\
\text { фонда Тюменской } \\
\text { области» }\end{array}$ & $\begin{array}{l}\text { Департамент } \\
\text { жилищно- } \\
\text { коммунального } \\
\text { хозяйства Тюменской } \\
\text { области }\end{array}$ & $\begin{array}{l}\text { Формирование единой базы данных } \\
\text { объектов жилищного фонда - жилых } \\
\text { домов, единой базы данных } \\
\text { сведений, собранных в результате } \\
\text { раскрытия информации о } \\
\text { деятельности управляющих } \\
\text { организаций в рамках } 731 \\
\text { Постановления Правительства РФ от } \\
23.09 .2010,3) \text { А Аакже автоматизация } \\
\text { сбора и анализа форм статистической } \\
\text { отчётности }\end{array}$ \\
\hline 7. & $\begin{array}{l}\text { Региональная } \\
\text { государственная } \\
\text { информационная система } \\
\text { жилищно-коммунального } \\
\text { хозяйства Тюменской } \\
\text { области (РГИС ЖКХ ТО) }\end{array}$ & $\begin{array}{l}\text { Департамент } \\
\text { жилищно- } \\
\text { коммунального } \\
\text { хозяйства Тюменской } \\
\text { области }\end{array}$ & $\begin{array}{l}\text { Сбор, хранение и обработка } \\
\text { информации, размещаемой в } \\
\text { Системе РГИС ЖКХ ТО, } \\
\text { обеспечение доступа к информации, } \\
\text { размещенной в Системе, } \\
\text { предоставление такой информации в } \\
\text { электронной форме, ведение } \\
\text { информации об управляющих } \\
\text { организациях, договорах управления } \\
\text { и перечне МКД в управлении, } \\
\text { выгрузка информации в ГИС ЖКХ, } \\
\text { выгрузка аналитической информации } \\
\text { в информационно-аналитическую } \\
\text { систему Тюменской области }\end{array}$ \\
\hline 8. & $\begin{array}{l}\text { АИС «Реестр } \\
\text { инвестиционных } \\
\text { проектов» }\end{array}$ & \begin{tabular}{|l} 
Департамент \\
инвестиционной \\
политики и \\
государственной \\
поддержки \\
предпринимательства \\
Тюменской области \\
\end{tabular} & $\begin{array}{l}\text { Сбор данных об инвестиционных, } \\
\text { инновационных проектах, } \\
\text { инфраструктурных площадках, } \\
\text { потенциальных инвесторах области }\end{array}$ \\
\hline 9. & $\begin{array}{l}\text { Единая информационная } \\
\text { система Департамента } \\
\text { инвестиционной политики } \\
\text { и государственной } \\
\text { поддержки } \\
\text { предпринимательства } \\
\text { Тюменской области }\end{array}$ & $\begin{array}{l}\text { Департамент } \\
\text { инвестиционной } \\
\text { политики и } \\
\text { государственной } \\
\text { поддержки } \\
\text { предпринимательства } \\
\text { Тюменской области }\end{array}$ & $\begin{array}{l}\text { Комплексное информационное } \\
\text { обслуживание промышленных } \\
\text { предприятий, субъектов } \\
\text { предпринимательской и } \\
\text { инвестиционной деятельности по } \\
\text { вопросам, входящим в компетенцию } \\
\text { Департамента, на основе } \\
\text { современных информационных } \\
\text { технологий }\end{array}$ \\
\hline
\end{tabular}


Продолжение Таблицы 1

\begin{tabular}{|c|c|c|c|}
\hline & $\begin{array}{l}\text { АИС «Учет начислений и } \\
\text { платежей» }\end{array}$ & $\begin{array}{l}\text { Департамент } \\
\text { информатизации } \\
\text { Тюменской области }\end{array}$ & $\begin{array}{l}\text { Информационное обеспечение } \\
\text { деятельности регионального } \\
\text { агрегатора начислений. Обеспечение } \\
\text { взаимодействия Участников ГИС } \\
\text { ГМП Тюменской области с ГИС } \\
\text { ГМП через региональный агрегатор } \\
\text { начислений. }\end{array}$ \\
\hline 11. & $\begin{array}{l}\text { Региональный сегмент } \\
\text { Единой государственной } \\
\text { информационной системы } \\
\text { в сфере здравоохранения } \\
\text { (РС ЕГИСЗ) }\end{array}$ & \begin{tabular}{|l} 
Департамент \\
информатизации \\
Тюменской области
\end{tabular} & $\begin{array}{l}\text { Информационная поддержка } \\
\text { методического и организационного } \\
\text { обеспечения деятельности } \\
\text { участников системы } \\
\text { здравоохранения в Тюменской } \\
\text { области, фунцционирующей как } \\
\text { часть единой государственной } \\
\text { информационной системы }\end{array}$ \\
\hline 12. & $\begin{array}{l}\text { Система фото- } \\
\text { видеофиксации (ЦАФАП) }\end{array}$ & \begin{tabular}{|l|} 
Департамент \\
информатизации \\
Тюменской области \\
\end{tabular} & $\begin{array}{l}\text { Автоматизированная фиксация } \\
\text { административных правонарушений } \\
\text { в области дорожного движения }\end{array}$ \\
\hline 13. & АИС СМЭВ ТО & \begin{tabular}{|l} 
Департамент \\
информатизации \\
Тюменской области
\end{tabular} & $\begin{array}{l}\text { Обеспечение защищенного } \\
\text { взаимодействия граждан, } \\
\text { государственных служащих и } \\
\text { информационных систем всех } \\
\text { уровней (региональных и } \\
\text { муниципальных органов власти, } \\
\text { территориальных подразделений } \\
\text { федеральных органов власти, } \\
\text { организаций и учреждений, } \\
\text { расположенных на территории } \\
\text { Тюменской области), в том числе } \\
\text { обеспечение доступа граждан к } \\
\text { государственным и муниципальным } \\
\text { услугам, предоставляемым в } \\
\text { электронном виде }\end{array}$ \\
\hline 14. & $\begin{array}{l}\text { Геоинформационная } \\
\text { система Тюменской } \\
\text { области }\end{array}$ & $\begin{array}{l}\text { Департамент } \\
\text { информатизации } \\
\text { Тюменской области }\end{array}$ & $\begin{array}{l}\text { Предоставление пользователям } \\
\text { достоверных, оперативных и } \\
\text { актуальных пространственных } \\
\text { данных Тюменской области }\end{array}$ \\
\hline 15. & $\begin{array}{l}\text { Система электронного } \\
\text { документооборота и } \\
\text { делопроизводства }\end{array}$ & \begin{tabular}{|l} 
Департамент \\
информатизации \\
Тюменской области
\end{tabular} & $\begin{array}{l}\text { Обеспечение органов } \\
\text { государственной власти Тюменской } \\
\text { области, подведомственных } \\
\text { учреждений ТО и ОМСУ ТО } \\
\text { электронным документооборотом }\end{array}$ \\
\hline
\end{tabular}


Продолжение Таблицы 1

\begin{tabular}{|c|c|c|c|}
\hline & $\begin{array}{l}\text { AИС «Cascade Model } \\
\text { Builder» }\end{array}$ & $\begin{array}{l}\text { Департамент } \\
\text { информатизации } \\
\text { Тюменской области }\end{array}$ & $\begin{array}{l}\text { Получение актуальной информации } \\
\text { о технологии выполнения рабочих } \\
\text { процессов, связанных с } \\
\text { непосредственной профессиональной } \\
\text { деятельностью сотрудников } \\
\text { учреждений органов } \\
\text { государственной власти, } \\
\text { подведомственных им учреждений } \\
\end{array}$ \\
\hline & $\begin{array}{l}\text { ИС «Единый центр } \\
\text { хранения данных системы } \\
\text { видеонаблюдения } \\
\text { Тюменской области» }\end{array}$ & $\begin{array}{l}\text { Департамент } \\
\text { информатизации } \\
\text { Тюменской области }\end{array}$ & $\begin{array}{l}\text { Прием видеопотоков. Запись, } \\
\text { хранение ретрансляция } \\
\text { видеоматериалов. Выгрузка архива } \\
\text { видеоматериала }\end{array}$ \\
\hline 18. & $\begin{array}{l}\text { ИС «Система управления } \\
\text { силами и средствами» }\end{array}$ & $\begin{array}{l}\text { Департамент } \\
\text { информатизации } \\
\text { Тюменской области }\end{array}$ & $\begin{array}{l}\text { Автоматизация процессов } \\
\text { подготовки и планирования службы, } \\
\text { отчётности, управления нарядами } \\
\text { подразделений МВД, } \\
\text { задействованных в обеспечении } \\
\text { общественного порядка и } \\
\text { безопасности, работающих в системе } \\
\text { единой дислокации }\end{array}$ \\
\hline 19. & АИС «ЭОС 112» (Протей) & $\begin{array}{l}\text { Департамент } \\
\text { информатизации } \\
\text { Тюменской области }\end{array}$ & $\begin{array}{l}\text { Прием и обработка вызовов к } \\
\text { экстренным службам по единому } \\
\text { номеру, контроль реагирования на } \\
\text { обращения, межведомственная } \\
\text { координация, а также } \\
\text { информационная поддержка } \\
\text { административных органов }\end{array}$ \\
\hline 20. & АИС «СЭО» & $\begin{array}{l}\text { Департамент } \\
\text { информатизации } \\
\text { Тюменской области }\end{array}$ & $\begin{array}{l}\text { Организация учебного процесса с } \\
\text { применением электронного } \\
\text { обучения, дистанционных } \\
\text { образовательных технологий }\end{array}$ \\
\hline 21. & . $\begin{array}{l}\text { АИС «Электронный } \\
\text { колледж ТО» }\end{array}$ & $\begin{array}{l}\text { Департамент } \\
\text { образования и науки } \\
\text { Тюменской области }\end{array}$ & $\begin{array}{l}\text { Автоматизация оказания } \\
\text { государственных и муниципальных } \\
\text { услуг в сфере среднего специального } \\
\text { образования }\end{array}$ \\
\hline 22. & $\mid \begin{array}{l}\text { Информационная система } \\
\text { управления образованием }\end{array}$ & $\begin{array}{l}\text { Департамент } \\
\text { образования и науки } \\
\text { Тюменской области } \\
\end{array}$ & $\begin{array}{l}\text { Автоматизация информационно- } \\
\text { аналитической деятельности органов } \\
\text { управления образованием }\end{array}$ \\
\hline 23. & . $\begin{array}{l}\text { ИС «Единая дежурно- } \\
\text { диспетчерская служба» }\end{array}$ & $\begin{array}{l}\text { Департамент } \\
\text { информатизации } \\
\text { Тюменской области }\end{array}$ & $\begin{array}{l}\text { Комплексная информатизация } \\
\text { процессов функционирования ЕДДС } \\
\text { во взаимодействии с местными и } \\
\text { региональными ДДС и Системой-112 }\end{array}$ \\
\hline
\end{tabular}


Продолжение Таблицы 1

\begin{tabular}{|c|c|c|c|}
\hline 24. & $\begin{array}{l}\text { АВЕРС: Управление } \\
\text { лесным фондом. ПРОФ }\end{array}$ & $\begin{array}{l}\text { Департамент лесного } \\
\text { комплекса } \\
\text { Тюменской области }\end{array}$ & $\begin{array}{l}\text { Ведение реестра лесопользователей, } \\
\text { формирования договоров аренды } \\
\text { лесных участков, } \\
\text { администрирования платежей } \\
\text { лесопользователей, коммутирования } \\
\text { информации с единой } \\
\text { государственной } \\
\text { автоматизированной } \\
\text { информационной системой учета } \\
\text { древесины и сделок с ней (ЕГАИС), } \\
\text { ГИС ГМП по учету платежей } \\
\text { бюджетной системы РФ }\end{array}$ \\
\hline & $\begin{array}{l}\text { Информационная система } \\
\text { персональных данных } \\
\text { «Бухгалтерский и } \\
\text { кадровый учет» }\end{array}$ & \begin{tabular}{|l|} 
Департамент \\
физической культуры, \\
спорта и \\
дополнительного \\
образования \\
Тюменской области \\
\end{tabular} & $\begin{array}{l}\text { Ведение кадрового и бухгалтерского } \\
\text { учета в Департаменте физической } \\
\text { культуры, спорта и дополнительного } \\
\text { образования Тюменской области. }\end{array}$ \\
\hline & $\begin{array}{l}\text { Информационная система } \\
\text { социальной защиты } \\
\text { населения Тюменской } \\
\text { области }\end{array}$ & \begin{tabular}{|l|} 
Департамент \\
социального развития \\
Тюменской области
\end{tabular} & $\begin{array}{l}\text { Информационное обеспечение } \\
\text { деятельности Департамента } \\
\text { социального развития Тюменской } \\
\text { области по реализации единой } \\
\text { государственной политики, } \\
\text { осуществлению управления в сферах } \\
\text { социальной поддержки и } \\
\text { социального обслуживания } \\
\text { населения в Тюменской области }\end{array}$ \\
\hline 27. & $\begin{array}{l}\text { Автоматизированная } \\
\text { информационная система } \\
\text { органа опеки, } \\
\text { попечительства и охраны } \\
\text { прав детства Тюменской } \\
\text { области }\end{array}$ & \begin{tabular}{|l|} 
Департамент \\
социального развития \\
Тюменской области
\end{tabular} & $\begin{array}{l}\text { Система обеспечивает учет детей- } \\
\text { сирот, детей, оставшихся без } \\
\text { попечения родителей, } \\
\text { совершеннолетних недееспособных } \\
\text { или не полностью дееспособных } \\
\text { граждан, учет опекунов, } \\
\text { попечителей, приемных родителей, } \\
\text { граждан, желающих принять ребенка } \\
\text { на воспитание в свою семью }\end{array}$ \\
\hline 28. & $\mid$\begin{tabular}{|l} 
Региональный сегмент \\
единой информационно- \\
аналитической системы \\
автоматизации функций \\
тарифного регулирования в \\
Тюменской области
\end{tabular} & \begin{tabular}{|l} 
Департамент \\
тарифной и ценовой \\
политики Тюменской \\
области
\end{tabular} & $\begin{array}{l}\text { Система автоматизирует } \\
\text { формирование балансов } \\
\text { теплоснабжения, водоснабжения и } \\
\text { водоотведения, мониторинг факта } \\
\text { раскрытия и сбор показателей, } \\
\text { подлежащих раскрытию, в сфере } \\
\text { коммунальных услуг, публикация } \\
\text { раскрываемой информации } \\
\text { организациями, осуществляющими } \\
\text { регулируемые виды деятельности }\end{array}$ \\
\hline
\end{tabular}


Продолжение Таблицы 1

\begin{tabular}{|c|c|c|c|}
\hline & $\begin{array}{l}\text { Система проведения } \\
\text { опросов }\end{array}$ & $\begin{array}{l}\text { Департамент труда и } \\
\text { занятости населения } \\
\text { Тюменской области }\end{array}$ & $\begin{array}{l}\text { Осуществление консолидации } \\
\text { данных, полученных в процессе } \\
\text { проведения интерактивных опросов с } \\
\text { использованием устройств для } \\
\text { проведения опросов и формирование } \\
\text { отчетов на основе этих данных }\end{array}$ \\
\hline & $\begin{array}{l}\text { Информационная система } \\
\text { консолидации отчетности }\end{array}$ & $\begin{array}{l}\text { Департамент труда и } \\
\text { занятости населения } \\
\text { Тюменской области }\end{array}$ & $\begin{array}{l}\text { Сбор, проверка и консолидация } \\
\text { данных, формируемых в системах } \\
\text { регистрационного учета } \\
\text { подведомственных государственных } \\
\text { автономных учреждениях } \\
\text { Тюменской области Центрах } \\
\text { занятости населения при } \\
\text { формировании и ведении регистров } \\
\text { получателей услуг в сфере занятости } \\
\text { населения (физических лиц и } \\
\text { работодателей), и последующую } \\
\text { передачу и загрузку сводных } \\
\text { отчетных форм в «Информационную } \\
\text { систему консолидации отчетности» } \\
\text { Федеральной службы по труду и } \\
\text { занятости }\end{array}$ \\
\hline & $\begin{array}{l}\text { ИС «Переселение } \\
\text { соотечественников в } \\
\text { Тюменскую область» }\end{array}$ & $\begin{array}{l}\text { Департамент труда и } \\
\text { занятости населения } \\
\text { Тюменской области }\end{array}$ & $\begin{array}{l}\text { Автоматизация ведения регистра } \\
\text { граждан, участвующих в ГП } \\
\text { «Оказание содействия } \\
\text { добровольному переселению в } \\
\text { Тюменскую область } \\
\text { соотечественников, проживающих за } \\
\text { рубежом, на 2013-2020 годы» }\end{array}$ \\
\hline 32. & $\begin{array}{l}\text { Автоматизированная } \\
\text { информационная система } \\
\text { «СКИФ - бюджетный } \\
\text { процесс» }\end{array}$ & $\begin{array}{l}\text { Департамент } \\
\text { финансов Тюменской } \\
\text { области }\end{array}$ & $\begin{array}{l}\text { Автоматизация приема, обработки и } \\
\text { хранения отчетности, контроля за } \\
\text { полнотой и правильностью } \\
\text { составления отчетности, } \\
\text { формирования необходимых } \\
\text { сводных документов, на базе } \\
\text { выбранных из отчетных данных } \\
\text { показателей, подготовки различных } \\
\text { аналитических форм }\end{array}$ \\
\hline
\end{tabular}


Продолжение Таблицы 1

\begin{tabular}{|c|c|c|c|}
\hline & $\begin{array}{l}\text { Автоматизированная } \\
\text { информационная система } \\
\text { записи актов гражданского } \\
\text { состояния Тюменской } \\
\text { области }\end{array}$ & $\begin{array}{l}\text { Управление записи } \\
\text { актов гражданского } \\
\text { состояния Тюменской } \\
\text { области }\end{array}$ & $\begin{array}{l}\text { Автоматизация деятельности органов } \\
\text { ЗАГС Тюменской области по } \\
\text { регистрации и учету записей актов } \\
\text { гражданского состояния, а также } \\
\text { функций предоставления } \\
\text { государственных услуг по } \\
\text { регистрации актов гражданского } \\
\text { состояния в электронной форме и } \\
\text { функций электронного } \\
\text { взаимодействия между органами } \\
\text { ЗАГС и иными органами } \\
\text { государственной власти в рамках } \\
\text { реализации предоставления органами } \\
\text { государственной власти услуг } \\
\text { (функций) в электронной форме }\end{array}$ \\
\hline 34. & $\begin{array}{l}\text { АИС «Оборот алкогольной } \\
\text { продукции Тюменской } \\
\text { области» }\end{array}$ & $\begin{array}{l}\text { Департамент } \\
\text { потребительского } \\
\text { рынка и туризма } \\
\text { Тюменской области }\end{array}$ & $\begin{array}{l}\text { Сбор информации о выявленных } \\
\text { правонарушениях в области продажи } \\
\text { алкогольной продукции тюменскими } \\
\text { производителями }\end{array}$ \\
\hline & $\begin{array}{l}\text { АИС «Электронный архив } \\
\text { Тюменской области» }\end{array}$ & $\begin{array}{l}\text { Управление по делам } \\
\text { архивов Тюменской } \\
\text { области }\end{array}$ & $\begin{array}{l}\text { Многопользовательская работа с } \\
\text { электронным архивом документов. } \\
\text { Эффективный санкционированный } \\
\text { доступ к архивным документам, как } \\
\text { в локальной сети, так и удаленно } \\
\text { через сеть Интернет }\end{array}$ \\
\hline
\end{tabular}

Все это убедительно показывает, что Тюменская область обоснованно входит в число регионов-лидеров по уровню развития информатизации. Рассматривая положение дел с позиции горожан, следует отметить, что современный человек видит город как набор сервисов, подразумевающих такие преимущества как повсеместная обеспеченность связью, оптимальность перемещения в городе, оперативность информационной поддержки, в том числе запись к врачу, запись ребенка в школу, детский сад, удаленные покупки, оплата услуг ЖКХ, информирование о происшествиях. Ориентация на человека является основным принципом умного города. На обеспечение такого подхода ориентированы нормативные документы, введенные в действие Минстроем РФ, являющимся координатором программы «Умный город» в Российской Федерации. 


\section{СТРАТЕГИЯ НАУЧНО-ТЕХНОЛОГИЧЕСКОГО РАЗВИТИЯ РОССИИ: ПРОБЛЕМЫ И ПЕРСПЕКТИВЫ РЕАЛИЗАЦИИ}

Так, в частности, методические рекомендации по цифровизации городского хозяйства, утвержденные приказом Минстроя № 23/пр. от 24.04.2019, предусматривают создание в городах цифровой платформы вовлечения граждан в решение вопросов городского развития «Активный горожанин», обеспечивающей возможность участия жителей в решении городских проблем. Они ориентируют на создание сервисов:

— по участию в рейтинговом голосовании по реализации мероприятий в сфере городского хозяйства;

— обеспечения дистанционного обращения граждан, в том числе путем телефонного сообщения, с заявлением и контролем своевременного реагирования на них;

— дистанционного обращения граждан с частной инициативой в сфере городского хозяйства, городского управления и развития, соблюдения регламента рассмотрения частных инициатив;

— публичного размещения планов городских властей по градостроительным вопросам, приоритетам благоустройства, важным городским проектам и иным вопросам, затрагивающим интересы горожан с обеспечением возможности внесения гражданами замечаний и предложений [7].

Признанным лидером в России в реализации проекта «Умный город» является Москва, где с 2014 года эффективно развивается портал «Активный гражданин», на котором на регулярной основе проводятся опросы горожан [8].

Аналогичные порталы имеются в Тюменской области и в г. Тюмени, для привлечения большего внимания к данным сервисам запущены мобильные приложения, доступные для скачивания в AppStore и Google Play, но относительный уровень социальной активности горожан, по сравнению с г. Москвой существенно ниже. 
Авторами с 2018 г., в рамках Стратегического проекта «Создание регионального инновационного кластера в сфере компетенций SMART-City IoT/Iiot и Big Data» ФГБОУ ВО «Тюменский индустриальный университет» проводится социологический мониторинг, позволяющий оценивать мнения населения г. Тюмени, по проблемным вопросам внедрения элементов программы «Умный город» и стратегии развития Тюмени по этому пути.

Результаты оценок 2018 г. и 2020 г. показывают положительную динамику роста числа «умных» жителей, способных не только понять необходимость внедрения в городское пространство технологий и элементов «умного» города, но и потенциально готовых принимать активное участие в этих преобразованиях $[3,9]$.

За 2 года более чем на 9\% (с 24,3 до 33,6\%) увеличилось число жителей, считающих, что жизнь в городе после реализации программы «Умный город» станет более комфортной и интересной; повысилось и количество респондентов, считающих, что программа будет способствовать созданию новых рабочих мест, что особенно актуально в условиях ограничений, связанных с пандемией коронавируса (табл. 2).

Таблица 2

\section{Отношение жителей к вопросам перспективы развития программы} «Умный город» в г. Тюмени (в \% к числу опрошенных)

\begin{tabular}{|l|c|c|c|}
\hline \multicolumn{1}{|c|}{ Показатель оценки } & $\begin{array}{c}2020 \\
\text { год }\end{array}$ & $\begin{array}{c}2018 \\
\text { год }\end{array}$ & Тенденции (+/-) \\
\hline Жизнь в городе станет комфортней и интересней & 33,6 & 24,3 & $+9,3$ \\
\hline $\begin{array}{l}\text { Программа позволит понять перспективы } \\
\text { развития города }\end{array}$ & 35,1 & 33,8 & $+1,3$ \\
\hline $\begin{array}{l}\text { Программа позволит найти новые возможности } \\
\text { для заработка }\end{array}$ & 10,4 & 6,6 & $+3,8$ \\
\hline Не думаю, что лично мне это будет полезно & 8,3 & 6,6 & $+1,7$ \\
\hline Не могу оценить, так как далек от всего этого & 14,5 & 11,8 & $+2,7$ \\
\hline
\end{tabular}


В то же время наблюдается увеличение числа жителей Тюмени, выразивших пессимистическое настроение по отношению к данной программе, заявивших, что не думают в этом направлении, а 8,3 \% считают эту программу бесполезной или не первостепенной с точки зрения их личных интересов.

Можно предположить, что причиной такого развития социального пессимизма является продолжающееся негативное воздействие эпидемии коронавируса, вызвавшее масштабные проблемы в экономике и социальной жизни, ограничивающие взаимодействие и контакты между субъектами.

Косвенным показателем влияния пандемийного фактора на приоритеты и интересы горожан является и изменения в рейтинге использования горожанами мобильных приложений (табл. 3) [9].

Таблица 3

Эволюция рейтинга мобильных приложений в Тюменской области

\begin{tabular}{|c|c|c|c|c|c|c|}
\hline Место & $\begin{array}{c}\text { Рейтинг } \\
\text { цифровых } \\
\text { приложений в } \\
\text { Тюменской } \\
\text { области } \\
\text { в } 2013 \text { г. }\end{array}$ & $\begin{array}{c}\text { Рейтинг } \\
\text { цифровых } \\
\text { приложений в } \\
\text { Тюменской } \\
\text { области } \\
\text { на начало } \\
2014 \text { г. }\end{array}$ & $\begin{array}{c}\text { Рейтинг } \\
\text { цифровых } \\
\text { приложений } \\
\text { в Тюменской } \\
\text { области } \\
\text { в } 2016 \text { г. }\end{array}$ & $\begin{array}{c}\text { Рейтинг } \\
\text { цифровых } \\
\text { приложений } \\
\text { в Тюменской } \\
\text { области } \\
\text { на начало } \\
2019 \text { г. }\end{array}$ & $\begin{array}{c}\text { Рейтинг } \\
\text { цифровых } \\
\text { приложений в } \\
\text { Тюменской } \\
\text { области } \\
\text { на конец } 2019 \text { г., } \\
\text { составленный } \\
\text { администрацией } \\
\text { г. Тюмени }\end{array}$ & $\begin{array}{c}\text { Рейтинг } \\
\text { цифровых } \\
\text { приложений в } \\
\text { Тюменской } \\
\text { области } \\
\text { в } 2020 \text { г. }\end{array}$ \\
\hline 1 & $\begin{array}{l}\text { Приложение } \\
\text { «Тюменьгор- } \\
\text { транса» }\end{array}$ & $\begin{array}{l}\text { Тюмень. } \\
\text { Транспорт }\end{array}$ & Моя Тюмень & Медицина 72 & $\begin{array}{l}\text { Тюмень - наш } \\
\text { дом }\end{array}$ & Медицина 72 \\
\hline 2 & $\begin{array}{l}\text { Афиша } \\
\text { Тюмени }\end{array}$ & Медицина 72 & $\begin{array}{l}\text { Парковки } \\
\text { Тюме- } \\
\text { ни }\end{array}$ & Бизнес 72 & Медицина 72 & ЖКХ 72 \\
\hline 3 & $\begin{array}{l}\text { Недвижимость } \\
\text { Тюмени, } \\
\text { Объявления } \\
\text { Тюмени }\end{array}$ & $\begin{array}{l}\text { Транспортная } \\
\text { карта Тюмени }\end{array}$ & Медицина 72 & Образование 72 & $\begin{array}{l}\text { Парковки } \\
\text { Тюмень }\end{array}$ & ЗАГС 72 \\
\hline
\end{tabular}


Продолжение Таблицы 3

\begin{tabular}{|c|c|c|c|c|c|c|}
\hline 4 & $\begin{array}{l}\text { Транспортная } \\
\text { карта }\end{array}$ & $\begin{array}{l}\text { Мобильный } \\
\text { МФЦ }\end{array}$ & $\begin{array}{l}\text { Тюмень. } \\
\text { Транспорт }\end{array}$ & Транспорт 72 & Я решаю & Запись 72 \\
\hline 5 & Новая Тюмень & $\begin{array}{l}\text { Lafaet } \\
\text { (интернет- } \\
\text { магазин мишек } \\
\text { и цветов) }\end{array}$ & Образование 72 & ЖКХ 72 & $\begin{array}{l}\text { Электронная } \\
\text { школа }\end{array}$ & Образование 72 \\
\hline 6 & Мегаеда & $\begin{array}{l}\text { Выписка } \\
\text { Егрюл Тюмень }\end{array}$ & - & Пойдем в музей & $\begin{array}{l}\text { Тюмень. } \\
\text { Транспорт }\end{array}$ & $\begin{array}{l}\text { Виртуальный } \\
\text { консультант } 72\end{array}$ \\
\hline 7 & $\begin{array}{l}\text { Тюменский } \\
\text { бизнес-журнал }\end{array}$ & $\begin{array}{l}\text { Этажи } \\
\text { Недвижимость } \\
\text { и Квартиры }\end{array}$ & - & ЗАГС 72 & - & Транспорт 72 \\
\hline 8 & Арсенал плюс & Арсенал+ & - & - & - & Форум 72 \\
\hline 9 & $\begin{array}{l}\text { Маркетинг- } \\
\text { Консультант }\end{array}$ & Такси Олимп & - & - & - & - \\
\hline 10 & Красная карта & $\begin{array}{l}\text { Максим: } \\
\text { заказ такси }\end{array}$ & - & - & - & - \\
\hline $\begin{array}{c}\text { Источ- } \\
\text { ник }\end{array}$ & БEZ-формата & Вслух.ру & Выбирай & $\begin{array}{l}\text { Комсомольская } \\
\text { правда }\end{array}$ & Тюменская линия & Вслух.ру \\
\hline
\end{tabular}

Рассматривая в комплексе условия, способствующие развитию города, как «умного», нужно отметить, что в Тюмени реализуется политика, направленная на поддержку инновационной деятельности за счет создания экономических, правовых, организационных условий для технологических предпринимателей. В рамках созданного «Западно-Сибирского инновационного центра» осуществляет деятельность Бизнес-инкубатор, оказывающий государственную поддержку субъектам малого и среднего предпринимательства в сфере научной, научно-технической и инновационной деятельности.

В Тюменской области выстроена система преференций для региональных IT-компаний: льготное налогообложение, субсидии на создание и испытание опытных образцов, на научно-исследовательские работы, на закупку оборудования; осуществляется финансовая поддержка в форме - 
«инновационные займы»; созданы условия для аренды помещений в Тюменском технопарке и в IT-инкубаторе - 1 руб. за квадратный метр площади.

В Тюменской области в рамках регионального проекта «Цифровые технологии» для ИТ-компаний создан специальный электронный сервис «ИТ-навигатор». Здесь организации, заинтересованные в получении поддержки своего ИТ-бизнеса либо трансформации деятельности за счет цифровых технологий, могут узнать о действующих льготах, грантах и преференциях от государства. Цель сервиса - донести информацию до предпринимателей и помочь выбрать меры поддержки с учетом индивидуальных особенностей и задач.

С 2010 года работа по повышению компьютерной грамотности граждан ведется централизованно в рамках программы по повышению компьютерной грамотности населения области «Расширяя горизонты».

С 2017 года в г. Тюмени реализуется проект «Школа программирования». С 2018 года - дополнительно в двух городах области - Тобольске и Ишиме. А с 2020 года все курсы проводятся в дистанционном формате. Курсы ускоренной подготовки специалистов под потребности ИТ-компаний. Курсы бесплатны как для слушателей, так и для «заказчиков». Программы составляются c учетом потребностей заинтересованных ИТ-компаний. Преподавателями выступают либо сотрудники «заказчика», либо специалисты, которых одобрил «заказчик».

Перечень осваиваемых технологий и языков программирования широк: JavaScript, PHP, Java, 1C, Python, C\# и др. с изучением разных фреймворков и сред разработки.

Важнейшее условие решения задачи формирования сектора нейротехнологий в региональной экономике - опережающая подготовка молодых специалистов. Для этого в области действует проект «Кадры для 
цифровой экономики», одна из задач которого - выявление талантливых и заинтересованных школьников в профильных областях знаний и построение фундамента для взращивания кадрового потенциала региона. Школа юных нейроинженеров служит инструментом для выполнения этой задачи.

В городе ежегодно проводятся крупные мероприятия, направленные на развитие IT-технологий, такие как Innoweek, Инфотех, ИБ - без границ, Тюменский нефтегазовый форум.

Таким образом, можно констатировать, что материально-техническая база и интеллектуальные ресурсы для развития г. Тюмени, как умного города позволяют эффективно реализовать данную программу развития территории.

\section{Список литературы}

1. Индикаторы умных городов НИИТС — 2017 // НИИТС [Электронный pecypc]. 2017. URL: http://niitc.ru/publications/SmartCities.pdf - Текст : электронный.

2. Умные города: развитие концепции и практики, положение России на эволюционном пути // Презентация Мокрушиной К. (Центр городских исследований IEMS Сколково) [Электронный ресурс]. Новосибирск, 26 апреля 2017 года. Режим доступа: https://urbc.skolkovo.ru/downloads/documents/ SUrbC/Events_Reports/SKOLKOVO_UrbC_Novosibirsk_2017-04.pdf.

3. Белоножко М.Л. Оценки перспектив развития г. Тюмени в рамках концепции «Smart-City» в представлении жителей города (социологический ракурс) / М.Л. Белоножко, О.М. Барбаков, Б.М. Лихтенштейн, Д.А. Костырева. - Текст : непосредственный // Известия высших учебных заведений. Социология. Экономика. Политика. - 2019. - № 3. - С. 58-73.

4. Минкомсвязь представила рейтинг информатизации регионов-2017. [Электронный ресурc]. URL: http://d-russia.ru/minkomsvyaz-predstavila-rejtinginformatizatsii-regionov-2017.html 
5. Умные города. [Электронный ресурс]. URL:http://smartcity.cnews.ru/ articles/2018-08-15_tsifrovaya_meditsina_zdravoohranenie_v_umnom_gorode/

6. Доступная «цифра»: так ли дорого сделать город «умным» [Электронный ресурc]. URL: http://www.forbes.ru/tehnologii/342231-dostupnayacifra-tak-li-dorogo-sdelat-gorod-umnym.

7. Методические рекомендации по цифровизации городского хозяйств.: утверждены Приказом Минстроя РФ от 24.04.19 №23/пр.]. - URL: https://minstroyrf.gov.ru/upload/iblock/f3d/prikaz-235pr-_1_.pdf. - Текст : электронный.

8. Активный гражданин - проект. Москва : [сайт]. - URL: https://ag.mos.ru/home (дата обращения: 06.12.2020). - Текст : электронный.

9. Лихтенштейн Б.М. Умный город, власть и население: субъектнообъектные взаимодействия) / Б.М. Лихтенштейн, О.Ф. Данилов, Д.А. Костырева. - Текст : непосредственный // Известия высших учебных заведений. Социология. Экономика. Политика. - 2021. - № 2. - С. 49-70.

10. Павлова Л.Л., Барбаков О.М. Качество жизни человека в регионе под влиянием процессов цифровизации: программы реализации, оценка / Л.Л. Павлова, О.М. Барбаков. - Текст : непосредственный // Известия высших учебных заведений. Социология. Экономика. Политика. - 2021. - № 2. C. 86-102. 


\section{РАЗДЕЛ ІІ.}

\section{ОБУЧЕНИЕ, РАЗВИТИЕ, ВОСПИТАНИЕ ЛИЧНОСТИ СЕГОДНЯ}

УДК: 37.036:398 (56)

Глава 4.

ЦЕЛЕСООБРАЗНОСТЬ СМЕНЫ ФУНДАМЕНТАЛЬНЫХ ОСНОВ

ОБУЧЕНИЯ ИНОСТРАННОМУ ЯЗЫКУ СТУДЕНТОВ

НЕЯЗЫКОВЫХ СПЕЦИАЛЬНОСТЕЙ БОЛЕЕ ЭФФЕКТИВНЫМИ

ОБРАЗОВАТЕЛЬНЫМИ СТРАТЕГИЯМИ

Гадзаова Л.П. доктор педагогических наук, профессор, профессор кафедры иностранных языков для неязыковых специальностей ФГБОУ ВО «Северо-Осетинский государственный университет (СОГУ) им. К.Л. Хетагурова»

Чеченский государственный университет

Аннотация: В статье представлены результаты анализа методов современного обучения иностранному языку студентов неязыковых специальностей. Традиционные методы обучения иностранным языкам в сфере высшего образования переориентировались с нагрузки на преподавателя больше на студентов и через сочетание с современными инновационными подходами сосредоточились на активизации форм социального и коммуникативного взаимодействия. Преодолевается, не без труда, но под натиском современных жестких требований к знаниям иностранных языков, пассивность студентов, хотя наблюдается наличие собственного опыта 
студентов в изучении иностранного языка до вуза. Для соответствия завышенному по прежним меркам уровню владения иностранными языками задействовано много аудиовизуальных, цифровых приобретений лингвоязыковой информации (аудио файлы, компьютерные видео, интернет ресурсы, обучающие приложения). Традиционные методы обучения продолжают играть роль в сегодняшнем процессе обучения иностранному языку как теоретическая основа продвинутых методов и подходов. Они систематически дополняются методологической компетентностью, осознанием студентами компетенции непрерывного самостоятельного обучения в сочетании с важными методической и социальной компетентностями, лингво-культурологическими языковыми навыками. Современный процесс обучения рассматривается прагматично, основное внимание рекомендуется уделять моделям различной вербализации речевых намерений.

Ключевые слова: фундаментальные основы обучения иностранному языку в неязыковом вузе, стратегические ресурсы развития иноязычных навыков.

\title{
THE EXPEDIENCY OF CHANGING THE FUNDAMENTAL
} FOUNDATIONS OF TEACHING A FOREIGN LANGUAGE TO STUDENTS OF NON-LINGUISTIC SPECIALTIES WITH MORE EFFECTIVE EDUCATIONAL STRATEGIES

\section{Gadzaova L.P.}

\begin{abstract}
The article presents the results of the analysis of methods of modern foreign language teaching to students of non-linguistic specialties. Traditional methods of teaching foreign languages in the field of higher education have been reoriented from the load on the teacher more on the students and, through a


combination with modern innovative approaches, have focused on activating forms of social and communicative interaction. The passivity of students is overcome, not without difficulty, but under the onslaught of modern strict requirements for knowledge of foreign languages, although there is the presence of students' own experience in learning a foreign language before university. A lot of audiovisual, digital acquisitions of linguistic and linguistic information (Audio files, computer videos, Internet resources, training applications) are involved in order to meet the inflated level of foreign language proficiency by previous standards. Traditional teaching methods continue to play a role in today's foreign language teaching process as a theoretical basis for advanced methods and approaches. They are systematically supplemented by methodological competence, students' awareness of the competence of continuous independent learning in combination with important methodological and social competencies, linguistic and cultural language skills. The modern learning process is considered pragmatically, it is recommended to pay special attention to models of various verbalization of speech intentions.

Key words: fundamental principles of teaching a foreign language in a nonlinguistic university, strategic resources for the development of foreign language skills.

Введение. Цифровые инновационные методы овладения иностранным языком способствуют преимущественно самостоятельной деятельности студентов вуза, реальной языковой практике, к которой они стремятся; для достижения цели обучения. Теоретические знания о грамматических структурах и правилах их применения связываются с передаваемым действием, шаблонами их реализации, ориентированными на дальнейшее совершенствование методической и социальной компетентностей. Методическая компетентность - это способность приобретения новых знаний самостоятельно и выработки стратегии для практического использования 
иностранных языков в различных жизненных и профессиональных ситуациях. Как правило, социальная компетентность - это умение работать в команде, а также получать информацию из социального контекста (газетные статьи, плакаты, статьи в Интернете и т.д.), что само по себе дополняет дидактическое содержание последовательно реализуемой языковой компетентности. Отдельные элементы педагогического сопровождения, как демонстрация в обсуждении, разного рода и сложности упражнения, групповая работа по сравнительно-сопоставительному переводу аутентичных текстов, тренинги в команде в ролевых играх (симуляции, тематическое ситуационное обучение, самостоятельное обучение, проектное обучение и т.д.) дополняют инновационные методы и формы обучения.

Методы и методология. Для реализации предлагаемой концепции обучения иностранному языку необходим широкий спектр методов и инструментов психолого-педагогического подхода в обучении и овладении языковой компетентностью; компететностный и коммуникативный подходы, направленные на формирование эффективных дидактических и коммуникативных навыков, ориентированных на практико-ориентированные компетенции и реализуемые высококвалифицированными и мотивированными преподавателями, обладающими как хорошо выраженными языковыми, так и глубокими методологическими и дидактическими навыками; владеющими межкультурной компетентностью и успешно применяющими разработанные авторские тактику и стратегию преподавания на основе учебных программ, учебных пособий, содержащих материал по актуальным проблемам современности.

Результаты исследования. Цель обучения - развить чувство языка, приближенное к родному. Из-за очень обобщённой методологической информации, успех используемых компетентностного и коммуникативного подходов во многом зависит от определенных факторов, таких, например, как 
личность преподавателя, его увлеченность, умение словесного и невербального объяснения. Язык, ориентированный на повседневные ситуации, представлен, в основном, в диалогах пассивного использования. Грамматические правила закрепляются схематически. Языковое посредничество сопровождается и поддерживается визуально (картинки, слайды, видео). Языковые шаблоны, встроенные в ситуации, включаются в разговорные упражнения с использованием необходимых упражнений; аудиовизуальный / аудиоязыковой метод реализуется на основе аудиовизуальных структурно-обобщающих презентациях.

Преподавательская деятельность требует цифровой грамотности, чтобы целенаправленно легко использовать электронное обучение с элементами мультимедийного контента (видеофильмы, музыка, изобразительное искусство, интернет ресурсы) - все, что реально может стимулировать и мотивировать, облегчить студентам изучение иностранного языка, сообщить знания более интересным, интерактивным способом.

Интерактивные методы для активного участия обучающихся: интерактивные занятия с тематическими обсуждениями и беседами; круглый стол; мозговая атака; тематический проект/исследование; деловые игры; ролевые игры; имитационные игры; бизнес-симуляция; групповые и индивидуальные закрепляющие материал упражнения. «Активные и интерактивные методы обучения, современное осмысление их сущностных характеристик невозможно без осознания необходимости применения информационных технологий, электронных учебников, интерактивных средств обучения (интерактивная доска), обеспечивающих активный обмен информацией между пользователем и информационной системой в режиме реального времени. Использование интерактивных средств направлено на взаимодействие пользователя с компьютером, оно «позволяет обучающимся 
управлять ходом обучения, регулировать скорость изучения материала, возвращаться на более ранние этапы» [1, с. 140].

Наша преподавательская деятельность в университете показывает, что много игр и презентаций на основе музыкальных, художественных произведений и живописи мотивируют обучающихся. Разработаны и используются авторские методические и учебные пособия, по которым эти методы активно апробируются.

Интервью, визуализация упражнений, портфолио, викторины сопровождают теоретическое содержание обучения, оптимизируя процесс общения, используя такие эффективные формы личностного взаимодействия, как: речевая цепочка из индивидуальных работ (заданий); обмен кругом интересов; описание реальной, ситуационной и желаемой деятельности с использованием тематического лексического и грамматического минимума; представляемая партнерская работа в бизнесе; командная работа в проекте и т.д. Преподаватель должен для каждой образовательной ситуации, для каждого уровня студента подбирать подходящий метод доступного усвояемого обучения, с учетом соответствующих дидактических намерений в преподавании иностранных языков: помочь условно воплотить в жизнь, профессионально применять языковые знания - ключевую компетенцию студентов неязыковых специальностей разного уровня.

Преобладающими формами закрепления грамматических и лексических правил являются правильно выстроенные тексты, содержащие пройденный материал и сравнительно-сопоставительный перевод, демонстрирующий корректное применение изученных правил. Перевод текстов с иностранного и на иностранный язык служит и основой культурологической компетенции владения языком, строящейся на правилах, которые можно свести к базовым схематическим структурам. 


\section{СТРАТЕГИЯ НАУЧНО-ТЕХНОЛОГИЧЕСКОГО РАЗВИТИЯ РОССИИ: ПРОБЛЕМЫ И ПЕРСПЕКТИВЫ РЕАЛИЗАЦИИ}

Цифровые технологии в сочетании с традиционными (слайд-проектор, кинопленка, видео и/или интерактивная доска) предоставляют для преподавателя возможности для разнообразных методических подходов в аудитории, специфичных и эффективных для конкретной группы обучения. Практикуемый широко когнитивный подход, или лингвистический (обучающий) метод традиционно может быть основой для методологической разработки языкового обучения и в сочетании с коммуникативным подходом способствовать лучшему развитию навыков общения между студентами / собеседниками (с использованием когнитивных, культурологических знаний и творческого подхода). Современный процесс обучения рассматривается прагматично, основное внимание рекомендуется уделять моделям различной вербализации речевых намерений. Учебный материал в максимально возможной степени ориентирован на группу обучающихся и учитывает их интересы, позволяет проводить занятия с привлечением студентов с разного уровня владения иностранным языком, с использованием различных форм работы, с учетом социального и психолого-педагогического сопровождения и измененной ролью преподавателя: не посредника, а носителя и примера образованности. Грамматика предлагается в схематическом, ситуативном контексте, закрепляется в регулярном повторении.

В последнее время на ведущее место стал претендовать межкультурный подход, который предусматривает сочетание когнитивного обучения (базовых навыков чтения и письма, а также понимание на слух и усвоение соответствующих языковых особенностей) со знакомством и презентацией культурологических знаний, что определенно дает хорошие результаты в привлечении заинтересованности студентов к изучаемому языку и расширении, обогащении их общей культуры. Аутентичные тексты служат как основой для диалогов-разговора (что-то должно быть обсуждено с партнерами собеседниками-студентами), так и для тематического сравнения ситуаций и 
поведения в соответствующей области, что эффективно приводит к лучшему пониманию особенности иноязычных носителей, их культуры, мышления, действий и связанного с этим языкового выражения. Постоянно корректируемые авторские методы обучения иностранному языку направлены на лучшую адаптацию к ним обучающихся различного уровня и, таким образом, наиболее оптимальный выбор метода обучения для конкретной целевой группы. Поэтому важно постоянно обновлять или расширять авторские методы обучения, модифицировать имеющиеся подходы.

В процессе обучения иностранному языку есть много факторов, влияющих на эффективность, одним из которых продолжает оставаться мотивация и студентов и преподавателя. Качество обучения иностранному языку определяется готовностью к определенному инокультурному действию и поведению, не обязательно совершенно новое обоснование, но обновленная, проявляющаяся как необходимость потребность, желание, побуждение, стремление, побуждение, все - как синонимы.

По-прежнему, мотивация - это отношение к процессу обучения, в котором цели действий обучения и поведение в результате приобретения опыта приведены в соответствие с коммуникативной, или лингвокультурологической, языковой целью. Такая мотивация проистекает из взаимодействия личности преподавателя, языковых ситуативных стимулов и мотивов. Дальнейшее определение мотивации означает, что это - фактор, на который влияют эмоции, такие как взаимоотношение, ориентация и эмоциональные состояния, например, страх не справится, или внешние обстоятельства, образовательный процесс, образовательная среда, формы, содержание, учебные материалы, личность преподавателя, однокурсники, одногруппники, даже влияние и настрой родителей, социальная среда, интенсивность обучения и т.д. 
Ключевым выводом является то, что мотивация - это индивидуальный, многомерный и динамический фактор. Центр внимания сосредоточен на практико-ориентированном применении, в котором выделяем:

1. Скорую интегративную ориентацию (возможны и другие факторы, но стремление к интеграции является самым мотивационным).

2. Индивидуальное стремление к культурной и языковой целостности и привлекательности.

1. Комплексное понимание процесса обучения и индивидуальная обучаемость.

2. Совместимость интереса к языку и культуры целевого языка.

3. Отношение к группе.

4. Личное отношение к ситуации обучения:

- оценка личности преподавателя и методики преподавания;

- мотивация и желание выучить язык;

- отношение к актуальности, важности, прагматичности изучаемого языка;

- степень интеграции обучающегося в поликультурную образовательную среду;

- общий интеллектуальный интерес к стране, языку, носителям и культуре изучаемого языка;

- позитивная атмосфера в образовательной среде;

- долгосрочные, перспективные цели изучения языка.

Отсюда следует, что мотивация основана на инструментальных и интегративных ориентациях. Инструментально мотивированные студенты рассчитывают на практическую пользу знания иностранного языка для дальнейшей жизни (например, лучшие возможности для работы, перспективы самореализации) и соблюдают обязательность, системность в обучении, контроль за обучением, нуждаются в стимуле, часто выходящем за пределы 
учебной задачи, признают ценность учебной деятельности и определяют ее выгодной).

Для интегративно мотивированных студентов, как правило, это интерес к иноязычным культурам и ценностям других народов, любопытство, любознательность, путешествия, удовольствие, определенное регулирование интереса.

Ориентации не должны быть взаимоисключающими. Для всех важны формы обучения - содержание и материалы, а также личность, методическая и дидактическая компетентность преподавателя, его отношение.

Если студент оперирует в основном, долгосрочными задачами, изучая иностранный язык, исходя из собственных интересов, и если он, может быть, планирует глубже изучать иную культуру, то речь идет об интегративной мотивации. Если к обучению подходить с точки зрения выгоды и пользы, например, чтобы улучшить профессиональные возможности, тогда это инструментальная мотивация.

Можно говорить также о внешней и внутренней мотивации. Внешняя мотивация требует от учащихся получения дополнительных стимулов, таких как поощрения в виде хорошей оценки, похвалы и т.д. Внутренняя мотивация изучения иностранного языка основывается на интересе и удовольствии от этого занятия.

На процесс обучения могут влиять:

- Задачи, которые должны преследовать дидактические цели, ориентированные на результат, позволяющие студентам активно участвовать в обучающем процессе.

- Факторы, которые также могут являются социально-культурным источником мотивации (родители, изменения в семье, общение со сверстниками, однокурсниками, одногруппниками и т.д.). 
- Возможности обучения (в вузе и вне, использование средств массовой информации, интернет ресурсы и т.д.),

- Условия, связанные с обучением иностранному языку (личность преподавателя, образовательная среда).

- Результаты обучения (влияют на мотивационный процесс и дальнейшее совершенствование компетенций.

- Отношение к изучению иностранных языков, которое часто поддерживается усилиями силой воли и внешними факторами.

Для каждой учебной группы разработаны тщательно продуманные требования к студенту, учитывающие мотивы, подразумевающие целенаправленный выбор предлагаемых методов обучения, а также диагностику прогресса в обучении. Следует поощрять и развивать учебную мотивацию, учебный настрой, что способствует автономии студентов, т.к. это студенты неязыковых специальностей, следовательно, иностранный язык не является центральным элементом в профессиональном обучении, но важным в дальнейшей реализации профессиональных интересов.

Два основных направления интересны для дидактики иностранных языков:

1) Контент обучающего материала - в нем фиксируются мотивы изучения иностранного языка.

2) Рефлексия обучающихся - характеризует появление мотивированных действий студентов.

Оба аспекта формируют многомерный и динамический характер мотивации для выполнения коммуникативных заданий по рефлексии контента текста. Чем сильнее мотивация, тем более ценной является цель, тем больше вероятность ее достижения, чему способствуют коммуникативные задания, выполняемые студентами.

Коммуникативная задание выполняется по нескольким направлениям: 
1) Определение тематического задания (словарь активирован, или указан).

2) Выполнение цикла задач (информативное ознакомление, выявление идеи, стратегия действий, планирование результата).

3) Анализ языковых и лексико-культурологических средств и их функций, которые сыграли свою роль в анализе текста (музыкального произведения, картины живописи и т.д.), оценка их эффективности и совершенствование.

4) Представление и оценка результата обучения (в рамках учебной группы: студент - преподаватель).

5) Обновление учебного материала и актуальной информации (анализ использованных аутентичных материалов, языкового ресурса (словарного запаса, оптимальных грамматических структур, произношения и т.д.)

6) Определение достаточности и необходимости расширения языковых ресурсов (активировать, практиковать, автоматизировать).

7) Определение компетенций студентов, необходимых для выполнения предложенного коммуникативного задания: понимание прочитанного (приближение к тому, что действия и мышление студентов в целостном процессе выполнения коммуникативного задания связаны; в практическом действии/активе использование навыков понимания аудирования; в результативном связи и взаимопродолжении стратегия и тактика обучения; прослеживаются технические, технологические, методологические, методические, культурологические, культурные и социальные навыки, которые они позже могут использовать в профессиональной работе.

8) Ориентированное на практическое использование обучение иностранному языку отражает субъективные интересы студента, отвечает их интересам. 


\section{СТРАТЕГИЯ НАУЧНО-ТЕХНОЛОГИЧЕСКОГО РАЗВИТИЯ РОССИИ: ПРОБЛЕМЫ И ПЕРСПЕКТИВЫ РЕАЛИЗАЦИИ}

Преподаватель может мотивировать студентов с помощью различных методов и подходов. Такая концепция обучения способствует развитию системного мышления и формированию переводческих (в рамках профессионального прикладного назначения и др.) языковых компетенций. На продвинутом этапе обучения студенты более независимы в своем мышлении и действии; они могут найти свою позицию, выразить, обосновать мнение и развить способность критического подхода к себе и другим.

Содержание обучающего учебного материала должно отвечать определенным требованиям, которые, в свою очередь, тесно связаны с контентом и его проявлением в конкретных коммуникационных ситуациях, характеризующихся разнообразной палитрой индивидуальных, социальных факторов. К ним относятся институциональные рамки, личностный опыт, языковая и текстовая компетентность, мотивация, а также личное отношение и эмоции. Иноязычный текст - это объект понимания информации разной сложности, к которому можно подходить с разных точек зрения. Цели познания, специфичные для дисциплины профессионального иностранного языка разных специальностей, влияющие на соответствующий подход к предмету, могут освещать разные фрагмент. Комплекс нескольких подходов (взглядов) позволяет создать более точную и тонкую, информативную картину анализируемых в контексте коммуникационных ситуаций в единстве правил межкультурной коммуникации с закреплением форм языковых действий, ориентированных на реализацию (отражение, выражение, модификацию) сознательного, целенаправленного поведения, с помощью которого предполагаются адекватный перевод, личностное взаимодействие, предметная коммуникация - как целостная языковая единица, из которой вытекает определенная интенция в соответствии с осознанным подходом к заданному авторскому коммуникативному заданию (с личностным подходом, восприятием и пониманием лингво-культурологичеких особенностей) в плане осознания 
качественных различий между сложностью текста и обучаемости на конкретных текстовых ситуациях. И тут имеет значение целеустремленность и осведомленность обучаемой аудитории, аргументированность в обмене мнениями. В профессионально-ориентированных специальных текстах возникает проблема определения вида/типа текста и соответствующего подбора средств общения: от формы интендантской (вспомогательной), рабочей коммуникации до конструктивного взаимопонимания. Тексты являются носителями предполагаемой, контентосодержащей коммуникацией и объектом возможного планируемого понимания, а не просто формой языковых образований, на которые реципиенты реагируют (или не реагируют) внутри в какой-либо (неопределимой) форме.

«В современных образовательных условиях чрезвычайно важны сетевые дистанционные образовательные технологии распространения знаний, средства виртуальной визуализации и интерактивный контент позволяют не только расширить потенциал ранее известных активных и интерактивных методов педагогического взаимодействия, но и разнообразить подачу учебного материала на основе использования современных ИКТ, вывести процесс освоения дисциплины на качественно новый уровень эффективности, увеличить привлекательность интерактивно изучаемого материала и напрямую включить обучающихся в деятельностную активность, расширить сферу образовательных услуг, радиус их действия, синхронно систематизировать и актуализировать методическое обеспечение учебного процесса [1, с. 230].

Понятие коммуникации трактуется широко и имеет место не только тогда, когда она намерена, осознана и успешна, но это и общение по стечению обстоятельств, случайное, как форма поведения. Таким образом, общение основано на индивидуальной интенциональности, и из этого следует, что не всякое общение завершается речевым действием, может быть осознанным и характеризовать сознательную сторону поведения. 


\section{СТРАТЕГИЯ НАУЧНО-ТЕХНОЛОГИЧЕСКОГО РАЗВИТИЯ РОССИИ: ПРОБЛЕМЫ И ПЕРСПЕКТИВЫ РЕАЛИЗАЦИИ}

Требования к профессиональным текстам сравнительны. Они выполняют (должны) коммуникативную функцию профессионального содержания, имеют дело с интендантской (облегчающей предметный разговор) вспомогательноснабженческой языковой, исключительно ориентированной на результат коммуникацией. Речевое действие происходит в коммуникативной ситуации с учетом текстовой рецепции (принятия приспособления) к иным социологическим и культурным формам и, следовательно, полилингвальной, перспективой ценностной ориентации в мировоззрении.

Устная коммуникация предусматривает многообразие языковых высказываний и связана с одновременным (онлайн или офлайн) присутствием собеседника.

Письменный текст позволяет преодолеть избегать невозвратности речевого действия и делает возможными конкретные характеристики: максимальный уровень качества лингвистического содержания, сокращение контекста, тематическую центрированность, структурированность и определенность форм, а также временное и пространственное языковое разделение предсказуемым, менее интерпретируемым, чтобы коммуникационное понимание не было пропущено. Возможность вникать в коммуникативную текстовую ситуацию дает студентам опыт, который поможет им в последующей профессиональной деятельности справиться с похожей реальной ситуацией: для этого требуется способность запоминать ситуацию общения в ее различных аспектах и соответствующим образом формировать целевой текст и решение коммуникативного задания.

Вопрос интерпретации - ситуационного толкования текста, является предметом согласования, в котором играют роль также и отношения сторон. Сосредоточение внимания на профессиональном контенте текста помогает заранее прогнозировать ситуацию и проанализировать условия корректности. Однако, от студента трудно много ожидать, невозможно заставить его 
понимать внутренний текст намеченных образом. Будет ли коммуникационное предложение принято, или нет, будет ли оно работать, или нет, зависит не только от «переводчиков», но и от характера языкового изложения текста (можно создать свое коммуникационное предложение таким образом, чтобы помочь его принять, или необходимо согласование смысла, как фактического контента коммуникации и грамотного понимания «функций, которые выполняют речь в каждой конкретной ситуации общения, определяют внешний вид высказывания, в первую очередь, отбор слов и синтаксических конструкций. Отсюда следует, что для успешного общения необходимо знать основной набор языковых средств, которые используются для выполнения тех или иных речевых функций» [3, с. 16].

В формировании коммуникационных предложений в профессиональных текстах важную роль играет их межличностная функция и, следовательно, опосредованная с помощью языковых средств текста взаимосвязь между автором и переводчиком. Профессиональный текст должен сводиться к максимально предметно приближенному контенту с элементами и формой соответствующего коммуникационного вмешательства, учитывая содержание информации, а также оформление сообщения, избегания ненужных усилий, нестабильности, неточности, поверхностного подхода к серьезной информации, не соответствующей цели профессионального общения. Текст научного характера в коротких вариантах, как правило, содержит максимум информации, насколько это возможно, и нужно, чтобы понимание было максимально вероятным. Особенностью такого корректного восприятия является интерсубъективная понятность коммуникативного предложения. «Исследование понятности учитывает аспекты на разных детализации и последовательности сведений, а также глубину описания, а также предварительные знания и интересы адресата» [4]. 
Известными моделями понятности является «гамбургская концепция понятности». Модель «Четырёх ушей», предложенная Лангер / Шульц фон Тун, описывает многоуровневый характер сообщений, отправляемых людьми в коммуникации:

«Уровень фактов содержит непосредственно те факты и данные о положении вещей, описанном в сообщении.

Уровень призыва к действию передает некое желание говорящего или призыв к какому-либо действию.

Уровень отношения выражает или вызывает восприятие отношения между собеседниками.

Уровень откровения («Я»-сообщение) передает «Я» говорящего сознательно или бессознательно» [5].

Концепция основана на четырех измерениях: простота, порядок/контур, краткость/лаконичность и часто используется в дидактических целях из-за ее легкой управляемости. Следует соблюдать текстовые требования на разных уровнях и иметь несколько коммуникационных стратегий по нескольким аспектам: профессиональному, социальному, познавательному, культурному и ориентироваться в языковых средствах для их реализации.

Заключение. С дидактико-методологической точки зрения в зависимости от функций, задач и цели обучения на неязыковых специальностях предъявляются в процессе обучения разные требования к материалу обучения. Требования к контенту аутентичных текстов: соответствие принципам поэтапного обучения, способствующего долгосрочной запоминаемости учебного материала (новых слов/словосочетаний, грамматических структур; приобретение и сохранение опыта распознания ценностного культурного содержания: корректность, системность и последовательность тематических упражнений в том или ином лингвистическом и культурологическом контексте; разъяснение видения различий культурно-специфических особенностей 
изучаемого языка и народа; дифференцированность в уровневом подходе к обучающему материалу; недопуск перегруженности студента при выполнении коммуникативных и когнитивных заданий (максимум и минимум должны быть контролируемыми); четко должна быть подчеркнутая целевая установка и оптимальное сочетание со временем выполнения заданий.

Ключевой вывод для овладения иностранным языком студентами неязыковых специальностей в том, что только понятный и доступный план, развивающий у студентов (начинающих и слабых в языковых знаниях) уверенность в себе, эффективен в обучении.

\section{Список литературы}

1. Бороненко Т.А. Активные и интерактивные методы педагогического взаимодействия в системе дистанционного обучения / Т.А. Бороненко, А.В. Кайсина, В.С. Федотова // Научный диалог. — 2017. — № 1. C. $227-243$.

2. Гуляева И.В. Активные и интерактивные методы обучения в преподавании математики в системе СПО / И. В. Гуляева // Психология и педагогика: методика и проблемы практического применения. - 2014. № 35/1. - C. $138-144$.

3. Попова Е. П. Бондаренко О. В. Кострулева И. В. Теория и практика профессиональной коммуникации на русском языке.- Учвебное пособие. Ставрополь : СКФУ 2017. 218 с. С. 16.

4. Göpferich et al. 2008 ... Research, ed. by Inger Mees, Fabio Alves, and Susanne Göpferich, Interdisciplinarity in Translation and Interpreting Process Research 267-292.ublished online: 07 September 2012 https://doi.org/10.1075/ target.24.1.13tir

5. Лангер / Шульц фон Тун /https://ru.wikipedia.org/w/index.php?title= Friedemann_Schulz_von_Thun\&action=edit\&redlink= 
УДК 373.24

Глава 5.

ФОРМИРОВАНИЕ ЭМОЦИОНАЛЬНОГО ИНТЕЛЛЕКТА

У ДЕТЕЙ В ПЕРИОД ДОШКОЛЬНОГО ВОЗРАСТА

Гордеева Вероника Викторовна

к.п.н., доцент

Назарова Александра Сергеевна

студент

Таланова Марина Викторовна

Аннотация: в работе говорится о том, что проблема формирования эмоционального интеллекта у подрастающего поколения в последнее время является довольно актуальной. Это обусловлено ускорением темпов жизни, что требует от человека большей адаптации к социуму. Для успешной реализации человека в жизни и деятельности важной становится способность качественно взаимодействовать с окружающими людьми. Актуальность данной проблемы также обусловлена потребностью общества в воспитании человека, демонстрирующего социальное поведение в духе общепринятых ценностей и норм. Начинать работу по формированию эмоционального интеллекта необходимо как можно раньше, и период дошкольного детства является наиболее благоприятным для ее осуществления.

Ключевые слова: эмоциональный интеллект, мышление, когнитивная сфера, эмоции, дошкольный возраст. 


\title{
FORMATION OF EMOTIONAL INTELLIGENCE IN CHILDREN DURING PRESCHOOL AGE
}

\section{Gordeeva Veronika Viktorovna Nazarova Alexandra Sergeevna Talanova Marina Viktorovna}

\begin{abstract}
: the paper says that the problem of the formation of emotional intelligence in the younger generation has recently been quite relevant. This is due to the acceleration of the pace of life, which requires a person to adapt more to society. For the successful realization of a person in life and activity, the ability to interact qualitatively with other people becomes important. The relevance of this problem is also due to the need of society to educate a person demonstrating social behavior in the spirit of generally accepted values and norms. It is necessary to start work on the formation of emotional intelligence as early as possible and the period of preschool childhood is the most favorable for its implementation.
\end{abstract}

Key words: emotional intelligence, thinking, cognitive sphere, emotions, preschool age.

В связи с новыми задачами, выдвинутыми обществом перед системой образования дошкольников, особую актуальность приобретает проблема формирования эмоционального интеллекта у детей дошкольного возраста.

На сегодняшний день вопрос изучения эмоционального интеллекта является крайне важным. Данный термин пользуется возрастающей популярностью, но в науке до сих пор нет четкого определения этого понятия. Исследование данного феномена началось в 1990 г., когда два американских профессора Дж. Мэйер и П. Сэловей впервые ввели термин «эмоциональный 
интеллект». По их мнению, эмоциональный интеллект означает способность воспринимать и выражать эмоции, ассимилировать мысли и эмоции, понимать и объяснять эмоции, а также регулировать свои собственные эмоции и эмоции других людей [12].

Д. Гоулман также был в числе первых, кто занимался изучением эмоционального интеллекта, своими работами он смог заинтересовать многих ученых. Д. Гоулман обозначает эмоциональный интеллект как «способность человека истолковывать собственные эмоции и эмоции окружающих с тем, чтобы использовать полученную информацию для реализации собственных целей».

В своей книге «Эмоциональный интеллект» Д. Гоулман ясно доказывает, что более эффективны в работе люди, которые могут одновременно сочетать разум и чувства. Именно люди с высоким эмоциональным интеллектом лучше принимают решения, эффективнее действуют в критических ситуациях и лучше управляют своими подчиненными, что, соответственно, и способствует их росту по служебной лестнице [9].

Из отечественных авторов эмоциональный интеллект более подробно изучал Л.С. Выготский. Он пришел к выводу о существовании динамической смысловой системы, которая представляет единство интеллектуальных и аффективных процессов: «Как известно, отрыв интеллектуальной стороны нашего сознания от его аффективной, волевой стороны, представляет один из основных и коренных пороков всей традиционной психологии. Мышление при этом неизбежно превращается в автономное течение себя мыслящих мыслей, оно отрывается от всей полноты живой жизни...» [6].

Развивая идеи Л.С. Выготского, С.Л. Рубинштейн подчеркивал, что мышление уже само по себе является единством рационального и эмоционального, также, как и эмоция является единством аффективного и интеллектуального. Однако, на сегодняшний день тема, затронутая 
Л.С. Выготским и С.Л. Рубинштейном, о единстве интеллекта и аффекта в процессе развития человека, пока не исследована должным образом в отечественной психологии. $\mathrm{K}$ сожалению, намеченные Л.С. Выготским подходы к пониманию единства аффекта и интеллекта в процессе развития человека в свое время не получили должной разработки [14].

Из вышеперечисленных определений становится понятно, что на сегодняшний день ученые так и не пришли к единому пониманию «эмоционального интеллекта», поэтому существует множество его характеристик и моделей.

Одной из них является модель Дж. Мейера и П. Сэловея, разработанная в 1997 г., согласно которой эмоциональный интеллект включает следующие ментальные способности:

1) способность безошибочно воспринимать, оценивать и выражать эмоции - это первоначальный, основной компонент, имеющий отношение к невербальному восприятию и выражению эмоций. Выражения лиц, отображающих счастье, печаль, гнев и страх универсальны для распознавания этих эмоций $\mathrm{y}$ всех людей. Младенцы и маленькие дети учатся идентифицировать свои и чужие эмоциональные состояния и отличать их друг от друга. Вначале младенец отличает эмоциональные выражения лица родителя и отвечает на них. С возрастом ребенок более точно идентифицирует свои собственные мускульные и физические ощущения и окружающую среду. А зрелый человек уже может тщательно контролировать свои внутренние ощущения. Способность безошибочно воспринимать эмоции, отображаемые на лице или в голосе другого человека, обеспечивает решающую отправную точку для более тонкого понимания эмоций;

2) способность иметь доступ и вызывать чувства, чтобы повысить эффективность мышления - этот компонент является таким же основополагающим, как и первый. Он отражает способность эмоций 
ориентировать познавательную систему и содействовать мышлению. Включает способность использовать эмоции для направления внимания на важные события, вызывать эмоции, которые способствуют решению задач. Например, позитивный настрой участвует в реализации творческой мысли, а колебание настроения можно использовать как средство анализа разных точек зрения на проблему;

3) способность к пониманию эмоций, эмоциональному познанию: эмоции передают информацию (счастье обычно указывает на желание объединиться с другими людьми; гнев указывает на желание напасть или вредить другим; страх указывает на желание убежать, и т.д.). Каждая эмоция передает свой собственный образец возможных сообщений и действий, связанных с этими сообщениями. Понимание эмоциональных сообщений и действий, связанных с ними, является одним важным аспектом этой области навыка. Как только человек сможет идентифицировать такие сообщения и потенциальные действия, способность рассуждать об эмоциональных сообщениях и действиях становится также важной. Другими словами, полное понимание эмоций вызывает понимание значения эмоций вкупе со способностью рассуждать об этих значениях. Это является важным моментом в отношении этой группы эмоционально-интеллектуальных навыков;

4) способность к осознанной регуляции эмоций, управлению эмоциями, повышению уровня эмоционального и интеллектуального развития. Эмоциями часто можно управлять. Человек должен понять, что эмоции передают информацию. В определенных пределах, когда эмоции находятся под контролем, человек может быть открыт для самых различных эмоциональных сигналов до тех пор, пока не появятся наиболее сильные, подавляющие остальные. В пределах эмоциональной зоны комфорта человека становится возможной регуляция и управление собственными эмоциями и эмоциями 
других - для того, чтобы продвинуться к достижению собственных личных и социальных целей других людей [12].

Таким образом, способность распознавать и выражать эмоции, является необходимой основой для порождения эмоций в целях решения конкретных задач. Эти две способности являются основой для декларативной способности к пониманию событий, предшествующих эмоциям и следующих за ними. Bсе вышеописанные способности необходимы для внутренней регуляции собственных эмоциональных состояний и для успешных воздействий на внешнюю среду, приводящих к регуляции собственных и чужих эмоций.

Вышеуказанная модель Дж. Мейера и П. Сэловея, созданная в 1997 г., не была единственной. В 1990-е годы появились и другие модели эмоционального интеллекта, которые определяли его, как сочетание когнитивных и личностных характеристик. Такие модели получили название смешанных. Смешанные модели были рассчитаны на измерение эмоционального интеллекта с помощью опросников, подобных традиционным, и основанным на самоотчете. Приверженцами данной теории являются Д. Гоулман и Р. Бар-Он. Д. Гоулман создал свою концепцию эмоционального интеллекта, опираясь на представления Дж. Мэйера и П. Сэловея, добавив личностные характеристики (социальные навыки, настойчивость и энтузиазм) к выделенным ими компонентам.

Структура эмоционального интеллекта Д. Гоулмана иерархична и состоит из пяти компонентов:

1) идентификация и называние эмоциональных состояний, понимание взаимосвязей между эмоциями, мышлением и действием;

2) управление эмоциональным состоянием - контроль эмоций, замена нежелательных эмоций на желаемые;

3) способность достигать эмоциональных состояний, содействующих успеху; 
4) способность идентифицировать эмоции других людей, быть чувствительным к ним, а также управлять эмоциями других;

5) способность вступать в благоприятные межличностные отношения с другими людьми и поддерживать их.

Как уже было сказано выше, модель эмоционального интеллекта Д. Гоулмана иерархична. А это означает, что идентификация эмоций является предпосылкой управления ими. Способность достигать эмоциональные состояния, содействующие успеху, зависит от умения грамотно управлять своими эмоциями и т.д. Позднее Д. Гоулман решил доработать структуру эмоционального интеллекта. В данный момент она состоит из четырех компонентов: самосознание; самоконтроль; социальное понимание; управление взаимоотношениями [8].

В 2004 г. российский психолог Д.В. Люсин предложил принципиально новую модель эмоционального интеллекта [15]. Эмоциональный интеллект автор определяет как способность к пониманию своих и чужих эмоций и управлению ими. Под способностью к пониманию и управлению эмоциями Д.В. Люсин понимает следующее:

1) способность к пониманию эмоций означает, что человек:

- может распознать эмоцию, т.е. установить сам факт наличия эмоционального переживания у себя или у другого человека;

- может идентифицировать эмоцию, т.е. установить, какую именно эмоцию испытывает он сам или другой человек, и найти для нее словесное выражение;

- понимает причины, вызвавшие данную эмоцию, и последствия, к которым она приведет;

2) способность к управлению эмоциями означает, что человек:

- может контролировать интенсивность эмоций, прежде всего, приглушать чрезмерно сильные эмоции; 
- может контролировать внешнее выражение эмоций;

- может при необходимости произвольно вызвать ту или иную эмоцию.

Способность к пониманию, и способность к управлению эмоциями может быть направлена и на собственные эмоции, и на эмоции других людей, то есть можно говорить как о внутриличностном, так и о межличностном эмоциональном интеллекте. Эти два варианта предполагают актуализацию разных когнитивных процессов и навыков, однако должны быть связаны друг с другом.

Д.В. Люсин считает неправильным трактовку эмоционального интеллекта как чисто когнитивной способности и предполагает, что способность к пониманию эмоций и управлению ими тесно связана с общей направленностью личности на эмоциональную сферу, т.е. с интересом к внутреннему миру людей (в том числе и к своему собственному), склонностью к психологическому анализу поведения, с ценностями, приписываемыми эмоциональным переживаниям. Поэтому, как отмечает автор, эмоциональный интеллект можно представить как конструкт, имеющий двойственную природу и связанный, с одной стороны, с когнитивными способностями, а с другой стороны - с личностными характеристиками. Эмоциональный интеллект, по Д.В. Люсину это психологическое образование, формирующееся в ходе жизни человека под влиянием ряда факторов, которые обуславливают его уровень и специфические индивидуальные особенности.

Автор указывает на три группы таких факторов:

1) когнитивные способности (скорость и точность переработки эмоциональной информации);

2) представления об эмоциях (как о ценностях, как о важном источнике информации о себе самом и о других людях);

3) особенности эмоциональности (эмоциональная устойчивость, эмоциональная чувствительность и т. д.) [15]. 
Принципиальные отличия описанных выше моделей эмоционального интеллекта состоят в следующем. Модель П. Сэловея и Дж. Мэйера, возникшая первой, включает в себя только когнитивные способности, связанные с переработкой эмоциональной информации. Поэтому она была определена авторами как модель способностей.

Д. Гоулман соединил когнитивные способности, входившие в модель П. Сэловея и Дж. Мэйера, с личностными характеристиками. По этой причине Дж. Мейер и П. Сэловей считают модель эмоционального интеллекта Д. Гоулмана неудачной, «так как в нее включены отдельные психологические качества, концептуально и эмпирически не зависимые друг от друга» [12].

Модель Д.В. Люсина принципиально отличается от смешанных моделей тем, что в конструкт не вводятся личностные характеристики, которые являются коррелятами способности к пониманию и управлению эмоциями. Допускается введение только таких личностных характеристик, которые более или менее прямо влияют на уровень и индивидуальные особенности эмоционального интеллекта.

Таким образом, анализ теоретических воззрений вышеуказанных авторов позволяет определить эмоциональный интеллект как совокупность эмоционально-когнитивных способностей к социально-психологической адаптации личности. Все структурные компоненты эмоционального интеллекта взаимосвязаны, а их тесная взаимозависимость способствует эффективному межличностному взаимодействию. Люди с высоким уровнем развития эмоционального интеллекта обладают выраженными способностями к пониманию собственных эмоций и эмоций других людей, могут управлять своей эмоциональной сферой, что обусловливает их более высокую адаптивность и эффективность в общении, они легче добиваются своих целей во взаимодействии с окружающими. 


\section{СТРАТЕГИЯ НАУЧНО-ТЕХНОЛОГИЧЕСКОГО РАЗВИТИЯ РОССИИ: ПРОБЛЕМЫ И ПЕРСПЕКТИВЫ РЕАЛИЗАЦИИ}

Дошкольный возраст - время активного познания окружающего мира, смысла человеческих отношений, осознания самого себя, своего «Я» в системе мира, развития познавательных способностей. Ребенок не может стать частью социума, если не овладел теми знаниями, умениями, способностями, отношениями, которые существуют в человеческом обществе. Все это он может освоить только в общении с другими людьми - носителями общественного опыта.

Предназначение дошкольного детства заключается не столько в овладении ребенком знаниями, сколько в становлении базовых свойств его личности: самооценки и образа «Я», эмоционально-потребностной сферы, а также социально-психологических особенностей в системе отношений с другими людьми.

В последние годы в системе воспитания и обучения старших дошкольников все больше стала прослеживаться тенденция к интеллектуальному развитию ребенка.

Интеллектуальное развитие дошкольников - многогранный процесс, связанный с развитием всех сторон личности ребенка. Оно является важнейшей составной частью общего психического развития, подготовки к школе и ко всей будущей жизни. Осуществляется в результате воздействия на ребенка обстоятельств жизни и среды. Ведущая роль в интеллектуальном развитии принадлежит систематическому интеллектуальному воспитанию.

Интеллектуальное развитие, в зависимости от возраста имеет несколько стадий. В конце первого - начале второго года жизни, пока ребенок не овладел активной речью, ему присуще наглядно-действенное мышление. В этом возрасте он наглядно и активно знакомится с окружающей действительностью с помощью тактильного изучения предметов.

У дошкольников в возрасте 4-6 лет уже просыпается наглядно-образное мышление. То есть, дошкольники мыслят наглядными образами и при этом еще 


\section{СТРАТЕГИЯ НАУЧНО-ТЕХНОЛОГИЧЕСКОГО РАЗВИТИЯ РОССИИ: ПРОБЛЕМЫ И ПЕРСПЕКТИВЫ РЕАЛИЗАЦИИ}

не знакомы с конкретными понятиями. Мышление детей на этом этапе подчинено их восприятию.

Таким образом, интеллектуальное развитие ребенка делится на несколько периодов, где каждый предыдущий создает фундамент для последующего [1].

Основой для полноценного развития интеллекта ребенка является хорошо развитая эмоциональная сфера. Но, к сожалению, развитию эмоциональной сферы в дошкольном возрасте часто уделяется недостаточное внимание. Как справедливо указывали Л.С. Выготский и А.В. Запорожец: «только согласованное функционирование этих двух систем - эмоциональной сферы и интеллекта, их единство, могут обеспечить успешное выполнение любых форм деятельности» [7].

Умственное развитие ребенка тесным образом связано с особенностями мира его чувств и переживаний. Дети часто не могут управлять своими чувствами. Неумение их правильно выразить, скованность, неловкость или неадекватность мимико-жестовой речи - все это приводит к импульсивности поведения, осложнениям в общении со сверстниками и взрослыми.

Как известно, дошкольник живет эмоциями, руководствуется ими при выборе способов поведения. Эмоции сопровождают его ощущения, практические действия, делают окружающий мир многоликим, удивительно прекрасным и значимым. Благодаря эмоциям детство остается незабываемым периодом жизни [2].

Проблема развития эмоционального интеллекта является актуальной для дошкольного возраста. Анализ образовательных программ, разработанных для ДОО, показывает, что большое внимание в них уделяется развитию когнитивной сферы. Это обусловлено и социальным заказом, и значительной теоретико-методической обеспеченностью при внедрении подобного рода разработок. При этом упускается очень важный момент - целенаправленное развитие эмоциональной сферы, в том числе, эмоционального интеллекта [5]. 


\section{СТРАТЕГИЯ НАУЧНО-ТЕХНОЛОГИЧЕСКОГО РАЗВИТИЯ РОССИИ: ПРОБЛЕМЫ И ПЕРСПЕКТИВЫ РЕАЛИЗАЦИИ}

Эмоциональная сфера является составной частью эмоционального интеллекта. Рассмотрим становление данной сферы в онтогенезе.

Эмоциональной реакцией ребенка в первые месяцы жизни в норме является комплекс оживления, который представляет собой совокупность положительных эмоциональных проявлений, возникающих при восприятии им радующих воздействий. Именно благодаря эмоциональному общению с матерью у ребенка формируется первый аффективный опыт. Поведение 3-месячных младенцев показывает, что они настроены воспринимать эмоции на лице взрослого.

Выявлено также, что эмоциональные реакции удовольствия и неудовольствия наблюдаются уже у пяти-шестимесячного ребенка. Далее с возрастом возникают нестойкие образные представления о действительности с переживаниями: удовлетворения - неудовлетворения, приятного неприятного. Из этого следует, что эмоции развиваются в тесной связи с органическими потребностями, качеством их удовлетворения.

Во втором полугодии у детей начинает проявляться страх незнакомых людей, который продолжается примерно до 2-х лет. В 2-3 года появляются такие чувства как ревность и зависть. В 3-5 лет стыд соединяется с эмоцией страха и превращается в страх осуждения [3].

Известно, что маленькие дети используют один и тот же термин для обозначения более широкого круга эмоциональных явлений, чем старшие дети. По данным П. Харриса, в 5 лет дети начинают привязывать эмоцию к вызывающей ее ситуации. Только позже у детей появляются представления о внутренних состояниях, опосредствующих связь между ситуацией и эмоциональной реакцией. В основном этот процесс проявляется после 7-ми лет [4]. 
Вышеуказанный процесс был изучен А.М. Щетининой, которая исследовала 4-7-летних детей. Ею были выявлены следующие типы восприятия эмоций по экспрессии:

- довербальный: нет словесного опосредования эмоций, определение эмоций при соответствии с конкретной ситуацией;

- диффузно-аморфный: называние эмоций, но при этом восприятие осуществляется поверхностно, недифференцированно;

- диффузно-локальный: предыдущему процессу сопутствует выделение отдельного элемента экспрессии (глаза);

- аналитический: большое внимание уделяется выражению лица, а не позе;

- синтетический: целостное восприятие эмоциональных состояний;

- аналитико-синтетический: обобщение элементов экспрессии - мимики в целом [16].

На протяжении старшего дошкольного возраста эмоции и чувства детей изменяются не только количественно, но и качественно. По исследованиям Т.Б. Пескаровой, в этом возрасте дети легче понимают эмоции, которые проявляются в знакомых жизненных ситуациях. Старшие дошкольники лучше распознают положительные эмоции, нежели отрицательные. Эмоции страха и удивления для них неразличимы. Также они не в состоянии опознать эмоцию вины [13].

Как указывалось выше, развитие эмоциональной сферы значительно влияет на уровень формирования эмоционального интеллекта. Эмоциональный интеллект для детей старшего дошкольного возраста определяется, как готовность ребенка ориентироваться на другого человека и учитывать его эмоциональное состояние в своей деятельности.

Компоненты структуры эмоционального интеллекта в старшем дошкольном возрасте: 
1) направленность внимания ребенка к миру людей и миру эмоций;

2) эмоциональная ориентация ребенка на другого;

3) готовность ребенка учитывать эмоциональное состояние другого в своей деятельности.

Одним из компонентов эмоционального интеллекта является готовность ребенка учитывать эмоциональное состояние другого в своей деятельности. С самого рождения этой способностью человек не обладает. Доказательством этому выступает факт, что маленькие дети неадекватно воспринимают эмоции других. Данная способность развивается в процессе формирования личности. Легким для восприятия по лицевой экспрессии является эмоция ужаса, затем отвращение и удивление. Отсюда следует, что для понимания эмоций необходимо специальное обучение. Именно это способствовало появлению нового вида интеллекта - эмоционального [4].

Начать формировать эмоциональный интеллект можно у детей старшего дошкольного возраста. Для этого потребуется большая работа. Но в настоящее время все больше можно заметить односторонность внимания педагогов к совершенствованию когнитивных процессов, что ведет к существенному ухудшению коммуникативного и личностного развития ребенка.

По мнению Е.П. Ильина, в ходе формирования у старших дошкольников эмоционального интеллекта осуществляется работа по управлению своей экспрессией. Она реализуется в трех формах: первая из них - это «подавление», задача которой заключается в сокрытии выражения переживаемых эмоциональных состояний. Вторая - «маскировка», основная задача - заменить одну эмоцию на другую, которая не переживается в данный момент. Последней формой выступает «симуляция» - выражение не переживаемых эмоциональных состояний [10]. 
В процессе работы над формированием эмоционального интеллекта детям также даются знания о способах устранения нежелательного эмоционального состояния, среди которых К.Э. Изард отмечает три основных:

1) посредством другой эмоции;

2) когнитивная регуляция - переключение сознания на события и деятельность, вызывающие у человека позитивные эмоции;

3) моторная регуляция - физическая активность для снятия возникшего эмоционального напряжения [11].

Таким образом, можно утверждать, что формирование эмоционального интеллекта у детей дошкольного возраста оказывает влияние на развитие познавательных процессов, эффективность межличностного взаимодействия, повышает культуру общения, способствует развитию эмпатичного поведения и рефлексии, что обусловливает общую успешность ребенка в будущем.

\section{Список литературы}

1. Айзенк Г.Ю. Интеллект: новый взгляд. // Вопросы психологии. 1995. - № 1. - C. 111-131.

2. Ананьев Б.Г. О проблемах современного человекознания. - СПб.: Питер, 2001. - 272 c.

3. Андреева И.Н. Эмоциональный интеллект: исследование феномена. // Вопросы психологии. - 2011. - №3. - С. 78-86.

4. Андреева И.Н. Эмоциональный интеллект: непонимание, приводящее к «исчезновению». // Психологический журнал. - 2006. - №1 . - С. 28-32.

5. Вилюнас В.К. Психология эмоциональных явлений. - М., 2011. $143 \mathrm{c}$.

6. Выготский Л.С. История развития высших психических функций. // Собрание сочинений: в 6 т, Т. 2. - М.: Педагогика, 1983. - 368 с.

7. Выготский Л.С. Мышление и речь. - М.: Педагогика, 1999. - 352 с. 
8. Гоулман Д., Бояцис Р., Макки Э. Эмоциональное лидерство: искусство управления людьми на основе эмоционального интеллекта. - М.: Альпина Бизнес Букс, 2013. - 22 с.

9. Гоулман, Д. Эмоциональный интеллект. - М.: АСТ Москва: Хранитель, 2012. - 478 с.

10. Ильин Е.П. Эмоции и чувства. - СПб.: Питер, 2011. - 242 с.

11. Комкова Е.И., Недвецкая Т.М. Идентификация эмоций как показатель эмоционального интеллекта у старших дошкольников. // Инновационные образовательные технологии. - 2012. - №1. - С. 53-58.

12. Мэйер Дж., П. Сэловей, Д. Карузо. Эмоциональный интеллект. - М.: Институт психологии РАН, 2010. - 146 с.

13. Панкратова А.А. Практический, социальный и эмоциональный виды интеллекта. www.psystudy.ru

14. Рубинштейн С.Л. Проблемы общей психологии. - М.: Педагогика, 1996. - 416 c.

15. Современные представления об эмоциональном интеллекте. / Под ред. Д.В. Люсина, Д.В. Ушакова. - М.: Институт психологии РАН, 2012. - 29 с.

16. Юркевич В.С. Проблема эмоционального интеллекта. // Практическая психология образования. - 2012. - №3. - С. 4-10.

(C) В.В. Гордеева, А.С. Назарова, М.В. Таланова, 2022 


\title{
УДК 811
}

\section{Глава 6.}

\section{ЭТИМОЛОГИЧЕСКИЙ АНАЛИЗ АНГЛИЙСКИХ ПАРЕМИЙ С КОМПОНЕНТОМ «ЈАСК»}

\begin{abstract}
Котова Елена Геннадьевна к.П.н., доцент

Государственный гуманитарно-технологический университет Линева Елена Александровна к.ф.н., доцент Государственный гуманитарно-технологический университет Савельева Елена Борисовна к.ф.н., доцент Государственный гуманитарно-технологический университет Юсупова Татьяна Геннадьевна к.П.н., доцент Государственный гуманитарно-технологический университет Леонтьева Алесья Вячеславовна к.ф.н., доцент Московский городской педагогический университет

Аннотация: Статья посвящена изучению происхождения английских
\end{abstract} пословиц с компонентом именем собственным с позиции лингвокультурологии. Имя Джек в полной мере отображает специфичность английской нации, а знание этимологии паремий помогает понять ценностный характер сложившихся национально - культурных стереотипов в языковой картине мира. 
Ключевые слова: пословица, имя собственное, Джек, этимология, языковая картина мира.

\title{
ETYMOLOGICAL ANALYSIS OF ENGLISH PAROEMIAS WITH THE "JACK" COMPONENT
}

\author{
Kotova Elena Gennadievna \\ Lineva Elena Aleksandrovna \\ Savelieva Elena Borisovna \\ Yusupova Tatiana Gennadievna \\ Leontieva Alesya Vyacheslavovna
}

\begin{abstract}
The article is devoted to the study of the origin of English proverbs with a proper name component from the position of cultural linguistics. The name Jack fully reflects the specificity of the English nation, and knowledge of the etymology of the paremias helps to understand the value character of the prevailing national and cultural stereotypes in the linguistic picture of the world.
\end{abstract}

Key words: proverb, proper name, Jack, etymology, linguistic picture of the world.

Языковая картина мира как совокупность наших представлений о мире динамична и подвижна, она отражает результаты социальной и познавательной деятельности человека и сохраняет бесценный опыт поколений. Складываясь как мозаичный рисунок, она зависит от культурно-национальных особенностей носителей конкретного языка, ибо каждая из картин мира задаёт своё видение языка и культуры.

Народный фольклор представляет собой чрезвычайно важный и интересный материал для исследования человеческого мировидения. 
Пословицы, как зеркало, отражают жизнь и нравственные устои общества и действуют в обществе в качестве регулирующих «жизненных правил» $[1$, с. 50]. Характер нации отражается в языке, который, в свою очередь, представляет собой «объединенную духовную энергию народа» и воплощает в себе своеобразие целого народа, язык выражает определенное видение мира, а не просто отпечаток идей народа» [2, с. 370]. Таким образом, Гумбольдт одним из первых подчеркнул национальное содержание языка и мышления, отмечая, что «различные языки являются для нации органами их оригинального мышления и восприятия» [2, с. 324].

Важной и отличительной особенностью фольклора является его традиционализм и устный способ передачи [3, с. 124].

Паремии, как единицы языка, выдержали испытание временем, аккумулировав в себе мудрость и житейский опыт народа, глубинные черты его менталитета. Войдя в корпус пословичного фонда, пословицы в силу своей человеческой сущности, рассматриваются как часть отдельной лингвокультуры и в то же время составляют общую языковую картину мира. Исследователи пословиц, как правило, отмечают яркость проявления в паремиологических единицах совокупности умственных, эмоциональных, культурных особенностей, ценностных ориентаций, присущих любой этнической группе, нации, народу, народности. Однако, чтобы понять смысл пословицы, необходимо как минимум знать ее этимологию. Особую трудность в правильной интерпретации паремии представляют выражения, в которые включен с компонент - имя собственное.

Прямое назначение имени собственного - выделение конкретного объекта из ряда однотипных. Отдельно взятый индивид - это, прежде всего, человек с набором специфических черт и особенностей характера. Каждому человеку с рождения дается имя, получив которое, он становится личностью. С каждым именем ассоциируются определённые черты характера, например, 
Константин - постоянный, стойкий, Андрей - мужественный, храбрый. Имя может выступать в качестве обобщающего для представителей отдельно взятой нации, например, все русские в глазах иностранцев Иваны. Иван, как правило, это человек, сочетающий в себе такие качества, как сила, ловкость, остроумие, находчивость («Иван мал, но удал»). При всём том, нередки случаи, когда щедрость Ивана легко может перейти в транжирство, веселость и легкость в бесшабашность и безответственность, а доверчивость в глупость. («На Ваньке далеко не уедешь»; «С именем Иван, без имени - болван»; «Иван в дудку играет, а семья с голоду умирает»). Немцев называют очень распространённым именем Гансы («Was Hans für wahrhält, ist dem Franzke in Bargeld» (Tо, что Ганс считает правильным, то для Франца не наличные деньги); «Hans im Glück» (Счастливчик Ганс); «HansTaps» (Ганс - недотёпа); «Hans Guck in die luft» (Человек, который не смотрит куда идет ).

Однако нередко имена собственные в составе паремии либо частично объясняют ее смысл, либо вообще не подлежат толкованию. Прежде чем изучать пословицы с точки зрения их этимологии, рассмотрим английское имя Джек (Jack) изолировано от контекста.

Можно предположить, что Джек является разговорной формой мужского имени Джон (John), которое имеет семитские корни и произошло от древнееврейского «Йоханаан» (Johannes), означающего «Бог (Яхве) милостив». Джон был среди самых распространенных мужских имен в Великобритании и Уэльса с 1550 года до середины XX века, но к 2004 году он выпал из топ-50 имен для новорожденных мальчиков. По разным причинам это имя также не пользуется популярностью среди членов королевской семьи.

В XIV веке Джон Гауэр (John Gower, 1330-1408) создает поэтическое произведение «Confessio Amantis» («Исповеди влюблённого»), не уступающее по сюжетному разнообразию и поэтическому мастерству «Кентерберийским рассказам» [4]. В лучших традициях средневековой новеллистической 
литературы автор добивается создания художественной целостности произведения на основе объединения многочисленных разноплановых персонажей, сюжетов, тем и жанров. Причину дисгармонии мира Джон Гауэр видел в греховном поведении каждого отдельного человека, независимо от сословия, будь он представителем государственного аппарата, церковного института или народных масс [4]. Одним из таких героев, наряду с испанским королем Альфонсом, Александром Великим, папой Бонифацием является простолюдин Jacke, который тоже грешен, только по-своему.

Therwhile he hath his fulle packe, Theyseie, 'A good felawe is Jacke' $[5$, c. 802$]$.

На протяжении ряда столетий в Англии именно Jack символизировал простого человека; парня, паренька, простофилю, подобно Jock в Шотландии, поэтому мы можем предположить, что поэт выбрал это имя неслучайно.

Имя Джек в значении «разбойник» (young rogue) восходит к XVI веку. Ранний пример подобного употребления в английской художественной литературе можно найти в пьесе «Укрощение строптивой» (The Taming of the Shrew, 1590-1592) У. Шекспира (William Shakespeare). Действие сцены 1 второго акта происходит в доме Баптисты, местного дворянина, который безуспешно пытается найти мужа для старшей дочери Катарины, известной своим буйным нравом. Катарина возмущена тем фактом, что отец готов отдать ее замуж даже за разбойника, нахала и грубияна. В данном контексте имя Джек употребляется скорее, как нарицательное, чем собственное.

Call you me daughter? now, I promise you

You have show'd a tender fatherly regard,

To wish me wed to one half lunatic;

A mad-cup ruffian and a swearing Jack,

That thinks with oaths to face the matter out. (Act II. Scene I. Padua. A room in Baptista's house) [6]. 
И вы меня еще зовете дочкой!

Так вот отиовская забота ваша -

Меня за полоумного просватать,

Разбойника, нахала, грубияна,

Что наглостью рассчитывает взять! [7].

Перейдем к анализу английской пословицы «Jack of all trades, master of none». Как известно, первоначально существовала только первая часть данной паремии. «Jack of all trades» имело положительную коннотацию, называя человека умельцем, специалистом, профессионалом, который все умеет делать хорошо (ср. русск. «Мастер на все руки», «И швец, и жнец, и на дуде игрец»). Но вскоре пословица получает продолжение в виде второй части «master of none», и прежнее значение паремии полностью меняется. Теперь она звучит унизительно, осуждающе, пренебрежительно и употребляется по отношению к человеку, который ничего толком делать не умеет.

В 1592 году Роберт Грин (Robert Greene, 1558-1592) драматург и памфлетист времен королевы Елизаветы Английской и известный очень жесткой и негативной критикой своих коллег, в брошюре «Остроумие Грина» (Greene's Groats-Worth of Wit) [8] называет Уильяма Шекспира второсортным писателем («Johannes factotum»), что по своему значению вполне сопоставимо с коннотацией исследуемой пословицы. По мнению Грина, Шекспир, не имеющий университетского образования, не достоин стоять в одном ряду с Кристофером Марлоу (Christopher Marlowe), Томасом Нэшем (Thomas Nashe), да и самим Грином.

An upstart crow, beautified with our feathers, that supposes he is as well able to bumbast out a blanke verse as the best of you. Beeing an absolute Johannes fac totum, is in his owne conceit the onely Shake-scene in a countrey" [8].

Не верьте им; есть выскочка-ворона средь них, украшенная нашим опереньем, кто «с сердием тигра в шкуре лицедея» считает, что способен 
помпезно изрекать свой бельй стих, как лучшие из вас, и он - чистейший «мастер на все руки» - в своем воображеньи полагает себя единственным потрясателем сцены в стране [9].

«An upstart crow» (ворона в павлиньих перьях), "Shake-scene" (потрясатель сцены), «Johannes factotum» - такими далеко нелестными выражениями Грин наградил начинающего Шекспира. "Johannes factotum" (Мастер на все руки) звучит в данном контексте довольно иронично. Речь, вероятно, идет о человеке, который за все готов хвататься, но ничего толком не умеет. У Грина написано примерно следующее: «и будучи законченным Johannes-Factotum, в своем больном воображении видит себя одного (единственным, уникальным) потрясателем сценических декораций» [10].

Как мы указывали выше, Джек является производным от Джон или Джонни. Йоханнес (Johannes) - это средневековая латинская форма личного имени, которое в англоязычных контекстах обычно обозначается как «Джон». Так как этим именем награждали людей низшего сословия английского общества, и считали невоспитанными и необразованными, то, видимо, популярный драматург, написавший эту фразу, намекал на Шекспира, который изо всех сил в самом начале своей карьеры старался быть и актером, и драматургом одновременно, но, похоже, не был хорош ни в том, ни в другом. Более того, простой актер, как считает Грин, имел наглость выдавать себя за универсального гения («мастер на все руки»), который, сочиняя ходульные и напыщенные белые стихи, пытается соперничать с теми, кто выше его, и лишить их тем самым заработка. Многие толковали этот отрывок именно в таком смысле [10]. Сам памфлет звучит очень оскорбительно и, к слову сказать, содержит злобные выпады Грина не только против Шекспира, «актёра с повадками джентльмена», но и своих же товарищей по перу.

В 1618 году выходит в свет книга Джефри Миншула (Geffray Minshull) «Essayes and characters of a prison and prisoners» [11]. 
Книга представляет собой серию очерков из жизни заключенных тюрьмы «The King’s Bench Prison» («Королевская скамья», Саутуорк, южный Лондон, Англия). Миншул был помещён в долговую тюрьму, где проводил время за написанием образов заключенных. Автор утверждает, что даже среди такого необычного контингента людей, всегда найдется человек «на все руки мастер»: он же и сутенер, и брокер, и палач.

Now for the moft part your porter is either fome broken cittizen, who hath plaid Jack- of-all-trades, fome pander, broker, or hangman, that hath plaid the knaue with all men, and for the more certainty his embleme is a red beard, to which facke hath made his nofecoufingerman [11, c. 50].

Итак, в зависимости от контекста данная паремия может означать человека, обладающего поверхностными знаниями из разных областей и, по сути, являющегося верхоглядом, дилетантом, «master of none». Так, английский писатель Мартин Клиффорд (Martin Clifford, 1624-1677) неоднократно критиковал «Героические пьесы» английского поэта, драматурга, баснописца XVII века Джона Драйдена (John Dryden, 1631-1700). В «Репетиции» (1671г.) авторы, среди которых был сам Клиффорд, осмеивали ошибки, присущие, на их взгляд, «героической пьесе» Драйдена, рассматривая их с точки зрения «здравого смысла». Средствами пародирования и гротеска они доказывали безрассудность и искусственность «героических пьес»: безмотивность поведения персонажей, напыщенность их монологов, их неуклюжие попытки донести до зрителя необходимую информацию, бессвязность фабулы и подчинение ее конфликту между честью и любовью [12].

B «Mr. Dryden's Poems in Four Letters» Мартин Клиффорд называет поэта «великим плагиатором, живущим в невежестве и темноте, подобно утробе матери» и утверждает, что его произведения не представляют ничего ценного.

And next I will detect your Thefts, letting the World know how great a Plagiary you are; and that for all your pretences to Wit and Judicious Censure, you do live in 
as much Ignorance and Darkness as you did in the Womb: That your Writings are like a Jack of all Trades Shop, they have Variety, but nothing of value [13, c. 4].

То есть в данном случае современная пословица «Jack of all trades, master of none» вполне применима, по мнению Клиффорда, к творчеству Джона Драйдена.

Ещё один неоднозначный английский поэт Джон Кливленд (John Cleveland, 1613-1658) также был известен своими едкими сатирами. У Кливленда нельзя прочитать ни одного стиха без непроизвольной гримасы. Его слова похожи на пилюли, которые надо глотать. Он часто дарит нам столь крепкие орешки, что мы рискуем остаться без зубов, разгрызая их только для того, чтобы обнаружить пустоту [14]. Его первая книга «Характер лондонского дневника» вышла в 1644 году и представляла собой издевательство над своего рода предтечей современных газет, издававшихся в Лондоне и отражавших политические волнения того времени с точки зрения парламентариев. Кливленд часто использует в своих стихах необычные языковые образы, типичные для метафизической поэзии, представителем которой он является. В сборнике стихов и прозы «The Character of a London-Diurnall with Severall Select Poems» (Персонажи лондонского дневного журнала, 1647) он пишет:

The Saints Monopolie, the zealous Cluster,

Which like a Porcupine presents a Muster,

And shoots his quills at Bishops and their Sees,

A devout litter of young Maccabees.

Thus,Jack-of-all-tradeshath devoutly showne,

The twelve Apostles on a Cherry-stone [15].

Дать точный перевод этого куплета не представляется возможным, так как Кливленд в своих стихах использовал катахрезу. Как стилистический приём катахреза представляет собой соединение слов в переносном смысле вопреки несовместимости их буквальных значений. На основе проведенного 
исследования творчества Джона Кливленда, неистощимого на шутки и игривые сарказмы, мы можем только предполагать, что в данном контексте «Jack-of-alltrades» имеет двойной смысл, доступный для понимания только его современникам.

Британский политик Джеймс Бург (James Burgh, 1714-1775) в книге «The Art of Speaking», посвящённой ораторскому искусству, предлагает другой вариант второй части пословицы, цитируя диалог с древнегреческим писателем Лукианом, высмеивающего общественные, религиозные и философские предрассудки, а также другие пороки современного ему общества в своих сатирических сочинениях.

Who are you?

7th Ghost. Sir I am an universal genius.

Merc[ury]. That is to say, in plain English, a Jack of all trades, and good at none [16].

\section{Kmo mbl?}

Сэр, я универсальный гений.

То есть, говоря простылм языком, Мастер на все руки и ни в чем не преуспел.

Рассмотрим ещё одну английскую пословицу «All work and no play makes Jack a dull boy». Так обычно говорится о тех, кто не умеет отдыхать, как следует, с подтекстом, что это плохо сказывается на человеке. Эквивалентами паремии могут служить русские пословицы «Делу - время, потехе - час», «Умей дело делать - умей и позабавиться», «Мешай дело с бездельем, проживешь век с весельем». Оказывается, что мысль, содержащаяся в этой пословице, была впервые высказана тысячи лет назад египетским мудрецом и визирем Птаххотепом (Ptahhotep), который написал в древнеегипетском литературном сочинении «Поучения Птаххотепа» (The Instructions of PtahHotep, 2400 год до н.э.) буквально следующее: 
One that reckons accounts all the day passes not a happy moment. One that gladdens his heart all the day provides not for his house. The bowman hits the mark, as the steersman reaches land, by diversity of aim. He that obeys his heart shall command [17].

Подобные тексты обычно писались старейшинами для того, чтобы научить молодежь, как правильно жить. В наставлениях Птаххотепа рассматриваются различные добродетели, необходимые для хорошей жизни, и то, как жить в соответствии с древнеегипетскими концепциями истины богини Маат, которые были важной частью египетской культуры и олицетворяли равновесие, порядок и гармонию. Таким образом, общий смысл данного отрывка видится в том, что во всём надо соблюдать меру как в работе, так и в празднестве.

Англо-валлийский историк и писатель XVII века Джеймс Хауэлл (James Howell, 1594-1666) включает пословицу «All work and no play makes Jack a dull bоy» в сборник «Paroimiographia. Proverbs, or, old Sayed Sawes\& Adages in English (or the Saxon Toung) Italian, French and Spanish whereunto the British, for their great antiquity and weight are added» (1659) [18]. А некоторые писатели, такие как ирландская эссеист и публицист Мария Эджуорт (Maria Edgeworth, 1768-1849) в дидактическом рассказе для детей «Harry and Lucy Concluded» («Гарри и Люси договорились», 1825), добавляет вторую часть к известной пословице

All work and no play makes Jack a dull boy,

All play and no work makes Jack a mere toy [19, c. 155].

Вообще, имя Джек часто фигурирует в детских стихах и рифмовках, например, в сборнике «Стихи и песенки матушки Гусыни» [20]. (Mother Goose's Nursery Rhymes) [19]. Но историк Линда Алчин (Linda Alchin) в своей книге «The Secret History of Nursery Rhymes» утверждает, что эти, наивные на первый взгляд, стишки связаны с реальными событиями из истории Англии 
(«Ring Around the Rosie» - Эпидемия чумы в 1347-1345 г.г.; Georgie Porgie прототип Георга II, который при наступлении якобитов сбежал из Англии и т.д.). И этот список неоднозначных личностей и значимых событий можно было бы с успехом продолжить. Иными словами получается, что политическая сатира того времени была искусно замаскирована в формулировках детских стишков. Они использовались в качестве средства для пародирования непопулярных политических деятелей, королевских особ и исторических событий. Рифмовки обычно отличались лаконичностью и поэтому легко запоминались, что было решающим фактором в те времена, когда многие люди не умели читать и писать. Так, в XVI веке имя Jack Sprat использовалось по отношению к людям маленького роста, что наводит на мысль об английском монархе династии Стюартов Карле I (Charles I), рост которого составлял 162 см.

Jack Sprat

Could eat no fat,

His wife could eat no lean;

And so,

Betwixt them both,

They licked the platter clean [21].

Джек Уэст

Жирного не ест.

Его жена Джудит

Постного не любит.

Но они вдвоем

Сидят за столом.

И поэтому вилкой

И поэтому ложкой

Cъедают все,

До последней крошки (пер.И.Родина) [22]. 
Король остался «худым» (lean), когда парламент отказал ему в субсидиях для ведения войны на континенте, и со своей королевой Генриеттой-Марией он мог «вылизать блюдо начисто» (They licked the platter clean) после очередного роспуска английского парламента.

В сборнике стишков «Mother Goose's Nursery Rhymes» также упоминается неразлучная парочка Джек и Джилл.

Jack and Jill went up the hill

To fetch the pail of water;

Jack fell down and broke his crown,

And Jill came tumbling after [21].

Идут на горку Джек и Джилл,

Несут в руках ведерки.

Свалился Джек и лоб разбил,

А Джнилл слетела с горки. (Пер. С.Я. Маршака) [23].

Этот стишок ведет свою историю с первой половины XVII века. Jack and Jill - это пара имен, столь же известная в англоязычном мире, как Адам и Ева. Но если Адам и Ева - первые мужчина и женщина, то Джек и Джилл использовались в качестве имени любой молодой пары.

У Шекспира в комедии «Сон в летнюю ночь» (A Midsummer Night's Dream, 1594) находим интересующую нас пословицу «Every Jack has (shall / must have) his Jill» в несколько изменённом варианте, но сродни русскими эквивалентам таким, как «Всякая невеста для своего жениха родится», «У каждого голубка своя горлица», «На каждого Ивана найдется своя Марья».

That every man should take his own,

in your waking shall be shown.

Jack shall have Jill;

Nought shall go ill;

The man shall have his mare again, 
And all shall be well [24].

Всяк сверчок знай свой шесток,

Всякий будь со своею милой,

Всяк ездок - со своей кобылой,

А конеи - всему венеи [25].

Ирландский англоязычный поэт, драматург Уильям Батлер Йейтс (William Butler Yeats, 1865 - 1939) упоминает имена этой пары в стихотворении «To A Young Beauty» в совершенно неожиданном для читателя ракурсе. Поэт не советует красавице общаться с «every Jack and Jill». В данном контексте Джек и Джилл выступают в отрицательной коннотации, означая «общаться с кем попало».

DEAR fellow-artist, why so free

With every sort of company,

With every Jack and Jill?

Choose your companions from the best;

Who draws a bucket with the rest

Soon topples down the hill [26].

Итак, для того чтобы правильно понять смысл пословицы и адекватно употреблять её в речи, необходимо знать её этимологию. Исследуя английские пословицы, включающие в себя имена собственные, можно сделать вывод о том, что каждая национальная культура имеет свои особенности их употребления. Английские пословицы, как правило, рождались в народной среде, где на свет появлялось большое количество простолюдинов Джеков, этим и объясняется появление этого имени собственного в народном фольклоре. Являясь собирательным образом простого парня, имя Джек в полной мере отображает специфичность национально-культурных стереотипов, создающих языковую картину мира. 


\section{Список литературы}

1. Иванова Е.В. Мир в английских и русских пословицах. СПб. Изд-во СПбГУ. 2006, 280 с.

2. Гумбольд В. Фон. Язык и философия культуры. М.: Прогресс, 1985, $448 \mathrm{c}$.

3. Особенности фольклора как средства обучения иностранному языку Линева Е.А., Савельева Е.Б., Котова Е.Г. Перспективы науки. 2018. № 3 (102). C. 124-127.

4. Смулкевич А. «Исповедь влюбленного» Джона Гауэра: единство в разнообразии. [Электронный ресурc]. URL: https://pandia.ru/text/82/089/ 42779.php (дата обращения 20.12.2021)

5. Gower John. Confessio amantis or tales of the seven deadly sins. [Электронный pecypc]. URL: https://www.gutenberg.org/files/266/266-h/266h.htm(дата обращения 15.12.2021)

6. Shakespeare William. The Taming Of The Shrew. [Электронный pecypc].URL: http://lib.ru/SHAKESPEARE/ENGL/taming_en.txt (дата обращения 19.12.2021)

7. Шекспир У. Укрощение строптивой. [Электронный ресурc]. URL: https://thelib.ru/books/shekspir_uilyam/ukroschenie_stroptivoy-read-3.html (дата обращения 19.12.2021)

8. Greene's Groats-Worth of Wit. [Электронный pecypc]. URL: http://www.luminarium.org/renascence-editions/greene1.html (дата обращения 19.12.2021)

9. Шенбаум С. Шекспир. Краткая документальная биография. [Электронный pecypc]. URL: http://svr-lit.ru/svr-lit/shakespeare-schoenbaum/ index.htm (дата обращения 19.12.2021)

10. Пешков И.В. F1, или Книга доказательств: теорема Шекспира как лемма авторства. [Электронный ресурc]. URL: http://www.w-shakespeare.ru/ 
library/f1-ili-kniga-dokazatelstv-teorema-shekspira-kaklemma-avtorstva36.html(дата обращения 23.12.2021)

11. Essayes and characters of a prison and prisoners. [Электронный pecypc]. URL: https://archive.org/details/essayesandchara00minsgoog (дата обращения 21.12.2021)

12. Дж. Драйден в полемике о классическом наследии в Англии. [Электронный pecypc]. URL: https://md-eksperiment.org/post/20171030-dzhdrajden-v-polemike-o-klassicheskom-nasledii-v-anglii (дата обращения 05.12.2021)

13. Clifford M. Notes upon Mr, Drydens Poems in four letters. [Электронный pecypc]. URL: https://quod.lib.umich.edu/e/eebo/A33458.0001.001?rgn=main; view=fulltext (дата обращения 19.12.2021)

14. Красавченко Т.Н. Эволюция понятия «остроумие» в английской поэзии, поэтике и эстетике. [Электронный ресурс]. URL: https://cyberleninka.ru/ article/n/evolyutsiya-ponyatiya-ostroumie-v-angliyskoy-poezii-poetike-i-estetike/ viewer (дата обращения 25.12.2021)

15. The Character of a London-Diurnall with Severall Select Poems. [Электронный ресурс]. URL: https://quod.lib.umich.edu/e/eebo/A33429.0001.001/ 1:3?rgn=div1; view=fulltext (дата обращения 20.12.2021)

16. Burgh James. The Art of Speaking. [Электронный pecypc]. URL: https://archive.org/details/artspeakingbyjb00burggoog (дата обращения 20.12.2021)

17. The Instruction of Ptah-Hotep and the Instruction of Ke'Gemni. The Oldest Books in the World. [Электронный pecypc]. URL: https://www.gutenberg.org/files/ 30508/30508-h/30508-h.htm (дата обращения 08.01.2022)

18. Paroimiographia. Proverbs, or, old Sayed Sawes\& Adages in English (or the Saxon Toung) Italian, French and Spanish whereunto the British, for their great antiquity and weight are added. [Электронный pecypc]. URL: https://quod.lib.umich.edu/e/eebo/A44738.0001.001/1:12?rgn=div1; view=fulltext (дата обращения 07.01.2022) 
19. Edgeworth M. Harry and Lucy concluded: being the last part of Early lessons. [Электронный pecypc]. URL: https://archive.org/stream/ harrylucyconclud02edgerich/harrylucyconclud02edgerich_djvu.txt (дата обращения 07.01.2022)

20. Стихи и песенки матушки Гусыни. [Электронный ресурс]. URL: https://skazkiwsem.ru/Malysham/stihi-matushki-gusyni/index.html (дата обращения 08.01.2022)

21. Mother Goose's Nursery Rhymes. A Collection of Alphabets, Rhymes, Tales, and Jingles. [Электронный pecypc]. URL: https://www.gutenberg.org/ files/39784/39784-h/39784-h.htm (дата обращения 08.01.2022)

22. Из английской детской поэзии. Джек Уэст. [Электронный ресурс]. URL: https://stihi.ru/2006/08/24-919 (дата обращения 08.01.2022)

23. Стихи Маршака. [Электронный ресурc]. URL:https://www.hobobo.ru/ stihi/stihi-marshaka/ (дата обращения 08.01.2022)

24. Shakespeare W. A Midsummer Night's Dream. [Электронный ресурс]. URL: http://lib.ru/SHAKESPEARE/ENGL/dream_en.txt (дата обращения 09.01.2022)

25. Шекспир У. Сон в летнюю ночь. [Электронный ресуpc]. URL: http://www.world-art.ru/lyric/lyric.php?id=6062\&public_page=3 (дата обращения 09.01.2022)

26. Yeats W.B. To a young beauty. [Электронный pecypc]. URL: https://www.sacred-texts.com/neu/yeats/lpy/lpy121.htm (дата обращения 09.01.2022) 


\section{РАЗДЕЛ III.}

\section{ДИССЕМИНАЦИЯ ИННОВАЦИОННОГО ТЕХНОЛОГИЧЕСКОГО ОПЫТА}

УДК 621.316.72(9)

Глава 7.

МЕТОДОЛОГИЯ ФУНКЦИОНАЛЬНЫХ ИСПЫТАНИЙ

УСТРОЙСТВ ЗАЩИТЫ ОТ ОДНОФАЗНЫХ ЗАМЫКАНИЙ НА ЗЕМЛЮ

В ЭЛЕКТРИЧЕСКИХ СЕТЯХ 10 КВ С ПОМОЩЫЮ

COMTRADE-ФАЙЛОВ

Андрианова Людмила Прокопьевна

д-р техн. наук, профессор

Леонтьева Татьяна Анатольевна

доцент

Соколенко Владимир Владимирович

студент

Уфимский государственный нефтяной технический университет

Аннотация: В статье рассмотрена нормативная методология функциональных испытаний устройств защит от однофазных замыканий на землю (О33) в электрических сетях 10 кВ с помощью COMTRADE-файлов. Для моделирования процессов О33 принята конфигурация сети, имеющая несколько радиальных распределительных линий, отходящих от одной из секций шин подстанции. На основе принятой конфигурации проводится математическое моделирование сети с изолированной нейтралью, сети с компенсированной нейтралью с дугогасящим реактором с регулируемой 
индуктивностью, сети с нейтралью, заземленной через низкоомный резистор.

Сформированные Comtrade-файлы испытательных осциллограмм в каждой смоделированной сети преобразуются испытательной установкой Omicron CMC 256 plus в аналоговый сигнал и подводятся к устройствам защиты от О33, работа которых контролируется по контактам его выходных реле.

Ключевые слова: электрическая сеть, сеть с изолированной нейтралью, сеть с компенсированной нейтралью, дугогасящий реактор, низкоомный резистор, однофазное замыкание на землю, устройства защиты, функциональные испытания, испытательная установка, Comtrade-файлы.

\title{
METHODOLOGY OF FUNCTIONAL TESTS OF SINGLE-PHASE EARTH FAULT PROTECTION DEVICES IN 10 KV ELECTRICAL NETWORKS USING COMTRADE FILES
}

\section{Andrianova Lyudmila Prokopevna Leontieva Tatiana Anatolyevna Sokolenko Vladimir Vladimirovich}

\begin{abstract}
The article considers the normative methodology of functional tests of protection devices against single-phase earth faults (OPC) in $10 \mathrm{kV}$ electrical networks using COMTRADE files. A network configuration with several radial distribution lines extending from one of the bus sections of the substation has been adopted to simulate the processes of the OZZ. Based on the accepted configuration, mathematical modeling of a network with an isolated neutral, a network with a compensated neutral with an arc-extinguishing reactor with adjustable inductance, a network with a neutral grounded through a low-resistance resistor is carried out. The generated Comtrade files of test waveforms in each simulated network are converted by the Omicron CMC 256 plus test unit into an analog signal and are connected to the protection devices from the OPC, the operation of which is controlled by the contacts of its output relays.
\end{abstract}


Key words: electrical network, network with isolated neutral, network with compensated neutral, arc-extinguishing reactor, low-resistance resistor, single-phase earth fault, protection devices, functional tests, test installation, Comtrade files.

\section{1. Обобщенный алгоритм проведения испытаний устройств защиты} от однофазных замыканий на землю с помощью COMTRADE-файлов

Объект испытаний - устройство защиты от однофазных замыканий на землю (О33) в сети с изолированной нейтралью и нейтралью, заземляемой через дугогасящий реактор (компенсированной нейтралью).

Цель испытаний - подтверждение соответствий функциональных характеристик аттестуемого устройства защиты (терминала) утвержденным Техническим требованиям ПАО «ФСК ЕЭС» и ПАО «Россети» путем проверки работы устройства при различных видах и характере однофазных замыканий на землю в сети с изолированной и компенсированной нейтралью [2].

В соответствии с обобщенный алгоритм проведения испытаний устройств защиты от О33 с помощью COMTRADE-файлов представляет собой последовательность действий:

1) Перед проведением испытаний на математической модели сети с изолированной и компенсированной нейтралью заданной конфигурации, проводится расчет мгновенных значений токов и напряжений, подводимых к испытуемому устройству, при разных видах однофазных замыканий на землю в характерных точках сети;

2) Расчет мгновенных значений производится на интервале заданной длительности, достаточной для проверки функционирования устройства;

3) Результаты расчета мгновенных значений записываются в файл унифицированного формата Comtrade;

4) Для каждой точки замыкания и для каждого вида замыкания формируется отдельный файл; 
5) Сформированные Comtrade-файлы преобразуются испытательной установкой в аналоговую форму и подводятся к испытуемому устройству;

6) Работа испытуемого устройства контролируется по контактам его выходных реле.

Для проведения испытаний используются испытательная установка Omicron CMC 256 plus c усилителем сигналов Omicron CMS 156 и персональный компьютер с программой, управляющей испытательной установкой [1, с. 187].

Испытательная установка Omicron CMC 256plus представляет собой высокоточный комплект для испытаний реле с шестью каналами тока и высокими амплитудами напряжения для задач, требующих высокой точности. Уникальная точность и функциональная гибкость CMC 256plus делают этот прибор идеальным средством исследования и разработки, производства и типовых испытаний для производителей средств защиты и измерений [3].

Усилители CMA 156 и CM S156 (усилитель с 6 каналами тока + усилитель с 3 каналами напряжения и тока) могут использоваться в сочетании с испытательными комплектами СМС или совместно с цифровыми устройствами моделирования сети энергосистемы, работающими в режиме реального времени [3].

Испытательная установка Omicron CMC 256 plus с усилителем сигналов

Omicron CMS 156 обеспечивает воспроизведение COMTRADE файлов.

\section{2. Моделирование сети 10 кВ с изолированной нейтралью}

Для проведения моделирования принята сеть 10 кВ типичной конфигурации, представленная 5 радиальными распределительными линиями (присоединения $\Phi 1, \Phi 2, \Phi 3, \Phi 4$ и Ф5), отходящими от одной из секций шин подстанции 110/35/10 кВ (рис. 1). Секция получает питание от понизительного трансформатора ТДТ-20000 115,5/38,5/11 кВ. На шинах 10 кВ установлен трансформатор напряжения 3х3НОМ-15 10000: $\sqrt{3} / 100: \sqrt{3} /$ 100:3. Отходящие линии являются кабельными, и со стороны подстанции имеют трансформаторы 
тока нулевой последовательности ТЗЛМ-1 с коэффициентом трансформации 25. Все кабели 10 кВ трехфазные, имеют алюминиевые жилы и оболочку. При моделировании сети с изолированной нейтралью положение разъединителей S1 и S2 - отключенное.

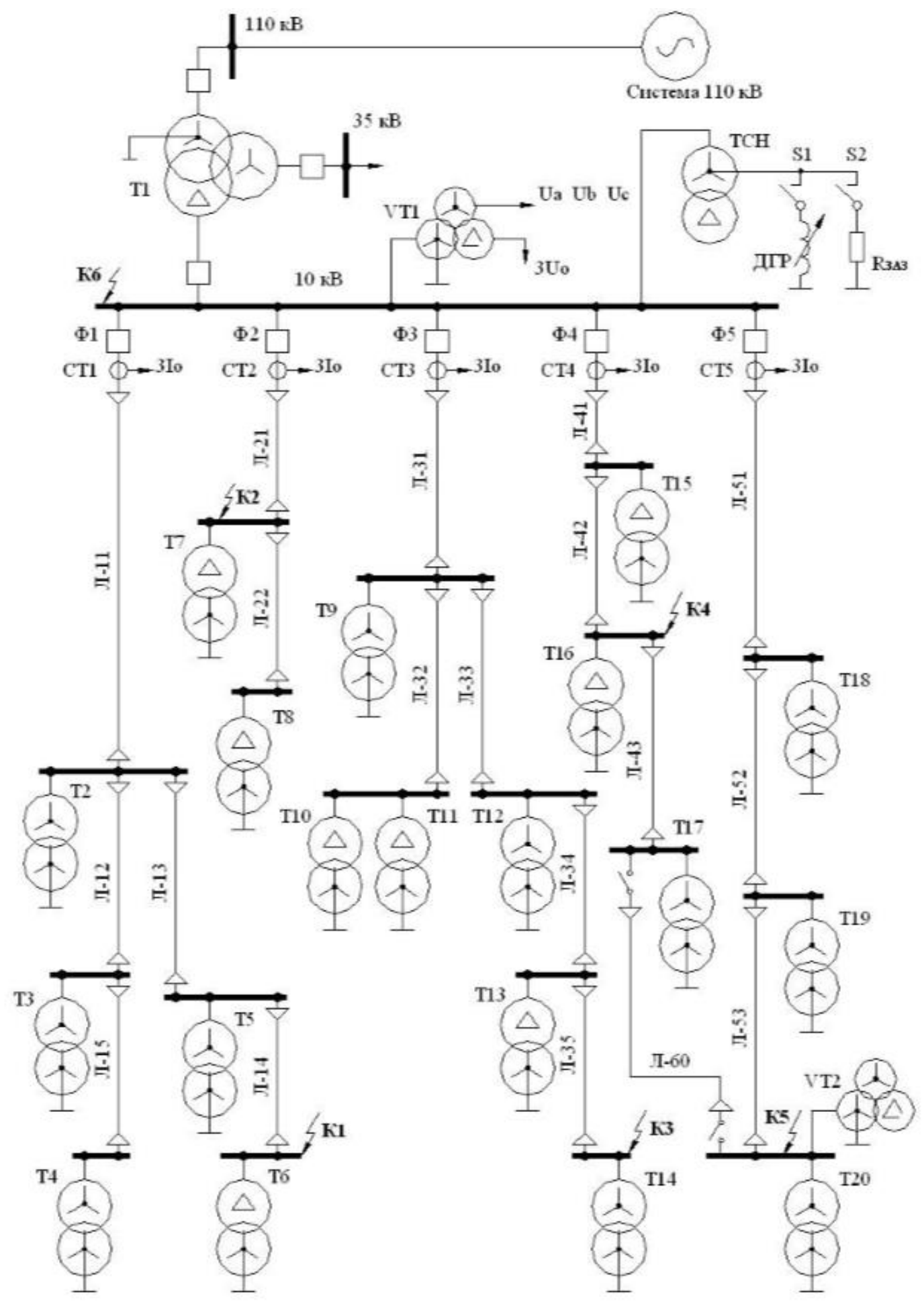

Рис. 1. Конфигурация сети при моделировании О33 [1, с. 189] 
Длины линий, сечение кабелей, емкостный ток при глухих однофазных замыканиях на землю и нагрузочный ток линии приведены в таблице 1.

Таблица 1

Параметры линии при глухих однофазных замыканиях на землю

\begin{tabular}{|c|c|c|c|c|c|}
\hline Присоединение & Линия & $\begin{array}{c}\text { Длина, } \\
\text { км }\end{array}$ & $\begin{array}{c}\text { Сечение жилы кабеля, } \\
\text { мм² }^{2}\end{array}$ & $\begin{array}{l}\text { IC, } \\
\text { A }\end{array}$ & $\begin{array}{c}\text { Нагрузка } \\
\text { присоединения, А }\end{array}$ \\
\hline \multirow{5}{*}{$\Phi 1$} & Л-11 & 3 & 240 & \multirow{5}{*}{9,96} & \multirow{5}{*}{244,5} \\
\hline & Л-12 & 1,5 & 95 & & \\
\hline & Л-13 & 2,3 & 95 & & \\
\hline & Л-14 & 0,8 & 50 & & \\
\hline & Л-15 & 0,5 & 50 & & \\
\hline \multirow[t]{2}{*}{$\Phi 2$} & Л-21 & 0,8 & 150 & \multirow[t]{2}{*}{1,48} & \multirow[t]{2}{*}{58,1} \\
\hline & Л-22 & 0,3 & 95 & & \\
\hline \multirow{5}{*}{ Ф3 } & Л-31 & 0,9 & 150 & \multirow{5}{*}{3,5} & \multirow{5}{*}{191,2} \\
\hline & Л-32 & 0,6 & 95 & & \\
\hline & Л-33 & 0,6 & 95 & & \\
\hline & Л-34 & 0,4 & 50 & & \\
\hline & Л-35 & 0,5 & 50 & & \\
\hline \multirow{3}{*}{$\Phi 4$} & Л-41 & 0,6 & 150 & \multirow{3}{*}{1,77} & \multirow{3}{*}{75} \\
\hline & Л-42 & 0,5 & 95 & & \\
\hline & Л-43 & 0,3 & 95 & & \\
\hline \multirow{3}{*}{$\Phi 5$} & Л-51 & 1,1 & 150 & \multirow{3}{*}{2,55} & \multirow{3}{*}{83,1} \\
\hline & Л-52 & 0,7 & 95 & & \\
\hline & Л-53 & 0,2 & 95 & & \\
\hline \multirow{6}{*}{$\begin{array}{c}\text { Ф5 при отключенной } \\
\text { линии Л41 и } \\
\text { включенной Л-60 }\end{array}$} & Л-51 & 1,1 & 150 & \multirow{6}{*}{4,34} & \multirow{6}{*}{157,2} \\
\hline & Л-52 & 0,7 & 95 & & \\
\hline & Л-53 & 0,2 & 95 & & \\
\hline & Л-60 & 0,8 & 95 & & \\
\hline & Л-42 & 0,5 & 95 & & \\
\hline & Л-43 & 0,3 & 95 & & \\
\hline
\end{tabular}

Суммарный емкостный ток сети при однофазном замыкании на землю 19,26 А. На каждой линии имеются трансформаторные подстанции (ТП) с установленными понижающими трансформаторами $10 / 0,4$ кВ. Типы 173 
трансформаторов, группы соединения обмоток и их нагрузки приведены в таблице 2. В сети имеются два трансформатора напряжения, один из которых (VT1) установлен на шинах питающей подстанции, а другой (VT2) на шинах ТП-53.

При проведении моделирования все силовые трансформаторы и измерительные трансформаторы напряжения вводятся с учетом нелинейности характеристики намагничивания.

Таблица 2

Типы трансформаторов и группы соединения обмоток

\begin{tabular}{|c|c|c|}
\hline Подстанция & Тип трансформатора & Группа соединения обмоток \\
\hline ТП-11 & TM-1600/10(T2) & Y/Yo-0 \\
\hline ТП-12 & TM-1600/10(T3) & Y/Yo-0 \\
\hline ТП-13 & TM-1600/10(T5) & Y/Yo-0 \\
\hline ТП-14 & TM-630/10 (T6) & $\Delta / Y_{0}-11$ \\
\hline ТП-15 & TM-400/10 (T4) & Y/Yo-0 \\
\hline ТП-21 & TM-630/10 (T7) & $\Delta / Y_{0}-11$ \\
\hline ТП-22 & TM-630/10 (T8) & $\Delta / Y_{0}-11$ \\
\hline ТП-31 & TM-1000/10(T9) & Y/Yo-0 \\
\hline ТП-32 & $2 \times \mathrm{TM}-630 / 10(\mathrm{~T} 10, \mathrm{~T} 11)$ & $\Delta / \mathrm{Yo}_{11}$ \\
\hline ТП-33 & TM-1000/10(T12) & Y/Yo-0 \\
\hline ТП-34 & TM-630/10 (T13) & $\Delta / Y_{0}-11$ \\
\hline ТП-35 & TM-400/10 (T14) & Y/Yo-0 \\
\hline ТП-41 & TM-630/10 (T15) & $\Delta /$ Yo-11 \\
\hline ТП-42 & TM-630/10 (T16) & $\Delta /$ Yo-11 \\
\hline ТП-43 & TM-400/10 (T17) & Y/Yo-0 \\
\hline ТП-51 & TM-400/10 (T18) & Y/Yo-0 \\
\hline ТП-52 & TM-1000/10(T19) & Y/Yo-0 \\
\hline ТП-53 & TM-400/10 (T20) & Y/Yo-0 \\
\hline
\end{tabular}

Все силовые трансформаторы, за исключением Т1, имеют переключатели ПБВ, установленные в положение $+2,5 \%$. Трансформаторы ТП на стороне 
0,4 кВ нагружены на 70\% номинальной мощности при $\cos \alpha=0,8$, нагрузка имеет линейную характеристику.

Дополнительно 8 кВт нагрузки по каждому трансформатору представлены как нагрузка нелинейная, осветительная с люминесцентными лампами, что соответствует уровню высших гармоник в сети, близком к минимальному.

Гармонический состав установившегося тока замыкания на землю при глухом однофазном замыкании на шинах питающей подстанции (действующее значение в процентах от суммарного тока) по результатам моделирования составляет:

\begin{tabular}{|c|c|}
\hline 50 Гц & $99,91 \%$ \\
\hline 250 Гц & $2,84 \%$, \\
\hline 350 Г & $2,42 \%$ \\
\hline 550 Г & $1,67 \%$, \\
\hline 650 Гц & $0,74 \%$ \\
\hline 850 Гц & $0,3 \%$ \\
\hline
\end{tabular}

Точки сети, в которых происходят моделируемые однофазные замыкания на землю, обозначены на схеме сети (см. рис. 1) как К1 - К6.

Все О33 принимаются как самоликвидирующиеся через 0,6 секунды после возникновения.

При дуговых О33 напряжение зажигания дуги принято 6000 В амплитудных во всех случаях. Гашение дуги по теории Петерсена (при прохождении высокочастотной составляющей тока замыкания через нулевое значение) или по теории Петерса и Слепяна (при прохождении составляющей 50 Гц тока замыкания через нулевое значение). 
Тангенс дельта изоляции кабелей распределительных линий 10 кВ принят $2 \%$.

Для сети принятой конфигурации (см. рис. 1) проведено математическое моделирование и сформированы Comtrade-файлы испытательных осциллограмм (Таблица 3). Для возможности одновременной проверки пяти терминалов защиты, а также терминалов, реализующих групповой принцип действия, каждый Comtrade-файл несет информацию по 9 каналам:

- 5 каналов тока нулевой последовательности по числу фидеров Ф1-Ф5,

- 3 канала фазных напряжений $\mathrm{U}_{\mathrm{A}}, \mathrm{U}_{\mathrm{B}}, \mathrm{U}_{\mathrm{C}}$

- 1 канал напряжения нулевой последовательности $3 \mathrm{U}_{0}$. Частота дискретизации - 10000 Гц.

Длительность процесса - 1100...1400 мс, из которых 100...200 мс режим, предшествующий замыканию.

Расположение каналов в каждом файле следующее:

\begin{tabular}{|l|l|l|l|}
\hline \multicolumn{2}{|c|}{$\begin{array}{c}\text { Каналы тока нулевой } \\
\text { последовательности }\end{array}$} & \multicolumn{2}{|c|}{ Каналы напряжений } \\
\hline 1 & Ток СТ1 (вторичный) & 6 & $\begin{array}{l}\text { Напряжение 3Шо (вторичное } \\
\text { с дополнительной обмотки ТН }\end{array}$ \\
\hline 2 & Ток СТ2 (вторичный) & 7 & $\begin{array}{l}\text { Напряжение фазы А (вторичное } \\
\text { с основной обмотки ТН) }\end{array}$ \\
\hline 3 & Ток СТ3 (вторичный) & 8 & $\begin{array}{l}\text { Напряжение фазы В (вторичное } \\
\text { с основной обмотки ТН) }\end{array}$ \\
\hline 4 & Ток СТ4 (вторичный) & 9 & $\begin{array}{l}\text { Напряжение фазы С (вторичное } \\
\text { с основной обмотки ТН) }\end{array}$ \\
\hline 5 & Ток СТ5 (вторичный) & & \\
\hline
\end{tabular}


Таблица 3

Перечень испытательных Comtrade-файлов для сети с изолированной нейтралью, их условные номера и ожидаемое действие испытуемой функции защиты ( «+» срабатывает, «-» не срабатывает)

\begin{tabular}{|c|c|c|c|c|c|c|c|}
\hline \multirow{2}{*}{$\begin{array}{l}\text { № } \\
\text { п.п. }\end{array}$} & \multirow[t]{2}{*}{ № файла } & \multirow[t]{2}{*}{ Вид и место О33 } & \multicolumn{5}{|c|}{$\begin{array}{c}\text { Ожидаемое действие функции } \\
\text { защиты по фидерам }\end{array}$} \\
\hline & & & $\Phi 1$ & $\Phi 2$ & $\Phi 3$ & $\Phi 4$ & $\Phi 5$ \\
\hline 1 & DC1_1_01 & Глухое О33 на фазе А в ТП-14, точка К1 & + & - & - & - & - \\
\hline 2 & DC1_1_02 & $\begin{array}{l}\text { Дуговое О33 на фазе А в ТП-14, точка К1, с } \\
\text { гашением дуги по Петерсену }\end{array}$ & + & - & - & - & - \\
\hline 3 & DC1_1_03 & $\begin{array}{l}\text { Дуговое О3З на фазе А в ТП-14, точка К1, с } \\
\text { гашением дуги по Петерсу и Слепяну }\end{array}$ & + & - & - & - & - \\
\hline 4 & DC1_1_04 & $\begin{array}{l}\text { Дуговое О33 на фазе А в ТП-14, точка К1, с } \\
\text { гашением дуги по Петерсу и Слепяну, Л-41 } \\
\text { отключена, Л-60 включена. Напряжение } \\
\text { зажигания дуги изменяется в процессе О33 }\end{array}$ & + & - & - & - & - \\
\hline 5 & DC1_1_05 & $\begin{array}{l}\text { Дуговое ОЗ3 на фазе А в ТП-14, точка К1, с } \\
\text { гашением дуги по Петерсу и Слепяну, Л-41 } \\
\text { отключена, Л- } 60 \text { включена. Напряжение } \\
\text { зажигания дуги изменяется в процессе О33, с } \\
\text { возникновением пауз }\end{array}$ & + & - & - & - & - \\
\hline 6 & DC1_1_06 & $\begin{array}{l}\text { Дуговое ОЗ3 на фазе А в ТП-14, точка К1, с } \\
\text { гашением дуги по Петерсу и Слепяну. } \\
\text { Напряжение зажигания дуги изменяется в } \\
\text { процессе О33 }\end{array}$ & + & - & - & - & - \\
\hline 7 & $\begin{array}{l}\text { DC1_1_07 } \\
\text { DC1_1_36 }\end{array}$ & $\begin{array}{l}\text { Дуговое О3З на фазе А в ТП-14, точка К1, с } \\
\text { гашением дуги по Петерсу и Слепяну. } \\
\text { Напряжение зажигания дуги изменяется в } \\
\text { процессе ОЗ3, с возникновением пауз }\end{array}$ & + & - & - & - & - \\
\hline 8 & DC1_1_08 & $\begin{array}{l}\text { Дуговое О3З на фазе А в ТП-14, точка К1, с } \\
\text { гашением дуги по Петерсу и Слепяну. } \\
\text { Напряжение зажигания дуги } 600 \text { В ампл. }\end{array}$ & + & - & - & - & - \\
\hline 9 & DC2_1_01 & Глухое ОЗ3 на фазе А в ТП-21, точка К2 & - & + & - & - & - \\
\hline 10 & DC2_1_02 & $\begin{array}{l}\text { Дуговое О3З на фазе А в ТП-21, точка К2, с } \\
\text { гашением дуги по Петерсену }\end{array}$ & - & + & - & - & - \\
\hline 11 & DC2_1_03 & $\begin{array}{l}\text { Дуговое ОЗЗ на фазе А в ТП-21, точка К2, с } \\
\text { гашением дуги по Петерсу и Слепяну }\end{array}$ & - & + & - & - & - \\
\hline
\end{tabular}




\section{Продолжение Таблицы 3}

\begin{tabular}{|c|c|c|c|c|c|c|c|}
\hline 12 & DC2_1_04 & $\begin{array}{l}\text { Глухое О3З на фазе А в ТП-21, точка К2, Л-41 } \\
\text { отключена, Л-60 включена }\end{array}$ & - & + & - & - & \\
\hline 13 & DC2_1_05 & $\begin{array}{l}\text { Дуговое ОЗ3 на фазе А в ТП-21, точка К2, с } \\
\text { гашением дуги по Петерсену, Л-41 отключена, } \\
\text { Л60 включена } \\
\text { не }\end{array}$ & - & + & - & - & - \\
\hline 14 & DC2_1_06 & $\begin{array}{l}\text { Дуговое О33 на фазе А в ТП-21, точка К2, с } \\
\text { гашением дуги по Петерсу и Слепяну, Л- } 41 \\
\text { отключена, Л- } 60 \text { включена } \\
\text { не }\end{array}$ & - & + & - & - & - \\
\hline 15 & DC2_1_07 & $\begin{array}{l}\text { Дуговое О33 на фазе А в ТП-21, точка К2, с } \\
\text { гашением дуги по Петерсу и Слепяну. } \\
\text { Напряжение зажигания дуги изменяется в } \\
\text { процессе О33 }\end{array}$ & - & + & - & - & - \\
\hline 16 & DC2_1_08 & $\begin{array}{l}\text { Дуговое О33 на фазе А в ТП-21, точка К2, с } \\
\text { гашением дуги по Петерсу и Слепяну. } \\
\text { Напряжение зажигания дуги изменяется в } \\
\text { процессе О33 с возникновением пауз }\end{array}$ & - & + & - & - & - \\
\hline 17 & DC2_1_09 & $\begin{array}{l}\text { Дуговое О3З на фазе А в ТП-21, точка К2, с } \\
\text { гашением дуги по Петерсу и Слепяну. } \\
\text { Напряжение зажигания дуги } 600 \text { В ампл }\end{array}$ & - & + & - & - & - \\
\hline 18 & DC3_1_01 & Глухое О3З на фазе А в ТП-35, точка К3 & - & - & + & - & - \\
\hline 19 & DC3_1_02 & $\begin{array}{l}\text { Дуговое О3З на фазе А в ТП-35, точка К3, с } \\
\text { гашением дуги по Петерсену }\end{array}$ & - & - & + & - & - \\
\hline 20 & DC3_1_03 & $\begin{array}{l}\text { Дуговое О3З на фазе А в ТП-35, точка К3, с } \\
\text { гашением дуги по Петерсу и Слепяну }\end{array}$ & - & - & + & - & - \\
\hline 21 & DC1_1_36 & $\begin{array}{l}\text { Дуговое ОЗ3 на фазе А в ТП-35, точка К3, с } \\
\text { гашением дуги по Петерсу и Слепяну. } \\
\text { Напряжение зажигания дуги изменяется в } \\
\text { процессе ОЗ3 с возникновением пауз }\end{array}$ & - & - & + & - & - \\
\hline 22 & DC4_1_01 & Глухое О3З на фазе А в ТП-42, точка К4 & - & - & - & + & - \\
\hline 23 & DC4_1_02 & $\begin{array}{l}\text { Дуговое О3З на фазе А в ТП-42, точка К4, с } \\
\text { гашением дуги по Петерсену }\end{array}$ & - & - & - & + & - \\
\hline 24 & DC4_1_03 & $\begin{array}{l}\text { Дуговое О3З на фазе А в ТП-42, точка К4, с } \\
\text { гашением дуги по Петерсу и Слепяну }\end{array}$ & - & - & - & + & - \\
\hline 25 & DC5_1_01 & Глухое О3З на фазе А в ТП-53, точка К5 & - & - & - & - & + \\
\hline
\end{tabular}




\section{Продолжение Таблицы 3}

\begin{tabular}{|c|c|c|c|c|c|c|c|}
\hline 26 & DC5_1_02 & $\begin{array}{l}\text { Дуговое О3З на фазе А в ТП-53, точка К5, с } \\
\text { гашением дуги по Петерсену }\end{array}$ & - & - & - & - & + \\
\hline 27 & DC5_1_03 & $\begin{array}{l}\text { Дуговое О33 на фазе А в ТП-53, точка К5, с } \\
\text { гашением дуги по Петерсу и Слепяну }\end{array}$ & - & - & - & - & + \\
\hline 28 & DC6_1_01 & $\begin{array}{l}\text { Глухое О3З на фазе А шин } 10 \text { кВ подстанции, } \\
\text { точка К6 }\end{array}$ & - & - & - & - & - \\
\hline 29 & DC6_1_02 & $\begin{array}{l}\text { Дуговое О3З на фазе А шин } 10 \text { кВ подстанции, } \\
\text { точка К6, с гашением дуги по Петерсену. }\end{array}$ & - & - & - & - & - \\
\hline 30 & DC6_1_03 & $\begin{array}{l}\text { Дуговое О3З на фазе А шин } 10 \text { кВ подстанции, } \\
\text { точка К6, с гашением дуги по Петерсу и Слепяну }\end{array}$ & - & - & - & - & - \\
\hline 31 & DC0_0_01 & $\begin{array}{l}\text { Включение фидера } 1 \text { под напряжение. О33 } \\
\text { отсутствует. Разновременность включения фаз } \\
\text { выключателя } 40 \text { мс (вкл. ф. А - } 20 \text { мс - вкл. ф. В } \\
\text { - } 20 \text { мс - вкл. ф.С) }\end{array}$ & - & - & - & - & - \\
\hline 32 & DC13_2_1 & $\begin{array}{l}\text { Дуговое ОЗ3 на ф. В в ТП-14 (фидер 1), точка К1, } \\
\text { с напряжением зажигания дуги } 3000 \text { В. Переход в } \\
\text { двойное замыкание на землю со второй точкой на } \\
\text { ф. А в ТП-35 (фидер 3). Перегорание } \\
\text { предохранителя на ф. В в ТП-14 с сохранением } \\
\text { дугового О33 в ТП-35 с изменяющимся } \\
\text { напряжением зажигания дуги }\end{array}$ & 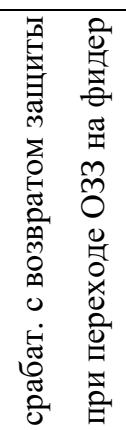 & - & 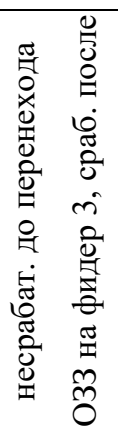 & - & - \\
\hline 33 & DC13_2_2 & $\begin{array}{l}\text { Дуговое О3З на ф. В в ТП-14 (фидер 1), точка К1, } \\
\text { с напряжением зажигания дуги } 8000 \text { В. Переход в } \\
\text { двойное замыкание на землю со второй точкой на } \\
\text { ф. А в ТП-35 (фидер 3). Перегорание } \\
\text { предохранителя на ф. А в ТП-35 с сохранением } \\
\text { дугового ОЗ3 на ф. В в ТП-14 }\end{array}$ & + & - & $\begin{array}{c}\text { Неср. } \\
\text { при } \\
\text { О33 }\end{array}$ & - & - \\
\hline 34 & DD1_1_40 & $\begin{array}{l}\text { Кратковременное (2 мс) О33 на ф. А в ТП-14 } \\
\text { (фидер 1), точка К1. }\end{array}$ & - & - & - & - & - \\
\hline 35 & DD1_1_41 & $\begin{array}{l}\text { Кратковременное (14 мс) О33 на ф. А в ТП-14 } \\
\text { (фидер 1), точка К1 }\end{array}$ & - & - & - & - & - \\
\hline 36 & DC1_1_09 & Глухое ОЗ3 на фазе А в ТП-14, точка К1 & + & - & - & - & - \\
\hline 37 & DC2_1_10 & Глухое ОЗ3 на фазе А в ТП-21, точка К2 & - & + & - & - & - \\
\hline 38 & DC3_1_04 & Глухое ОЗ3 на фазе А в ТП-35, точка К3 & - & - & - & + & - \\
\hline 39 & DC5_1_04 & Глухое ОЗ3 на фазе А в ТП-53, точка К5 & - & - & - & - & + \\
\hline 40 & DC6_1_04 & $\begin{array}{l}\text { Глухое ОЗ3 на фазе А шин } 10 \text { кВ подстанции, } \\
\text { точка К6. }\end{array}$ & - & - & - & - & - \\
\hline
\end{tabular}


Пояснения к таблице 3. В опытах, имеющих несколько файлов в графе «№ файла», файл данных при проведении испытаний выбирается произвольно.

Опыты 34 и 35 выполняются при введенной выдержке времени 100 мс и более. Для функций защиты, реагирующих на переходный процесс и (или) на высшие гармонические составляющие токов, проводятся дополнительные испытания в режимах, имеющих наименее интенсивный переходный процесс при возникновении О33 (замыкание при прохождении мгновенным напряжением поврежденной фазы нулевого значения - $\alpha_{\text {Кз }}=0$ ).

\section{3. Моделирование сети 10 кВ с компенсированной нейтралью}

В схему сети 10 кВ с компенсированной нейтралью в нейтраль трансформатора собственных нужд (ТСН) включен дугогасительный реактор (ДГР) с регулируемой индуктивностью (см. рис. 1). При моделировании положение разъединителя S1 - включенное, разъединителя S2 - отключенное.

Схема замещения ДГР содержит индуктивность и два резистора, один из которых включен параллельно индуктивности и эквивалентирует потери в стали магнитопровода, а другой соединен последовательно с индуктивностью и эквивалентирует потери в меди обмотки. Потери в стали и потери в меди условно приняты одинаковыми. Тангенс угла потерь для всего ДГР (P / Q) принят равным 0,02 .

При выборе значения индуктивности ДГР при настройке компенсации дополнительно учитывалось индуктивное сопротивление рассеяния ТСH.

Настройка компенсации $\left.\mathrm{v}=\left(\mathrm{I}_{\mathrm{C}}-\mathrm{I}_{\text {Комп }}\right) / \mathrm{I}_{\mathrm{C}}\right)$, принятая для пяти режимов:

\begin{tabular}{|l|c|}
\hline Точная & $\mathrm{v}=0$ \\
\hline Перекомпенсация 10\% & $\mathrm{v}=-0,1$ \\
\hline Недокомпенсация $10 \%$ & $\mathrm{v}=+0,1$ \\
\hline Перекомпенсация 20\% & $\mathrm{v}=-0,2$ \\
\hline Недокомпенсация 20\% & $\mathrm{v}=+0,2$ \\
\hline
\end{tabular}

180 
Гармонический состав установившегося тока замыкания на землю при глухом однофазном замыкании на шинах питающей подстанции и точной настройке компенсации (действующее значение) по результатам моделирования:

\begin{tabular}{|c|c|}
\hline Гармоника & Значение тока \\
\hline 50 Гц & 0,861 А (активный) \\
\hline 250 Гц & $0,506 \mathrm{~A}$ \\
\hline 350 Гц & $0,373 \mathrm{~A}$ \\
\hline 550 Гц & 0,626 \\
\hline 650 Гц & $0,226 \mathrm{~A}$ \\
\hline
\end{tabular}

Для сети принятой конфигурации проведено математическое моделирование и сформированы Comtrade-файлы испытательных осциллограмм (Таблица 4). Параметры Comtrade-файлов в отношении числа каналов, частоты дискретизации, длительности процесса, длительности предшествующего режима и расположения каналов в файле полностью идентичны соответствующим параметрам файлов для сети с изолированной нейтралью.

Таблица 4

Перечень испытательных Comtrade-файлов для сети с компенсированной нейтралью, их условные номера и ожидаемое действие испытуемой функции защиты ( «+» срабатывает, «-» не срабатывает)

\begin{tabular}{|c|c|c|c|c|c|c|c|}
\hline \multirow{2}{*}{$\begin{array}{l}\text { № } \\
\text { П.П. }\end{array}$} & \multirow[t]{2}{*}{ № файла } & \multirow[t]{2}{*}{ Вид и место ОЗ3 } & \multicolumn{5}{|c|}{$\begin{array}{c}\text { Ожидаемое действие функции } \\
\text { защиты по фидерам }\end{array}$} \\
\hline & & & $\Phi 1$ & $\Phi 2$ & $\Phi 3$ & $\Phi 4$ & $\Phi 5$ \\
\hline 1 & DD1_1_01 & $\begin{array}{l}\text { Глухое О33 на фазе А в ТП-14, точка К1. } \\
\text { Настройка компенсации точная }(\mathrm{v}=0) .\end{array}$ & + & - & - & - & - \\
\hline 2 & DD1_1_02 & $\begin{array}{l}\text { Дуговое О33 на фазе А в ТП-14, точка К1. } \\
\text { Настройка компенсации точная ( } \mathrm{v}=0) .\end{array}$ & + & - & - & - & - \\
\hline 3 & $\begin{array}{l}\text { DD1_1_22 } \\
\text { DD1_1_32 }\end{array}$ & $\begin{array}{l}\text { Дуговое О33 на фазе А в ТП-14, точка К1 с } \\
\text { изменяющемся напряжением зажигания дуги. } \\
\text { Настройка компенсации точная (v =0). } \\
\text { ср }\end{array}$ & + & - & - & - & - \\
\hline
\end{tabular}




\section{Продолжение Таблицы 4}

\begin{tabular}{|c|c|c|c|c|c|c|c|}
\hline 4 & DD1_1_03 & $\begin{array}{l}\text { Глухое ОЗ3 на фазе А в ТП-14, точка К1. } \\
\text { Перекомпенсация } 20 \%(\mathrm{v}=-0,2) \text {. }\end{array}$ & + & - & - & - & - \\
\hline 5 & DD1_1_04 & $\begin{array}{l}\text { Дуговое ОЗЗ на фазе А в ТП-14, точка К1. } \\
\text { Перекомпенсация } 20 \%(\mathrm{v}=-0,2) .\end{array}$ & + & - & - & - & - \\
\hline 6 & $\begin{array}{l}\text { DD1_1_24 } \\
\text { DD1_1_34 }\end{array}$ & $\begin{array}{l}\text { Дуговое О33 на фазе А в ТП-14, точка К1с } \\
\text { изменяющемся напряжением зажигания дуги. } \\
\text { Перекомпенсация } 20 \%(\mathrm{v}=-0,2) .\end{array}$ & + & - & - & - & - \\
\hline 7 & DD1_1_05 & $\begin{array}{l}\text { Глухое ОЗ3 на фазе А в ТП-14, точка К1. } \\
\text { Недокомпенсация } 20 \%(\mathrm{v}=0,2) .\end{array}$ & + & - & - & - & - \\
\hline 8 & DD1_1_06 & $\begin{array}{l}\text { Дуговое О3З на фазе А в ТП-14, точка К1. } \\
\text { Недокомпенсация } 20 \%(\mathrm{v}=0,2) .\end{array}$ & + & - & - & - & - \\
\hline 9 & $\begin{array}{l}\text { DD1_1_26 } \\
\text { DD1_1_36 }\end{array}$ & $\begin{array}{l}\text { Дуговое ОЗ3 на фазе А в ТП-14, точка К1с } \\
\text { изменяющемся напряжением зажигания дуги. } \\
\text { Недокомпенсация } 20 \%(\mathrm{v}=0,2) .\end{array}$ & + & - & - & - & - \\
\hline 10 & DD1_1_07 & $\begin{array}{l}\text { Глухое ОЗ3 на фазе А в ТП-14, точка К1. } \\
\text { Перекомпенсация } 10 \%(\mathrm{v}=-0,1) .\end{array}$ & + & - & - & - & - \\
\hline 11 & DD1_1_08 & $\begin{array}{l}\text { Дуговое ОЗЗ на фазе А в ТП-14, точка К1. } \\
\text { Перекомпенсация } 10 \%(\mathrm{v}=-0,1) .\end{array}$ & + & - & - & - & - \\
\hline 12 & DD1_1_09 & $\begin{array}{l}\text { Глухое ОЗ3 на фазе А в ТП-14, точка К1. } \\
\text { Недокомпенсация } 10 \%(\mathrm{v}=0,1) .\end{array}$ & + & - & - & - & - \\
\hline 13 & DD1_1_10 & $\begin{array}{l}\text { Дуговое О3З на фазе А в ТП-14, точка К1. } \\
\text { Недокомпенсация } 10 \%(\mathrm{v}=0,1) .\end{array}$ & + & - & - & - & - \\
\hline 14 & DD2_1_01 & $\begin{array}{l}\text { Глухое О3З на фазе А в ТП-21, точка К2. } \\
\text { Настройка компенсации точная (v =0). }\end{array}$ & - & + & - & - & - \\
\hline 15 & DD2_1_02 & $\begin{array}{l}\text { Дуговое ОЗ3 на фазе А в ТП-21, точка К2. } \\
\text { Настройка компенсации точная }(\mathrm{v}=0) \text {. }\end{array}$ & - & + & - & - & - \\
\hline 16 & DD2_1_03 & $\begin{array}{l}\text { Глухое О3З на фазе А в ТП-21, точка К2. } \\
\text { Перекомпенсация } 20 \%(\mathrm{v}=-0,2) .\end{array}$ & - & + & - & - & - \\
\hline 17 & DD2_1_04 & $\begin{array}{l}\text { Дуговое О3З на фазе А в ТП-21, точка К2. } \\
\text { Перекомпенсация } 20 \%(\mathrm{v}=-0,2) .\end{array}$ & - & + & - & - & - \\
\hline 18 & DD2_1_05 & $\begin{array}{l}\text { Глухое ОЗ3 на фазе А в ТП-21, точка К2. } \\
\text { Недокомпенсация } 20 \%(\mathrm{v}=0,2) .\end{array}$ & - & + & - & - & - \\
\hline 19 & DD2_1_06 & $\begin{array}{l}\text { Дуговое ОЗ3 на фазе А в ТП-21, точка К2. } \\
\text { Недокомпенсация } 20 \%(\mathrm{v}=0,2) .\end{array}$ & - & + & - & - & - \\
\hline 20 & DD2_1_07 & $\begin{array}{l}\text { Глухое ОЗ3 на фазе А в ТП-21, точка К2. } \\
\text { Перекомпенсация } 10 \%(\mathrm{v}=-0,1) \text {. }\end{array}$ & - & + & - & - & - \\
\hline 21 & DD2_1_08 & $\begin{array}{l}\text { Дуговое О3З на фазе А в ТП-21, точка К2. } \\
\text { Перекомпенсация } 10 \%(\mathrm{v}=-0,1) .\end{array}$ & - & + & - & - & - \\
\hline 22 & DD2_1_09 & $\begin{array}{l}\text { Глухое ОЗ3 на фазе А в ТП-21, точка К2. } \\
\text { Недокомпенсация } 10 \%(\mathrm{v}=0,1) .\end{array}$ & - & + & - & - & - \\
\hline 23 & DD2_1_10 & $\begin{array}{l}\text { Дуговое О3З на фазе А в ТП-21, точка К2. } \\
\text { Недокомпенсация } 10 \%(\mathrm{v}=0,1) .\end{array}$ & - & + & - & - & - \\
\hline 24 & DD3_1_01 & $\begin{array}{l}\text { Глухое О3З на фазе А в ТП-35, точка К3. } \\
\text { Недокомпенсация } 20 \%(\mathrm{v}=0,2) .\end{array}$ & - & - & + & - & - \\
\hline
\end{tabular}




\section{Продолжение Таблицы 4}

\begin{tabular}{|c|c|c|c|c|c|c|c|}
\hline 25 & $\begin{array}{l}\text { DD3_1_02 } \\
\text { DD3_1_32 } \\
\text { DD3_1_34 } \\
\text { DD3_1_36 }\end{array}$ & $\begin{array}{l}\text { Дуговое О33 на фазе А в ТП- } 35 \text {, точка К3, с } \\
\text { изменяющимся напряжением зажигания дуги. } \\
\text { Недокомпенсация } 20 \%(\mathrm{v}=0,2) .\end{array}$ & - & - & + & - & - \\
\hline 26 & DD4_1_0 & $\begin{array}{l}\text { Глухое О3З на фазе А в ТП-42, точка К4. } \\
\text { Недокомпенсация } 20 \%(\mathrm{v}=0,2) .\end{array}$ & - & - & - & + & - \\
\hline 27 & DD4_1_02 & $\begin{array}{l}\text { Дуговое О33 на фазе А в ТП- } 42 \text {, точка К4, с } \\
\text { изменяющимся напряжением зажигания дуги. } \\
\text { Недокомпенсация } 20 \%(\mathrm{v}=0,2) .\end{array}$ & - & - & - & + & - \\
\hline 28 & DD5_1_01 & $\begin{array}{l}\text { Глухое ОЗЗ на фазе А в ТП-53, точка К5. } \\
\text { Недокомпенсация } 20 \%(\mathrm{v}=0,2) .\end{array}$ & - & - & - & - & + \\
\hline 29 & DD5_1_02 & $\begin{array}{l}\text { Дуговое О33 на фазе А в ТП-53, точка К5, с } \\
\text { изменяющимся напряжением зажигания дуги. } \\
\text { Недокомпенсация } 20 \%(\mathrm{v}=0,2) .\end{array}$ & - & - & - & - & + \\
\hline 30 & DD6_1_01 & $\begin{array}{l}\text { Глухое ОЗ3 на фазе А шин } 10 \text { кВ подстанции, } \\
\text { точка К6. Настройка компенсации точная (v } \\
=0) \text {. }\end{array}$ & - & - & - & - & - \\
\hline 31 & DD6_1_02 & $\begin{array}{l}\text { Дуговое О33 на фазе А шин } 10 \text { кВ подстанции, } \\
\text { точка К6. Настройка компенсации точная (v } \\
=0) \text {. }\end{array}$ & - & - & - & - & - \\
\hline 32 & DD6_1_03 & $\begin{array}{l}\text { Глухое ОЗ3 на фазе А шин } 10 \text { кВ подстанции, } \\
\text { точка К6. } \\
\text { Перекомпенсация } 20 \%(\mathrm{v}=-0,2) \text {. }\end{array}$ & - & - & - & - & - \\
\hline 33 & DD6_1_04 & $\begin{array}{l}\text { Дуговое ОЗ3 на фазе А шин } 10 \text { кВ подстанции, } \\
\text { точка К6. } \\
\text { Перекомпенсация } 20 \%(\mathrm{v}=-0,2) \text {. }\end{array}$ & & & & & \\
\hline 34 & DD6_1_05 & $\begin{array}{l}\text { Глухое ОЗЗ на фазе А шин } 10 \text { кВ, точка К6. } \\
\text { Недокомпенсация } 20 \%(\mathrm{v}=0,2) .\end{array}$ & - & - & - & - & - \\
\hline 35 & DD6_1_06 & $\begin{array}{l}\text { Дуговое О3З на фазе А шин } 10 \text { кВ подстанции, } \\
\text { точка К6. } \\
\text { Недокомпенсация } 20 \%(\mathrm{v}=0,2) \text {. }\end{array}$ & - & - & - & - & - \\
\hline 36 & DD6_1_07 & $\begin{array}{l}\text { Глухое ОЗЗ на фазе А шин } 10 \text { кВ подстанции, } \\
\text { точка К6. } \\
\text { Перекомпенсация } 10 \%(\mathrm{v}=-0,1) \text {. }\end{array}$ & - & - & - & - & - \\
\hline 37 & DD6_1_08 & $\begin{array}{l}\text { Дуговое О33 на фазе А шин } 10 \text { кВ подстанции, } \\
\text { точка К6. } \\
\text { Перекомпенсация } 10 \%(\mathrm{v}=-0,1) \text {. }\end{array}$ & - & - & - & - & - \\
\hline 38 & DD6_1_09 & $\begin{array}{l}\text { Глухое ОЗ3 на фазе А шин } 10 \text { кВ подстанции, } \\
\text { точка К6. } \\
\text { Недокомпенсация } 10 \%(\mathrm{v}=0,1) \text {. }\end{array}$ & - & - & - & - & - \\
\hline 39 & DD6_1_10 & $\begin{array}{l}\text { Дуговое О3З на фазе А шин } 10 \text { кВ подстанции, } \\
\text { точка К6. } \\
\text { Недокомпенсация } 10 \%(\mathrm{v}=0,1) \text {. }\end{array}$ & - & - & - & - & - \\
\hline
\end{tabular}




\section{Продолжение Таблицы 4}

\begin{tabular}{|c|c|c|c|c|c|c|c|}
\hline 40 & DD0_0_01 & $\begin{array}{l}\text { Включение фидера } 1 \text { под напряжение. О33 } \\
\text { отсутствует. Разновременность включения фаз } \\
\text { выключателя } 40 \text { мс. } \\
\text { Настройка компенсации точная (v =0). }\end{array}$ & & - & - & - & - \\
\hline 41 & DD0_0_02 & $\begin{array}{l}\text { Включение фидера } 1 \text { под напряжение. ОЗ3 } \\
\text { отсутствует. Разновременность включения фаз } \\
\text { выключателя } 40 \text { мс. } \\
\text { Перекомпенсация } 20 \%(\mathrm{v}=-0,2) .\end{array}$ & - & - & - & - & - \\
\hline 42 & DD0_0_03 & $\begin{array}{l}\text { Включение фидера } 1 \text { под напряжение. ОЗ3 } \\
\text { отсутствует. Разновременность включения фаз } \\
\text { выключателя } 40 \text { мс. } \\
\text { Недокомпенсация } 20 \%(\mathrm{v}=0,2) \text {. }\end{array}$ & - & - & - & - & - \\
\hline 43 & DD13_2_1 & $\begin{array}{l}\text { Дуговое О33 на ф. В в ТП-14 (фидер 1), точка } \\
\text { К1, с напряжением зажигания дуги } 1000 \text { В. } \\
\text { Переход в двойное замыкание на землю со } \\
\text { второй точкой на ф. А в ТП-35 (фидер 3). } \\
\text { Перегорание предохранителя на ф. В в ТП-14 с } \\
\text { сохранением дугового О33 в ТП-35 с } \\
\text { изменяющимся напряжением зажигания дуги. } \\
\text { Точная настройка компенсации (v = 0). }\end{array}$ & \multirow[t]{2}{*}{ 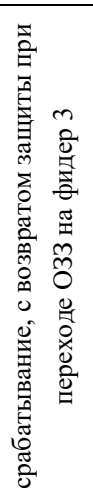 } & \multirow[t]{2}{*}{ - } & \multirow[t]{2}{*}{ 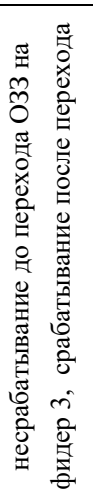 } & \multirow[t]{2}{*}{-} & \multirow[t]{2}{*}{-} \\
\hline 44 & DD13_2_2 & $\begin{array}{l}\text { Условия аналогичные п. } 43, \text { но напряжение } \\
\text { зажигания дуги в ТП-14 3000 В. }\end{array}$ & & & & & \\
\hline 45 & DD13_2_3 & $\begin{array}{l}\text { Дуговое О33 на ф. В в ТП-14 (фидер 1), точка } \\
\text { К1, с напряжением зажигания дуги } 3000 \text { В. } \\
\text { Переход в двойное замыкание на землю со } \\
\text { второй точкой на ф. А в ТП-35 (фидер 3). } \\
\text { Перегорание предохранителя на ф. А в ТП-35 с } \\
\text { сохранением дугового О33 в ТП-14 с } \\
\text { напряжением зажигания дуги } 3000 \text { В. Точная } \\
\text { настройка компенсации (v = 0). }\end{array}$ & 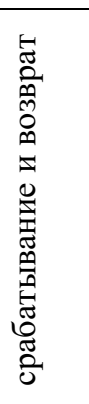 & - & 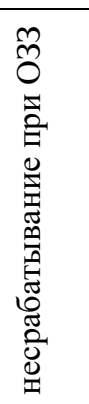 & - & - \\
\hline 46 & DD1_1_40 & $\begin{array}{l}\text { Кратковременное (2 мс) О33 на ф. А в ТП-14 } \\
\text { (фидер } 1) \text {, точка К1 (v =0). }\end{array}$ & - & - & - & - & - \\
\hline 47 & DD1_1_41 & $\begin{array}{l}\text { Кратковременное (70 мс) О3З на ф. А } \\
\text { в ТП-14 (фидер 1), точка К1 (v = 0). }\end{array}$ & - & - & - & - & - \\
\hline 48 & DD3_1_40 & $\begin{array}{l}\text { Кратковременное (2 мс) О33 на ф. А } \\
\text { в ТП-35 (фидер 3), точка К3 (v = 0). }\end{array}$ & - & - & - & - & - \\
\hline 49 & DD3_1_41 & $\begin{array}{l}\text { Кратковременное (70 мс) О33 на ф. А } \\
\text { в ТП-35 (фидер 3), точка К3 (v = 0). }\end{array}$ & - & - & - & - & - \\
\hline 50 & DD1_1_11 & Глухое О33 на фазе А в ТП-14, точка К1 & + & - & - & - & - \\
\hline 51 & DD2_1_11 & Глухое ОЗ3 на фазе А в ТП-21, точка К2 & - & + & - & - & - \\
\hline 52 & DD3_1_11 & Глухое ОЗ3 на фазе А в ТП-35, точка К3. & - & - & + & - & - \\
\hline 54 & DD4_1_11 & Глухое ОЗ3 на фазе А в ТП-42, точка К4 & - & - & - & + & - \\
\hline 55 & DD5_1_11 & Глухое О33 на фазе А в ТП-53, точка К5 & - & - & - & - & + \\
\hline 56 & DD6_1_11 & $\begin{array}{l}\text { Глухое О3З на фазе А шин } 10 \text { кВ подстанции, } \\
\text { точка К6 }\end{array}$ & - & - & - & - & - \\
\hline
\end{tabular}


Пояснения к таблице 4. В опытах, имеющих несколько файлов в графе «№ файла», файл данных при проведении испытаний выбирается произвольно. Опыты 46 - 49 выполняются при введенной выдержке времени 100 мс и более.

Для функций защиты, реагирующих на переходный процесс и (или) на высшие гармонические составляющие токов, проводятся дополнительные испытания в режимах, имеющих наименее интенсивный переходный процесс при возникновении ОЗ3 (замыкание при прохождении мгновенным напряжением поврежденной фазы нулевого значения - $\alpha_{\kappa 3}=0$ ). Настройка компенсации точная $(\mathrm{v}=0)$.

\section{4. Моделирование сети с нейтралью, заземленной через низкоомный}

\section{резистор}

В схему сети 10 кВ с нейтралью, заземленной через низкоомный резистор, в нейтраль трансформатора собственных нужд ТСН включен резистор R3A3 сопротивлением 100 Ом.

При моделировании положение разъединителя S1 - отключенное, разъединителя S2 - включенное. При моделировании процессов при ОЗ3 предполагается, что резистор R3A3 термически стоек при протекании тока в режиме О33 в течение 1 секунды и его активное сопротивление при этом не меняется. Значение тока в месте ОЗ3 при глухом замыкании одной фазы на землю на шинах 10 кВ - 60,4 А.

Также предполагается, что при дуговых ОЗЗ протекание тока в месте замыкания не сопровождается погасанием дуги на интервале в период промышленной частоты (дуга горит непрерывно) и сопротивлением дуги по сравнению с сопротивлением заземляющего резистора можно пренебречь, при этом О3З может рассматриваться как глухое.

Для сети указанной выше конфигурации проведено математическое моделирование и сформированы Comtrade-файлы испытательных осциллограмм (Таблица 5). 
Таблица 5

Перечень испытательных Comtrade-файлов для сети с нейтралью, заземленной через низкоомный резистор, их условные номера и ожидаемое действие испытуемой функции защиты («+» срабатывание; «-» несрабатывание)

\begin{tabular}{|c|c|c|c|c|c|c|c|}
\hline \multirow{2}{*}{$\begin{array}{l}\text { № } \\
\text { П.П. }\end{array}$} & \multirow[t]{2}{*}{ № файла } & \multirow[t]{2}{*}{ Вид и место О33 } & \multicolumn{5}{|c|}{$\begin{array}{c}\text { Ожидаемое действие } \\
\text { функции защиты по фидерам }\end{array}$} \\
\hline & & & $\Phi 1$ & $\Phi 2$ & $\Phi 3$ & $\Phi 4$ & $\Phi 5$ \\
\hline 1 & DF1_1_01 & Глухое О33 на фазе А в ТП-14, точка К1 & + & - & - & - & - \\
\hline 2 & DF2_1_01 & Глухое О33 на фазе А в ТП-21, точка К2 & - & + & - & - & - \\
\hline 3 & DF3_1_01 & Глухое О3З на фазе А в ТП-35, точка К3 & - & - & + & - & - \\
\hline 4 & DF4_1_01 & Глухое О3З на фазе А в ТП-42, точка К4 & - & - & - & + & - \\
\hline 5 & DF5_1_01 & Глухое О3З на фазе А в ТП-53, точка К5 & - & - & - & - & + \\
\hline 6 & DF6_1_01 & $\begin{array}{l}\text { Глухое ОЗ3 на фазе А шин } 10 \text { кВ подстанции, точка } \\
\text { К6 }\end{array}$ & - & - & - & - & - \\
\hline 7 & DF1_1_02 & Глухое О33 на фазе А в ТП-14, точка К1 & + & - & - & - & - \\
\hline 8 & DF2_1_02 & Глухое О33 на фазе А в ТП-21, точка К2 & - & + & - & - & - \\
\hline 9 & DF3_1_02 & Глухое О3З на фазе А в ТП-35, точка К3 & - & - & + & - & - \\
\hline 10 & DF4_1_02 & Глухое О3З на фазе А в ТП-42, точка К4 & - & - & - & + & - \\
\hline 11 & DF5_1_02 & Глухое О3З на фазе А в ТП-53, точка К5 & - & - & - & - & + \\
\hline 12 & DF6_1_02 & $\begin{array}{l}\text { Глухое О33 на фазе А шин } 10 \text { кВ подстанции, точка } \\
\text { К6 }\end{array}$ & - & - & - & - & - \\
\hline
\end{tabular}

Параметры Comtrade-файлов в отношении числа каналов, частоты дискретизации, длительности процесса, длительности предшествующего режима и расположения каналов в файле полностью идентичны соответствующим параметрам файлов для сети с изолированной нейтралью.

Для функций защиты, реагирующих на переходный процесс и (или) на высшие гармонические составляющие токов, проводятся дополнительные испытания в режимах, имеющих наименее интенсивный переходный процесс при возникновении О33 (замыкание при прохождении мгновенным напряжением поврежденной фазы нулевого значения - $\alpha_{\kappa 3}=0$ ). 


\section{СТРАТЕГИЯ НАУЧНО-ТЕХНОЛОГИЧЕСКОГО РАЗВИТИЯ РОССИИ: ПРОБЛЕМЫ И ПЕРСПЕКТИВЫ РЕАЛИЗАЦИИ}

\section{5. Алгоритм функциональных испытаний устройств защиты от О33}

Функциональные испытания устройств при ОЗ3 в сети с изолированной нейтралью, в сети с компенсированной нейтралью и в сети с нейтралью заземленной через резистор проводятся в одинаковой последовательности:

1) Перед проведением испытаний для сети принятой конфигурации рассчитываются и выставляются уставки испытуемой функции защиты. Расчет уставок производится предприятием-изготовителем испытуемого терминала на основании конфигурации и параметров сети, указанных выше. Выставление уставок на испытуемом терминале производится представителем предприятияизготовителя. Значения выставляемых уставок вносятся в протокол испытаний. При необходимости изменения уставок, выявленной в процессе испытаний, в протокол испытаний наряду с исходными, вносятся новые значения, с обоснованием проведенного изменения. После изменения уставок в процессе испытаний, все проделанные ранее опыты повторяются. Рекомендуемая выдержка времени на срабатывание, для отстройки от самоликвидирующихся кратковременных О33 - 100...150 мс;

2) Испытательная установка по выходам конфигурируется в соответствии с порядком расположения каналов в Comtrade-файлах и числом входных цепей конкретного испытуемого устройства;

3) Испытуемое устройство по цепям тока и напряжения подключается к выходам испытательной установки. Допускается одновременное испытание нескольких устройств защиты от О33, подключенных на токи нулевой последовательности разных линий;

4) Выходные цепи испытуемого устройства (контакты выходных реле) подключаются к испытательной установке по еe дискретным входам. Для индивидуального устройства защиты (контролирует только одно присоединение) используется одно выходное реле, для группового устройства защиты (алгоритм защиты предусматривает одновременный контроль 
нескольких присоединений с выбором поврежденного) используются 5 выходных реле, по каждому контролируемому присоединению. Если один терминал содержит защиты от О33 нескольких присоединений, но их алгоритмы не предусматривают между собой взаимодействия, то такой терминал рассматривается как набор устройств индивидуальной защиты;

5) От испытательной установки в соответствии с загруженными осциллограммами на испытуемое устройство подаются токи и напряжения, определяемые заданным видом повреждения в сети. Испытания проводятся последовательно для всех видов повреждения. Для индивидуального устройства защиты в его входные цепи подается ток нулевой последовательности одного (контролируемого) присоединения, для группового устройства защиты - подаются соответствующие токи пяти присоединений;

6) Работа защит от ОЗ3 при каждом виде повреждения контролируется по выходным цепям испытуемого устройства. Допускается проводить анализ работы устройства по осциллограммам, записываемым самим испытуемым устройством;

7) Если испытуемое устройство является групповым, то для всех видов O33, на которые устройство реагирует по принципу действия, оно должно правильно определять поврежденную линию (фидера Ф1..Ф5) и не срабатывать при повреждениях на шинах 10 кВ питающей подстанции;

8) Если испытуемое устройство является индивидуальным (контролирует только одно присоединение), то для всех видов О33, на которые устройство реагирует по принципу действия, оно должно срабатывать при повреждении на линии (фидере), на которой оно включено, и не срабатывать при повреждении на соседних присоединениях или шинах 10 кВ питающей подстанции. Пусковые органы испытуемого устройства защиты должны возвращаться после прекращения O33; 
9) В режимах с двойными замыканиями на землю допускается несрабатывание защиты от О33 на поврежденном фидере в течение двойного замыкания;

10) Результаты испытаний заносятся в протокол.

\section{Заключение}

Методология проведения функциональных испытаний устройств защиты от однофазных замыканий на землю в электрической сети 10 кВ с применением COMTRADE-файлов, позволяет получить достоверные результаты испытаний в сетях с изолированной и компенсированной нейтралью при любом виде повреждения, как для групповых, так и индивидуальных устройств защиты от O33.

Информативный материал, представленный в статье, может быть полезен техническим специалистам: персоналу служб РЗА, АСУ, специалистам в области SCADA-систем и телемеханики, диспетчерам дежурных центров управления режимами электростанций, энергоустановок и сетей в рамках дополнительной профессиональной подготовки и повышения квалификации, а также магистрантам при проведении научных исследований в области релейной защиты компонентов энергосистем.

\section{Список литературы}

1. Технические требования к микропроцессорным устройствам РЗА : Стандарт организации СТО 56947007- 29.120.70.241-2017; введ. 28.02.2017; изм. 11.12.2019. - ПАО «ФСК ЕЭС», 2017. - 357 с. -С.232-251

2. Аттестационные требования к устройствам противоаварийной автоматики (ПА) : Стандарт организации СТО 56947007- 33.040.20.123-2012. Введ. 24.05.2012. - ОАО «ФСК ЕЭС», 2012. -71 с. 
3. Каталог продукции OMIKRON $\|$ НПП ЭКРА. Решения для испытания систем защиты и измерения. Обзор испытательных комплектов: [Электронный pecypc] // сайт https://ekra.nt-rt.ru/images/showcase/CM-Line-Catalog-RUS.pdf; режим доступа 06.01.2022, свободный.

(C) Л.П. Андрианова, Т.А. Леонтьева, В.В. Соколенко, 2021 
УДК 624.04

\title{
Глава 8.
}

МЕТОДИКИ ОПРЕДЕЛЕНИЯ НЕСУЩЕЙ СПОСОБНОСТИ

ОДИНОЧНОЙ СВАИ И ЕЕ РАЗДЕЛЕНИЕ НА СОПРОТИВЛЕНИЕ

ГРУНТА ПОД ОСТРИЕМ И ПО БОКОВОЙ ПОВЕРХНОСТИ

\author{
Сирожиддинов Зайниддин \\ доктор технических наук, профессор \\ Самаркандский государственный \\ архитектурно-строительный институт
}

Аннотация: В данном исследовании предлагается методика вероятности - статистической обработки результатов испытаний свай пробной статической нагрузкой, а также уточненный метод определения несущей способности свай по результатом испытания, при котором учитывались основные процессы статической нагрузки. Также в работе приводится (для практического расчета) разработанный метод разделения несущей способности сопротивления под острием и по боковой поверхности свай. Предложенные в работе методы расчета несущей способности в конечном этапе позволяют оценить уровень надежности свайных фундаментов.

Ключевые слова: свая, острие, несущая способность, испытания, дисперсионный анализ, надежность.

\author{
METHODS FOR DETERMINING THE CARRYING CAPACITY \\ OF A SINGLE PIL AND ITS SEPARATION INTO THE RESISTANCE \\ OF THE SOIL UNDER THE POINT AND ON THE SIDE SURFACE
}

Sirojiddinov Zayniddin 
Abstract: A method of probability is proposed - statistical processing of the results of tests of piles with a test static load, a refined method for determining the bearing capacity of piles by the test result is also proposed, which takes into account the main processes that pass during the test of piles with a static load. Also present (for practical calculation) the developed method for dividing the bearing capacity into resistances under the tip and along the lateral surface of the piles. The methods for calculating the bearing capacity proposed in the work at the final stage make it possible to assess the level of reliability of pile foundations.

Key words: Pile, tip, bearing capacity, tests, analysis of variance, reliability.

\section{Введение}

Основным методом определения критериев несущей способности одиночной сваи являются ее испытания пробной статической нагрузкой. Даже в табличном методе расчета коэффициенты $f_{i}$ и $R_{i}$ устанавливаются на основе статистической обработки большого числа статических испытаний одиночных свай. Такой же методический подход принят и в настоящей работе, то есть в качестве основных данных для анализа рассматриваются результаты статических испытаний одиночных свай различного сечения и длины в разнообразных инженерно-геологических условиях.

Со времен А.А. Луга, впервые выполневщего обобщение результатов I200 испытаний для определения $f_{i}$ и $R_{i}[1]$, различными организациями во многих регионах бывшего СССР были проведены многие тысячи подобных испытаний. Поскольку точность статистического анализа многопараметрического явления существенно зависит от представительности выборки, нами была предпринята попытка изучить накопленный к настоящему времени разрозненный материал этих испытаний и составить банк данных для последующего анализа. Решение этой задачи осуществлялось поэтапно: 
- на I этапе производился сбор материалов о результатах испытаний свай пробной статической нагрузкой по отчетным, диссертационным и опубликованным материалам, методика которого изложена в 1 разделе,

- на II этапе проводилась начальная (первичная) обработка результатов испытаний свай, заключающаяся в определении ее несущей способности, методика которой изложена в разделе 2; разделение несущей способности свай на сопротивление грунта под острием - $R$ и по боковой поверхности - $f$, по методике изложенной в разделе 3; наконец, группировка и дисперсионный анализ величин $R$ и $f$ с целью выявления различных факторов на них, изложенных в разделе 4;

- на III этапе проводилась окончательная вероятностно-статистическая обработка величин $R$ и $f$.

В результате этой обработки установлены нормативные и расчетные значения $R$ и $f$, а также статистические параметры их изменчивости используемые при оценке расчетной несущей способности и уровни надежности свайных фундаментов.

\section{1. Результаты испытаний свай пробной статической нагрузкой.}

Опытной основой статистического исследования является наблюдение. При этом необходимо принимать все меры к тому, чтобы условия, в которых протекают наблюдения, оставались неизменными от наблюдения к наблюдению. В силу целого ряда причин, главным образом от того, что для несущей способности свай по результатам их испытаний невозможно полностью учесть большого числа разнообразных влияющих факторов, следует ожидать, что результаты наблюдений не будут одинаковыми; от наблюдения к наблюдению они будут испытывать неправильные колебания. 


\section{СТРАТЕГИЯ НАУЧНО-ТЕХНОЛОГИЧЕСКОГО РАЗВИТИЯ РОССИИ: ПРОБЛЕМЫ И ПЕРСПЕКТИВЫ РЕАЛИЗАЦИИ}

Но в этих неправильностях все же может быть замечена особого рода закономерность, которая носит название статистической устойчивости и доказывается теоремой Бернулли: при достаточно большом числе наблюдений можно с практически полной уверенностью ожидать, что частность события будет как угодно мало отличаться от его вероятности [2]. Однако при употреблении таблицы и номограммы достаточно больших чисел является существенно необходимым чтобы наблюдения производилось в обстановке, отвечающей условиям правильного применения методов статистического исчисления.

Переходя к рассмотрению этих условий, необходимо выяснить единицы наблюдения для результатов испытаний свай и тех признаков (факторов), которые отмечаются при наблюдении.

Единицей наблюдения называется тот предмет или явление, относительно которого собираются данные при наблюдении [3]. При разных постановках задач научного исследования оказываются различными и единицы наблюдения.

Для установления статистической устойчивости (выявления закономерности) по результатам испытаний свай пробной статической нагрузкой в качестве единицы наблюдения, несущая ее способность не дает желаемых результатов. Из-за большого числа влияющих факторов (признаков) практически невозможно обеспечить, чтобы несущая способность свай по результатам массовых испытаний была бы однородной.

Для того, чтобы единицы наблюдений были однородными, необходимо чтобы они обладали значительным числом общих признаков. Этому соответствуют удельное сопротивление грунтов под острием свай $(R)$ и по боковой поверхности $(f)$ устанавливаемые по результатам их испытаний.

Кроме единицы наблюдения необходимо, приступая к наблюдению, определить те свойства, явления или признаки, сведения о которых должны 
быть собраны при наблюдении. Признаки, отмечаемые при наблюдении, можно разделить на два вида: во-первых, общие признаки, отметка которых производится только с целью установления однородности изучаемых единиц наблюдения - это вид грунта, в котором проведено испытание свай; во-вторых, основные признаки, отметка которых составляет главную цепь наблюдения это размеры поперечного сечения сваи, глубина ее погружения ( для $R$ ), средняя глубина расположения слоя грунта (для $f$ ) и физико-механические характеристики грунтов для обоих величин $R$ и $f$.

Следует особо отметить, что достижение полной однородности единиц наблюдения является неосуществимым не только для величин $R$ и $f$, но и любого другого производственного процесса, как бы далеко мы ни продвинулись в этом отношении, всегда мы встречаемся с элементами неоднородности [3]. Более того, благодаря, именно, наличию элементов неоднородности, приводящему к изменчивости свойств изучаемого явления, появляется самый предмет статистического исчисления - случайные величины. Признаки, которые характеризуются элементами неоднородности, являются основными признаками, представляющими примеры случайных величин.

Ввиду крайнего многообразия признаков (влияющих на $R$ и $f$ ), каждый из которых представляет интерес в том или ином отношении, но отметка (учет) которых была бы очень трудна из-за их многочисленности, приходится при наблюдении ограничиваться только немногими признаками, наиболее существенно влияющими на величины $R$ и $f$. При исследовании часто бывает достаточным остановиться одновременно на двух, трех, редко четырех основных признаках.

Одновременное изучение большого числа основных признаков оказывается не только довольно сложным, но и не достигающим цели, так как 
разного рода статистические характеристики, вполне ясные и имеющие реальное значение при одновременном изучении немногих признаков, утрачивают ясность и смысл при числе признаков более трех [3].

Признаки, отмечаемые при наблюдении (с целью обеспечения однородности) могут быть качественными и количественными.

Качественные признаки не поддаются измерению, тогда как количественные могут быть выражены при помощи чисел, а точность и достоверность конечных результатов наблюдений $R$ и $f$ зависят как от качественных, так и от количественных признаков (влияющих на них факторов). При сборе материалов испытаний свай для обеспечения однородности величин $R$ и $f$, особое внимание уделялось следующим основным факторам: соответствию методики испытания каждой сваи определенным (единым) требованиям (ГОСТа, СН и Па СП); полнота информации о режиме испытания, грунтовых условиях, параметрах сваи, способы их погружения. С этой целью при сборе материалов к результатам испытаний свай были предъявлены следующие основные требования:

I. Отобраны результаты испытаний забивных свай пробной статической нагрузкой, проведенных в пылевато-глинистых и песчаных грунтах. Исключены из рассмотрения результаты испытаний проведенных в вечномерзлых, просадочных, засоленных, набухающих и других особых видах грунтах.

При встрече торфяных прослоек толщиной менее 1 м, согласно исследованию проведенным Ф.К. Лапшиным [4] их трение не учитывалось, при толщине более 1 м, эти результаты испытания исключены из рассмотрения. Не принималось также в расчет и трение в верхних свеженасыпных слоях грунта. 


\section{СТРАТЕГИЯ НАУЧНО-ТЕХНОЛОГИЧЕСКОГО РАЗВИТИЯ РОССИИ: ПРОБЛЕМЫ И ПЕРСПЕКТИВЫ РЕАЛИЗАЦИИ}

2. Включены в обработку забивные сваи квадратные, прямоугольные, круглые сплошного сечения и полые с закрытым нижним концом, с наружным диаметром (или стороной поперечного сечения) от 25 до 40 см, длиной от 3 до 20 м, погруженные механическими (подвесными), паровоздушными и дизельными молотами. Исключены из рассмотрения сваи погруженные в предварительно пробуренные скважины (лидеры), с использованием подмыва, а также сваи, опущенные с помощью вибропогружателей всех типов.

3. Были отобраны те материалы, у которых величина нагрузки при испытании доведена до исчерпания несущей способности свай (до предельной нагрузки), но вызывающей их осадку не менее 16-20 мм. Отсутствие единой критерии несущей способности свай и предельной нагрузки на нее отразились и на результатах испытаний свай. В зависимости от того, согласно каким нормативным документам придерживались изыскатели при проведении испытаний, конечные нагрузки, согласно архивным материалам, доведены до величины вызывающей осадки от 3-4 мм до 80 мм и более. Согласно ГОСТ 5686-78, испытания свай, главным образом, проводится в двух стадиях: I - в комплексе проектно- изыскательских работ; II - при строительстве (фундаментов), Если для I стадии одним из главных целей является определение несущей способности свай, то для II-й стадии - контроль соответствия их несущей способности расчетным нагрузкам, предусмотренным в проекте свайного фундамента. В последнем случае, вследствие принятия большого, недостаточно обоснованного коэффициента запаса, используемого для определения расчетной нагрузки, как правило, нагрузка на сваи не доводится до исчерпания ее несущей способности.

4. С целью исключения влияния времени "отдыха" на несущую способность свай отобраны те результаты испытаний, у которых, согласно ГОСТ, были выдержаны сроки "отдыха" Однако регламентированные по ГОСТу сроки "отдыха" следует считать минимальными, поскольку засасывание 
свай происходит более длительное время в зависимости от вида, состава, свойств и состояния прорезаемых грунтов и грунтов под нижним концом свай [4.5.6]. Однако на практике, ввиду различных производственных причин, реальная продолжительность "отдыха" оказывается в очень широких пределах: от нескольких суток (в основном в I стадии) до нескольких месяцев (II стадия), влияние которого на конечный результат практически невозможно установить и остается лишь отнести к элементам неоднородности результатов испытаний.

5. Для исключения взаимовлияния были отобраны те результаты, у которых расстояние в осях от испытываемой сваи до анкерной, или до ближайшей опоры грузовой платформы согласно ГОСТ составили не менее 5 наибольших размеров поперечного сечения сваи. Анализ материалов испытаний показывает, что данное требование часто нарушается во II-ой стадии (при строительстве), когда в качестве анкерных свай используются соседние сваи ленточного фундамента или куста.

6. В качестве факторов, вызывающих изменчивость случайных величин $R \quad$ и $f$, следовательно, и несущей способности свай, на основании имеющихся исследований [1.5.6 и др.], в первую очередь, можно принять: размеры поперечного сечения сваи, глубина ее погружения (для $R$ ), средняя глубина расположения слоя грунта (для $f$ ), число пластичности, показатель текучести пылевато-глинистых грунтов, крупность песчаных грунтов, a также коэффициент пористости (плотность), степень влажности, удельное сцепление, угол внутреннего трения и модуль общей деформации для обоих видов грунта.

Однако СП 50-102-2003, а также предшествующие этому СП нормативные документы, допускают для предварительных расчетов, а также для окончательных расчетов оснований зданий и сооружений II и III классов, определять нормативные и расчетные значения прочностных и деформационных характеристик грунтов по их физическим характеристикам. 
По-видимому, частично по этой причине, а также из-за того, что обоснованная методика расчета несущей способности, использующая прочностные и деформационные характеристики, практически отсутствует, в более чем 50\% материалах испытаний свай либо эти характеристики грунтов отсутствуют, либо определены с применением различных приборов и методик. Более того, из-за отсутствия в соответствующих нормативных документах более жестких требований, а также, поскольку в методах расчета непосредственно не используется значение $J_{\rho}$ очень часто, вместо количественного значения $J_{\rho}$ приводятся наименование пылевато-глинистых грунтов по числу пластичности.

Изложенные обстоятельства снижают ценность имеющихся результатов стандартных испытаний свай для их статистической обработки и вынуждает ориентироваться, главным образом, на физические характеристики грунтов. Исключение лишь составляют специальные испытания, в том числе комплексные, проведенные для научно-исследовательских целей, которые отличаются как качеством проведенных испытаний, так и полнотой информации.

После того как были установлены единица наблюдения и признаки, отмеченные при наблюдении, остается решить вопрос какое число единиц частичной совокупности (опытных значений $R$ или $f$ ) достаточно велико для того, чтобы по ней можно было делать надежные выводы или, из каких именно единиц надо составить частичную совокупность ( $R$ или $f$ ), чтобы можно было рассматривать ее в качестве представительного образца.

Ответ на этот вопрос может быть найден при помощи так называемой номограммы достаточно больших чисел [3].

Номограмма достаточно больших чисел показывает как достаточно большое число наблюдений, объем частичной совокупности, зависит от "степени уверенности", величины допустимой ошибки и самой неизвестной 
доли, а также от "меры изменчивости". Но зависимость от неизвестной доли удается исключить, выбрав для нее наихудшее значение.

"Степень уверенности" или "мера риска" определяется величиной вероятности, с которой делается соответствующее заключение.

Относительно выбора величины вероятности Р нет какого-либо общего решения, одинакового при всех исследованиях. "Теория может только предлагать те или другие меры риска, но она не может установить какую степень риска должно признавать допустимой [3]. Чем ближе к единице будет величина рассматриваемой вероятности, тем надежней будет заключение. В практике научных исследований обычно принимается $P=0,95$ [3].

Допустимая ошибка при исследованиях устанавливается в зависимости от природы изучаемого явления. В большинстве случаев она принимается равной $0,05[3]$.

Эти же рекомендации, т.е. $P=0,95$ и $\varepsilon=0,05$ приняты в настоящей работе при исследовании закономерности изменения случайных величин $R_{i}$ и $f_{i}$.

Что же касается "меры изменчивости" или коэффициентов вариации $V_{R}$ и $V_{f}$, величин $R$ и $f$, необходимых для определения числа наблюдений, практически отсутствуют какие-либо рекомендации. Дело в том, что результаты наблюдений $R$ или $f$, всегда будут несколько отличаться от их "истинных значений", рассеиваться, сосредоточиваться около них. Возникает вопрос, каков должен быть объем частичной совокупности (величин $R$ или $f$ ), чтобы с той или иной "степенью уверенности" можно было бы считать, что отклонение от единицы отношения среднего арифметического наблюдаемых значений ( $R$ или $f)$ к их истинному значению не превышает допустимой ошибки. 


\section{СТРАТЕГИЯ НАУЧНО-ТЕХНОЛОГИЧЕСКОГО РАЗВИТИЯ РОССИИ: ПРОБЛЕМЫ И ПЕРСПЕКТИВЫ РЕАЛИЗАЦИИ}

Решение данного вопроса осуществлено следующим образом. В начале, для определения минимального числа наблюдений коэффициенты вариации (мера изменчивости) $V_{R}$ и $V_{f}$ приняты на основании имеющихся исследований. После того, как было обеспечено минимальное число наблюдений, определены фактические значения $V_{R}$ и $V_{f}$, которые использованы при определении расчетных значений $R$ и $f$. Так, например, максимальное значение коэффициента вариации сопротивления сдвигу природных пылевато-глинистых грунтов, согласно исследованиям приведенных в работах [7.8] составляет 25-30\%. При определении же рационального объема статических испытаний для проектирования свайных фундаментов авторы работы [9] рекомендуют коэффициент вариации несущей способности свай принимать: $30 \%$ для песчаных грунтов; 10-20\% для глинистых грунтов.

Следует ожидать, что значения $R$ и $f$ будут более однородными, чем несущая способность свай, следовательно, коэффициенты вариации $V_{R}$ и $V_{f}$, уменьшатся. Если же ориентироваться на максимальные значения $V_{R}$ и $V_{f}$, принимая их равными коэффициенту вариации несущей способности свай, то обеспечивается более надежное число наблюдений. Так, если в среднем принимать $V_{R}=V_{f}=25 \%$, то при $\varepsilon=0,05$ и $P=0,95$ по номограмме [3] находим достаточно большое число равное 98, т.е. этим числом обеспечивается представительность опытных наблюдений для построения разного рода статистических закономерностей и заключений по отношению $R$ или $f$.

Обратим внимание на то, что, не уменьшая степени надежности заключений и не увеличивая допустимой ошибки, при малых эначениях коэффициента вариации случайных величин $R$ и $f$, можно свести достаточно большое число наблюдений до нескольких единиц. Благоларя этому открывается широкое поле для применения методов статистического 201 
исчисления с целью обобщения результатов дорогостоящих и трудоемких испытаний натурных свай пробной статической нагрузкой.

Известно, что столь широкий диапазон изменения параметров (свойств) грунтов, размеры свай, оказывающие влияния на несущую способность свай, следовательно, и на величины $R$ и $f$ не позволяют по результатам испытаний заранее планировать необходимое число наблюдений. По этой причине сбор материалов испытаний и их первичная обработка - определение несущей способности свай по методике приведенной в разделе 2 и ее разделение на $R$ и $f$, методика которого приведена в разделе 3 , производились до тех пор, пока не было обеспечено необходимое число однородных значений $R$ и $f$, в достаточно широком диапазоне изменения глубины погружения свай, свойств песчаных и глинистых грунтов. При этом, в различных изыскательских организациях материалы испытаний свай, отвечающие вышепредьявляемым требованиям для обеспечения однородности величин $R$ и $f$, составили разные доли от просмотренных.

Например, в Санкт-Петербургском ПКТИ всего были просмотрены более 15000 результатов испытаний пробной статической нагрузкой, из которых отобраны 4600. В институте Фундаментпроект более чем из 6000, отобраны 3200 , в НИИОСПе из 3500 отобраны 2700.

В общей сложности из отчетных материалов диссертационных и печатных работ просмотрены более 30000 результатов испытаний свай, из которых отобраны для предварительной обработки I5820, в том числе 270 результатов испытаний тензометрических свай. 


\section{2. Методика определения несущей способности одиночной сваи по результатам испытаний пробной статической нагрузкой}

Современный подход к определению частного значения предельного сопротивления одиночной сваи $F_{u}$ по данным статических испытаний (СП 50102-2003), в подавляющем большинстве случаев связывается не с фиксацией ее действительного предельного состояния (срыв сваи), а с величинами предельных осадок фундаментов проектируемых зданий $\left(S=\xi \cdot S_{u, m t}\right)$. Такая трактовка величины $F_{u}$ никак не соответствует принятому в механике грунтов понятию "предельной несущей способности".

Попытка связать предельное сопротивление сваи $F_{u}$ с предельными осадками фундамента $S_{u, m t}$ заданным постоянной величины коэффициентом $\xi=0,2$ не может считаться научно обоснованной, т.к. в этом случае остаются без рассмотрения многочисленные факторы, обладающие значительной неопределенностью и изменчивостью (режим испытания сваи, ее сечение и длина, инженерно-геологические условия площадки, тип и конструкция свайного фундамента, взаимное влияние свай, грунта межсвайного пространства и ростверка и т.п.). Очевидно, хорошо понимая это, СП 50-102-2003 отмечает "значения коэффициента допускается уточнять по результатам наблюдений за осадками зданий, построенных на свайных фундаментах в аналогичных грунтовых условиях". Однако на практике подобные уточнения практически не производятся.

Тем не менее, известны данные по сопоставлению наблюденных осадок зданий на свайных фундаментах и осадок одиночных свай, испытанных при проектировании этих зданий [4.5.6 и др.], показывающие, что значение коэффициента $\xi$ в ряде случаев может быть увеличено до 0,25-0,30. 
Такие рекомендации определения величины $F_{u}$ приводят к значительному преуменьшению этой величины не только исходя из условия несущей способности, но и по деформациям. Например, на основании проведенных комплексных исследований А.А.Бартоломей установил, что фактические осадки ленточных свайных фундаментов, несущая способность которых определялась в соответствии с рекомендациями СНиП (СП) составляют 15-20 мм, т.е. в 4-6 раз меньше минимальных значений предельно допустимых для зданий и сооружений [5].

Переход от предельного сопротивления одиночной сваи $F_{u}$ к величине ее несущей способности $F_{d}$ производится с помощью коэффициентов $\gamma_{c}$ и $\gamma_{g}$. При выборе $F_{u, n}=F_{u, \min }$, в соответствии со СП $\gamma_{c}=\gamma_{g}=1$, т.е. $F_{u, n}=F_{d}$. В остальных случаях $\gamma_{c}=1$, а методика статистического определения принимается та же, что и для образцов грунта. И, наконец, расчетная нагрузка на сваю $\mathrm{N}_{\mathrm{d}}$, определяемая как $N_{d} \leq \frac{F_{d}}{\gamma_{\kappa}}$ где $\gamma_{\kappa}$ - постоянный коэффициент, также вызывает сомнение.

Нами предложен иной подход к определению критических нагрузок на сваю при ее статических испытаниях, основанный на следующих предпосылках:

1) поскольку в процессе испытания сваи в тех случаях, когда не удается достичь ее срыва, предельная нагрузка не достигается, следует отказаться от условного понятия "нормативное" или "частное значение предельного сопротивления сваи" $F_{u, n}$ или $F_{u}$, т.к. оно не соответствует смыслу этого понятия, принятому в механике грунтов, а ее величина устанавливается из произвольных условий в зависимости от предельных осадок проектируемых зданий; 
2) в качестве основного критерия следует использовать понятие "несущей способности сваи", соответствующее такой нагрузке, при которой обеспечивается наиболее полная реализация сил трения грунта по боковой поверхности и сопротивления грунта под острием и осадка сваи полностью затухает во времени;

3) критерий для определения несущей способности сваи должен отражать характер взаимодействия сваи с грунтом и условия ее испытания, быть достаточно простым, удобным для практического применения и включать те параметры, которые в обязательном порядке приводятся в результатах стандартных испытаний;

4) критерий для определения несущей способности сваи не должен для одних и тех же грунтовых условий и типоразмеров свай приводить, как это имеет место сейчас, к различным результатам;

5) переход от величины несущей способности сваи, определяемой в результате статических испытаний, к величине расчетной нагрузки на сваю $\mathrm{N}_{\mathrm{d}}$ должен основываться на положениях теории надежности.

Исследования многих авторов, а также сопоставительный анализ результатов стандартных испытаний свай статической нагрузкой, проведенных в различных грунтовых условиях с различными размерами свай, показывают, что на характер кривой $S=f(F)$, по которой устанавливается критерий несущей способности, влияют величина ступени нагрузки, $\Delta F_{i}$ время ее выдержки $\Delta t_{i}$, осадку сваи, как от каждой ступени нагрузки $\Delta S_{i}$, так и от начала загружения $S_{i}$. К примеру, согласно ГОСТ 5686-78 можно принимать ступени загружения от $\frac{1}{10}$ до $\frac{1}{15}$ предполагаемого предельного сопротивления сваи $F_{u}$. Предположим $F_{u}=1000 \mathrm{\kappa H}$, тогда можно принимать ступени нагрузки $\frac{1}{10} \cdot F_{u}=100 \mathrm{\kappa H}$, можно $\frac{1}{15} \cdot F_{u}=67$ кн. 
В среднем допускаемый диапазон ступени загружения отличается в 1,5 раза. В реальных же результатах стандартных испытаний свай, из-за невозможности точного прогнозирования величины предельного сопротивления, ступени загружения колеблется от $\frac{1}{5}$ до $\frac{1}{20} F_{u}$.

Это, несомненно, сказывается на результатах испытаний. Поэтому в критерии несущей способности необходимо учитывать как величину ступени загружения, так и времени ее выдержки, следовательно, и величину осадки сваи от каждой ступени. Хотя время условной стабилизации также регламентируется ГОСТом, в зависимости от вида и состояния грунта, которые залегают под нижним концом сваи, равной 0,1 мм либо за 1 час, либо за 2 часа, но не учитывается вид и состояние грунта вдоль боковой поверхности, а главное суммарное количество времени выдержки ступени загружения, которые также должны отражаться в результатах испытаний свай.

Были рассмотрены и проанализированы различные комбинации указанных выше параметров. Оказалось, что наиболее чутко реагирует на условия статических испытаний сваи критерий, названной автором "коэффициентом статической деформации" $\mathrm{K}_{\mathrm{s}}$, который для каждой ступени нагружения может быть определен по формуле

$$
K_{S}=\frac{\Delta S_{i}}{\Delta t_{i}} \Delta F_{i} \cdot \Delta S_{i}\left[\frac{\text { M. }^{2}}{\text { мuн }} \kappa H\right]
$$

здесь $\Delta S_{i}$ - приращение осадки сваи при $i$-й ступени нагружения, мм

$\Delta t_{i}$ - время выдерживания $i$-й ступени нагрузки , мин;

$\Delta F_{i}-i$-я ступень нагрузки, кН;

$S_{i}$; - величина осадки сваи от начала нагружения до конца действия $i$-й ступени нагрузки, мм. 
Проанализируем характер изменения величины коэффициента статической деформации $K_{s i}$ на весьма характерном примере результатов испытания сваи сечением 35х35 см, глубиной погружения 10 м, проведенного Санкт-Петербургском ПКТИ (табл.1). Свая прорезала мелкие и пылеватые водонасыщенные пески средней плотности и опиралась на плотный водонасыщенный пылеватый песок.

Таблица 1

\begin{tabular}{|c|c|c|c|c|c|c|c|}
\hline \multicolumn{2}{|c|}{ Нагрузки, кН } & \multirow{2}{*}{$\begin{array}{c}\text { Время } \\
\text { Выдер- } \\
\text { жки на } \\
\text { ступени } \\
\Delta t_{i} \\
\text { мин }\end{array}$} & \multicolumn{2}{|c|}{ Осадка, мм } & \multirow[b]{2}{*}{$\begin{array}{l}\frac{\Delta S_{i}}{\Delta t_{i}}, \\
\frac{M \mu}{M u н}\end{array}$} & \multirow[b]{2}{*}{$\begin{array}{l}\frac{\Delta S_{i}}{\Delta t_{i}} \Delta F_{i}, \\
\frac{M M}{M u H} \cdot \kappa H\end{array}$} & \multirow[b]{2}{*}{$\begin{array}{c}K_{s i} \\
\frac{\mathcal{M M}^{2}}{\mathcal{M u H}} \cdot \kappa H\end{array}$} \\
\hline $\begin{array}{l}\text { сту- } \\
\text { пень } \\
\Delta F_{i}\end{array}$ & $\begin{array}{c}\text { с начала } \\
\text { испытания } \\
F_{i}\end{array}$ & & $\begin{array}{c}\text { на } \\
\text { ступени } \\
\Delta S_{i}\end{array}$ & $\begin{array}{c}\text { с начала } \\
\text { испытания, } \\
S_{i}\end{array}$ & & & \\
\hline 200 & 200 & 120 & 0,76 & 0,76 & $6,33 \cdot 10^{-3}$ & 1,27 & 0,96 \\
\hline 200 & 400 & 120 & 0,94 & 1,70 & $7,83 \cdot 10^{-3}$ & 1,57 & 2,67 \\
\hline 150 & 550 & 330 & 3,79 & 5,49 & $11,48 \cdot 10^{-3}$ & 1,72 & 9,46 \\
\hline 100 & 650 & 330 & 7,37 & 12,86 & $22,33 \cdot 10^{-3}$ & 2,23 & 28,72 \\
\hline 100 & 750 & 450 & 13,19 & 26,05 & $29,31 \cdot 10^{-3}$ & 2,93 & 76,35 \\
\hline 50 & 800 & 150 & 24,50 & 50,55 & $163,33 \cdot 10^{-3}$ & 8,17 & 412,82 \\
\hline
\end{tabular}

Данные таблицы 1 позволяют установить, что характер зависимости $K_{s}=f(F)$, особенно на последних ступенях испытания, гораздо более выразительно иллюстрирует изменчивость процесса осадки сваи, чем обычная зависимость $S=f(F)$. Это хорошо подтверждается данными табл. 2, где $S_{i} / S_{1}$ отношение полной осадки на $i$-й ступени нагружения сваи к осадке после первой ступени и $K_{s i} / K_{s 1}$ - аналогичное отношение коэффициентов статической 
деформации. Такой же вывод можно сделать из рассмотрения графиков на рис. 1.

Таблица 2

\begin{tabular}{|c|c|c|c|c|c|c|}
\hline$F_{i}$ & 200 & 400 & 550 & 650 & 750 & 800 \\
\hline$S_{i} / S_{1}$ & 1 & 2.24 & 7.22 & 16,92 & 34,28 & 66,51 \\
\hline$K_{s i} / K_{s 1}$ & 1 & 2,72 & 9,85 & 29,92 & 79,53 & 430,02 \\
\hline
\end{tabular}

Действительно, "чувствительность" изменения коэффициента $K_{s i}$ при увеличении действующего усилия на сваю $F_{i}$ определяется его структурой (см. табл. 1). Соотношение $\frac{\Delta S_{i}}{\Delta t_{i}}$, входящее в состав коэффициента $K_{s i}$, особенно сильно проявляется на последней ступени нагружения, где условная стабилизация осадок, практически, не достигается. В этом случае, поскольку максимальная доля осадки развивается непосредственно после загружения сваи, соотношение $\frac{\Delta S_{i}}{\Delta t_{i}}$, становится наибольшим и весьма сильно влияет на величину $K_{s i}$. Учет ступени нагружения $\Delta F_{i}$ в составе коэффициента $K_{s i}$ показывает на каком участке изменения нагрузки происходит развитие как самой осадки, так и скорости осадки. Наконец, величина полной осадки $S_{i}$ на каждой ступени нагружения, особенно в конце испытаний, еще более увеличивает кривизну зависимости $K_{s i}=f\left(F_{i}\right)$.

Показанные на приведенном примере закономерности зависимости $K_{s i}=f\left(F_{i}\right)$ были проверены более чем на 100 опытах со статическим нагружением свай и оказались весьма устойчивыми. 


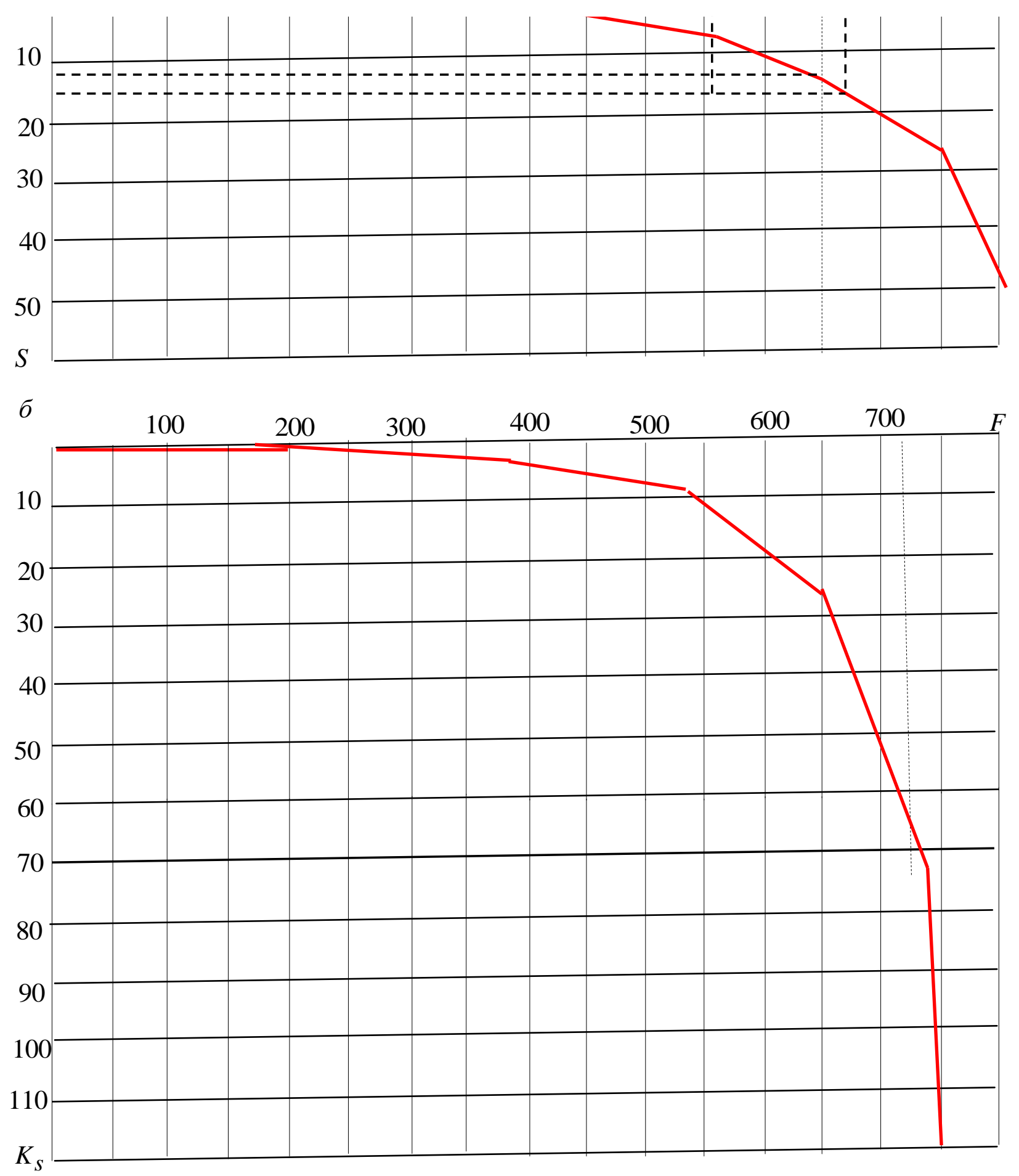

Рис. 1. Зависимости осадки сваи $S$ (а) и коэффициента статической деформации Кs (б) от нагрузки $F$ 
Первоначальный анализ результатов испытаний более чем 100 натурных свай, подтвержденный затем обработкой всей совокупности рассмотренных в диссертации испытаний свай разных типоразмеров в разных грунтовых условиях (I5820 свай) позволили, для определения несущей способности одиночной сваи, установить следующие критерии величины $K_{s}$ :

I группа $-K_{S}=60 \frac{\mathcal{M м}^{2}}{\mathcal{M u}} \cdot \kappa H$, если при изменении $K_{S}$ от 50 до $70 \frac{\mathcal{M M}^{2}}{\mathcal{M \mu}} \cdot \kappa H$, нагрузка на сваю меняется в пределах от 10 до 20 кН;

II группа $-K_{s}=50 \frac{\mu^{2}}{\text { мин }} \cdot \kappa H$, если при том же изменении $K_{S}$ от 50 до $70 \frac{\mu^{2}}{\text { мин }} \cdot \kappa H$, нагрузка на сваю меняется в пределах до 10 кН;

III группа $K_{S}=70 \frac{\mu^{2}}{м и н} \cdot \kappa H$, если в тех же пределах изменения $K_{S}$ от 50 до $70 \frac{\text { м }^{2}}{\text { мин }} \cdot \kappa H$, нагрузка меняется более чем на 20 кН.

Покажем пример использования предлагаемой методики для определения несущей способности сваи для случая, представленного в таблице 1 (см. рис. 1). По существующей методике СП для зданий с предельной величиной осадки $S_{u, m t}=8$ см получаем: $F_{u}=670$ кН (при $\mathrm{S}=16$ мм) и $N_{d}=\frac{670}{1,2}=558$ кН (при $\mathrm{S}=6$ мм). Если в качестве предельной осадки сваи принять 40 мм, то $F_{u}$ $=780$ кН и $N_{d}=\frac{780}{1,2}=650$ кН (при $\mathrm{S}=13$ мм).

Поскольку эта же свая в пределах изменения $K_{S}$ от 50 до 70 характеризуется изменением $F_{i}$. равным 40 кН, относим ее к III группе. 
Частное значение несущей способности сваи, соответствующей коэффициенту статической деформации $K_{S}$ нами обозначено буквой $F_{S}$.

Тогда для рассмотренного примера значение $F_{S}$ определяется при $K_{S}=70 \frac{\mu^{2}}{м и н} \cdot \kappa H$ и составляет $F_{S}=730 \kappa \mathrm{H}$.

Заметим, что в отличие от методики СП, по предложенной методике, несущая способность сваи определяется непосредственно, минуя предельное сопротивление.

Расчетная же несущая способность сваи нами обозначена буквой $F$ и определяется из условия:

$$
N_{d} \leq F=\frac{\overline{F_{s}}}{\gamma_{g}},
$$

где $\bar{F}_{S}$ - среднее арифметическое, равное нормативной несущей способности свай $\left(F^{H}\right)$, определяемое по частным значениям $F_{s}$, в соответствии с коэффициентом статической деформации $K_{S}$;

$$
\begin{aligned}
& N_{d} \text { - расчетная нагрузка, передаваемая на одиночную сваю; } \\
& \gamma_{g} \text { - ко - коэффициент надежности по грунту. }
\end{aligned}
$$

На рис. 2 представлены характерные графики зависимости $S_{i}=f\left(F_{i}\right)$ и $K_{s i}=f\left(F_{i}\right)$ для различных групп, построенные по результатам натурных испытаний, проведенных с разными размерами свай в различных грунтовых условиях. Первая группа (кривые $1,2,6)$ соответствует достаточно спокойному изменению кривизны зависимости $S_{i}=f\left(F_{i}\right)$, вторая (кривые 3,5$)$ - характерна 
для испытаний, когда последняя ступень нагружения приближается или достигает срыва, третья (кривые 4,7 и 8) - более плавному изменению кривизны.

Весьма интересно сравнивать несущие способности и расчетные нагрузки на сваи, а также им соответствующие осадки по предложенной методике с существующими.

Такое сравнение для результатов испытаний свай, приведенных на рис. 2 при коэффициенте надежности $03 \gamma_{g}=1$, представлено в табл. 3. При этом несущая способность свай, определенная в соответствии с коэффициентом статической деформации $K_{S}$ согласно условиям (2) будет равна расчетной нагрузке, т.е.:

$$
N_{d}=F=F_{s} .
$$

А для существующих методик:

$$
N_{d}=\frac{F_{d}}{\gamma_{\kappa}}, \text { где } \gamma_{\kappa}=1,2 \text {. }
$$

Анализируя данные таблицы 3 и рис.2 можно отметить, что значения $F_{s}$, в 1,21..1,38 раза больше, чем нагрузка на сваи определенная при осадке $\mathrm{S}=16$ мм согласно методике СП и 1,06... 1,19 раза больше чем нагрузка, определенная при осадке 40 мм.

Важно отметить, что по предложенной методике не только более полно используется несущая способность сваи, но и достигается более равномерная осадка, несмотря на резкое различие характера кривых $S_{i}=f\left(F_{i}\right)$. 

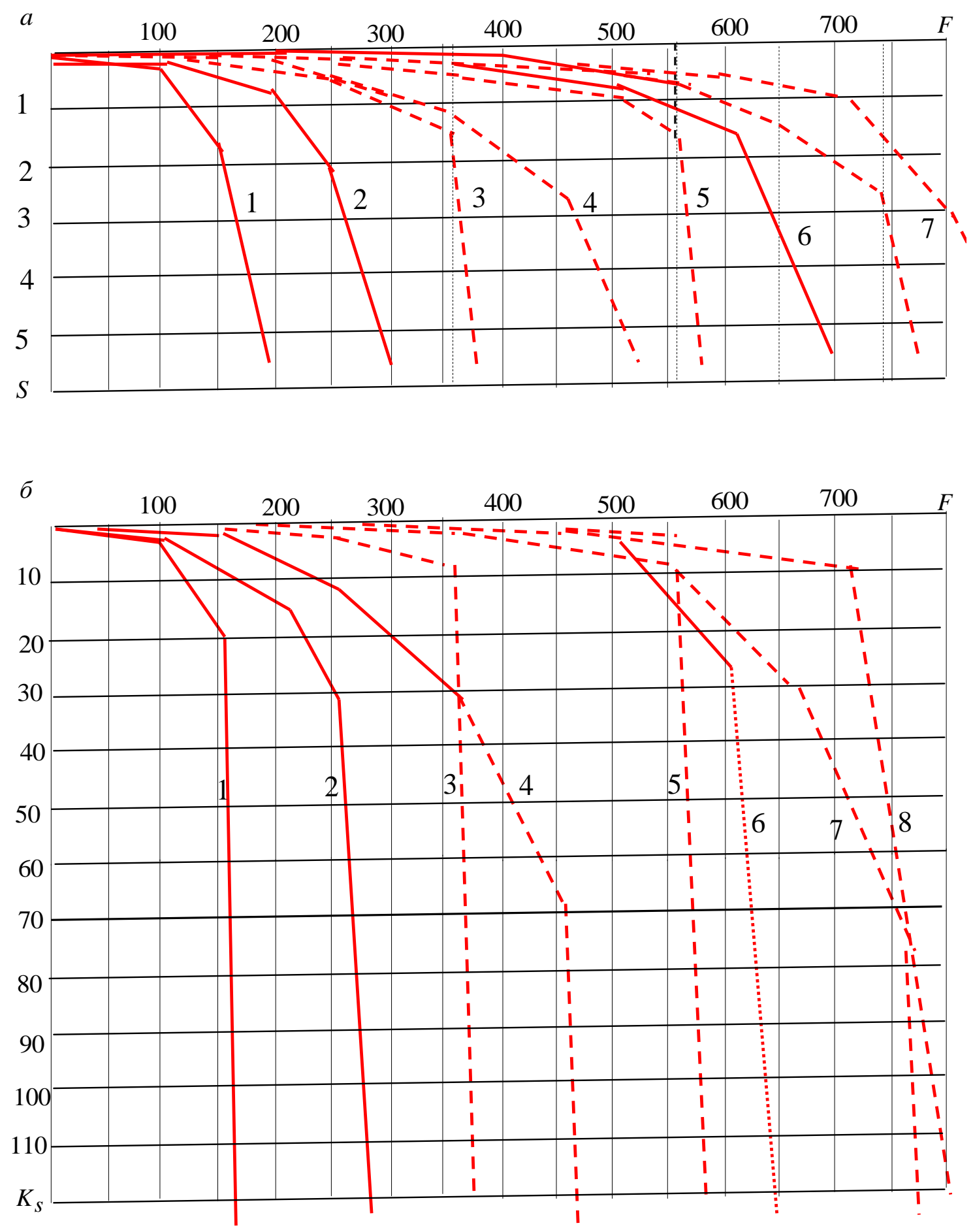

Рис. 2. Зависимости осадки (а) и коэффициента статической деформации (б) от нагрузки на сваи:

1, 2, 6 - плавное достижение предельной нагрузки (I группа);

3,5 - достижение предельной нагрузки при срыве (II группа);

4, 7, 8 - установление несущей способности из-за абсолютной осадки (III группа); 
Таблица 3

Сравнение несущей способности, расчетной нагрузки и осадки сваи

\begin{tabular}{|c|c|c|c|c|c|c|c|c|c|c|c|}
\hline \multirow{3}{*}{ 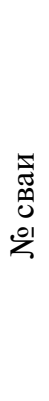 } & \multicolumn{6}{|c|}{ Существующая методика } & \multicolumn{3}{|c|}{$\begin{array}{c}\text { По предложенной } \\
\text { методике }\end{array}$} & \multicolumn{2}{|c|}{$\underset{\substack{\text { при } \\
1,2 \cdot F_{s} / N_{d}}}{ }$} \\
\hline & \multicolumn{3}{|c|}{ При $\mathrm{S}=16 \mathrm{~mm}$} & \multicolumn{3}{|c|}{ При $\mathrm{S}=40 \mathrm{~mm}$} & \multirow{2}{*}{$\begin{array}{c}K_{S}, \\
\frac{M M^{2}}{M u H} \kappa H\end{array}$} & \multirow{2}{*}{$\begin{array}{l}N_{d} \cdot \\
\cdot F_{s}\end{array}$} & \multirow{2}{*}{$\begin{array}{c}\mathrm{S}, \\
\mathrm{mm}\end{array}$} & \multirow{2}{*}{$\begin{array}{l}S= \\
=16 \\
m m\end{array}$} & \multirow{2}{*}{$\begin{array}{l}S= \\
=40 \\
m m\end{array}$} \\
\hline & $\begin{array}{r}F_{d} \\
\text { кН }\end{array}$ & $\begin{array}{l}N_{d}= \\
=F_{d} / 1,2 \\
\text { кН }\end{array}$ & $\begin{array}{l}\text { S при } \\
N_{d} \\
\text { мм }\end{array}$ & $\begin{array}{r}F_{d} \\
\text { кН }\end{array}$ & $\begin{array}{l}N_{d}= \\
=\underset{d}{F_{d}} / 1,\end{array}$ & $\begin{array}{l}\text { S при } \\
N_{d} \\
\text { мм }\end{array}$ & & & & & \\
\hline 1 & 150 & 125 & 10 & 175 & 146 & 16 & 60 & 155 & 20 & 1,24 & 1,06 \\
\hline 2 & 230 & 192 & 6 & 275 & 229 & 15 & 60 & 260 & 25 & 1,35 & 1,14 \\
\hline 3 & 350 & 292 & 9 & 365 & 304 & 10 & 50 & 360 & 23 & 1,23 & 1,18 \\
\hline 4 & 390 & 325 & 9 & 480 & 400 & 18 & 70 & 450 & 24 & 1,38 & 1,13 \\
\hline 5 & 550 & 458 & 6,5 & 560 & 467 & 7 & 50 & 555 & 22 & 1,21 & 1,19 \\
\hline 6 & 605 & 504 & 5,5 & 650 & 542 & 9 & 60 & 610 & 20 & 1,21 & 1,13 \\
\hline 7 & 670 & 558 & 5,0 & 765 & 638 & 11 & 70 & 730 & 25 & 1,31 & 1,14 \\
\hline 8 & 735 & 613 & 4 & 810 & 675 & 8 & 70 & 745 & 20 & 1,22 & 1,10 \\
\hline
\end{tabular}

$\mathrm{x}$ - несущая способность $\mathrm{F}_{\mathrm{S}}$ при соответствующих значения $\mathrm{K}_{\mathrm{S}}$

Так, например, минимальная и максимальная осадки, соответствующие $F_{s}$ установленные по результатам испытаний представленных на рис. 2. составляют $S_{\min }=20 \mathrm{~mm}, S_{\max }=25 \mathrm{~mm}$ (см. табл. 3). Отношение $\frac{25}{20}=1,25$. А по существующим методикам от 4 до 10 мм - при $\mathrm{S}=16$ мм, от 7 до 18 мм при $\mathrm{S}=40$ мм, а отношение $S_{\max }$ к $S_{\min }$, соответственно, составляют $\frac{10}{4}=2,5$ и $\frac{18}{7}=2,6$.

Согласно предложенной методике была определена несущая способность 14700 свай из 15820 результатов их испытаний. Результаты 1120 свай были исключены из дальнейшего анализа из-за невозможности достижения несущей способности по коэффициенту статической деформации 
$K_{S}$, что объясняется недостаточностью в материалах испытаний параметров, от которых зависит коэффициент $K_{S}$.

Последующая обработка результатов массовых стандартных испытаний 14700 свай разных типоразмеров, проведенных в разнообразных грунтовых условиях, показала, что при определении несущей способности сваи по предложенной методике их осадки составили не менее 16 мм и не более 26 мм. Тогда как по существующим методикам осадка свай, соответствующая расчетной нагрузке, изменялась в довольно широких пределах от 3 до 30 мм и более.

Надо полагать, что использование приведенных критериев несущей способности свай, позволяет не только более достоверно обработать результаты стандартных испытаний свай пробной статической нагрузкой, но и дает возможность уменьшить трудоемкость и продолжительность этих испытаний, главное соответствует соотношениям осадок эксплуатируемых зданий и сооружений, построенных на таких фундаментах [4,5,6 и др].

\section{3. Методика разделения несущей способности свай на сопротивление острия и боковой поверхности}

В разделе 1 было показано, что из-за большого числа факторов, от которых зависит несущая способность свай, не разделив ее на сопротивление грунта под острием $R^{s}$ и по боковой поверхности $f^{s}$, невозможно анализировать, тем более обобщать результаты их массовых испытаний пробной статической нагрузкой. Поэтому, с целью обеспечения однородности, в качестве единицы наблюдения принимаются величины $R^{s}$ и $f^{s}$, а не несущая способность свай.

С целью внесения ясности при дальнейшем изложении результатов исследований приняты следующие обозначения: 
$R^{s}$ и $f^{s}$ частные значения сопротивлений устанавливаемые в результате разделения частных значений несущей способности сваи $F^{s}$;

$\bar{R}^{S}$ и $\bar{f}^{S}$ - осредненные (средние арифметические) значения $R^{S}$ и $f^{s}$;

$R^{S}$ и $f^{s}$ - нормативные, принимаемые равными среднеарифметическим значениям $\bar{R}^{s}$ и $\bar{f}^{s}$ при достаточной представительности выборки;

$R$ и $f$ - расчетные значения сопротивлений.

Значения $R^{s}$ и $f^{s}$ являются главными входными параметрами вероятностно-статистической обработки и обобщения результатов массовых испытаний свай; осуществляемых с целью совершенствования метода оценки несущей способности и обеспечения оптимальной надежности при проектировании свайных фундаментов. Достижение этой цели возможно лишь при обеспечении точности и достоверности методики определения несущей способности свай и ее разделении на сопротивления $R^{s}$ и $f^{s}$.

Следует отметить что имеющиеся табличные значения $R \quad$ и $f$ были получены в результате разделения величины предельной нагрузки на сваи, установленной по результатам статических испытаний $[1,3]$.

Строго говоря, разделяя предельное сопротивление сваи с целью определения $R$ и $f$ должны были получить не нормативные их величины, а предельные. Механизм же перехода от предельных значений $R \quad$ и $f \quad$ к нормативным в указанных работах не рассматривается.

Более обоснованным следует считать разделение не предельной нагрузки на сваи для получения $R^{s}$ и $f^{s}$, а ее несущей способности, т.е. такой максимально возможной передаваемой нагрузки на сваи, при которой обеспечивается нормальная эксплуатация зданий и сооружений. Осредненные же значения $\bar{R}^{s}$ и $\bar{f}^{s}$ из достаточной выборки, в соответствии с теорией вероятностей, дают нормативные их значения [2,3,7]. 


\section{СТРАТЕГИЯ НАУЧНО-ТЕХНОЛОГИЧЕСКОГО РАЗВИТИЯ РОССИИ: ПРОБЛЕМЫ И ПЕРСПЕКТИВЫ РЕАЛИЗАЦИИ}

Для перехода от нормативных значений $R^{H}$ и $f^{H}$ к расчетным $R$ и $f$ вводится коэффициент надежности, характеризующий статистическую изменчивость, главным образом, грунтовых условий с учетом доверительной вероятности.

Отобранная для статистического анализа совокупность натурных испытаний обеспечивала возможность разработать не только методику определения несущей способности одиночной сваи по результатам ее статических испытаний, позволившую избежать отмеченныевыше противоречия, но и методику разделения несущей способности $R^{s}$ и $f^{s}$

Для получения значений $R^{s}$ и $f^{s}$, отражающих влияние большого числа параметров грунтовых условий, используется следующая методика, Рекомендуется использовать решение системы линейных уравнений, составленных по результатам параллельных испытаний однотипных свай пробной статической нагрузкой. Непременными условиями при составлении уравнений является прорезание сваями одних и тех же инженерногеологических элементов (напластований грунтов), выделенных по характеристикам грунтов согласно статистическим критериям с допустимым отклонением границы их разделов. При этом толщина слоев вдоль боковой поверхности свай может меняться, тот или иной слой у отдельных свай отсутствовать.

Однако глубины погружения в несущий слой, являющийся для всех свай единым, должны составить примерно одинаковые величины.

При прорезании сваями $n$ слоев, для определения $R^{s}$ и $f^{s}$, составляется система $n+1$ линейных уравнений, для чего требуется такое же число результатов испытаний, отвечающих вышеуказанным требованиям. К примеру, когда сваи прорезают 3 слоя (рис.3), требуется составить систему из 4 линейных уравнений по результатам испытаний 4 свай: 


$$
\begin{aligned}
& u \cdot h_{1}^{I} \cdot f_{1}^{s}+u \cdot h_{2}^{I} \cdot f_{2}^{s}+u \cdot h_{3}^{I} \cdot f_{3}^{s}+A \cdot R_{3}^{s}=F_{s}^{I} \\
& u \cdot h_{1}^{I I} \cdot f_{1}^{s}+u \cdot h_{2}^{I I} \cdot f_{2}^{s}+u \cdot h_{3}^{I I} \cdot f_{3}^{s}+A \cdot R_{3}^{s}=F_{s}^{I I} \\
& u \cdot h_{1}^{I I I} \cdot f_{1}^{s}+u \cdot h_{2}^{I I I} \cdot f_{2}^{s}+u \cdot h_{3}^{I I I} \cdot f_{3}^{s}+A \cdot R_{3}^{s}=F_{s}^{I I I} \\
& u \cdot h_{1}^{I V} \cdot f_{1}^{s}+u \cdot h_{2}^{I V} \cdot f_{2}^{s}+u \cdot h_{3}^{I V} \cdot f_{3}^{s}+A \cdot R_{3}^{s}=F_{s}^{I V}
\end{aligned}
$$

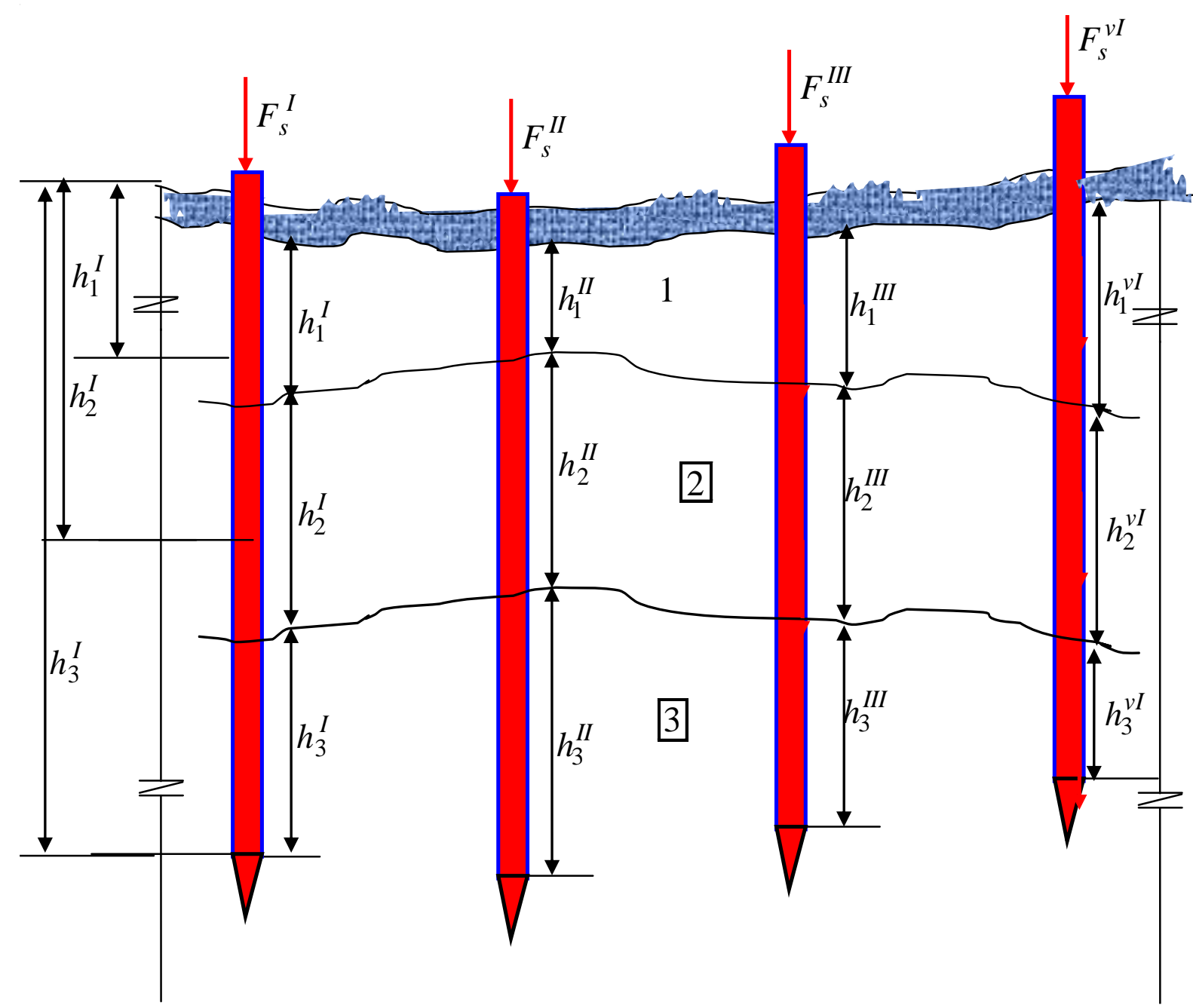

Рис. 3. Расчетная схема к решению линейных уравнений типа (3)

где $u, \mathrm{~A}-$ соответственно, периметр и площадь поперечного сечения сваи; 
$f_{1}^{s} \ldots f_{3}^{s}$ - соответственно, искомые величины сопротивления трех слоев грунта по боковой поверхности сваи;

$R_{3}^{S}$ - искомые величины сопротивления 3-го несущего слоя грунта под острием сваи;

$h_{1}^{I} \ldots h_{3}^{I V}$ - соответственно, толщина трех слоев грунта у боковой поверхности I...IV сваи;

$F_{S}^{I} \quad \ldots F_{S}^{I V}$ - соответственно, несущая способность I...IV сваи, установленная согласно критериям коэффициента статической деформации $K_{S}$ (см. раздел.2).

Система линейных уравнений типа (3) позволяет получать средние арифметические значения $\bar{R}^{s}$ и $\bar{f}$ на соответствующих глубинах $h_{R}, h_{f}$ из параллельных испытаний свай с учетом размеров сваи и характеристик грунтов.

Решение уравнений производилось на ЭВМ по методу Г. Крамера с применением определителей. В качестве примера рассмотрим системы 4 уравнений с 4-мя неизвестными, составленные по результатам 4-х параллельных испытаний 12-метровых свай сечением 35x35 см, проведенных ПИК Укрспецстройпроекта на одной из строительных площадок Днепропетровской области. Согласно расчетной схеме, представленной на рис.3, параметры линейных уравнений (3) имели следующие значения:

$\mathrm{U}=1,4 \mathrm{~m} ; \mathrm{A}=0,1225 \mathrm{~m}^{2} ; h_{1}^{I}=4,8 \mathrm{M} ; h_{1}^{I I}=4,1 \mathrm{M} ; h_{1}^{I I I}=4,3 \mathrm{M} ; h_{1}^{I V}=5,7 \mathrm{M} ; h_{2}^{I}$ $=3,7 \mathrm{~m} ; h_{2}^{I I}=4,6 \mathrm{~m} ; h_{2}^{I I I}=4,2 \mathrm{M} ; h_{2}^{I V}=3,9 \mathrm{~m} ; h_{3}^{I}=1,6 \mathrm{~m} ; h_{3}^{I I}=1,1 \mathrm{M} ; h_{3}^{I I I}=1,8 \mathrm{~m} ; h_{3}^{I V}$ $=1,5 \mathrm{M} ; h_{1}^{f}=3,0 \mathrm{M} ; h_{2}^{f}=7,5 \mathrm{M} ; h_{3}^{f}=10,0 \mathrm{M} ; h_{3}^{R}=10,8 \mathrm{M}$.

1 слой-супесь пластичная: $\mathrm{J}_{\mathrm{p}}=0,05 ; \mathrm{J}_{\mathrm{L}}=0,87 ; \mathrm{e}=0,94 ; \mathrm{S}_{\mathrm{r}}=0,83$;

2 слой-суглинок мягкопластичный: $\mathrm{J}_{\mathrm{p}}=0,13 ; \mathrm{J}_{\mathrm{L}}=0,64 ; \mathrm{e}=0,77 ; \mathrm{S}_{\mathrm{r}}=0,82$;

3 слой - песок мелкий средней плотности, водонасыщенный. 
Несущая способность сваи, установленная по методике, изложенной в предыдущем параграфе, при $K_{S}=60 \frac{\mathrm{mm}^{2}}{\text { мин }} \kappa H$, соответственно составила: $F_{S}^{I}=670 \kappa H: F_{S}^{I I}=645 \kappa H ; F_{S}^{I I I}=685 \kappa H ; F_{S}^{I V}=675 \kappa H ;$

Составим систему в соответствии с уравнением (3).

$$
\begin{aligned}
& 1,4 \cdot 4,8 \cdot f_{1}^{s}+1,4 \cdot 3,7 \cdot f_{2}^{s}+1,4 \cdot 1,6 \cdot f_{3}^{s}+0,1225 \cdot R_{3}^{s}=670 \\
& 1,4 \cdot 4,1 \cdot f_{1}^{s}+1,4 \cdot 4,6 \cdot f_{2}^{s}+1,4 \cdot 1,1 \cdot f_{3}^{s}+0,1225 \cdot R_{3}^{s}=645 \\
& 1,4 \cdot 4,3 \cdot f_{1}^{s}+1,4 \cdot 4,2 \cdot f_{2}^{s}+1,4 \cdot 1,8 \cdot f_{3}^{s}+0,1225 \cdot R_{3}^{s}=685 \\
& 1,4 \cdot 5,7 \cdot f_{1}^{s}+1,4 \cdot 3,9 \cdot f_{2}^{s}+1,4 \cdot 1,5 \cdot f_{3}^{s}+0,1225 \cdot R_{3}^{s}=675
\end{aligned}
$$

Для четырех линейных уравнений с четырьмя неизвестными определитель четвертого порядка составит:

$$
\Delta=-0.1529437 \text {. }
$$

Определитель для вычисления искомого $\bar{f}_{1}^{s}$,

$$
\Delta_{f_{1}}=-0.1529437
$$

Тогда $\overline{f_{1}}=\frac{-1,17649}{-0,1529437}=7,69 \kappa \Pi a$

Определитель для вычисления искомого ${\overline{f_{2}}}^{s}$,

$$
\begin{aligned}
& \Delta_{f_{2}}=-2,491552 \\
& \text { Имеем }{\overline{f_{2}}}^{s}=\frac{-2,491552}{-0,1528437}=16,9 \kappa \Pi a
\end{aligned}
$$

Точно также для $\overline{f_{3}} s$

$$
\begin{aligned}
& \Delta_{f_{3}}=-7,311045 \\
& {\overline{f_{3}}}^{s}=\frac{-7,311045}{-0,1529437}=47,80 \kappa \Pi a
\end{aligned}
$$


Наконец определитель для, ${\overline{R_{2}}}^{s}$

$\Delta_{R_{3}}=-543,3932$

Имеем ${\overline{R_{3}}}^{S}=\frac{-543,39432}{-0,1529437}=3553 \kappa \Pi а$

Подстановка значений $\overline{f_{1}}, \overline{f_{2}} s,{\overline{f_{3}}}^{s}$ и ${\overline{R_{2}}}^{s}$ в систему показывает, что общие невязки при принятой в примере точности вычислений составляют для различных условий от 1,5 до 3,0\%,что можно считать вполне допустимым.

В результате решения системы уравнений для рассматриваемого примера имеем среднее арифметическое значение для $\overline{f_{1}}, \overline{f_{2}}, \overline{f_{3}} s$ и ${\overline{R_{2}}}^{s}$ из четырех величин (по результатам четырех испытаний свай), то есть число определений, для каждого из этих сопротивлений равно $\mathrm{n}=4$.

Характерным для массовых стандартных испытаний свай является то, что в зависимости от сложности инженерно-геологических условий строительной площадки и размеров проектируемых зданий в плане, число испытаний составляет от 2 до 6-8, но чаще всего не более 2 или 3 . По результатам же 2 испытаний по предлагаемой методике возможно определить значения $\bar{f}$ и $\bar{R}^{s}$, лишь для однородного грунта, а по результатам 3 испытаний, когда сваи прорезают один слой и опираются на второй. Оказалось, что по результатам стандартных испытаний свай такие "благоприятные" условия для определения $f^{s}$ и $R^{s}$ ограничены. Очень часто число слоев бывает больше и не достает числа испытаний, что приводит, при составлении уравнений, к превышению числа неизвестных.

С целью уменьшения (исключения) неизвестных была использована методика поэтапного определения величин $f^{s}$ и $R^{s}$, заключающейся в следующем: в первую очередь, значения $f^{s}$ и $R^{s}$ были определены непосредственно по результатам испытаний 270 тензометрических свай, затем были определены по результатам параллельных испытаний не менее 2 свай, 
проведенных в однородных грунтовых условиях, затем 3 сваи в двухслойных грунтовых условиях и т.д. Тем самым число определений значений $f^{s}$ и $R^{s}$ постепенно увеличились, расширяясь в диапазоне изменения как грунтовых условий, так и глубины погружения свай.

Таким образом начал формироваться банк данных. Наряду с результатами испытаний тензометрических свай были использованы (порядка 1500 шт.) результаты комплексных, в большинстве случаев параллельных испытаний из нескольких свай, проведенных под руководством, а также при непосредственном участии ведущих специалистов НИИОСПа и ГПИ Фундаментпроект в разнообразных грунтовых условиях по теме "Разработка свай, равнопрочных по несущей способности грунта и материалов".

При превышении числа неизвестных из числа уравнений, исключением одного из неизвестных или двух, проставляя вместо них параметры найденные при обработке результатов других испытаний, накопившихся к этому моменту, решалась система уравнений. Это дало возможность определить значения $f^{s}$ и $R^{s}$ при прорезании сваями до 4-5 слоев грунта.

В качестве примера, когда число неизвестных превышает числа уравнений, рассмотрим систему 3 уравнений с 4-мя неизвестными, составленную по результатам 3-х параллельных испытаний 10-метровых свай, сечением 30х30 см, проведенных ПКТИ, в районе озера Долгое г. Санкт-Петербурга. Параметры линейных уравнений (3) имели следующие значения: $\mathrm{U}=1,2 \mathrm{M} ; \mathrm{A}=0,09 \mathrm{M}^{2} ; h_{1}^{I}=4,6 \mathrm{~m} ; h_{1}^{I I}=3,3 \mathrm{~m} ; h_{1}^{I I I}=1,2 \mathrm{M} ; h_{2}^{I}=3,0 \mathrm{~m} ; h_{2}^{I I}$ $=2,8 \mathrm{м} ; \quad h_{2}^{I I I}=7,2 \mathrm{M} ; \quad h_{3}^{I}=1,5 \mathrm{м} ; h_{3}^{I I}=2,2 \mathrm{м} ; \quad h_{3}^{I I I}=1,4 \mathrm{м} ;$ Средняя глубина расположения слоев составляет: $h_{1}^{f}=1,50 \mathrm{M}, h_{2}^{f}=5,2 \mathrm{M}, h_{3}^{f}=8,3$ м. Средняя глубина погружения сваи: $h_{3}^{R}=9,2$ м.

1 слой - песок пылеватый средней плотности, водонасыщенный, $\rho=1,94$ г $/ \mathrm{cm}^{3}, \varphi=20^{\circ}, \mathrm{c}=1$ кПа, $\mathrm{E}=10$ мПа. 


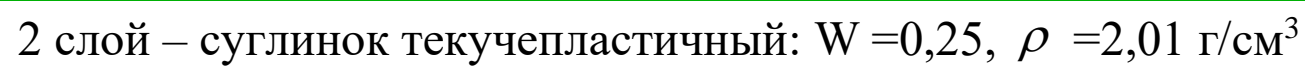

$\mathrm{e}=0,68, \mathrm{~J}_{\mathrm{L}}=0,87, \varphi=20^{\circ}, \mathrm{C}=3,7 \mathrm{M \Pi a}, \mathrm{E}=10,5 \mathrm{M \Pi а}$.

3 слой - песок пылеватый, плотный, водонасыщенный: $\rho=2,10$, г/см3, $\mathrm{e}=0,505, \varphi=31^{\circ}, \mathrm{C}=0,5$ кПа, $\mathrm{E}=21 \mathrm{M \Pi а}$.

Несущая способность сваи, установленная по критерию коэффициента статической деформации $K_{S}=60 \frac{\mathrm{mm}^{2}}{\text { мин }} \kappa H, \quad$ соответственно составляет: $F_{S}^{I}=585 \kappa H: F_{s}^{I I}=615 \kappa H ; F_{s}^{I I I}=590 \kappa H$

Составим системы уравнений:

$$
\begin{aligned}
& 1,2 \cdot 4,6 \cdot f_{1}^{s}+1,2 \cdot 3,0 \cdot f_{2}^{s}+1,2 \cdot 1,5 \cdot f_{3}^{s}+0,09 \cdot R_{3}^{s}=585 \\
& 1,2 \cdot 3,3 \cdot f_{1}^{s}+1,2 \cdot 2,8 \cdot f_{2}^{s}+1,2 \cdot 2,6 \cdot f_{3}^{s}+0,09 \cdot R_{3}^{s}=615 \\
& 1,2 \cdot 1,2 \cdot f_{1}^{s}+1,2 \cdot 7,2 \cdot f_{2}^{s}+1,2 \cdot 1,4 \cdot f_{3}^{s}+0,09 \cdot R_{3}^{s}=590
\end{aligned}
$$

Поскольку число неизвестных $f_{1}{ }^{s}, f_{2}{ }^{s}, f_{3}{ }^{s}$, и $R_{1}{ }^{s}$ превышает число уравнений, исключаем одно из неизвестных, проставляя вместо него параметр, найденный при обработке результатов других испытаний, накопившихся к моменту решения данной системы уравнений.

Так, для плотного пылеватого водонасыщенного песка на глубине погружения 8,75...9,25 м, по данным тензометрических испытаний и ранее решенных уравнений, были получены значения $R^{s}: 3050,30504600,4900$ кПа. Принимаем среднее значение, равное $R_{3}{ }^{s}=3900$ кПа. Тогда несущая способность острия свай составляет 0,09- $3900=351$ кН. Вычитая несущую способность острия от несущей способности каждой сваи, получим соответствующие несущие способности боковой поверхности. В результате получим 3 уравнения с 3-мя неизвестными:

$$
5,52 \cdot f_{1}^{S}+3,60 \cdot f_{2}^{S}+1,80 \cdot R_{3}^{S}=233
$$


$3,96 \cdot f_{1}^{s}+3,36 \cdot f_{2}^{S}+3,12 \cdot R_{3}^{S}=264$

$1,44 \cdot f_{1}^{s}+8,64 \cdot f_{2}^{S}+1,68 \cdot R_{3}^{s}=239$

Решая эти уравнения, мы имеем: $\bar{f}_{1}{ }^{s}=19 \kappa \Pi a, \bar{f}_{2}{ }^{s}=13 \kappa \Pi a$ и $\bar{f}_{3}{ }^{s}=47 \kappa \Pi a$, кПа, а число определений для каждого из $\bar{f}_{i}{ }^{s}$ будет $\mathrm{n}=3$.

Аналогичным образом, но чаще чем $\bar{R} s$, где это возможно, исключены из уравнения значения $\bar{f} s$, учитывая то, что в формировании несущей способности свай, сопротивление острия играет более существенное значение, чем трения по ее боковой поверхности отдельных слоев грунта.

Согласно рекомендациям, приведенным в работах [4,6], трение по торфяным прослойкам не учитывалось, не принималось также в расчет и трение в насыпном слое грунта мощностью до 1 м из-за незначительности.

С целью вероятностно-статистической обработки полученные таким образом значения $\bar{R}^{s}$ и $\bar{f}^{s}$ были систематизированы. Для удобства обработки были составлены специальные карточки по каждому конкретному значению $\bar{f}^{s}$ и $\bar{R} s$, где приводились необходимые данные, имеющиеся в результатах испытаний: физико - механические характеристики слоев грунтов, средняя глубина их залегания (для $\bar{f} s$ ), глубина погружения свай (для $\bar{R}^{s}$ ), размеры сваи, количество), в определениях $\mathrm{n}$ значений $\bar{f}^{s}$ или $\bar{R}^{s}$ (равной числу параллельно испытанных свай) и другие данные, влияющие на случайные величины $\bar{f}^{s}$ и $\bar{R}^{s}$. Образцы таких карточек приведены на рис. 4.

Общее количество карточек составило 15836 штук, в том числе 8942 - для $\bar{f}^{s}$ и 6894 - для $\bar{R}^{s}$.

Отметим, что предложенная методика, в отличие от существующих подходов, позволила разделить несущую способность свай на сопротивление 
грунта под острием и по боковой поверхности, не предъявляя дополнительные требования к условиям испытания. Благодаря этому появилась возможность проводить качественную обработку результатов массовых испытаний свай, проведенных по стандартной методике пробной статической нагрузкой в разнообразных грунтовых условиях и в широком диапазоне изменения размеров сваи.

A)

№ 2641

$$
\begin{aligned}
& \text { Суглинок теку- } \quad \mathrm{d}=30 \times 30 \mathrm{~cm} \\
& \text { чепластичный } \quad 1=10 \mathrm{M} \\
& \bar{f}^{s}=13 \text { кПа, } \mathrm{n}=3, h_{f}=5,2 \mathrm{м}, S_{r}=0,98 \\
& \mathrm{~W}=0,25, \rho=2,01 \text { г/см3, е =0,68 } \\
& J_{L}=0,87, \varphi=20^{\circ}, \mathrm{c}=3,7 \text { кПа } \\
& \mathrm{E}=10,5 \mathrm{MПа} \mathrm{(компрессия)}
\end{aligned}
$$

Испытания проведены ПКТИ, ГРИИ г. С.-Петербург, р-н Озеро - Долгое

Б)

№ 683

$$
\begin{array}{lc}
\text { Песок мелкий, } & \mathrm{d}=35 \times 35 \text { см } \\
\text { водонасыщенный } & \\
\text { средней плотности } & l-12 \mathrm{M} \\
\text { (по зондированию) } & \\
\bar{R}{ }^{s}=3550 \text { кПа, } \mathrm{n}=2, & \mathrm{~h}_{\mathrm{R}}=10,8 \mathrm{M}
\end{array}
$$

Испытания проведены Укрспецстройпроект г. Днепропетровск

Рис. 4. Образцы оформления специальных карточек: а - для $f^{s} ; \boldsymbol{0}$-для $R^{s}$ 


\section{4. Группировка данных $R^{s}, f^{s}$ их дисперсионный анализ}

В результате разделения несущей способности 14700 свай, согласно методике изложенной в предыдущем разделе, были получены 14560 значений $R^{s}$, в том числе 13050 для пылевато-глинистых, 1510 для песчаных грунтов и 20015 значений $f^{s}$, в том числе 18520 для пылевато-глинистых, 1495 для песчаных грунтов. В общей сложности для них были составлены 6894 карточки с разным числом определений для $R^{s}$ и 8942 карточек для $f^{s}$.

Данные $R^{s}$ и $f^{s}$, принятые в качестве единицы наблюдения в том виде как они получены, представляют очень большое число самых разнообразных отметок, в расположении которых трудно заметить какую-либо правильность.

Чтобы создать возможность для исследования закономерности изменения $R^{s}$ и $f^{s}$, прежде всего, необходимо, не изменяя самого существа данных, ввести в них некоторый порядок, сгруппировать, систематизировать и придать им вид удобный для обозрения и обработки. Это возможно лишь при учете значимости тех основных факторов (признаков), от которых зависят величины $R^{s}$ и $f^{s}$.

В результате группировки получаются ряды и таблицы распредления значений $R^{s}$ и $f^{s}$, дающие в кратком виде достаточно ясное представление об их свойствах и изменениях. При этом одним из основных вопросов является обеспечение представительности выборки $R^{s}$ и $f^{s}$ в каждой группе, что зависит от их однородности. Чем больше обеспечивается однородность $R^{s}$ и $f^{s}$, тем меньше потребуется число наблюдения, необходимое для обеспечения представительности их выборки, что подтверждается зависимостью $n$ от 
коэффициента изменчивости (вариации) V представленной на рис. 5, которая построена по данным номограммы больших чисел приведенной в работе [3].

В свою очередь, как было отмечено в первом разделе, для того, чтобы значения $R^{s}$ и $f^{s}$ были однородными, необходимо, чтобы они обладали значительным числом общих признаков (влияющих факторов).

Обеспечение представительности выборки $R^{s}$ и $f^{s}$, по результатам массовых испытаний свай, в отличие от свойств (образца) грунта, бетона или другой продукции заводского изготовления, заранее планировать и, тем более, осуществить этот план практически невозможно.

С целью решения этого вопроса диссертант придерживался довольно простой логики, заключающейся в следующем: максимально, по мере возможности, произвести сбор материалов о результатах массовых испытаний свай. Определив их несущую способность, разделив ее на $R^{s}$ и $f^{s}$, по представительности выборки устанавливается диапазон изменения размеров свай, вид, свойства и состояние грунтов, подлежащих дальнейшей обработке.

При этом представительность выборки устанавливается с использованием зависимости представленной на рис. 5. За пределами границы диапазона, т.е. там, где не обеспечивается представительность выборки $R^{s}$ и исключить их из дальнейшей обработки.

Впрочем, решение последнего вопроса дает ориентировочный ответ и на вопрос каких размеров и в каких грунтовых условиях в наибольшей степени имеют применение на практике свайные фундаменты. 


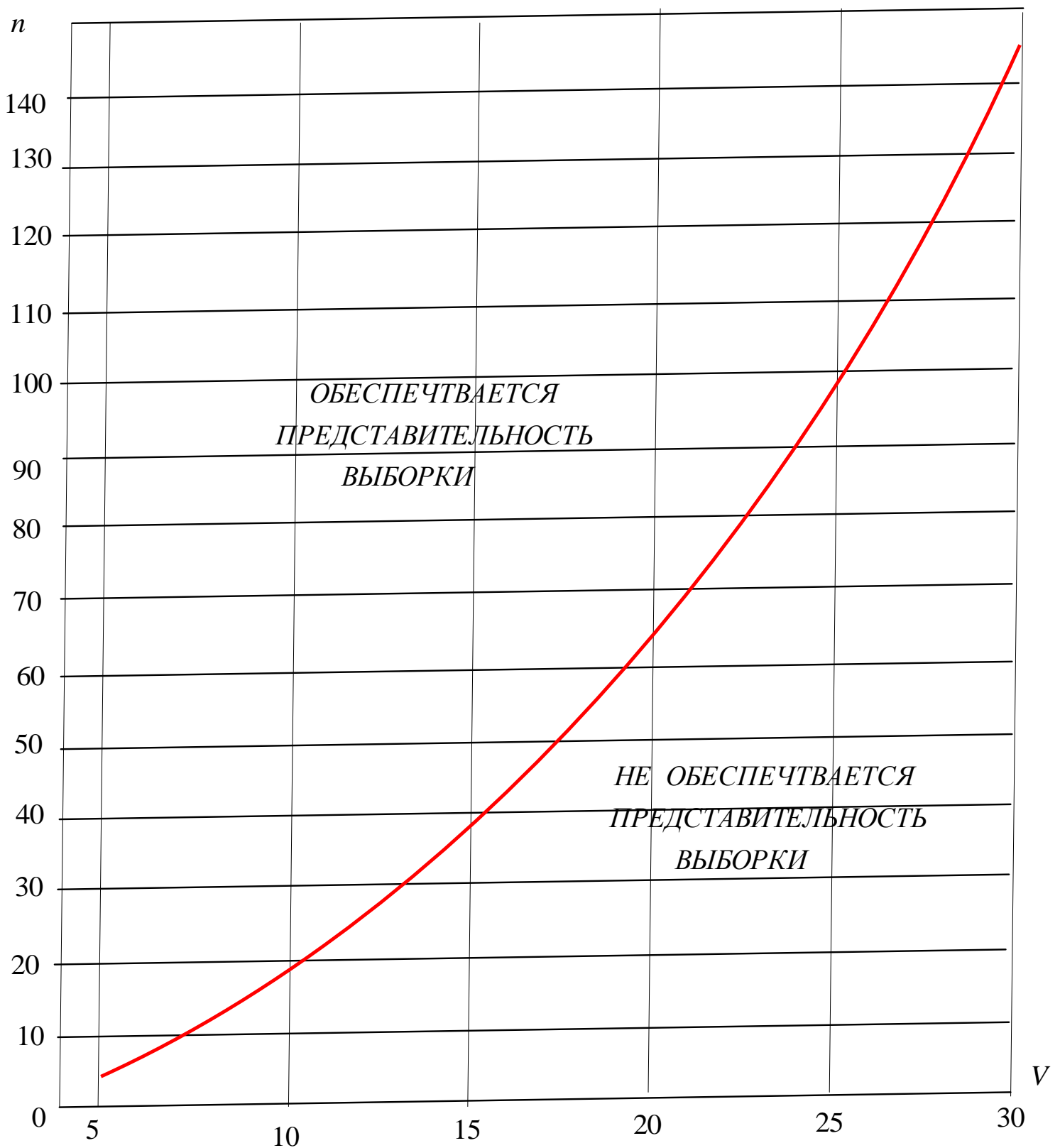

Рис. 5. Зависимости минимального числа определений от коэффциента вариации $\mathbf{V}$, при $\mathbf{P}=\mathbf{0 , 9 5}$ и $\xi=0,05$, согласно номограммы достаточно больших чисел [3]

Исходя из вышеизложенного для исследования статистической $\mathrm{S}$ закономерности случайных величин $R^{s}$ и $f^{s}$, с целью определения их нормативных и расчетных значений необходимо решить следующие основные 
вопросы:

1) установить основные факторы, вызывающие изменчивость случайных величин $R^{s}$ и $f^{s}$;

2) произвести группировку (составить таблицы) значений $R^{s}$ и $f^{s}$ с учетом основных факторов (признаков), вызывающих их изменчивость;

3) определить диапазон изменения величин $R^{s}$ и $f^{s}$ по каждому фактору, в пределах которого обеспечивается представительность выборки;

4) проверить значимость (степень влияния) предполагаемых факторов дисперсионным анализом.

Решение указанных вопросов позволяет произвести последний этап обработки - определение нормативных и расчетных значений $R^{s}$ и $f^{s}$.

Как отмечено в разделе 1 на основании имеющихся исследований, к числу факторов, влияющих на случайные величины $R^{s}$ и $f^{s}$ можно отнести $[1,4,5,6$ и др.]:

а) для пылевато-глинистых грунтов - размеры поперечного сечения свай $d$; глубину ее погружения $h_{R}$ (для $R^{s}$ ); среднюю глубину расположения слоя грунта $h_{f}\left(f^{s}\right)$; число пластичности $J_{p}$; показатель текучести $J_{L}$; коэффициент пористости $e$; степень влажности $S_{r}$; удельное сцепление С, угол внутреннего трения $\varphi$, модуль общей деформации Е. Всего число возможных влияющих факторов на $R^{s}$ и $f^{s}$ составляют по 9;

б) для песчаных грунтов - размеры поперечного сечения свай $d$; глубину ее погружения $h_{R}$ (для $R^{s}$ ); среднюю глубину расположения слоя грунта $h_{f}$ (для $f^{s}$ ); вид песков по крупности; коэффициент пористости е (или плотность их сложения); степень влажности $S_{r}$; удельное сцепление С; угол внутреннего трения $\varphi$; модуль общей деформации Е. Всего число возможных влияющих факторов на $R^{s}$ и $f^{s}$ составляет по 8 . 
Покажем на примере общего числа определений $R^{s}$ пылевато-глинистых грунтов равного I3050, несостоятельность стремления учитывать все возможные влияющие факторы на случайные величины $R^{s}$ и $f^{s}$. Для этого определим среднее число выборки $n_{c p}$ приходящееся на испытания свай конкретного сечения заданной глубины ее погружения и фиксированных свойств грунта.

Учитывая, что описать закономерности изменения $R^{s}$ (или $f^{s}$ ) возможно в том случае, если каждый параметр, от которых зависит $R^{s}$, подразделяется минимум на 3 подгруппы: $3_{J_{P}}{ }^{s}$,- подгруппы по $J_{P} ; 3_{d}$ - по $d$; $3_{S r}-$ по $S_{r}-; 3_{c}-$ по C; $3_{\varphi}-$ по $\varphi ; 3_{E}-$ по Е.

С целью определения числа подгруппы по $J_{i}$, e и $h_{R}$ было изучено распределение $R^{s}$ по этим параметрам. Оказалось, что в наибольшей степени значения $R^{s}$ концентрированы в пределах диапазона: показателя текучести от 0,0 до 1,$0 ;$;оэффициента пористости от 0,5 до 1,0 ; глубины погружения от 3 до $16 \mathrm{M}$.

Разделив на подгруппу значения $R^{s}$ по $J_{L}$ и $e$ через 0,1 единицы, имеем $2_{J_{L}}$, подгруппы по $J ; 6_{\mathrm{e}}$ - по $e$,через 1,0 м по глубине погружения имеем $14_{h_{R}}$ подгруппы для $h_{R}$.

В результате, разделяя общее число определений $R^{S}$ на произведения числа подгрупп всех учитываемых факторов, получим среднее число выборки равной:

$$
n_{c p}=\frac{13050}{3_{J_{p}} \cdot 3_{d} \cdot 3_{S_{r}} \cdot 3{ } \cdot 3_{E} \cdot 2_{J_{L}} \cdot 6_{e} \cdot 14_{h_{R}}}=\frac{13050}{673596}=0.019
$$


Видим, что даже при увеличении числа определений $R^{s}$ в сотни раз не добились бы желаемых результатов. По этой причине дальнейшие исследования были направлены на выявление основных факторов, без которых невозможно построить закономерности изменения $R^{s}$ и $f^{s}$, границы их изменения, за пределами которых не обеспечивается представительная выборка. С этой целью составленные карточки $R^{s}$ и $f^{s}$ по параметрам (см. рис. 4) были многократно перегруппированы и систематизированы, подвергались стандартному дисперсионному анализу [3].

Прежде чем переходить к дисперсионному анализу, который дает формальный ответ на вопрос является или нет тот или иной фактор "значимым" для случайных величин $R^{s}$ и $f^{s}$, необходимо обеспечить однородность их наблюдений, что достигается систематизацией, группировкой и предварительным анализом совокупности наблюдений по составленным таблицам и графикам.

\section{1. Группировка данных значений $R^{s}$ и $f^{S}$}

При группировке значений $R^{s}$ и $f^{s}$ по степени влажности $S_{r}$ оказалось, что из 14560 значений $R^{s}, 12970$ или около 88\% относится к водонасыщенным грунтам, для которых $S_{r} \geq 0,8$. Для $f^{s}$, из 20015 значений 16195 или 81\% относится к водонасыщенным грунтам. Для маловлажных и влажных грунтов из-за недостаточности опытных данных не удалось установить какие-либо закономерности изменения с учетом степени влажности. В связи с этим, а также учитывая то, что в процессе эксплуатации зданий и сооружений их основания подвергаются периодическому изменению влажностного режима, а вероятностно-статистическая обработка значений $R^{s}$ и $f^{s}$ при $S_{r} \geq 0,8$, обеспечивает наихудшие условия, были исключены из дальнейшего 
рассмотрения значения $R^{s}$ и $f^{s}$, относящиеся к маловлажным и влажным грунтам.

В разделе 1 было отмечено, что в более чем 50\% материалов испытаний свай либо отсутствуют прочностные показатели $\varphi$ и $C$, а также модуль общей деформации грунтов Е, либо эти характеристики определены с применением различных методик и приборов. Это вынуждает указанные характеристики ( $\varphi$, $C, E)$ исключить из числа влияющих факторов на случайные величины $R^{s}$ и $f^{s}$, так как не удалось обеспечить представительность выборки и установить какие-либо закономерности изменения $R^{s}$ и $f^{s}$ с учетом этих характеристик.

На основании распределения значений $R^{s}$ и $f^{s}$ по оставшимся параметрам, а также их предварительного дисперсионного анализа, наиболее значимыми факторами, вызывающими их изменчивость предполагались:

- для пылевато-глинистых грунтов показатель текучести $J_{L} \quad$ и коэффициент пористости $e$;

- для песчаных грунтов наименование по крупности и плотность их сложения;

- для обоих видов грунтов глубина погружения свай $h_{R}$ (для $R$ и средняя глубина расположения слоя грунта $h_{f}\left(\right.$ для $f^{s}$ ).

С целью обеспечения более надежных значений $R^{s}$ и при их группировке для непрерывно изменяющихся параметров, от которых они зависят, границы диапазонов были приняты такими, чтобы включали наименьшие их значения.

Например, как для пылевато-глинистых, так и для песчаных грунтов средняя глубина расположения слоя грунта $h_{f}$ и глубина погружения свай $h_{R}$ были разбиты через 0,5 м с диапазонами:

$$
0,25 \leq 0,5<0,75 \text { м - для } 0,5 \mathrm{M} ; 0,75 \leq 1,0<1,25 \mathrm{M} \text { - для } 1,0 \text { м и т.д. }
$$
$15,75 \leq 16<16,25$ м 16,0 м. 
Для пылевато-глинистых грунтов:

- по показателю текучести $J_{L}$ через 0,1 единицы, т.е.

$0,05<0,0 \leq 0,05$ - для $J_{L}=0,0 ; 0,05<0,5 \leq 0,15$ - для $J_{L}=0,10$ и т.д. $0,05<1,2 \leq 1,25$ - для $J_{L}=1,2$;

- по коэффициенту пористости $е$ через 0,1 единицы, т.е. $0,45<0,5 \leq 0,55$ для е $=0,5 ; 0,55<0,6 \leq 0,65$ - для $\mathrm{e}=0,6$ и т.д. $0,95<1,0 \leq 1,05$ - для е $=1,0$.

Были исключены из дальнейшего рассмотрения за пределами нижеустановленных границ значений $f^{s}$ и $R^{s}$ по параметрам, для которых не удалось установить какие-либо закономерности их изменения, главным образом, из-за недостаточности выборки:

- как для пылевато-глинистых, так и для песчаных грунтов значения $R^{s}$ при глубине погружения свай, $h_{R}<2,75$ м и $h_{R} \geq 16,25$ м, значения $f^{s}$ при средней глубине расположения слоя грунта $h_{f}<0,25$ м и $h_{f} \geq 16,25$ м;

- для пылевато-глинистых грунтов значения $R^{s}$ при показателе текучести $J_{L} \leq-0,05$ и $J_{L}>-1,05$; значения $f^{s}$ при $J_{L} \leq-0,05$ и $J_{L}>-1,25$;

- как значения $R^{s}$, так и значения $f^{s}$ при коэффициенте пористости $e \leq 0,45$ и е $>1,05$.

Исключены также из дальнейшего рассмотрения те значения $f^{s}$ и $R^{s}$, у которых характерные параметры грунтов оказались за пределами рассмотренных в рамках задачи. Это свеженасыпные грунты, просадочные, набухающие грунты и тому подобные специфичные грунты встречающиеся (чередующиеся) в напластованиях с обычными пылевато-глинистыми и песчаными грунтами. Наряду с этим также исключены из дальнейшего рассмотрения значения $R^{s}$ и $f^{s}$ для рыхлых песков из-за малого числа выборки. 
В результате по перечисленным выше причинам исключены 1279 значений $R^{s}$ (из 12970) и 1805 значений $f^{s}$ (из I6195). Оставшиеся к этому моменту для дальнейшей обработки значения $R^{s}$ составили 11691 штук, в том числе 10359 штук - для пылевато-глинистых и 1332 штук - для песчаных грунтов. Значения $f^{s}$ составили 14390 штук из них I3095 штук - для пылеватоглинистых и 1295 штук - для песчаных грунтов.

Оставщаяся совокупность случайных величин $R^{s}$ и $f^{s}$ в предела) каждого выделенного диапазона влияющих факторов были сгруппированы и систематизированы: для каждого конкретного значения показателя текучести и коэффициента пористости пылевато-глинистых грунтов по глубине; для каждого конкретного песка по крупности и плотности сложения по глубине. Были составлены для каждой группы соответствующие таблицы и графики по данным карточек (рис.4), позволяющие проводить дальнейщий статистический анализ.

Всего было составлено I54 таблиц и столько же построено графиков зависимости $R^{s}$ и $f^{s}$ с глубиной. Из них 72 для $R^{s}$ (56 для пылеватоглинистых грунтов и 6 - для песчаных), 82 - для $f^{s}$ (76 - для пылеватоглинистых грунтов и 6 - для песчаных).

Результаты дисперсионного анализа, проведенного для каждого предполагаемого фактора, вызывающего изменчивость случайных величин $R^{s}$ и $f^{s}$, подтвердили правильность группировки, установленной на основании предварительного анализа распределений опытных значений $R^{s}$ и $f^{s}$.

\section{2. Результаты дисперсионного анализа $R^{s}$ и $f^{s}$}

В любом ряде результатов испытаний свай имеется несколько факторов, вызывающих изменчивость средних значений случайных величин $\bar{R}^{s}$ и $\bar{f}^{s}$. 
Эти факторы могут принадлежать ко многим источникам изменчивости. Например, изменчивость $\bar{R}^{s}$ и $\bar{f}^{s}$ можно ожидать в зависимости от вида грунта, его состояния и характеристик физических свойств, от размеров свай, а также от ошибок при испытаниях свай и вычислениях самих значений $\bar{R}^{s}$ и $\bar{f} s$.

Исследование влияния тех или иных факторов на изменчивость средних значений случайных величин $\bar{R}^{s}$ и $\bar{f}^{s}$ можно установить дисперсионным анализом.

Не останавливаясь на технике статистических исчислений стандартного дисперсионного анализа, которая широко освещена в литературе [2, 3 и др.], отметим лишь основные принципы и результаты, полученные этим анализом.

Дисперсионный анализ состоит в выделении и оценке отдельных факторов, вызывающих изменчивость. С этой целью производится разложение дисперсии наблюденной частичной совокупности на составляющие, порождаемые независимыми факторами. Каждая из этих составляющих дает оценку дисперсии в общей совокупности.

Для проверки значимости этих оценок дисперсии сравнивают их с оценкой дисперсии, вызываемой только в силу случайного состава частичной совокупности.

Проверка значимости оценок дисперсии производится при помощи таблиц значений статистики F (так называемого критерия Фишера) [3].

Если наблюдаемое значение статистики $\mathrm{F}$ окажется меньше табличного, то это указывает, что не имеется оснований приписывать какие-либо значения влиянию рассматриваемого фактора на изменчивость средних значений случайной величины $\bar{R}^{s}$ или $\bar{f}^{s}$; если же наблюдаемое значение $\mathrm{F}$ окажется больше табличного, то рассматриваемый фактор влияет на изменчивость средних значений $\bar{R}^{s}$ или $\bar{f}^{s}$. В технических расчетах сравнение обычно 
производится при 5\% - ном уровне значимости $\mathrm{F}$ [3], что принято и в настоящей работе.

После того как при помощи дисперсионного анализа будет произведена оценка влияния каждого фактора и выделяются те, для которых рассматриваемая оценка дисперсии будет признана значимой, необходимо перейти к установлению закономерности изменений $f^{s}$ и $R^{s}$ в зависимости от выделенных факторов, обеспечивая при этом представительность выборки, что дает возможность определить их нормативные и расчетные значения.

В дисперсионном анализе в качестве факторов, вызывающих измечивость средних значений $\bar{f} s$ и $\bar{R} s$, как и при их группировке, были рассмотрены: средняя глубина расположения слоя грунта $h_{f}$ для $\bar{f} s$; глубина погружения свай $h_{R}$ для $\bar{R} s$; размеры поперечного сечения свай $\mathrm{d}$; показатель текучести, коэффициент пористости $J_{L}$, е и наименование глинистых грунтов по числу пластичности;

крупность и плотность сложения песчаных грунтов для обоих величин ( $\bar{R}^{s}$ и $\left.\bar{f}^{s}\right)$.

Результаты дисперсионного анализа лишь подтвердили правильность принятой группировки значений $R^{s}$ и $f^{s}$, где были учтены основные параметры, от которых они зависят. Наиболее значимыми факторами по критерию Фишера, вызывающими изменчивость случайных величин $\bar{R} s$ и $\bar{f}$, оказались:

- для пылевато-глинистых грунтов показатель текучести $J_{L}$ коэффициент пористости е, глубина погружения свай $h_{R}$ (для $\bar{R} s$ ) средняя глубина расположения слоя $h_{f}$ (для $\bar{f} s$ ). 
- для песчаных грунтов вид песков по крупности, плотность их сложения, глубина погружения свай $h_{R}$ (для $\bar{R}^{s}$ ), средняя глубина расположения слоя грунта $h_{f}$ (для $\bar{f}^{s}$ ).

Согласно критерия Фишера, как несущественно влияющие на случайные величины $\bar{R}^{s}$ и $\bar{f}^{s}$ оценивались: размеры поперечного сечения свай, прочностные показатели $\varphi$ и С, модуль общей деформации Е для обоих видов грунта и наименование глинистых грунтов по числу пластичности.

Согласно дисперсионного анализа отсутствие формальной связи между $J_{p}, \mathrm{c}, \varphi$, и значениями $\bar{R} s, \bar{f}$ объясняется не только количественными и качественными недостатками их определений в материалах массовых стандартных испытаний свай, но и, по-видимому, еще и тем, что показатель текучести и коэффициент пористости, являясь более общими характеристиками грунтов косвенно, в определенной степени отражают влияния указанных характеристик. Пожалуй, этим можно объяснить возможность определения значений $\varphi, \mathrm{C}$ и Е, согласно СП по статистически обоснованным таблицам в зависимости от показателя текучести, коэффициента пористости для глинистых грунтов, крупности и плотности сложения для песчаных грунтов.

В отношении размера поперечного сечения следует отметить, что более $60 \%$ значений $R^{s}$ и $f^{s}$ из общего числа определений, соответствовали сваям с поперечным сечением 30х30 см, около 30\% -сечением 35х35cм, остальные $25 \times 25$ см, 40x40 см и другим. Естественно, на фоне большого числа рассматриваемых факторов, столь малое изменение размеров поперечного сечения не позволяет выявить влияние его на изменчивость средних значений $\bar{R} s_{\text {и }} \bar{f}$.

Отметим, что значения $R^{s}$ и $f^{s}$ при установленных наиболее значимых факторах подвергались корреляционному анализу с целью определения их 
нормативных и расчетных значений. При этом, для каждой зависимости $R^{S}$ и $f^{s}$ от наиболее значимых факторов была обеспечена представительность выборки, которая устанавливалась согласно графика, приведенного на рис. 5, при коэффициенте вариации полученном в ходе корреляционного анализа. Окончательная вероятностно-статистическая обработка, подтвердила результаты предварительной обработки, полученной в настоящем работе.

\section{Выводы}

1. На основе сопоставительного анализа результатов стандартных испытаний свай статической нагрузкой разработана методика оценки несущей способности свай по критерию коэффициента статической деформации, которая учитывает величину передаваемой нагрузки, времени ее выдержки под каждой ступенью и величину деформации сваи в период испытаний. Оценка несущей способности свай по предложенной методике исключает возможность получения ее различных значений для одной и той же сваи, что присуще действующим рекомендациям.

2. Разработана методика разделения несущей способности свай на сопротивление острие $R^{S}$ и боковой поверхности $f^{S}$ по результатам параллельных стандартных испытаний статической нагрузкой, которая позволила обеспечить достаточные их выборки для вероятностностатистической обработки с целью установления нормативных и расчетных значений $R$ и $f$.

3. По результатам дисперсионного анализа результатов массовых стандартных испытаний свай статической нагрузкой в водонасыщенных грунтах установлены наиболее значимые факторы, которыми являются глубина погружения для $\bar{R} s$, средняя глубина расположения слоя грунта для $\bar{f} s$, 
показатель текучести и коэффициент пористости пылевато-глинистых грунтов, крупность и плотность сложения песчаных грунтов для величин $\bar{R} s_{\text {и }} \bar{f}$.

4. По результатам массовых стандартных испытаний свай не удалось установить четкие закономерности изменения $\bar{R}^{s}$ и $\bar{f}^{s}$ от изменения размеров поперечного сечения сваи, числа пластичности, степени влажности и прочностных показателей грунта. По статистическим критериям эти факторы оценивались как несущественно влияющие на изменение случайных величин $\bar{R}^{s}$ и $\bar{f}^{s}$.

Более детальный анализ полученных данных позволяет предположить, что отсутствие формальной связи между $\bar{R}^{s}, \bar{f}^{s}$ и указанными выше характеристиками не свидетельствует о том, что число пластичности, степень влажности и прочностные показатели грунта вообще не влияют на несущую способность сваи. По-видимому, это связано с качественными и количественными недостатками определения этих показателей при массовых стандартных испытаниях и с тем, что их влияние в скрытом виде проявляется через показатель текучести и коэффициент пористости пылевато-глинистых грунтов, крупность и плотность сложения песчаных грунтов, с которыми установлена весьма тесная связь.

\section{Список литературы}

1. Луга А.А. К нормам расчетных сопротивлений свай по грунте. /тр ЦНИИС. Вып.56. -1965. - М.: Транспорт. С.105-114.

2. Вентцель Е.С. Теория вероятностей. - М.: Наука. 1969. -576с.

3. Митропольский А.К. Техника статистических вычислений. - М.: Наука, 1971. - 576c.

4. Лапшин Ф.К. Расчет оснований одиночных свай на вертикальную нагрузку. - Дисс. докт. Тех.наук. - М., 1988. - 469c. 
5. Бартоломей А.А. Основы расчета ленточных свайных фундаментов по предельно допустимым осадкам. - М.: Стройиздат, 1982. - 223c.

6. Бахолдин Б.В. Экспериментальные и теоретические исследования процесса взаимодействия грунта с забивными сваями и создание на их основе практических методов расчета свай. - Дисс. докт. техн наук. - М., 1987. - 472c.

7. Ермолаев Н.Н., Михеев В.В. Надежность оснований сооружений. - Л.: Стройиздат, 1976. -152c.

8. Игнатова О.И. Об изменчивости характеристик грунтов оснований зданий и сооруений. /Тр НИИОСП. Вып.68. - М.: Стройиздат, 1977. - С. 78-83.

9. Коваль В.Е. Оперштейн В.Л., Харитон Л.Е. Швец В.Б. О рациональном объеме статических испытаний при проектировании свайных фундаментов. - Основания и фундаменты в геологических условиях Урала. / Межвуз. Сб. научн. Трудов. - Пермь: ППИ, 1983. - С.35-39.

10. Mirsaidov M.M., Sultanov T.Z., Yarashov J.A., Khujanazarova, N., Urazmukhammedova, Z. Mathematical simulation and the methods to assess the strength of earth dams. International Conference on Information Science and Communications Technologies: Applications, Trends and Opportunities, 2019. ICISCT 2019. 9011818.

11. Kubaymurodov D.I., Ismayilov K., Ibragimov A. Application of the Bubnov-Galerkin method to determine the statistical characteristics of the state of a prismatic shell. Prospective research solutions collection of articles of the IIIInternational Scientific and Technical Competition. p. 1131212021 Petrozavodsk https://www.elibrary.ru/item.asp?id=44587093. DOI: 10.46916 / 22012021-3-978-500174-117-6.

12. Ismayilov K. Critical strains and critical stresses in the steel rod beyond the elastic limit. European Science Review. 2018, № № 5-6.

13. Ismayilov K., Karimova K. The Impact of Automobile Tires on the Environment from the Period of Raw Materials to Their Disposal, Retrieval Volume- 


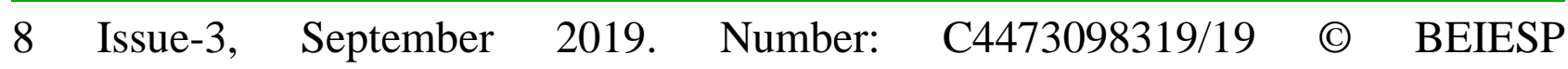
DOI:10.35940/ijrte.C4473.098319.

14. Ismayilov K., Suleymanov A., Toshev S., Ruziev S. Option of the Method of Successive Approximations in Calculating the Epicenters of Extreme and Emergency Situations. Ilkogretim Online - Elementary Education Online, 2021; 20 (3): pp. 1640-1647 http://ilkogretim-online.org doi: 10.17051/ilkonline.2021.03.186.

15. Mavlonov T., Yuldoshev B., Ismayilov K., Toshev S. Compressed rectangular plates stability beyond the elastic limit. IOP Conference Series: Materials Science and Engineering. 2020. DOI:10.1088/1757-899X/883/1/012199.

16. Ismayilov K. Stability of compressed rods, plates and shells beyond the elastic limit. FAN. Samarkand, 2003, p. 280.

17. Ismayilov K., Suleymanov S.T., Ruziev S.T., Aripjanova M.B. A new method of successive approximations when calculating elements of electromechanical machines.XXI Century. Technosphere Safety. 2020; 5(2):168-172. (In Russ.) https://doi.org/10.21285/2500-1582-2020-2-168-172.

18. Ismayilov K. On the stability of a compressed bar beyond elasticity nternational Congress. Spatial structures in new construction during the reconstruction of buildings and structures. MKPK98. Moscow 1998.p.46.

19. Ismayilov K. Stress strain state of a circular plate beyond the elastic limit. Innovative discourse of the development of modern science and technology. Collection of articles of the International Scientific and Practical Conference, held in Petrozavodsk on May 10, 2021. pp. 7-23. DOI 10.46916 / 12052021-1-978-5-00174228-9

20. Kubaymuradov D.I, Mamasoliev K. Calculation of two-layer beam plates lying on a non-uniform foundation. Modern achievements of youth science: a collection of articles of the International Research Competition (May 11, 2021). Petrozavodsk: ICNP "New Science", 2021. - p. 55-66 
21. Ismayilov K. Development of society and science in the digital economy. "Stability of compressed rods, plates and shells beyond the elastic limit" Petrozavodsk ICNP "New Science" Monograph. 2021 200s. ISBN 978-5-00174-2937. DOI 10.46916 / 19082021-1-978-5-00174-293-7.

22. Ismayilov K. Stress-strain state of a circular plate beyond the elastic limit. Innovative discourse of the development of modern science and technology. Collection of articles of the International Scientific and Practical Conference, held in Petrozavodsk on May 10, 2021. pp. 7-23. DOI 10.46916 / 12052021-1-978-5-00174228-9.

23. Ismayilov K., Karimova K. Application of used automobile tires granules for road construction in Uzbekistan. Journal of Critical Reviews, 2020. V.7, No12, pp 946-948. DOI: 10.31838/jcr.07.12.165.

24. Mirsaidov M.M., Sultanov T., Yarashov J., Toshmatov E. Assessment of dynamic behaviour of earth dams taking into account large strains. E3S Web of Conferences, 2019. 97, 05019. 


\title{
УДК 624.04
}

\section{Глава 9. \\ АНТИСИММЕТРИЧНЫЕ КОЛЕБАНИЯ УПРУГОЙ ТРЕХСЛОЙНОЙ ПЛАСТИНКИ}

\author{
Яхшибоев Шерзод Рустамкулович \\ доктор философии (PhD) \\ по физико-математическим наукам \\ Самаркандский государственный \\ архитектурно-строительный институт
}

Аннотация: В работе исследуются антисимметричные (поперечные) колебания упругой трехслойной пластинки. Материалы слоев характеризуются, как упругие и изотропные. При этом считается, что пластинка не симметрична по толщине. Исходя из точных решений уравнений линейной теории упругости в преобразованиях, разработана теория нестационарных поперечных колебаний трехслойной пластинки. Уравнения колебания выведены относительно двух вспомогательных функций, являющимися главными частями продольного и поперечного перемещений точек некоторой «промежуточной» поверхности срединного слоя (заполнителя). Расстояние данной поверхности до координатной плоскости пластинки (срединной плоскости заполнителя) является произвольным. Все компоненты тензоров напряжений и векторов перемещений в точках слоев выражены, как и уравнения колебания, через введенные вспомогательные функции, которые позволяют по полю искомых функций однозначно, с заданной точностью определить полей перемещений и напряжений в произвольном сечении пластинки. Предложены уточненные приближенные уравнения колебания трехслойной пластинки, пригодные для 
решения прикладных задач колебания трехслойных пластин. Решена задача о гармонических антисимметричных колебаниях упругой трехслойной пластинки. Полученные численные результаты представлены в виде графиков зависимостей частоты колебаний от волнового числа для различных материалов как срединного, так и несущих слоев пластинки. При этом расчеты проводились для стальных и алюминиевых несущих слоев и различных материалов (полимер, стеклопластик, древесный пластик, текстолит) для заполнителя. По результатам численных расчетов сделаны соответствующие выводы. Сравнительный анализ численных результатов показал, что предложенные уравнения колебания и алгоритм определения напряженнодеформированного состояния трехслойной пластинки, позволяют с достаточной степенью достоверности определять частоты поперечных ее колебаний.

Ключевые слова: трехслойная пластинка, упругость, колебание, перемещение, напряжение, несущий слой, заполнитель, частота колебаний, волновое число.

\section{ANTISYMMETRICAL OSCILLATION ELASTIC THREE-LAYER PLATE}

\section{Yachshiboyev Sherzod Rustamkulovicg}

Abstract: The article in a flat setting explores antisymmetric (transverse) oscillations of a three-layer plate, which is infinite in terms of The materials of the layers are assumed to be elastic and isotropic. It is believed that the plate is not symmetrical in thickness. Based on the exact solutions of the equations of the linear theory of elasticity in transformations, a theory of unsteady transverse vibrations of a three-layer plate is developed. The oscillation equations are derived with respect to two auxiliary functions, which are the main parts of the longitudinal and transverse 
displacements of the points of a certain "intermediate" surface of the middle layer (aggregate). The distance of this surface to the coordinate plane of the plate (the median plane of the filler) is arbitrary. All components of the stress tensors and displacement vectors at the points of the layers are expressed, as well as the oscillation equations, through the introduced auxiliary functions, which allow us to uniquely, with a given accuracy determine the displacement and stress fields in an arbitrary section of the plate using the field of unknown functions. Refined approximate equations of vibration of a three-layer plate are proposed, which are suitable for solving applied problems of vibration of a three-layer plate. The problem of harmonic antisymmetric oscillations of an elastic three-layer plate is solved. The obtained numerical results are presented in the form of graphs of the dependences of the oscillation frequency on the wave number for various materials of both the middle and the bearing layers of the plate. The calculations were carried out for steel and aluminum bearing layers and various materials (polymer, fiberglass, wood plastic, textolite) for the aggregate. According to the results of numerical calculations, the corresponding conclusions are made. A comparative analysis of the numerical results showed that the proposed oscillation equations and the algorithm for determining the stress-strain state of a three-layer plate make it possible to determine the frequencies of its transverse vibrations with a sufficient degree of reliability.

Key words: three-layer plate, elasticity, oscillation, displacement, stress, carrier layer, aggregate, oscillation frequency, wave number.

\section{1. Введение}

Многослойные пластины и оболочки нашли широкое применение в различных областях техники. Сфера применения трехслойных пластин чрезвычайна широка. Она включает в себя такие области, как строительство, авиастроение, приборостроение и др. Поэтому, расчет таких пластин на 


\section{СТРАТЕГИЯ НАУЧНО-ТЕХНОЛОГИЧЕСКОГО РАЗВИТИЯ РОССИИ: ПРОБЛЕМЫ И ПЕРСПЕКТИВЫ РЕАЛИЗАЦИИ}

действие различных динамических нагрузок находят широкое применение в проектировании и эксплуатации инженерных конструкций, работающих зачастую в экстремальных условиях на действия взрывных, сейсмических и других нагрузок [1].

Трехслойные структуры, появление которых было продиктовано потребностями, в первую очередь, в военной области, полностью удовлетворяли требованиям по сочетанию механических характеристик материалов и функциональных требований, предъявляемым к инженерным конструкциям. Условия интенсивного использования трехслойных и многослойных структур способствовали необходимости разработки эффективных методов расчета таких элементов [2]. Поэтому, одновременно с началом применения многослойных структур начали развиваться и теории их расчета.

Первенство в построении теории расчета многослойных пластин принадлежит С.Г. Лехницкому, который создал теорию, впоследствие названной «зиг-заг» теорией [3]. В этом плане для анализа многослойных композитных слоистых пластин Z.G. Renom представлено предположение, основанное на теории композитных балок. По этому предположению плоскостные смещения и поперечные касательные напряжения между слоями являются непрерывными. Получены уравнения равновесия и граничные условия, аналогичные классической «зиг-заг» теории пластин [4].

Использование и уточнение теории «зиг-заг» продолжается и в наши дни, о чем свидетельствуют многочисленные исследования [5]. Например, в работе K.H. Lee [6] предложена улучшенная зигзагообразная модель, основанная на послойной кубической вариации смещений в плоскости и параболической вариации поперечных сдвиговых напряжений с нулевыми значениями на свободных поверхностях. Предложенная модель зигзагообразного смещения использована для описания поведения многослойных композитных пластин, 
подвергнутых двунаправленному изгибу. При выполнении условий непрерывности смещений в плоскости и поперечных сдвиговых напряжений на границах раздела показано, что число переменных такое же, как и в теории деформации сдвига первого порядка Миндлина.

Как обобщение теории Рейсснера-Миндлина на слоистые анизотропные пластины С.А. Амбарцумяном [7] была предложена теория изгиба анизотропных пластин, основанная на учете деформации сдвига. Разработке сдвиговой теории расчета трехслойных пластин посвящено большое количество исследований. В этих работах приведены уточненные модели и новые теории, основанные тем или иным способом и учитывающие сдвиговую деформацию.

Разработке новой теории деформации сдвига для многослойных и композитных плит посвящена работа [8]. Поле смещений аппроксимируется с помощью произведения тригонометрических и экспоненциальных функций. Теория учитывает адекватное распределение поперечных деформаций сдвига по толщине пластинки и тангенциальных граничных условий без напряжений на граничной поверхности. Аналогичному представлению сдвиговой деформации с помощью экспоненциальной функции в поле перемещений посвящена статья [9]. В ней представлена новая модель многослойной композитной структуры, которая описывает распределения напряжения сдвига по толщине с учетом условий свободной границы на верхней и нижней поверхностях с помощью экспоненциальной функции.

Можно привести множество научных работ, посвященных созданию моделей, где учет деформации осуществляется привлечением некоторых функций гиперболического [10], степенного [11] и смешанного гиперболического с иррациональной [12] типов. Сюда же примыкает новая теория сдвига высшего порядка и нормальной деформации [13] для анализа изгиба и свободных колебаний многослойных пластин с функционально 
градиентными изотропными лицевыми пластинами. Разработана также модель [14] $n$-го порядка для сдвиговой деформации для расчета функционально градуированной и композитной многослойной пластины. Предложенная теория, как частный случай, допускает получение теорию Reddy третьего порядка. Послойная теория Reddy была использована для анализа свободных колебаний ламинарных пластин также в [15].

Количество опубликованных исследований, посвященных разработке новых моделей и теорий нестационарного колебания, трехслойных и многослойных пластин и оболочек, подвергнутых воздействию внешних динамических нагрузок, малы по сравнению со случаем статики. Данные работы основаны на методе общих решений в преобразованиях, которые используются для удовлетворения условий, заданных на поверхностях пластин и оболочек. Логическим продолжением этих исследований являются исследования, в которых предложены новые математические модели нестационарных колебаний пластин и оболочек, исходя из точного решения соответствующих трехмерных задач вязкоупругости. Разработанные в этих работах методы разработки теории колебаний пластин и оболочек применены затем для исследования слоистых конструкций [20-32].

Анализ большого числа опубликованных работ по колебаниям слоистых пластин показывает, что наиболее изученными являются изгибные колебания. Эти исследования продолжаются и в настоящее время. Вместе с тем изучение исследований по нестационарным колебаниям трехслойных пластин с учетом новых требований современной техники, позволяет сделать вывод о том, что остается ещё много проблем, далеких от своего решения и поэтому, новые исследования в этом направлении актуальны. 


\section{2. Постановка задачи}

Рассмотрим трехслойную, бесконечную в плане, упругую пластинку. Будем считать, что пластинка состоит из двух несущих слоев с толщинами $h_{1}$ и $h_{2}$ и срединного слоя толщиной $2 h_{0}$ (Рис.1).

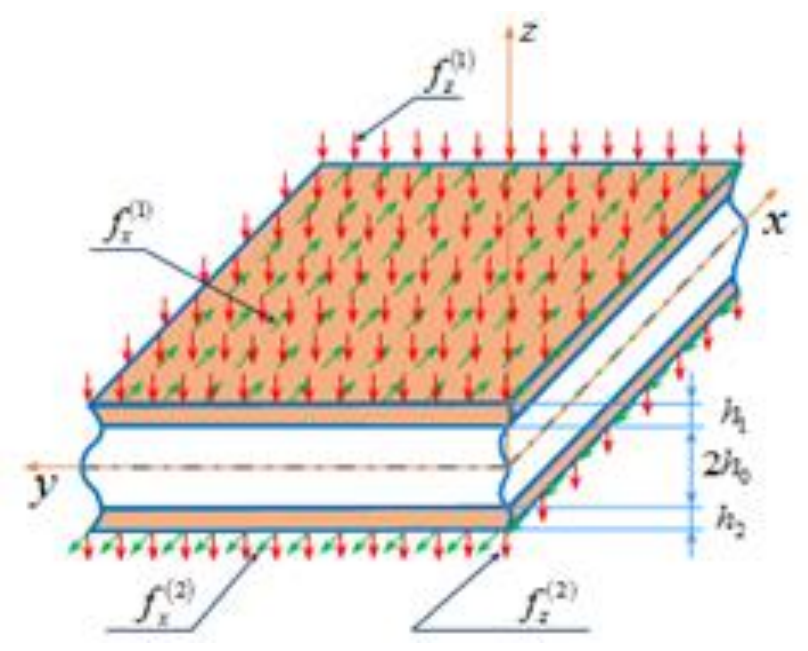

Рис. 1. Геометрия трехслойной пластинки

В том случае, когда пространство между несущими слоями заполнено более легким, т.е. менее жестким материалом, срединный слой называется заполнителем. При выводе уравнений колебания будем считать, что как пластинка в целом, так и каждый ее слой в отдельности строго подчиняются математической линейной теории упругости и в точной постановке описываются трехмерными ее уравнениями.

Учитывая неограниченность размеров пластинки, в дальнейшем будем считать, что она находится в условиях плоской деформации. Поэтому, пластинку будем рассматривать в системе прямоугольных координат охz и направим ось $O x$ по срединной линии поперечного сечения, а ось $O z-$ вверх, перпендикулярно оси $O x$. Несущие слои пластинки назовем первым и вторым (в соответствии с их толщинами $h_{1}$ и $h_{2}$ ) слоями, а срединный слой нулевым. 
Зависимости напряжений от деформаций в точках изотропных слоев пластинки описываются линейным законом Гука.

В случае плоской деформации перемещения точек слоев равны [26]

$$
\vec{U}^{m}=U_{m} \vec{i}+W_{m} \vec{k}, \quad U_{m}=U_{m}(x, z, t), \quad W_{m}=W_{m}(x, z, t), \quad(m=0,1,2),
$$

где $\vec{i}, \vec{k}$ - единичные векторы осей координат. В этом случае введением компонент векторов перемещений по формулам [27]

$$
U_{m}=\frac{\partial \varphi_{m}}{\partial x}-\frac{\partial \psi_{m}}{\partial z}, \quad W_{m}=\frac{\partial \varphi_{m}}{\partial z}+\frac{\partial \psi_{m}}{\partial x},(m=0,1,2)
$$

уравнения движения точек составляющих пластинку слоев в декартовой системе легко привести к волновым уравнениям

$$
\left(\lambda_{m}+2 \mu_{m}\right)\left(\Delta \varphi_{m}\right)=\rho_{m} \ddot{\varphi}_{m} ; \quad \mu_{m}\left(\Delta \psi_{m}\right)=\rho_{m} \ddot{\psi}_{m},
$$

здесь $\lambda_{m}, \mu_{m}, \rho_{m}(m=0,1,2)$ - упругие коэффициенты (Ламе) и объемные плотности слоев; $\varphi_{m}$ и $\psi_{m}$ - некоторые потенциальные функции, подлежащие определению; $\Delta$-двухмерный оператор Лапласа.

Поперечные колебания пластинки возбуждаются при граничных условиях

$$
\left.\sigma_{z z}\right|_{z= \pm h_{i}^{*}}= \pm f_{1}(x, t) ;\left.\tau_{x z}\right|_{z= \pm h_{i}^{*}}=f_{2}(x, t) ;\left.\tau_{x z}\right|_{z= \pm h_{i}^{*}}=0 \quad h_{i}^{*}=h_{0}+h_{i},(i=1,2)
$$

где функции $f_{1}(x, t)$ и $f_{2}(x, t)$ антисимметричные части функции внешних динамических нагрузок. Кроме того, на поверхностях срединного слоя, при $z= \pm h_{0}$ должны выполнятся следующие динамические и кинематические условия

$$
\sigma_{z z}^{(0)}=\sigma_{z z}^{(i)}, \quad \tau_{x z}^{(0)}=\tau_{x z}^{(i)}, \quad \tau_{y z}^{(0)}=0
$$

и

$$
u_{0}=u_{i}, \quad w_{0}=w_{i}, \quad i=\left\{\begin{array}{l}
1, \text { при } z=h_{0} \\
2, \text { при } z=-h_{0}
\end{array} .\right.
$$

Начальные условия задачи считаются нулевыми.

При задании компонент перемещений в виде (2.1) напряжения задаются выражениями 


$$
\begin{aligned}
& \sigma_{x x}^{(m)}=\lambda_{m}\left(\Delta \varphi_{m}\right)+2 \mu_{m}\left(\frac{\partial^{2} \varphi_{m}}{\partial x^{2}}-\frac{\partial^{2} \psi_{m}}{\partial x \partial z}\right) \\
& \sigma_{z z}^{(m)}=\lambda_{m}\left(\Delta \varphi_{m}\right)+2 \mu_{m}\left(\frac{\partial^{2} \varphi_{m}}{\partial x^{2}}+\frac{\partial^{2} \psi_{m}}{\partial x \partial z}\right) \\
& \sigma_{x z}^{(m)}=\mu_{m}\left(2 \frac{\partial^{2} \varphi_{m}}{\partial x \partial z}-\frac{\partial^{2} \psi_{m}}{\partial z^{2}}+\frac{\partial^{2} \psi_{m}}{\partial x^{2}}\right)
\end{aligned}
$$

\section{3. Уравнения колебания трехслойной пластинки}

Для решения поставленной задачи функции внешних воздействий из (2.3) представим в виде:

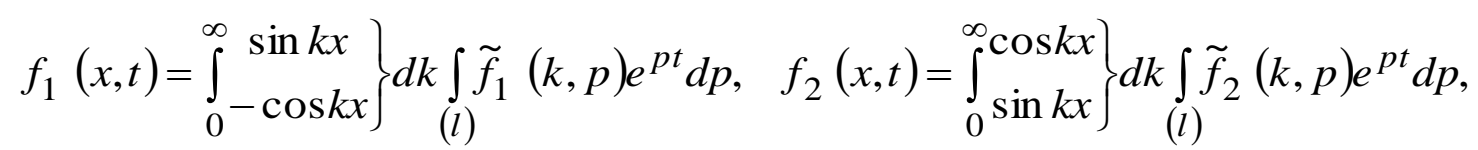

где $\tilde{f}_{1}(k, p), \quad \tilde{f}_{2}(k, p)$ - функции, регулярные при $\operatorname{Re} p \geq 0$, имеющие конечное число полюсов, принимающие произвольные значения внутри некоторой области $\Omega(k, p)$, содержащий промежуток $\left(-i \omega_{0}, i \omega_{0}\right)$ мнимой оси, убывающие при $p \rightarrow \mp i \infty$ не медленнее, чем $|p|^{-n_{0}}$, где $n_{0}>>1$, и такие, что вне $\Omega(k, p)$ их значения пренебрежимо малы. Кроме того функции $\tilde{f}_{1}(k, p)$ и $\tilde{f}_{2}(k, p)$ - аналитические, принимающие произвольные значения в промежутки $\left(0, k_{0}\right)$, убывающие при $k \rightarrow \infty$, как $k^{-n_{0}}$, и пренебрежимо малые при $k>k_{0} ;(l)$ -контур $\operatorname{Re} p=v>0$ на комплексной плоскости $(p)$, оставляющего область $\Omega(k, p)$ правее себя.

В соответствии с принятыми представлениями для функции внешних воздействий потенциальные функции $\varphi_{m}(x, z, t)$ и $\psi_{m}(x, z, t)$ также представим в виде (3.1), подстановка которых в (2.2) дает обыкновенные дифференциальные 
уравнения Бесселя относительно преобразованных по (3.1) функций $\tilde{\varphi}_{m}(z, k, p)$ и $\tilde{\psi}_{m}(z, k, p)$

$$
\frac{d^{2} \tilde{\varphi}_{m}}{d z^{2}}-\alpha_{m}^{2} \tilde{\varphi}_{m}=0, \quad \frac{d^{2} \tilde{\psi}_{m}}{d z^{2}}-\beta_{m}^{2} \tilde{\psi}_{m}=0,(m=0,1,2)
$$

где $\alpha_{m}^{2}=k^{2}+\rho_{m} p^{2}\left(\lambda_{m}+2 \mu_{m}\right)^{-1} ; \quad \beta_{m}^{2}=k^{2}+\rho_{m} p^{2} \mu_{m}^{-1} ; \arg \alpha=\arg \beta=0$, при $\rho>0$

Решения уравнений (3.2) в случае поперечных колебаний пластинки, с учетом антисимметричности воздействий в граничных условиях (2.3), будут

$$
\tilde{\varphi}_{m}(z, k, p)=A_{m}^{(2)}(k, p) \operatorname{sh}\left(\alpha_{m} z\right) ; \tilde{\psi}_{m}(z, k, p)=B_{m}^{(2)}(k, p) \operatorname{ch}\left(\beta_{m} z\right),(m=0,1,2) .
$$

Перемещения $U_{m}$ и $W_{m}$ также представим в виде (3.1), подставляя которых вместе с представлениями потенциальных функций в выражение перемещений (2.1), для преобразованных функций $\tilde{U}_{m}$ и $\tilde{W}_{m}$ будем иметь

$$
\tilde{U}_{m}=k \tilde{\varphi}_{m}-\frac{\partial}{\partial z} \tilde{\psi}_{m}, \tilde{W}_{m}=\frac{\partial}{\partial z} \tilde{\varphi}_{m}-k \tilde{\psi}_{m} .
$$

Выразив преобразованные перемещения $\tilde{U}_{m}$ и $\tilde{W}_{m}$ через решения (3.3) разложим в них в степенные ряды гиперболические функции. Далее в качестве искомых функций примем главные части преобразованных перемещений $\tilde{U}_{0}$ и $\tilde{W}_{0}$ такой поверхности срединного слоя пластинки, расстояние от поверхности $z=0$ которой равно $\xi \neq 0$, где $\xi=c o n s t$ число, удовлетворяющее неравенству $-h_{o} \leq \xi \leq h_{o}$. Для этого в упомянутых разложениях ограничимся нулевым приближением и примем $z=\xi$ и $m=0$. Тогда введя обозначения $\tilde{U}_{0}^{(0)}$ и $\tilde{W}_{0}^{(0)}$ для главных частей преобразованных перемещений получим

$$
\left(\beta_{0}^{2}-k^{2}\right) B_{0}^{(2)}=k \widetilde{W}_{0}^{(0)}-\frac{1}{\xi} \widetilde{U}_{0}^{(0)} ; \quad \alpha_{0}\left(\beta_{0}^{2}-k^{2}\right) A_{0}^{(2)}=\beta_{0}^{2} \widetilde{W}_{0}^{(0)}-\frac{k}{\xi} \widetilde{U}_{0}^{(0)} .
$$

Подставляя (3.4) в разложения преобразованных перемещений при $m=0$ получим 


$$
\left.\begin{array}{l}
\left.\tilde{U}_{0}=\sum_{n=0}^{\infty}\left[k q_{0} Q_{0}^{(n)}\left(\frac{k}{\xi} \tilde{U}_{0}^{(0)}-\beta_{0}^{2} \tilde{W}_{0}^{(0)}\right)-\frac{\beta_{0}^{2 n}}{\xi} \tilde{U}_{0}^{(0)}\right] \frac{z^{2 n+1}}{(2 n+1) !}\right], \quad-h_{0} \leq z \leq h_{0}, \\
\tilde{W}_{0}=\sum_{n=0}^{\infty}\left[q_{0} Q_{0}^{(n)}\left(\frac{k}{\xi} \tilde{U}_{0}^{(0)}-\beta_{0}^{2} \tilde{W}_{0}^{(0)}\right)+\beta_{0}^{2 n} \tilde{W}_{0}^{(0)}\right] \frac{z^{2 n}}{(2 n) !}
\end{array}\right\}, \quad
$$

где $Q_{m}^{(n)}=\left(\alpha_{m}^{2 n}-\beta_{m}^{2 n}\right) /\left(\alpha_{m}^{2}-\beta_{m}^{2}\right), Q_{m}^{(0)}=0, \quad Q_{m}^{(1)}=1, \quad Q_{m}^{(2)}=\alpha_{m}^{2}+\beta_{m}^{2}, \quad m=0,1,2$; $q_{m}=1-L_{m} M_{m}^{-1}$

Подставляя решения (3.3) в контактные условия (2.5), при $z=h_{0}$ получим уравнения

$$
\begin{aligned}
& k A_{0}^{(2)} \operatorname{sh} \alpha_{0} h_{0}-\beta_{0} B_{0}^{(2)} \operatorname{sh} \beta_{0} h_{0}=k A_{1}^{(2)} \operatorname{sh} \alpha_{1} h_{0}-\beta_{1} B_{1}^{(2)} \operatorname{sh} \beta_{1} h_{0}, \\
& \alpha_{0} A_{0}^{(2)} \operatorname{ch} \alpha_{0} h_{0}-k B_{0}^{(2)} \operatorname{ch} \beta_{0} h_{0}=\alpha_{1} A_{1}^{(2)} \operatorname{ch} \alpha_{1} h_{0}-k B_{1}^{(2)} \operatorname{ch} \beta_{1} h_{0},
\end{aligned}
$$

которые составляют систему двух алгебраических уравнений относительно двух неизвестных $A_{1}^{(2)}$ и $B_{1}^{(2)}$. Решив эту систему, будем иметь

$$
\begin{aligned}
& A_{1}^{(2)}=\frac{1}{\left(\beta_{0}^{2}-k^{2}\right) \Delta_{1}^{0}}\left[\left(\frac{\beta_{0}^{2}}{\alpha_{0}} \Delta_{11}^{0}+k \Delta_{12}^{0}\right) \tilde{W}_{0}^{(0)}-\frac{1}{\xi}\left(\frac{k}{\alpha_{0}} \Delta_{11}^{0}+\Delta_{12}^{0}\right) \tilde{U}_{0}^{(0)}\right], \\
& B_{1}^{(2)}=\frac{1}{\left(\beta_{0}^{2}-k^{2}\right) \Delta_{1}^{0}}\left[\left(\frac{\beta_{0}^{2}}{\alpha_{0}} \Delta_{21}^{0}+k \Delta_{22}^{0}\right) \tilde{W}_{0}^{(1)}-\frac{1}{\xi}\left(\frac{k}{\alpha_{0}} \Delta_{21}^{0}+\Delta_{22}^{0}\right) \tilde{U}_{0}^{(0)}\right],
\end{aligned}
$$

где

$$
\begin{aligned}
& \Delta_{11}^{0}=\alpha_{0} \beta_{1} \operatorname{sh}\left(\beta_{1} h_{0}\right) \operatorname{ch}\left(\alpha_{0} h_{0}\right)-k^{2} \operatorname{sh}\left(\alpha_{0} h_{0}\right) \operatorname{ch}\left(\beta_{1} h_{0}\right) ; \\
& \Delta_{12}^{0}=k\left[\beta_{0} \operatorname{sh}\left(\beta_{0} h_{0}\right) \operatorname{ch}\left(\beta_{1} h_{0}\right)-\beta_{1} \operatorname{sh}\left(\beta_{1} h_{0}\right) \operatorname{ch}\left(\beta_{0} h_{0}\right)\right] ; \\
& \Delta_{21}^{0}=k\left[\alpha_{0} \operatorname{ch}\left(\alpha_{0} h_{0}\right) \operatorname{sh}\left(\alpha_{1} h_{0}\right)-\alpha_{1} \operatorname{sh}\left(\alpha_{0} h_{0}\right) \operatorname{ch}\left(\alpha_{1} h_{0}\right)\right] ; \\
& \Delta_{22}^{0}=\alpha_{1} \beta_{0} \operatorname{sh}\left(\beta_{0} h_{0}\right) \operatorname{ch}\left(\alpha_{1} h_{0}\right)-k^{2} \operatorname{sh}\left(\alpha_{1} h_{0}\right) \operatorname{ch}\left(\beta_{0} h_{0}\right) ; \\
& \Delta_{1}^{0}=\alpha_{1} \beta_{1} \operatorname{sh}\left(\beta_{1} h_{0}\right) \operatorname{ch}\left(\alpha_{1} h_{0}\right)-k^{2} \operatorname{sh}\left(\alpha_{1} h_{0}\right) \operatorname{ch}\left(\beta_{1} h_{0}\right) .
\end{aligned}
$$

С другой стороны, подставляя решения (3.3) в контактные условия (2.5) при $z=-h_{0}$, находим $A_{2}^{(2)}, B_{2}^{(2)}$. Представим напряжения $\sigma_{x z}^{(m)}$, также как (3.1). Тогда для, преобразованных величин $\tilde{\sigma}_{x z}^{(m)}$ в соответствии с формулами для напряжений (2.6) будем иметь 


$$
\begin{gathered}
\tilde{\sigma}_{x z}^{(m)}(z, k, p)=M_{m}\left[\left(2 k \frac{\partial}{\partial z} \tilde{\varphi}_{m}(z, k, p)-\frac{\partial^{2}}{\partial z^{2}} \widetilde{\psi}_{m}(z, k, p)-k^{2} \widetilde{\psi}_{m}(z, k, p)\right)\right], \\
\tilde{\sigma}_{z z}^{(m)}(z, k, p)=L_{1 m}\left(-k^{2} \widetilde{\varphi}_{m}(z, k, p)+\frac{\partial^{2}}{\partial z^{2}} \tilde{\varphi}_{m}(z, k, p)\right)+2 M_{m}\left(\frac{\partial^{2}}{\partial z^{2}} \tilde{\varphi}_{m}(z, k, p)-k \frac{\partial}{\partial z} \tilde{\psi}_{m}(z, k, p)\right) .
\end{gathered}
$$

С учетом (3.7) и (3.1) граничные условия (2.3) можно записать как

$$
\begin{gathered}
\mu_{m}\left(2 k \alpha_{m} A_{m}^{(2)} \operatorname{ch}\left(\alpha_{m} h\right)-\left(\beta_{m}^{2}+k^{2}\right) B_{m}^{(2)} \operatorname{ch}\left(\beta_{m} h\right)\right)=\tilde{f}_{2}(k, p), \\
\left(\lambda_{m}+2 \mu_{m}\right)\left(\alpha_{m}^{2}-k^{2}\right) A_{m}^{(2)} \operatorname{sh}\left(\alpha_{m} h\right)+2 \mu_{m}\left(\alpha_{m}^{2} A_{m}^{(2)} \operatorname{sh}\left(\alpha_{m} h\right)-k \beta_{m} B_{m}^{(2)} \operatorname{sh}\left(\beta_{m} h\right)\right)=\tilde{f}_{1}(k, p), \\
h_{i}^{*}=h_{0}+h_{i},(i=1,2) .
\end{gathered}
$$

В первом уравнении системы (3.8) положим $m=1$, а во втором $m=2$. Получим

$$
\begin{gathered}
\mu_{1}\left(2 k \alpha_{1} A_{1}^{(2)} \operatorname{ch}\left(\alpha_{1}\left(h_{0}+h_{1}\right)\right)-\left(\beta_{1}^{2}+k^{2}\right) B_{1}^{(2)} \operatorname{ch}\left(\beta_{1}\left(h_{0}+h_{1}\right)\right)\right)=\tilde{f}_{2}(k, p) ; \\
\left(\lambda_{2}+2 \mu_{2}\right)\left(\alpha_{2}^{2}-k^{2}\right) A_{2}^{(2)} \operatorname{sh}\left(\alpha_{2}\left(h_{0}+h_{2}\right)\right)+2 \mu_{2}\left(\alpha_{2}^{2} A_{2}^{(2)} \operatorname{sh}\left(\alpha_{2} z\right)-k \beta_{2} B_{2}^{(2)} \operatorname{sh}\left(\beta_{2}\left(h_{0}+h_{2}\right)\right)\right)=\tilde{f}_{1}(k, p) .
\end{gathered}
$$

Подставляя вқражения постоянные $A_{1}^{(2)}, B_{1}^{(2)} A_{2}^{(2)}, B_{2}^{(2)}$ в (3.9) и разлагая в ряды тригонометрические функции, в левых частях (3.9) по степеням координаты $z$ и обратив, полученных таким образом систему уравнений, будем иметь общие уравнения поперечных колебаний трехслойной пластинки. Эти уравнения имеют бесконечно высокие порядки по производным. Будем считать, что выполнены условия усечения бесконечных рядов, указанных в работе [29] и будем ограничиваться нулевым или первым приближениями в разложениях. В результате получим приближенные уравнения колебания трехслойной пластинки, для решения прикладных задач, в которых переходя к безразмерным переменным по формулам $b_{0} t=t^{*} l, U_{0}^{(0)}=U_{0}^{*} l, \quad W_{0}^{(0)}=W_{0}^{*} h_{0}$, $z=z^{*} h_{0}, x=x^{*} l, \xi=\xi^{*} h_{0}, h_{1}=h_{1}^{*} h_{0}, h_{2}=h_{2}^{*} h_{0}$ получим уравнения: 


$$
\begin{aligned}
& \frac{\left(1+h_{1}\right) h_{0}^{2}}{l^{2}}\left(\frac{\partial^{2}}{\partial t^{2}}-\frac{\partial^{2}}{\partial x^{2}}\right) \frac{\partial^{2} W_{0}^{(0)}}{\partial t^{2}}-\frac{h_{0}^{2}}{6 \xi l^{2}}\left\{\left[\left(2-\frac{b_{0}^{2}}{a_{0}^{2}}\right) \frac{\partial^{2}}{\partial t^{2}}+\left(1+2 q_{0}\right) \frac{\partial^{2}}{\partial x^{2}}+\frac{6 l_{0}^{2}}{h_{0}^{2}}\right] \frac{\partial^{2}}{\partial t^{2}}+8 q_{1}\left(1+h_{1}\right)^{2} \frac{\partial^{4}}{\partial x^{4}}\right\} \frac{\partial U_{0}^{(0)}}{\partial x}= \\
& \frac{h_{0}^{2}}{6 \xi l^{2}}\left\{\left[\left(2-\frac{b_{0}^{2}}{a_{0}^{2}}\right) \frac{\partial^{2}}{\partial t^{2}}+\left(1+2 q_{0}\right) \frac{\partial^{2}}{\partial x^{2}}+\frac{6 l_{0}^{2}}{h_{0}^{2}}\right] \frac{\partial^{2}}{\partial t^{2}}+8 q_{1}\left(1+h_{1}\right)^{2} \frac{\partial^{4}}{\partial x^{4}}\right\} \frac{\partial U_{0}^{(0)}}{\partial x}= \\
& =\frac{\partial^{2} f_{1}^{(2)}}{\partial t^{2}}+\frac{4 h_{0}^{2}}{3 l^{2}} \frac{b_{1}^{2}}{b_{0}^{2}} q_{1}\left(1+h_{1}\right)^{3} \frac{\partial^{4} f_{1}^{(1)}}{\partial x^{4}}+\left(1+h_{1}\right) \frac{\partial^{2} f_{1}^{(1)}}{\partial t^{2}}, \\
& \frac{\left(1+h_{2}\right) h_{0}^{2}}{l^{2}}\left\{\left[\left(1-2 q_{0}\right)\left(\frac{\partial^{2}}{\partial t^{2}}-\frac{\partial^{2}}{\partial x^{2}}\right)+\frac{2 l^{2}}{h_{0}^{2}}\right] \frac{\partial^{2}}{\partial t^{2}}+\frac{8 b_{2}^{2} q_{2}\left(1+h_{2}\right)^{2}}{3 b_{0}^{2}} \frac{\partial^{4}}{\partial x^{4}}\right\} \frac{\partial W_{0}^{(0)}}{\partial x}+ \\
& +\frac{1}{2 \xi}\left\{\left[\frac{\partial^{2}}{\partial t^{2}}-\left(1-2 q_{0}\right) \frac{\partial^{2}}{\partial x^{2}}+\frac{2 l^{2}}{h_{0}^{2}}\right] \frac{\partial^{2}}{\partial t^{2}}+\frac{8 b_{2}^{2} q_{2}\left(1+h_{2}\right)^{2}}{3 b_{0}^{2}} \frac{\partial^{4}}{\partial x^{4}}\right\} U_{0}^{(0)}= \\
& +\frac{2 l}{h_{0}}\left(1+h_{2}\right) \frac{\partial^{2} f_{2}^{(2)}}{\partial t^{2}}+q_{2} h_{2}\left(2+h_{2}\right)\left(\frac{\partial^{2}}{\partial t^{2}}-\frac{b_{2}^{2}}{b_{0}^{2}} \frac{\partial^{2}}{\partial x^{2}}\right) \frac{\partial f_{1}^{(2)}}{\partial x},
\end{aligned}
$$

где $a_{0}$-скорость продольных волн в материале срединного слоя; $b_{0}, b_{1}, b_{2}$-скорости поперечных волн в материалах слоев; а $l$ - длина пластинки.

\section{4. Напряженно-деформированное состояние пластинки}

Наряду с уравнениями колебания выведены формулы для всех компонент тензоров напряжений и векторов перемещений в точках всех трех слоев пластинки. Например, выражения для перемещений $U_{0}$ и $W_{0}$, а также напряжения $\sigma_{\mathrm{xz}}^{(0)}$ в точках срединного слоя, соответствующие степени уравнений колебания (3.10) имеют вид

$$
U_{0}=\frac{z^{3}}{6}\left\{\zeta\left(-q_{0} \frac{\partial}{\partial x} W_{0}^{(0)}+\frac{1}{\xi} U_{0}^{(0)}\right)+\frac{1}{\xi}\left[-q_{0} \frac{\partial^{2}}{\partial x^{2}}+1\right] U_{0}^{(0)}\right\}
$$

здесь $\zeta=\frac{1}{b_{0}^{2}} \frac{\partial^{2}}{\partial t^{2}}-\frac{\partial^{2}}{\partial x^{2}}$, 


$$
\begin{gathered}
W_{0}=\left\{1+\frac{z^{2}}{2}\left(1-q_{0}\right) \zeta+\frac{z^{4}}{24}\left[\frac{\left(1-q_{0}\right)}{a_{0}^{2} b_{0}^{2}} \frac{\partial^{4}}{\partial t^{4}}-\left(\frac{\left(1-2 q_{0}\right)}{b_{0}^{2}}+\frac{\left(1-q_{0}\right)}{a_{0}^{2}}\right) \frac{\partial^{4}}{\partial t^{2} \partial x^{2}}+\left(1-2 q_{0}\right) \frac{\partial^{4}}{\partial x^{4}}\right]\right\} W_{0}^{(0)}- \\
-\frac{1}{\xi}\left\{\frac{z^{2}}{2} q_{0}+\frac{z^{4}}{24} q_{0}\left[\left(\frac{1}{b_{0}^{2}}+\frac{1}{a_{0}^{2}}\right) \frac{\partial^{2}}{\partial t^{2}}-2 \frac{\partial^{2}}{\partial x^{2}}\right]\right) \frac{\partial}{\partial x} U_{0}^{(0)} . \\
\sigma_{\mathrm{xz}}^{(0)}==\mu_{0}\left\{\left[1+\frac{\left(1-2 q_{0}\right)}{2 b_{0}^{2}} z^{2} \zeta\right] \frac{\partial}{\partial x} W_{0}^{(0)}+\frac{1}{\xi}\left[1+\frac{z^{2}}{2}\left(\frac{1}{b_{0}^{2}} \frac{\partial^{2}}{\partial t^{2}}-\left(1+2 q_{0}\right) \frac{\partial^{2}}{\partial x^{2}}\right)\right] U_{0}^{(0)}\right\}
\end{gathered}
$$

Аналогичные виды имеют и выражения для напряжений $\sigma_{\mathrm{zz}}^{(0)}$ и $\sigma_{\mathrm{xx}}^{(0)}$. Вывод формул для перемещений и напряжений в точках верхнего и нижнего несущих слоев также не составляет большого труда, но имеют более громоздкие виды. Поэтому, для примера приводим эти формулы в операторном виде для перемещений $U_{1}$ и $W_{1}$, а также для напряжения $\sigma_{\mathrm{XZ}}^{(1)}$, которые имеют вид

$$
\begin{gathered}
W_{1}=L_{w}^{-1}\left(N_{1} W_{0}^{(0)}+N_{2} \frac{\partial U_{0}^{(0)}}{\partial x}\right) U_{1}, U_{1}=L_{u}^{-1}\left(M_{1} \frac{\partial W_{0}^{(0)}}{\partial x}+M_{2} U_{0}^{(0)}\right) \\
\sigma_{\mathrm{xz}}^{(1)}=\mu_{1} L_{\sigma 1}^{-1}\left(R_{1} \frac{\partial W_{0}^{(0)}}{\partial x}+R_{2} U_{0}^{(0)}\right)
\end{gathered}
$$

где $L_{w}, L_{u}, L_{\sigma}$-линейные дифференциальные операторы четвертого порядка; через $L_{k}^{-1}$ обозначен оператор обратный оператору $L_{k} ; N_{i}, M_{i}, R_{i}$-также линейные дифференциальные операторы не выше четвертого порядка.

Приведенные выражения для компонент напряжений и перемещений (4.1) и (4.2) позволяют определить напряженно-деформированное состояние произвольной точки трехслойной пластинки по главным частям $W_{0}^{(0)}$ и $U_{0}^{(0)}$ по результатам решения дифференциальных уравнений (3.10). 


\section{5. Гармонические колебания трехслойной пластины}

В качестве примера рассмотрим задачу об антисимметричных (поперечных) гармонических колебаниях трехслойной пластины на основе полученных приближенных уравнений колебания. При этом следует считать, что поверхности пластинки свободны от внешних нагрузок. Тогда правые части уравнений колебания (3.10) будут равны нулю. Решение дифференциальных уравнений (3.10) с нулевыми правыми частями будем искать в виде

$$
W_{0}^{(0)}=\bar{W}_{0} e^{\omega t-k z}, U_{0}^{(0)}=\bar{U}_{0} e^{\omega t-k z},
$$

где $\omega$-круговая частота колебаний; $k$ - волновое число. Подставляя (5.1) в уравнения колебания будем иметь систему двух однородных алгебраических уравнений относительно $\bar{W}_{0}$ и $\bar{U}_{0}$

$$
a_{11} \bar{W}_{0}+a_{12} \bar{U}_{0}=0, a_{21} \bar{W}_{0}+a_{22} \bar{U}_{0}=0,
$$

где

$$
\begin{gathered}
a_{11}=\frac{b_{0}^{2} h_{0}^{3}}{b_{1}^{2} l^{3}} \omega^{4}-\frac{b_{0}^{2} h_{0}^{3}}{b_{1}^{2} l^{3}} \omega^{2} k^{2}, \\
a_{22}=\frac{1}{\xi}\left[\frac{b_{0}^{2} h_{0}^{2}}{2 b_{2}^{2} l^{2}} \omega^{4}-\frac{b_{0}^{2} h_{0}^{2}}{2 b_{2}^{2} l^{2}}\left(1+2 q_{0}\right) \omega^{2} k^{2}-\frac{4 h_{0}^{2}}{3 l^{2}} q_{2}\left(1+h_{2}\right)^{2} k^{4}+\frac{b_{0}^{2}}{b_{2}^{2}} \omega^{2}\right], \\
a_{12}=-\frac{k}{\xi}\left[\frac{b_{0}^{2} h_{0}^{3}}{6 b_{1}^{2} l^{3}}\left(\frac{b_{0}^{2}}{a_{0}^{2}}-2\right) \omega^{4}-\frac{b_{0}^{2} h_{0}^{3}}{6 b_{1}^{2} l^{3}}\left(1+2 q_{0}\right) \omega^{2} k^{2}-\frac{4 h_{0}^{3}}{3 l^{3}} q_{1}\left(1+h_{1}\right)^{2} k^{4}-\frac{b_{0}^{2} h_{0}}{b_{1}^{2} l} \omega^{2}\right], \\
a_{21}=-k\left[\frac{4 h_{0}^{4}}{3 l^{4}} q_{2}\left(1+h_{2}\right)^{2} k^{4}+\frac{b_{0}^{2} h_{0}^{2}}{b_{2}^{2} l^{2}} \omega^{2}+\frac{b_{0}^{2} h_{0}^{4}}{2 b_{2}^{2} l^{4}}\left(1-2 q_{0}\right) \omega^{4}-\frac{b_{0}^{2} h_{0}^{4}}{2 b_{2}^{2} l^{4}}\left(1-2 q_{0}\right) \omega^{2} k^{2}\right] .
\end{gathered}
$$

Из (5.2) следует частотное уравнение

$$
a_{11} \cdot a_{22}-a_{21} \cdot a_{12}=0 \text {. }
$$

Последнее уравнение (5.3) решалось численно с помощью пакета прикладных программ «Maple 17». При этом расчеты проводились для 
стальных и алюминиевых несущих слоев пластины. Значения физикомеханических их параметров материалов следующие: стал - $E=2,0 \cdot 10^{11} \Pi a$; $v=0,25 ; \rho=7850 \mathrm{~kg} / \mathrm{m}^{3} ; \nu=0,25 ; \rho=7850 \kappa 2 / \mathrm{m}^{3} ;$ алюминий $-E=0,7 \cdot 10^{11} \Pi a$; $v=0,35 ; \rho=2750 \mathrm{~kg} / \mathrm{m}^{3}$.

В качестве заполнителя приняты следующие материалы и значения физико-механических их параметров: полимер $\quad E=5,5 \cdot 10^{10} \Pi a ; \quad v=0,4$; $\rho=1700 \mathrm{~kg} / \mathrm{m}^{3}, \quad$ стеклопластик $\quad E=1,8 \cdot 10^{10} \Pi a ; \quad v=0,35 ; \rho=1400 \mathrm{~kg} / \mathrm{m}^{3}$, древесный пластик $E=1,2 \cdot 10^{10} \Pi a ; \quad v=0,35 ; \rho=1200 \mathrm{~kg} / \mathrm{m}^{3}, \quad$ и текстолит $E=0,4 \cdot 10^{10} \Pi a ; v=0,35 ; \rho=1300 \mathrm{~kg} / \mathrm{m}^{3}$.

Геометрические характеристики трехслойной пластины, следующие: толщины внешних слоев $h_{1}=h_{2}=0,001 m$; толщина заполнителя $h_{0}=0,03 ; 0,05 ; 0,1 m$.

\section{6. Результаты расчетов}

Результаты проведенных расчетов приведены на рис. 2-5 в виде зависимостей наименьшей частоты $\omega$ от волнового числа $k$. На рис. 2 представлены кривые зависимости $\omega \sim \mathrm{k}$ трехслойной пластинки при одинаковых толщинах стальных несущих слоев ( рассматривается пластинка симметричной структуры), равных $h_{1}=h_{2}=0,001 m$. При этом рассмотрены три значения толщины заполнителя из полимера, для которых $h_{0}=0,03 ; 0,05 ; 0,1 m$. Легко увидеть, что для всех случаев значения толщины зависимость $\omega \sim \mathrm{k}$ прямо пропорциональная. Из графиков следуют, что при фиксированном значении волнового числа, увеличение толщины срединного слоя пластинки приводит к росту частоты колебаний. Например, значения частоты, 
соответствующие значениям $h_{0}=0,03 ; 0,05 ; 0,1 m$ при отличаются от значения при $h_{0}=0,03$ на $61 \%$ и $178 \%$, соответственно. С увеличением волнового числа, т.е. с переходом на более высокочастотную область, эти разницы увеличиваются все больше.

Сравнение рис. 2 и рис. 3 показывает, что при одинаковых условиях частота колебаний пластинки со стальными несущими слоями всегда меньше чем у пластинки с алюминиевыми несущими слоями. Но, разница небольшая. Например, при $\mathrm{k}=10$ указанная разность составляет $\mathrm{k}=0,05$, что в процентном отношении равно 4\%. Вместе с тем, частота колебаний пластинки сильно зависит от материала заполнителя, которая видна из сравнения графиков на рис. 3 и рис. 4. У пластинки с заполнителем с большим значением модуля упругости (полимер рис.3) частота колебаний меньше, чем с заполнителем с меньшим значением модуля упругости (стеклопластик рис. 4). Например, при $\mathrm{k}=7$ разница составляет: для $h_{0}=0,1-0,98(\approx 120 \%) ; h_{0}=0,1-0,98(\approx 120 \%)$; для $h_{0}=0,05-0,2(\approx 42 \%)$; для $h_{0}=0,03-0,15(\approx 52 \%)$.

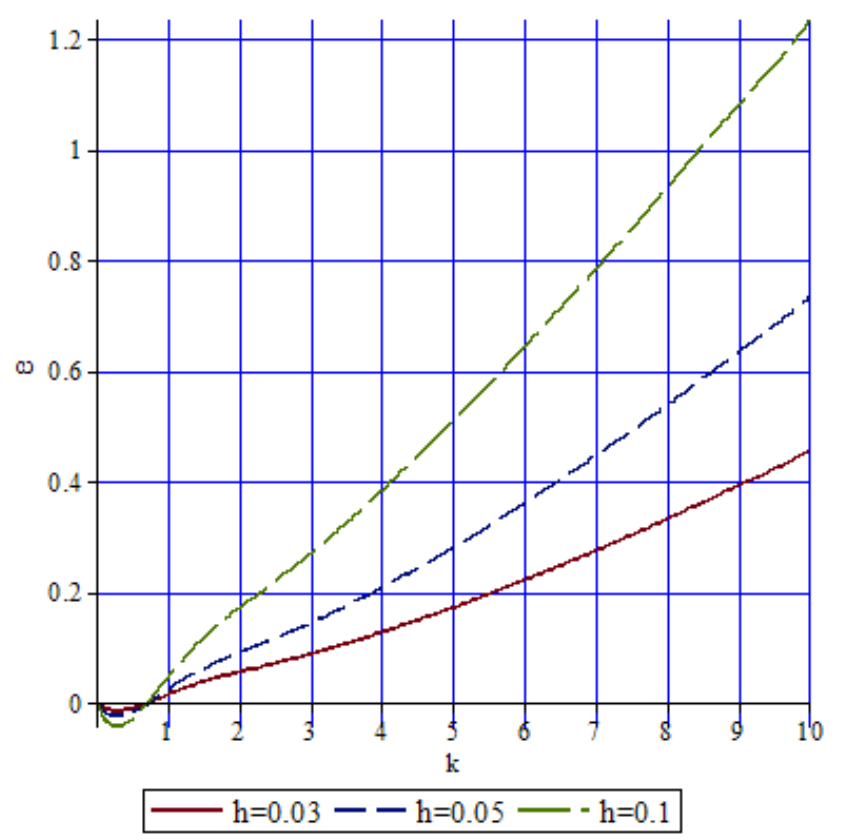

Рис. 2. Зависимости $\omega$ от $k$ при $h_{1}=h_{2}=0,001$ и различных $h_{0}$. Материалы несущих слоев - сталь, а заполнителя - полимер 


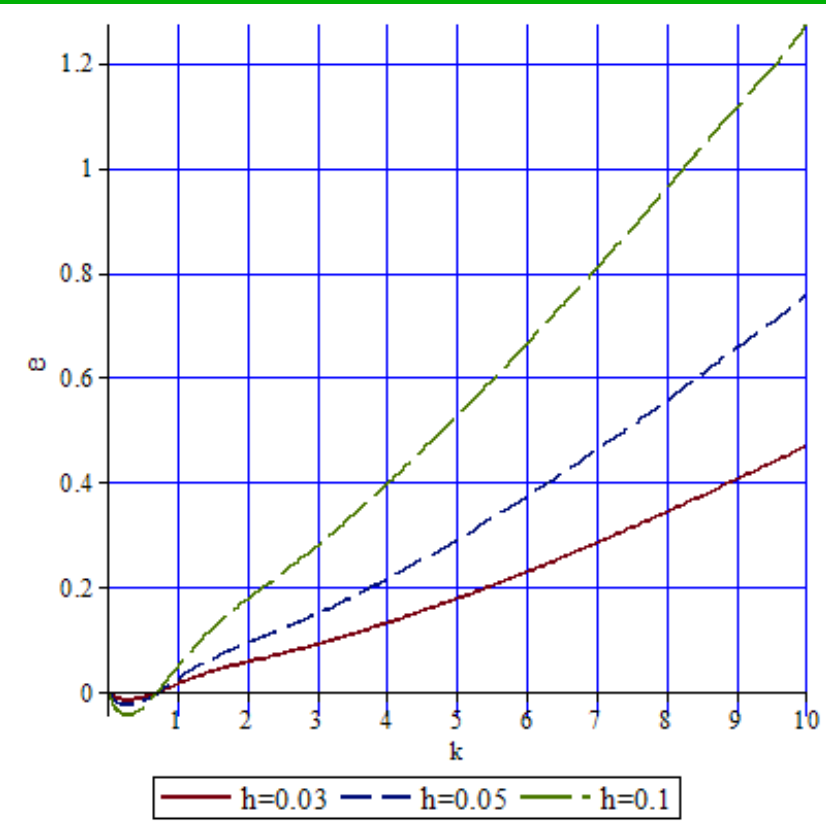

Рис. 3. Зависимости $\omega$ от $k$ при $h_{1}=h_{2}=0,001$ и различных $h_{0}$. Материалы несущих слоев - алюминий, а заполн $h_{0}=0,03 ; 0,05 ; 0,1 m$. ителя - полимер

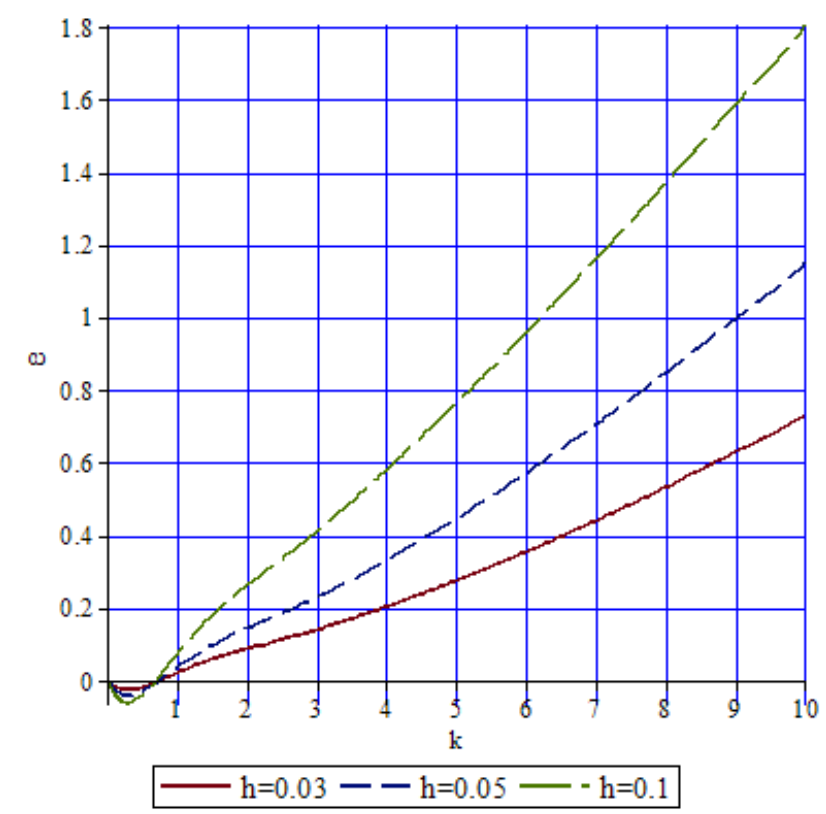

Рис. 4. Зависимости $\omega$ от $k$ при $h_{1}=h_{2}=0,001$ и различных $h_{0}$ • Материалы несущих слоев - алюминий, а заполнителя - стеклопластик 


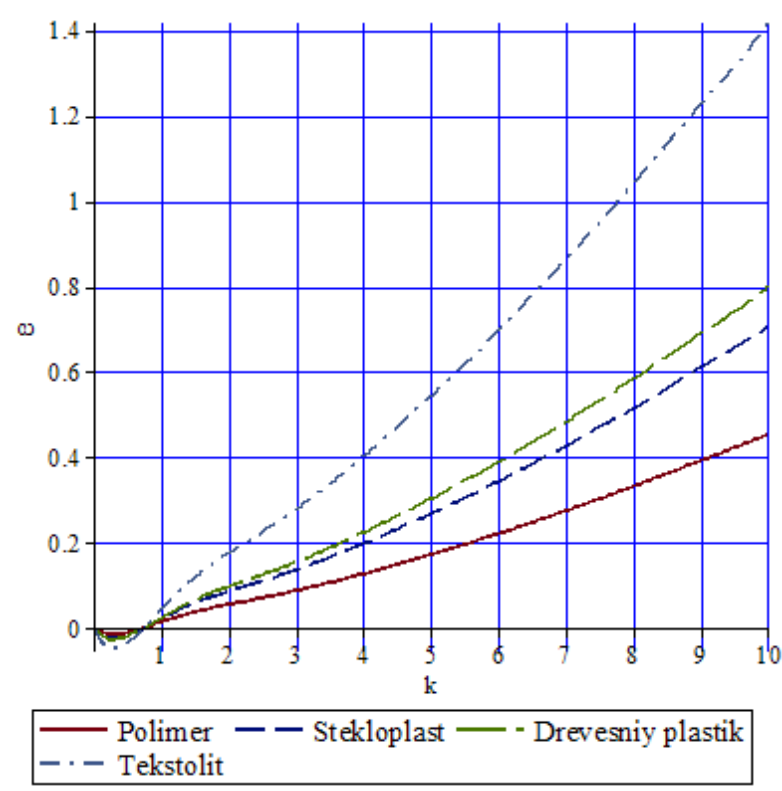

Рис. 5. Зависимости $\omega$ от $k$ при $h_{1}=h_{2}=0,001 ; h_{0}=0,03$. Материалы несущих слоев - сталь, а заполнителя - разные (полимер, стеклопластик, древесный пластик, текстолит)

На рис. 5 приведены графики зависимости $\omega \sim \mathrm{k}$ при значениях толщины стальных несущих слоев равных $h_{1}=h_{2}=0,001$ при $h_{0}=0,03$. В качестве заполнителя приняты полимер, стеклопластик, древесный пластик и текстолит, значения физико-механических параметров которых, приведены выше. Приведенные результаты на рис.5 подтверждают ранее сделанный вывод о том, что у пластинки с заполнителем с большими значениями модуля упругости и плотности частота колебаний меньше чем с заполнителем с меньшими значениями модуля упругости и плотности. Самые меньшие значения модуля упругости и плотности, из приведенного ряда материалов заполнителей у текстолита, которому соответствует большие значения частоты (рис. 5). Например, при $\mathrm{k}=7$ значение частоты для текстолита 0,86, а для полимера 0,26. При этом частоты пластинки со стеклопластиком ниже $(0,44)$ по сравнению с древесным пластиком $(0,48)$, 
несмотря на то, что модуль упругости у стеклопластика больше, чем у древесного пластика. Это объясняется тем, что древесный пластик намного плотнее стеклопластика.

\section{Выводы:}

- разработана теория нестационарных поперечных колебаний упругой трехслойной пластинки на основе общих решений в преобразованиях уравнений теории упругости, в плоской постановке;

- разработанная теория позволяет вычислить все компоненты вектора перемещений и тензора напряжений в сечениях пластинки в целом и всех слоев через введенные главные части промежуточной поверхности срединного слоя;

- полученные общие уравнения колебания позволяют получить уточненные уравнения типа Тимошенко и приближенные уравнения типа Кирхгоффа, которые могут быть применены для решения прикладных задач инженерной практики;

- из сравнительного анализа полученных численных результатов следует, что разработанные в работе уравнения колебания и формулы для определения НДС позволяют высокой степенью достоверности определять частоты антисимметричных колебаний трехслойных пластин. При этом частотный анализ, выполненный на основе представленной модели, требует минимальных вычислительных ресурсов;

- независимо от значения толщины срединного слоя зависимость частоты от волнового числа прямо пропорциональная. При фиксированном значении волнового числа, увеличение толщины срединного слоя пластинки приводит к росту частоты колебаний, которая сильно зависит от материала заполнителя. У пластинки с заполнителем с большими значениями модуля упругости и плотности частота колебаний меньше, чем с заполнителем с меньшими значениями модуля упругости и плотности. 


\section{Список литературы}

1. Егорычев О.А., Егорычев О.О. Нестационарные колебания слоистых упругих и вязкоупругих пластин и пологих сферических и цилиндрических оболочек. - М.: ОЗОП.ГИ., 2012 - 240 с.

2. Sayyad S., Ghugal Y.M. On the free vibration analysis of laminated composite and sandwich plates: A review of recent literature with some numerical results. Composite Structures 129 (2015) 177-201

3. Carrera E. Historical review of zig - zag theories for multilayered plates and shells. // J.Appl Mech Review, vol. 56, №3, 2003. - 287-308 pp.

4. Ren, J. G., A New Theory of Laminated Plate. Composite Science and Technology, 26,3, 1986, pp. 225-239. https://doi.org/10.1016/0266-3538(86)90087-4

5. Carrera E., Brischetto S. A Survey with Numerical Assesment of Classical and Refined Theories for the Analysis of Sandwich Plates // Z. Appl. Mech. Rew. V.62, 2009. -010803-1-17 pp.

6. Lee, K. H., Kin, W. Z., and Chow, S. T., "Bi-Directional Bending of Laminated Composite Plates Using an Improved Zig-Zag Model," Composite Structures, 28, 283-294 (1994). https://doi.org/10.1016/0263-8223(94)90015-9

7. Амбарцумян С.А. Теория анизотропных пластин. - М.: Наука, 1987. $493 \mathrm{c}$.

8. Mantari J.L.,Oktem A.S., Soares C.G. A new higher order shear deformation theory for sandwich and composite laminated plates. Composits: Part B 2012;43: 1489-99. https://doi.org/10.1016/j.compositesb.2011.07.017

9. Karama M, Afaq K.S., Mistou S. A new theory for laminated composite plates. Proc IMechE Part L: J Mater: Des Appl 2009;223: 53-62. https://doi.org/10.1243/14644207JMDA189

10. Daouadji T. H., Hadj Henni A., Tounsi A., \& El Abbes A. B. (2012). A New Hyperbolic Shear Deformation Theory for Bending Analysis of Functionally 
Graded Plates. Modelling and Simulation in Engineering, 2012, 110. doi:10.1155/2012/159806.

11. Thai Ch.H., Tran L.V., Tran D.T., Nguyen-Thoi T., Nguyen-Xuan H. Analysis of laminated composite plates using higher-order shear deformation plate theory and node-based smoothed discrete shear gap method. Appl Math Model 2012; 36: 5657-77. https://doi.org/10.1016/j.apm.2012.01.003

12. Grover N., Singh B.N., Maiti D.K. Analytical and finite element modeling of laminated composite and sandwich plates: An assessment of a new shear deformation theory for free vibration response. Int J Mech Sci 2013;67: 89-99. https://doi.org/10.1016/j.ijmecsci.2012.12.010

13. Bessaim A., Houari M.S.A, Tounsi A. A new higher-order shear and normal deformation theory for the static and free vibration analysis of sandwich plates with functionally graded isotropic face sheets. J Sandw Struct Mater 2013;15(6): 671-703. https://doi.org/10.1177/1099636213498888

14. Xiang S., Jin Ya., Bi Z., Jiang Sh.,Yang M. A n-order shear deformation theory for free vibration of functionally graded and composite sandwich plates. https://doi.org/10.1016/j.compstruct.2011.05.022.

15. Nosier A., Kapania R.K., Reddy J.N., Free Vibration Analysis of Laminated Plates Using a Layerwise Theory. AIAA Journal, 31(12),2335--2346 (1993). https://doi.org/10.2514/3.11933

16. Димитриенко Ю.И., Яковлев Д.О. Сравнительный анализ решений асимптотической теории многослойных тонких пластин и трехмерной теории упругости // Инж. журнал: наука и иннов., 2013, вып.12. - С.1-10. http://engjournal/ru/catalog/mathmodel/technic/899/html.

17. Старовойтов Э.И., Леоненко Д.В. Колебания круговых трехслойных пластин на упругом основании под действием параболических нагрузок //Электронный журнал «Труды МАИ». Выпуск №78. 2013.-С.1-12. http://www.mai.ru/science/trudy/ID=46621. 
18. Петрашень Г.И. Проблемы инженерной теории колебаний вырожденных систем//Исс-я упругости и пластичности. - Л.: Изд-во ЛГУ, 1966 - №5. - C. 3-33.

19. Филиппов И.Г., Чебан В.Г. Математическая теория упругих и вязкоупругих пластин и стержней. - Кишинев: Штиинца, 1988. -190 с.

20. Ismayilov K., Karimova K. Application of used automobile tires granules for road construction in Uzbekistan. Journal of Critical Reviews, 2020. V.7, No12, pp 946-948. DOI: 10.31838/jcr.07.12.165.

21. Kubaymurodov D.I., Ismayilov K., Ibragimov A. Application of the Bubnov-Galerkin method to determine the statistical characteristics of the state of a prismatic shell. Prospective research solutions collection of articles of the IIIInternational Scientific and Technical Competition. p. 1131212021 Petrozavodsk https://www.elibrary.ru/item.asp?id=44587093. DOI: 10.46916 / 22012021-3-978-500174-117-6.

22. Ismayilov K. Critical strains and critical stresses in the steel rod beyond the elastic limit. European Science Review. 2018, № № 5-6.

23. Ismayilov K., Karimova K. The Impact of Automobile Tires on the Environment from the Period of Raw Materials to Their Disposal, Retrieval Volume8 Issue-3, September 2019. Number: C4473098319/19 C BEIESP DOI:10.35940/ijrte.C4473.098319.

24. Ismayilov K., Suleymanov A., Toshev S., Ruziev S. Option of the Method of Successive Approximations in Calculating the Epicenters of Extreme and Emergency Situations. Ilkogretim Online - Elementary Education Online, 2021; 20 (3): pp. 1640-1647 http://ilkogretim-online.org doi: 10.17051/ilkonline.2021.03.186.

25. Mavlonov T., Yuldoshev B., Ismayilov K., Toshev S. Compressed rectangular plates stability beyond the elastic limit. IOP Conference Series: Materials Science and Engineering. 2020. DOI:10.1088/1757-899X/883/1/012199. 
26. Ismayilov K. Stability of compressed rods, plates and shells beyond the elastic limit. FAN. Samarkand, 2003, p. 280.

27. Ismayilov K., Suleymanov S.T., Ruziev S.T., Aripjanova M.B. A new method of successive approximations when calculating elements of electromechanical machines.XXI Century. Technosphere Safety. 2020; 5(2):168-172. (In Russ.) https://doi.org/10.21285/2500-1582-2020-2-168-172.

28. Ismayilov K. On the stability of a compressed bar beyond elasticity nternational Congress. Spatial structures in new construction during the reconstruction of buildings and structures. MKPK98. Moscow 1998.p.46.

29. Ismayilov K. Stress strain state of a circular plate beyond the elastic limit. Innovative discourse of the development of modern science and technology. Collection of articles of the International Scientific and Practical Conference, held in Petrozavodsk on May 10, 2021. pp. 7-23. DOI 10.46916 / 12052021-1-978-5-00174228-9

30. Kubaymuradov D.I, Mamasoliev K. Calculation of two-layer beam plates lying on a non-uniform foundation. Modern achievements of youth science: a collection of articles of the International Research Competition (May 11, 2021). Petrozavodsk: ICNP "New Science", 2021. - p. 55-66

31. Ismayilov K. Development of society and science in the digital economy. "Stability of compressed rods, plates and shells beyond the elastic limit" Petrozavodsk ICNP "New Science" Monograph. 2021 200s. ISBN 978-5-00174-2937. DOI 10.46916/ 19082021-1-978-5-00174-293-7.

32. Ismayilov K. Stress-strain state of a circular plate beyond the elastic limit. Innovative discourse of the development of modern science and technology. Collection of articles of the International Scientific and Practical Conference, held in Petrozavodsk on May 10, 2021. pp. 7-23. DOI 10.46916 / 12052021-1-978-5-00174228-9. 


\title{
УДК 624.04
}

\section{Глава 10.}

ЗАМКУТЫЕ ПРИЗМАТИЧЕСКИЕ ОБОЛОЧКИ НА НЕОДНОРОДНОМ УПРУГОМ ОСНОВАНИИ

\author{
Ибрагимов Абдижаббар \\ кандидат технических наук, доцент \\ Самаркандский государственный \\ архитектурно-строительный институт
}

Аннотация: в данной главе монографии рассмотрены призматические оболочки, расположенные на неоднородном упругом основании с различными условиями закрепления торцевых сечений (опирание на жесткие диафрагмы, свободное положение торцов). Также при помощи вариационного метода В.3. Власова проведено исследование напряженно-деформированного состояния оболочки при различных регулярных законах изменения коэффициента постели вдоль ее оси. Рассмотрены задачи изгиба и кручения оболочки под действием симметричной и кососимметричной нагрузок относительно вертикальной плоскости, проходящей через продольную ось.

Полученные результаты могут быть использованы в дальнейшем при проектировании трубопроводов и замкнутых призматических конструкций в различных областях техники.

Ключевые слова: оболочка, основания, перемещения, нормальные и касательные напряжения, контур, дифференциал, неоднородность, граничные условия. 


\title{
CLOSED PRISMATIC SHELLS ON AN INHOMOGENEOUS ELASTIC BASE
}

\section{Ibragimov Abdizhabbar}

\begin{abstract}
: in this chapter of the monograph, prismatic shells located on an inhomogeneous elastic base with different conditions for fixing the end sections (resting on rigid diaphragms, free position of the ends) are considered. Also, using the variational method of V.Z. Vlasov, a study of the stress-strain state of the shell under various regular laws of variation of the bed coefficient along its axis was carried out. The problems of bending and torsion of the shell under the action of symmetric and skew-symmetric loads relative to the vertical plane passing through the longitudinal axis are considered. The results obtained can be used in the future in the design of pipelines and closed prismatic structures in various fields of technology.
\end{abstract}

Keywords: shell, bases, displacements, normal and tangential stresses, contour, differential, inhomogeneity, boundary conditions.

\section{Введение}

Все инженерные сооружения в той или иной степени взаимодействуют с подстилающим их основанием, и эффект такого взаимодействия может быть столь значительным, что с ним нельзя не считаться в практике проектирования. В связи с этим, проблема совершенствования методов расчета сооружений, работающих совместно с грунтовым основанием, имеет важное народнохозяйственное значение.

Теория расчета балок, плит и оболочек на упругом основании представляет собой обширный раздел современной строительной механики и 
теории упругости. Многочисленные исследования в этой области показывают, что максимального экономического эффекта можно достигнуть, применяя такие методы расчета сооружений, взаимодействующих с грунтом, которые наиболее полно отражают действительные условия работы оснований. Известно, что физико-механические характеристики грунтового массива в природном залегании даже в пределах малых площадок изменяются, и эти изменения имеют случайный характер. Поэтому в целях обеспечения надежной работы инженерных сооружений, целесообразной является статистическая модель упругого основания, предложенная В.В. Болотиным и Д.Н. Соболевым. Такая модель позволяет определить напряженное состояние сооружений, находящихся в сложных условиях эксплуатации.

Статистическая неоднородность упругого основания вызывает в конструкциях разброс усилий и деформаций относительно средних значений, полученных для детерминистического основания. Определение вероятностных характеристик этого разброса и является задачей статистического расчета. Конечная цель расчета заключается в оценке вероятности безотказной работы конструкции в течение срока эксплуатации и создание оптимального варианта с учетом его надежности. Такой подход позволяет обеспечить снижение материалоемкости конструкций, повысить их эффективность в реальных условиях эксплуатации. Тем не менее каждое исследование, отражающее более полно действительный характер работы сооружения, взаимодействующего с грунтом, позволяет получить весомую экономию материальных затрат, учитывая грандиозные масштабы строительства, осуществляемого в нашей стране.

Тонкостенные пространственные конструкции, состоящие из пластинок и оболочек, находят все более широкое применение в различных отраслях современной техники. Широкое применение этих конструкций обусловлено не только их техническими особенностями, но также и значительными 
экономическими преимуществами перед обычными. Однако изучение взаимодействия таких конструкций со случайно-неоднородным основанием практически не проводилось.

\section{1. Дифференциальные уравнения равновесия многосвязной призматической оболочки, расположенной на упругом основании}

Рассмотрим призматическую оболочку длины $\ell$ и ширины $b$, состоящую из горизонтальных и вертикальных пластин, толщина которых равна соответственно $\delta_{1}$ и $\delta_{2}$. Оболочка могут быть расположена на поверхности упругого основания (рис.1) или в упругой среде (рис.2). В качестве упругого основания примем Винклеровскую модель, согласно которой коэффициент постели $c(z)$ в общем случае считается функцией продольной координаты $z$. Внешняя нагрузка предполагается приложенной в узлах сопряжения горизонтальных и вертикальных пластика.

Для решения задачи воспользуемся вариационным методом В.3.Власова, в соответствии с которым искомые продольные $u(z, s)$ и тангенциальные $v(z, s)$ перемещения представляются в виде следующих разложений:

$$
u(z, s)=\sum_{i=1}^{m} u_{i}(z) \varphi_{i}(s), v(z, s)=\sum_{k=1}^{n} v_{k}(z) \psi_{k}(s)
$$

Здесь $u_{i}(z), v_{k}(z)$ - искомые обобщенные перемещения, а $\varphi_{i}(s), \psi_{k}(s)$.(s) - функции поперечного распределения перемещения.

Условия равновесия элементарной рамы шириной $d z$, выделенной двумя поперечными сечениями из оболочки, позволяют записать две системы обыкновенных дифференциальных уравнений следущего вида: 


$$
\begin{aligned}
& \sum_{i=1}^{m}\left(\gamma a_{j i} u_{i}^{\prime \prime}-b_{j i} u_{i}\right)-\sum_{k=1}^{n} c_{j k} v_{i k}^{\prime}+\frac{p_{j}}{G}=0 ;(j=1,2,3, \ldots, m) \\
& \sum_{i=1}^{m} \bar{c}_{h i} u_{i}^{\prime}+\sum_{k=1}^{n}\left[r_{h k} v_{k}^{\prime \prime}-\left(\gamma S_{h k}+K_{h k}\right) v_{R}\right]+\frac{q_{h}}{G}=0 ;(h=1,2,3, \ldots .,) .
\end{aligned}
$$

Здесь:

$$
\begin{gathered}
\gamma=\frac{E}{G} ; \quad p_{i}=\int p \varphi_{j} d s ; \quad q_{h}=\int q \psi_{h} d s ; \quad a_{j i}=\int \varphi_{j} \varphi_{i} d F ; \quad b_{j i}=\int \varphi_{j}^{\prime} \varphi_{i}^{\prime} d F ; \\
c_{j k}=\int \varphi_{j}^{\prime} \psi_{k} d F ; \quad c_{h i}=\int \psi_{h} \varphi_{i}^{\prime} d F ; r_{h k}=\int \psi_{h} \psi_{k} d F ; \quad d F=\delta d s ; \\
S_{h k}=\frac{1}{E} \int \frac{M_{h} M_{k}}{E I} d s ; \quad K_{h k}=\frac{1}{G} \int c(z) \psi_{h}^{\prime} d s .
\end{gathered}
$$

Коэффициентами $K_{h k}(z)$ учитывается работа упругого основания на возможных перемещениях $\bar{\psi}_{h}(s)$, которые характеризуют нормальные по отношению к контуру поперечного сечения оболочки перемещения (для выбранной функции $\psi_{h}(s)$ ). Эти коэффициенты являются функциями координаты $z$, в результате чего вторая система уравнений (2) имеет переменные коэффициенты при искомых функциях $v_{k}$.

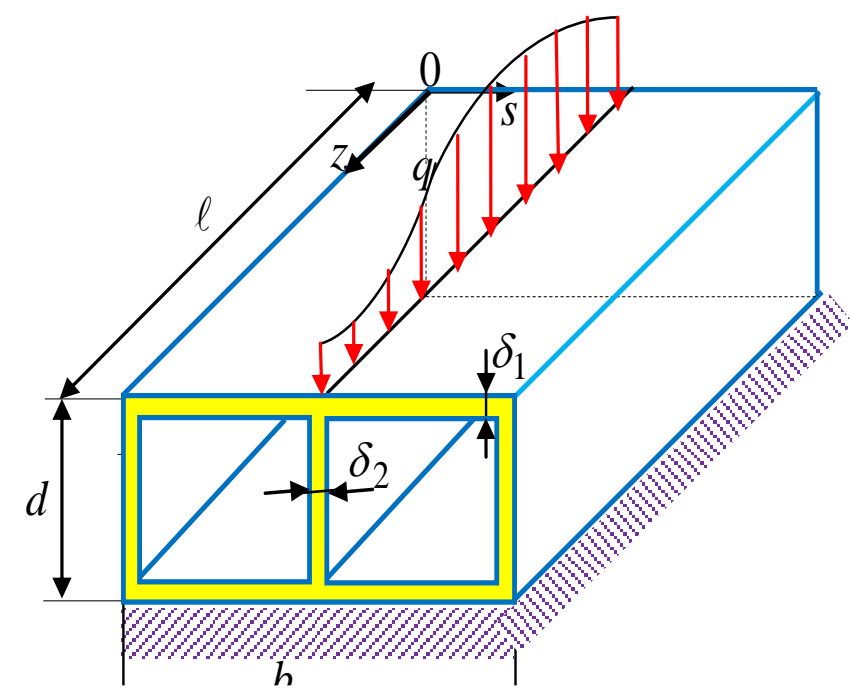

Рис. 1. Упругое основание 

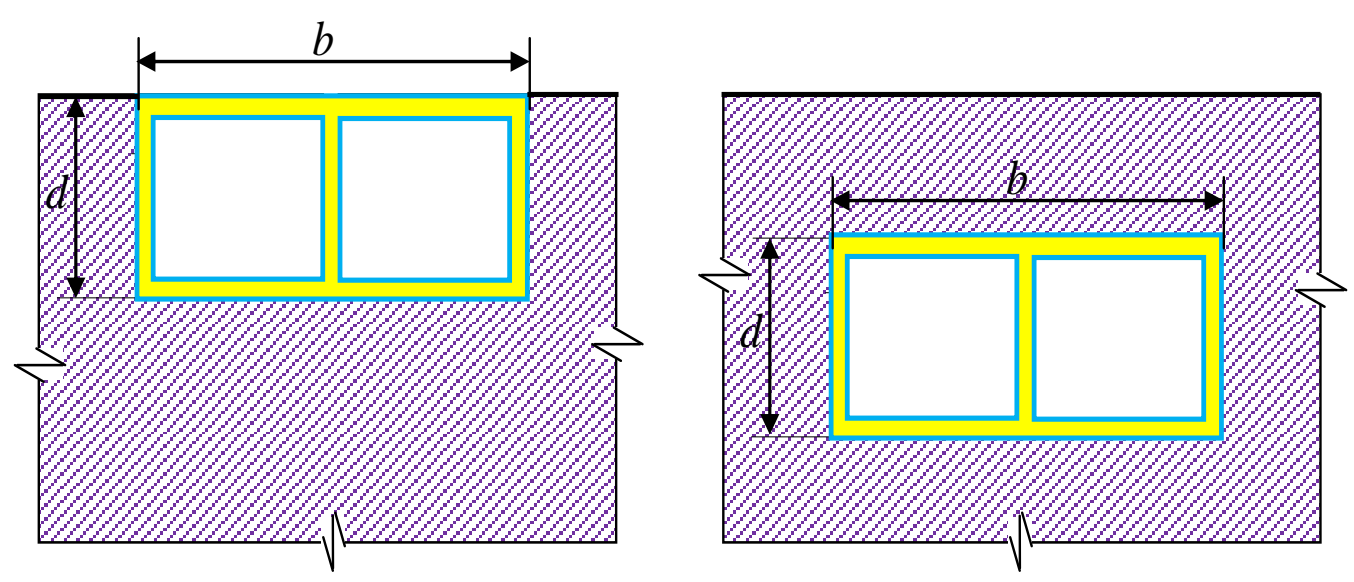

Рис. 2. Упругая среда

На рис.3 и 4 приведен возможный вариант выбора функций поперечного распределения перемещений $\varphi_{i}(s), \psi_{k}(s)$ для двухсвязного симметричного контура поперечного сечения оболочки. Можно видеть, что функциями $\varphi_{1}, \varphi_{2}, \varphi_{3}$ описывается гипотеза плоских сечений соответственно при растяжении оболочки и ее изгибе относительно горизонтальной и вертикальной осей. Функции $\varphi_{4}, \varphi_{5}, \varphi_{6}$ характеризует депланацию поперечного сечения. Их ординаты $a, b, c$ подбираются из условий ортогональности:

$$
\int \varphi_{1} \varphi_{4} d F=0 ; \int \varphi_{2} \varphi_{5} d F=0
$$

что в дальнейшем упрощает систему уравнений (2). Функции $\psi_{1}, \psi_{2}$ и $\psi_{3}$ определяют смещения поперечного сечения как жесткого диска: соответственно вертикальное и горизонтальное смещение и поворот относительно геометрического центра сечения. Функциями $\psi_{4}$ и $\psi_{5}$ характеризуются деформации поперечного сечения. Ординаты $d$ и $e$ подбирается здесь из условия ортогональности:

$$
\int \psi_{3} \psi_{5} d F=0
$$



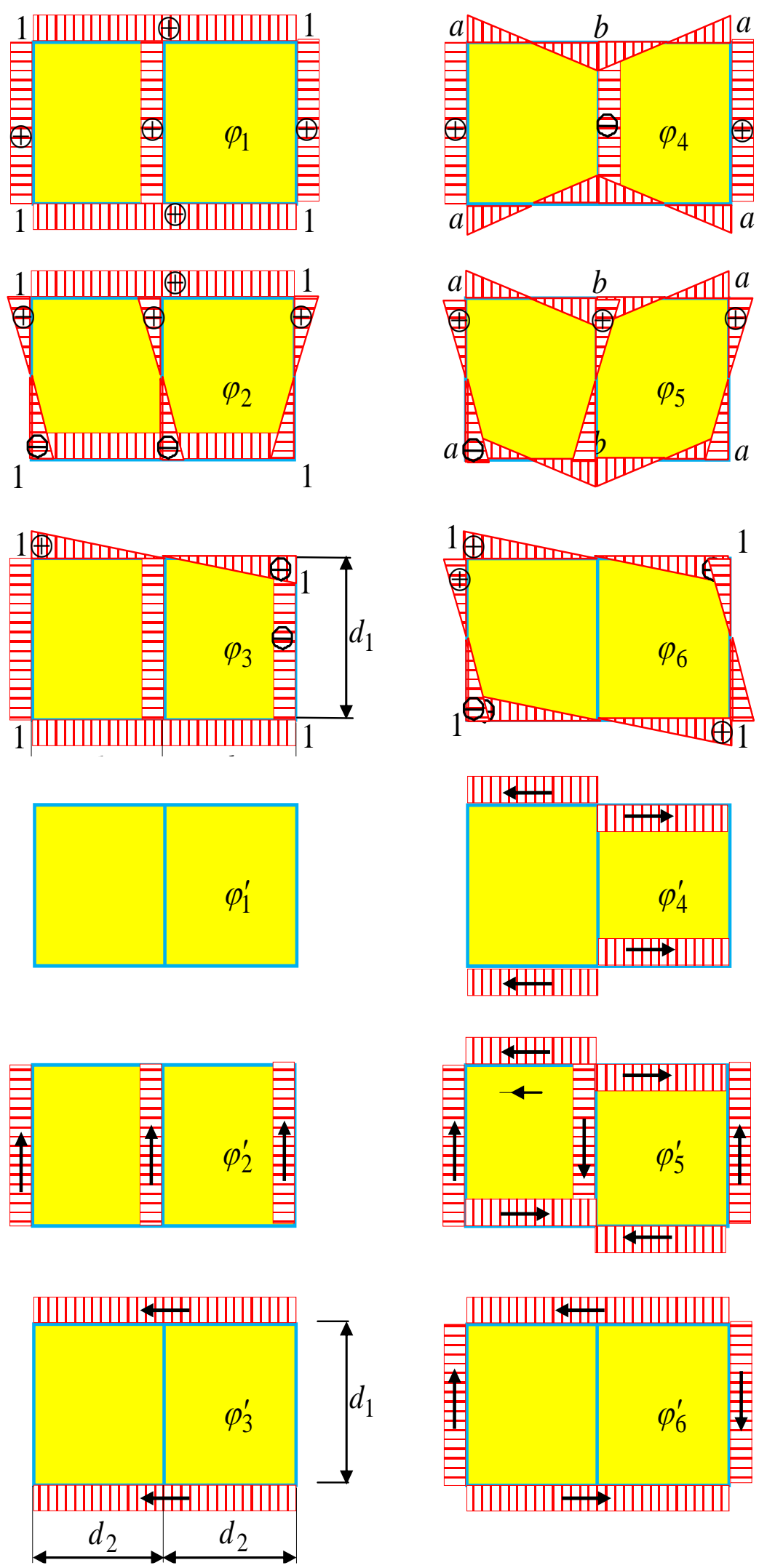

Рис. 3. Возможный вариант функций поперечного распределения перемещений 

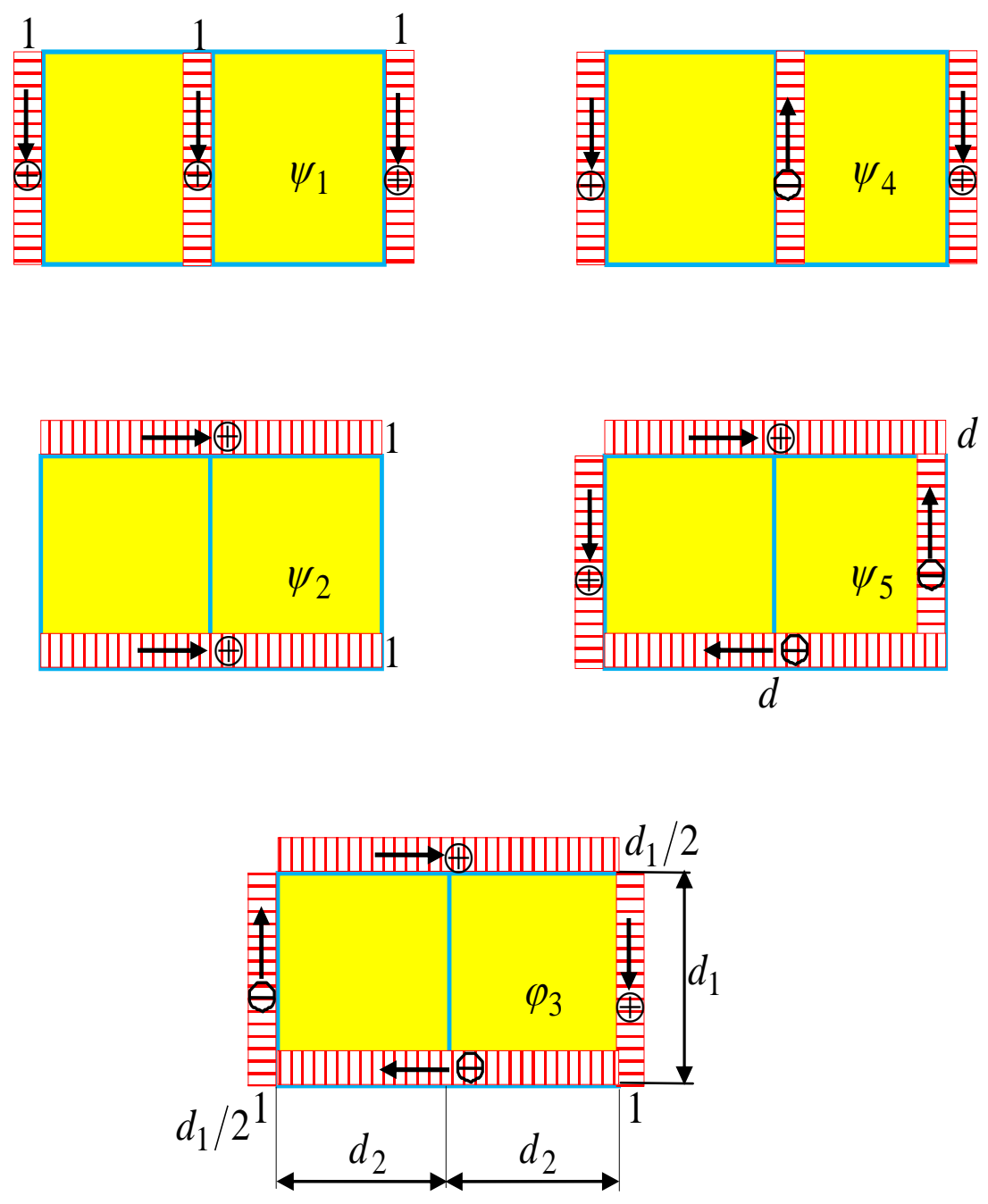

Рис. 4. Возможный вариант функций поперечного распределения перемещений

Вследствие ортогональности выбранных функций $\varphi_{i}, \psi_{k}$ и эпюр $M_{k}$ (рис. 5) многие из коэффициентов (3) обращаются в ноль. При этом система уравнений (2) упрощается и принимает в развернутой форме следующий вид: 

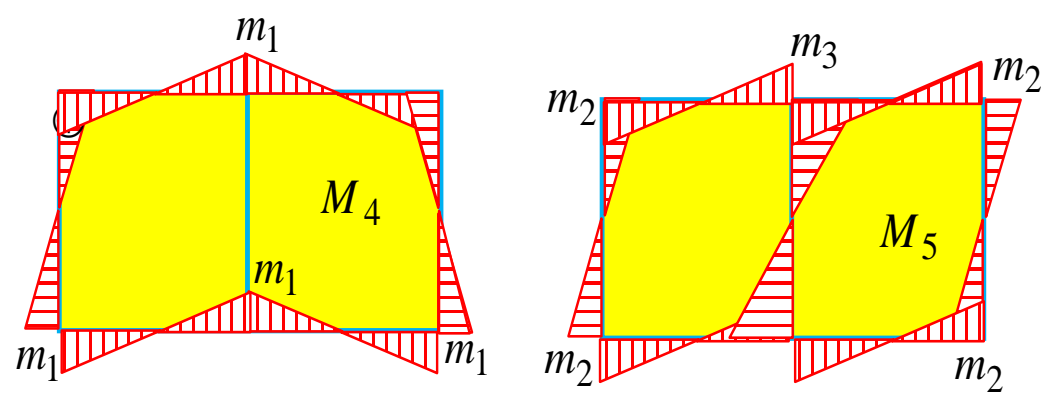

\section{Рис. 5. Эпюры моментов}

$$
\left.\begin{array}{c}
\gamma a_{11} u_{1}^{\prime \prime}+\frac{p_{1}}{G}=0 ; \quad \gamma\left(a_{22} u_{2}^{\prime \prime}-b_{22} u_{2}\right)-c_{21} v_{1}^{\prime}+\frac{p_{2}}{G}=0 ; \\
\gamma\left(a_{33} u_{3}^{\prime \prime}-b_{33} u_{3}\right)-c_{32} v_{2}^{\prime}+\frac{p_{3}}{G}=0 ; \quad \gamma\left(a_{44} u_{4}^{\prime \prime}-b_{44} u_{4}\right)+\frac{p_{4}}{G}=0 ; \\
\gamma\left(a_{55} u_{5}^{\prime \prime}-b_{55} u_{5}\right)-c_{51} v_{1}^{\prime}-c_{54} v_{4}^{\prime}+\frac{p_{5}}{G}=0 ; \\
\gamma\left(a_{66} u_{6}^{\prime \prime}-b_{66} u_{6}\right)-c_{63} v_{3}^{\prime}-c_{65} v_{5}^{\prime}+\frac{p_{6}}{G}=0 . \\
\bar{c}_{12} u_{2}^{\prime}+\bar{c}_{15} u_{5}^{\prime}+r_{11} v_{1}^{\prime \prime}-\sum_{k=1}^{5} K_{1 k} v_{k}+\frac{q_{1}}{G}=0 \\
\bar{c}_{23} u_{3}^{\prime}+r_{22} v_{2}^{\prime \prime}-\sum_{k=1}^{5} K_{2 k} v_{k}+\frac{q_{2}}{G}=0 \\
\bar{c}_{34} u_{4}^{\prime}+r_{33} v_{3}^{\prime \prime}-\sum_{k=1}^{5} K_{3 k} v_{k}+\frac{q_{3}}{G}=0 ; \\
\bar{c}_{45} u_{5}^{\prime}+r_{44} v_{4}^{\prime \prime}-\gamma S_{44} v_{4}-\sum_{k=1}^{5} K_{4 k} v_{k}+\frac{q_{4}}{G}=0 \\
\bar{c}_{56} u_{6}^{\prime}+r_{55} v_{5}^{\prime \prime}-\gamma S_{55} v_{5}-\sum_{k=1}^{5} K_{5 k} v_{k}+\frac{q_{5}}{G}=0
\end{array}\right\}
$$

При решении уравнений (2) граничные условия для сечений $z=0$ и $z=\ell$ оболочки ставятся в обобщенной форме: через обобщенные перемещения $u_{i} ; v_{k}$ и обобщенные усилия: 


$$
p_{j}=E \sum_{i=1}^{6} a_{j i} u_{i}^{\prime} ;(j=1,2, \cdots, 6) ; Q_{h}=G\left(\sum_{i=1}^{6} c_{h i} u_{i}+\sum_{k=1}^{5} r_{h k} v_{k}^{\prime}\right) ;(h=1,2, \cdot, 5) .
$$

После определения искомых функций $u_{i} ; v_{k}$ нормальные $\sigma$ и касательные $\tau$ напряжения в оболочке определяются по известным формулам:

$$
\left.\sigma(z, s)=E \sum_{i=1}^{m} u_{i}^{\prime}(z) \varphi_{i}(s) ; \tau(z, s)=G\left(\sum_{i=1}^{m} u_{i} \varphi_{i}(s)+\sum_{k=1}^{n} v_{k}^{\prime}(z) \psi_{k}(s)\right)\right\}
$$

Для призматической оболочки с односвязным контуром поперечного сечения (рис.6) примем функции поперечного распределения перемещений $\varphi_{i} ; \psi_{k}$ в виде, показанном на рис.7. При этом дифференциальные уравнения (2) запишутся в виде:

$$
\left.\begin{array}{c}
\gamma a_{11} u_{1}^{\prime \prime}+\frac{p_{1}}{G}=0 ; \\
\gamma\left(a_{22} u_{2}^{\prime \prime}-b_{22} u_{2}\right)-c_{22} v_{2}^{\prime}+\frac{p_{2}}{G}=0 ; c_{22} u_{2}^{\prime}+r_{22} v_{2}^{\prime \prime}+\frac{q_{2}}{G}=0 . \\
\gamma a_{33} u_{3}^{\prime \prime}-b_{33} u_{3}-c_{33} v_{3}^{\prime}+\frac{p_{3}}{G}=0 ; \\
c_{33} u_{5}^{\prime \prime}+r_{33} v_{3}^{\prime \prime}+\frac{q_{33}}{G}+\frac{p_{3}}{G}=0 . \\
\gamma a_{44} u_{4}^{\prime \prime}-b_{44} u_{4}-c_{41} v_{1}^{\prime}-c_{44} v_{4}^{\prime}+\frac{p_{4}}{G}=0 ; \\
c_{14} u_{4}^{\prime}+r_{11} v_{1}^{\prime \prime}+r_{14} u_{4}^{\prime \prime}+\frac{\bar{q}_{11}}{G}+\frac{\bar{q}_{14}}{G}+\frac{q_{1}}{G}=0 ; \\
c_{44} u_{4}^{\prime}+r_{41} v_{1}^{\prime \prime}+r_{44} v_{4}^{\prime \prime}-\gamma s_{44} v_{4}+\frac{\bar{q}_{41}}{G}+\frac{\bar{q}_{44}}{G}+\frac{q_{4}}{G}=0 .
\end{array}\right\}
$$

Здесь:

$$
\left.\begin{array}{c}
\bar{q}_{33}=-c(z) v_{3} \bar{\psi}_{3}^{2} ; \quad \bar{q}_{41}=-c(z) v_{1} \bar{\psi}_{1} \bar{\psi}_{4} ; \\
\bar{q}_{11}=-c(z) v_{1} \bar{\psi}_{1}^{2} ; \quad \bar{q}_{44}=-c(z) v_{4} \bar{\psi}_{4}^{2} ; \\
\bar{q}_{14}=-c(z) v_{4} \bar{\psi}_{1} \bar{\psi}_{4} .
\end{array}\right\}
$$




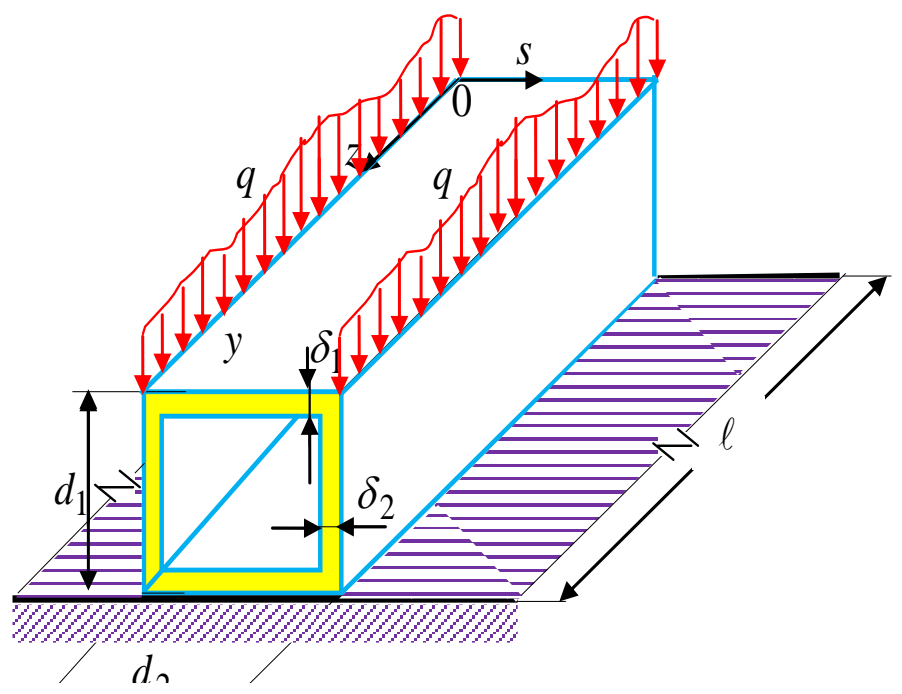

Рис. 6. Призматическая оболочка с односвязным контуром поперечного сечения
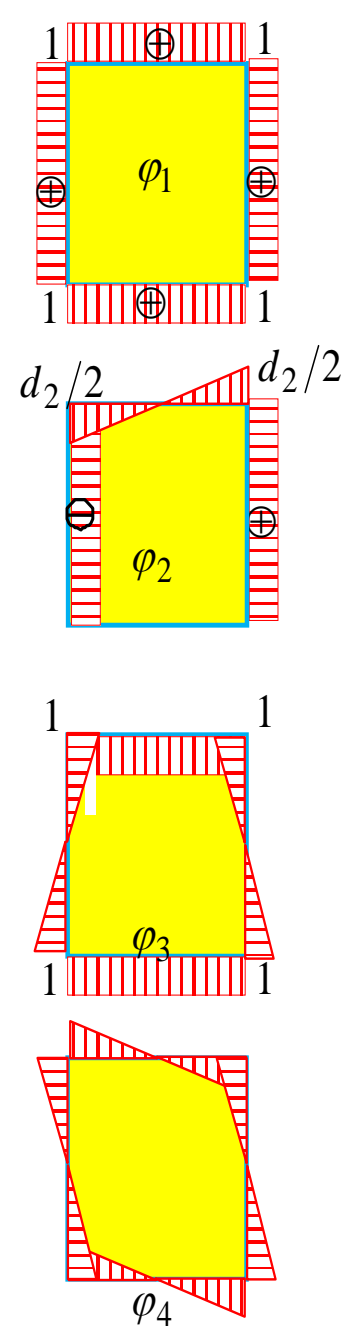
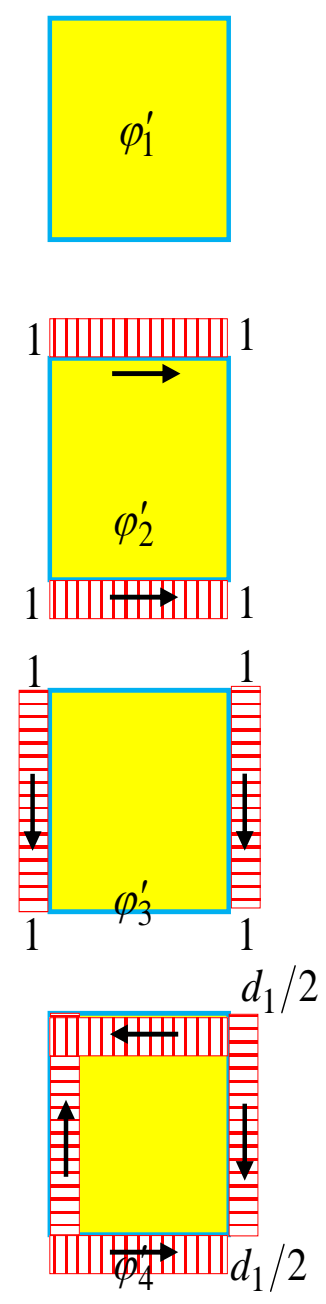
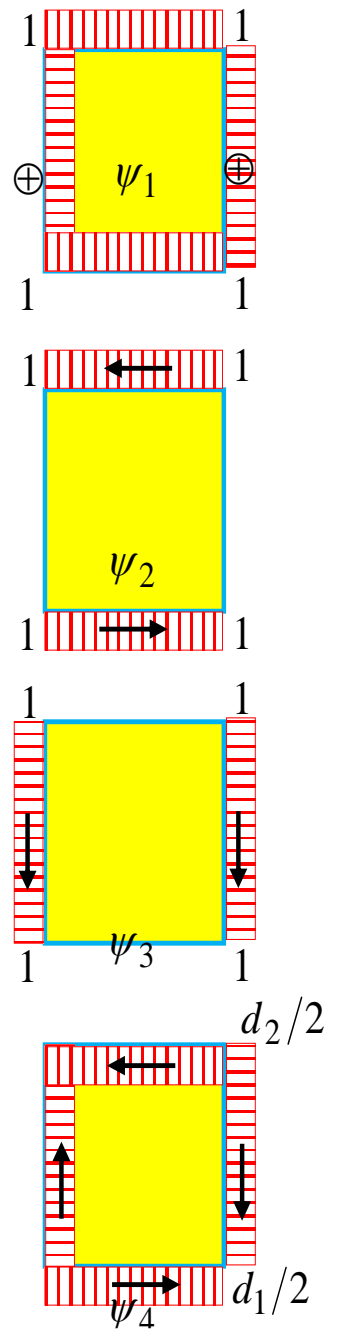

Рис. 7. Функции поперечного распределения перемещений 
Эпюра изгибающих моментов, соответствующая деформации контура поперечного сечения и необходимая для вычисления коэффициента $s_{44}$, показана на рис.8, где:

$$
M=\frac{12}{\left(\frac{d_{1}}{E I_{1}}+\frac{d_{2}}{E I_{2}}\right)} v_{4} ; I_{1}=\frac{\delta_{1}^{3}}{12} ; I_{2}=\frac{\delta_{2}^{3}}{12} .
$$

Уравнением (8) описывается растяжение оболочки вдоль оси $z$, уравнениями (9) и (10) изгиб соответственно в горизонтальной и вертикальной плоскостях, уравнениями (11) - кручение оболочки, сопровождающееся искривлением контура поперечного сечения и его депланацией.

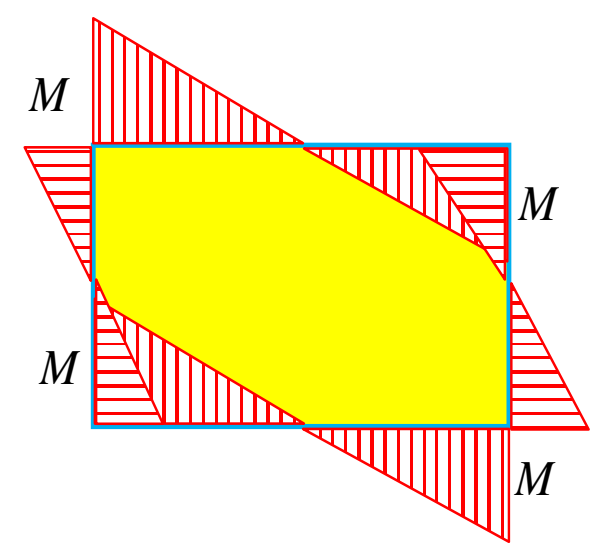

Рис. 8. Эпюра изгибающих моментов

В дальнейшем, как отмечалось выше, рассмотрим загружение оболочки только вертикальной нагрузкой, приложенной по линиям сопряжения горизонтальных и вертикальных пластин (рис.6). В этом случае задача сведется к решению уравнений (10) и (1I), в которых нужно положить равными нулю члены, содержащие $p_{3}$ и $p_{4}$. Уравнениями (10) и (11) будет определяться соответственно изгиб и кручение оболочки.

При разложении заданной вертикальной нагрузки на симметричную и кососимметричную составляющую мы получим задачу об изгибе оболочки при 
действии симметричной части нагрузки и задачу о кручении при действии кососимметричной нагрузки.

Статические граничные условия для искомых функций формулируются вновь при помощи выражений (6). Так для наиболее распространенных типов граничных условий, которые характеризуются свободными от закреплений и нагрузки торцами оболочки или торцами, усиленными жесткими в своей плоскости и гибкими из плоскости диафрагмами, мы подучим:

а) в случае свободных торцов в задаче об изгибе оболочки:

$$
u_{3}^{\prime}=0 ; \quad c_{33} u_{3}+r_{33} v_{3}^{\prime}=0
$$

в задаче о кручении:

$$
\begin{gathered}
u_{4}^{\prime}=0 \\
c_{14} u_{4}+r_{11} v_{1}^{\prime}+r_{14} v_{4}^{\prime}=0 . \\
c_{44} u_{4}+r_{41} v_{1}^{\prime}+r_{44} v_{4}^{\prime}=0 .
\end{gathered}
$$

б) в случае жестких диафрагм в зада че об изгибе оболочки:

$$
u_{3}^{\prime}=v_{3}^{\prime}=0
$$

в задаче о кручении:

$$
u_{4}^{\prime}=v_{1}=v_{3}=0
$$

Из выражений (15) и (16) можно видеть, что в случае жестких диафрагм, помещенных в горцах оболочки, решение уравнения (10) и (11) может быть получено при помощи тригонометрических рядов.

\section{2. Изгиб призматической оболочки, опертой по торцам на жесткие диафрагмы}

Рассмотрим односвязную призматическую оболочку, расположенную на упругом основании винклеровского типа (рис. 9). Будем предполагать, что коэффициент постели упругого основания является известной функцией 
координаты $z$, а оболочка находится под действием нагрузки, симметричной относительно вертикальной плоскости $y 0 x$. Предположим также, что торцы оболочки оперты на жесткие в своей плоскости и гибкие из плоскости диафрагмы.

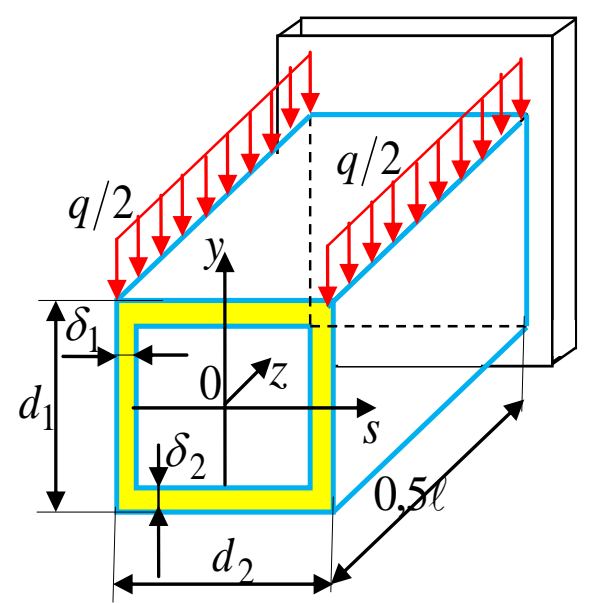

Рис. 9. Односвязная призматическая оболочка, расположенная на упругом основании винклеровского типа

Для решения поставленной задачи применим вариационный метод В.3.Власова, для чего представим искомые перемещения в виде следующих разложений

$$
\left.\begin{array}{ll}
u(z, s)=\sum_{i=1}^{m} u_{i}(z) \varphi_{i}(s) ; & (i=1,2 \cdots, m) \\
v(z, s)=\sum_{k=1}^{n} v_{k}(z) \psi_{k}(s) ; & (k=1,2 \cdots, n)
\end{array}\right\}
$$

где $u(z, s)$ обозначено перемещение точки пластинки в направление образующей, а через $v(z, s)$ перемещение той не точки в направлении касательной к контуру поперечного сечения; $u_{i}(z)$ и $v_{k}(z)$ - искомые функции, зависящие только от $z$ и представляющие собой обобщенные перемещения; $\varphi_{i}(s)$ и $\psi_{k}(s)$ - координатные функции, подлежащие представляющие выбору. 
Учитывая, что симметричная нагрузка будет вызывать только изгиб оболочки без кручения и деформации контура, координатные Функции выберем в виде, представленном на рис. $(10, a)$, то есть ограничимся в суммах (17) лишь первыми членами. При этом дифференциальные уравнения, характеризующие условия равновесия призматической оболочки, запишутся в виде:

$$
a u^{\prime \prime}-b u-b v^{\prime}=0 ; \quad b u^{\prime}+b v^{\prime \prime}-\bar{Q} v=-Q
$$

где

$$
\begin{gathered}
a=\gamma a_{i j}=\frac{E}{G} \int_{s} \varphi_{i} \varphi_{j} \delta d s=\frac{1}{6}\left(d_{1}^{3} \delta_{1}+3 d_{2} d_{1}^{2} \delta_{2}+d_{2} \delta_{2}^{3}\right) \\
b=b_{i j}=\int_{s} \varphi_{i} \varphi_{j} d s=2 d_{1} \delta_{1} \\
\bar{Q}=\frac{1}{G} \int_{s} c(z) \bar{\psi}(s) d s=\frac{1}{6} \int_{s} c \psi(s) d s=\frac{d_{2}}{G} c \\
Q=\frac{1}{G} \int_{s} q(z, s) \psi_{n}(s) d s=\frac{q(z)}{G} .
\end{gathered}
$$

Коэффициентом $\bar{Q}$, входящим в формулы (19), представлены работа реакций упругого основания, равномерно распределенных по плоскости контакта оболочки с основанием (рис.10, $b$ ).

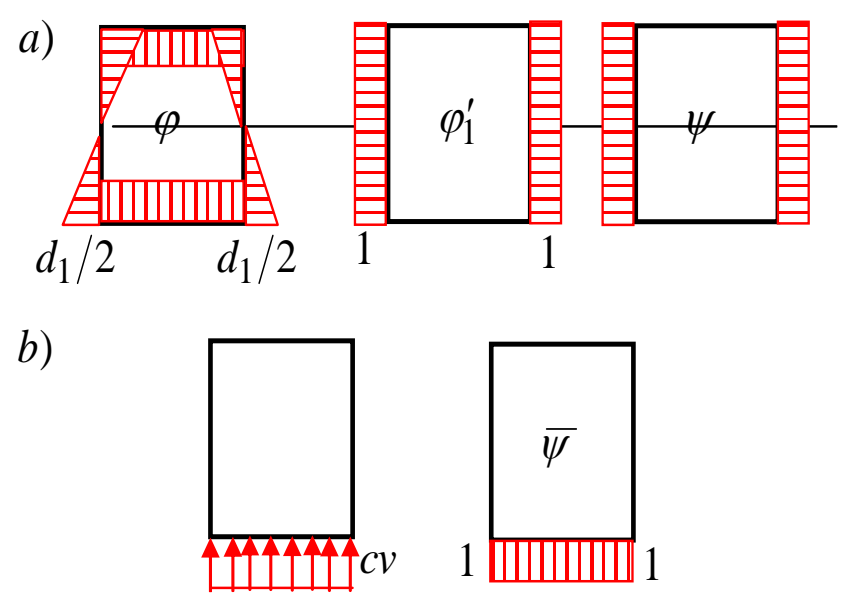

Рис. 10. Реакции упругого основания, равномерно распределенных по плоскости контакта оболочки с основанием 
Уравнения (I8) можно свести к одному уравнению через разрешающую функцию $F$, связанную с искомыми перемещениями следующими зависимостями:

$$
u=b F^{\prime} ; \quad v=a F^{\prime \prime}-b F .
$$

Непосредственной постановкой выражений (20) в уравнения (18) можно убедиться в том, что первое из этих уравнений удовлетворяется тождественно, а второе уравнение приводится к виду:

$$
F^{I V}-Q_{1}(z) F^{\prime \prime}+Q_{2}(z)=-\frac{Q}{a b} ;
$$

здесь

$$
Q_{1}(z)=\frac{\bar{Q}}{a b} ; \quad Q_{2}(z)=\frac{\bar{Q}}{a b}
$$

Учитывая отмеченные выше граничные условия, заданные на торцах оболочки, для решения уравнения (21) применим метод тригонометрических рядов, представив искомую функцию в виде:

$$
F=\sum A_{n} \cos \alpha_{n} z+\sum B_{m} \sin \alpha_{m} z
$$

Для определения постоянных $A_{n}$ и $B_{m}$ получим следующую систему алгебраических уравнений:

$$
\left.\begin{array}{c}
\int_{0}^{\ell / 2}\left[\sum A_{n}\left(\alpha_{n}^{4}+\alpha_{n}^{2} \bar{Q}_{1}(z)+\bar{Q}_{2}(z)\right) \cos \alpha_{n} z+\right. \\
\left.+\sum B_{m}\left(\alpha_{m}^{4}+\alpha_{m}^{2} \bar{Q}_{1}(z)+\bar{Q}_{2}(z)\right) \sin \alpha_{m} z\right] \cos \alpha_{i} z d z=-\frac{1}{a b} \int_{0}^{\ell / 2} Q \cos \alpha_{i} z d z ; \\
\left.+\sum B_{m}\left(\alpha_{m}^{4}+\alpha_{m}^{2} \bar{Q}_{1}(z)+\bar{Q}_{2}(z)\right) \sin \alpha_{m} z\right] \sin \alpha_{j} z d z=-\frac{1}{a b} \int_{0}^{\ell / 2} Q \sin \alpha_{j} z d z .
\end{array}\right\}
$$


Предположим, что коэффициент постели упругого основания изменяется вдоль оси z по закону:

$$
c(z)=c_{0}+c_{1} z+c_{2} \cos \frac{\pi z}{\ell}
$$

Ограничиваясь в рядах (23) первым тремя членами, перепишем уравнения (24) в следующем окончательном виде:

$$
\begin{aligned}
& A_{1}\left[\frac{\ell}{4} \alpha_{1}^{4}+\ell_{1}\left(c_{0} \frac{\ell}{4}-c_{1} \frac{\left(\pi^{4}-4\right) \ell^{2}}{16 \pi^{2}}+c_{2} \frac{2 \ell}{3 \pi}\right)\right]-A_{3}\left[\ell_{3}\left(c_{1} \frac{\ell^{2}}{4 \pi}-c_{2} \frac{2 \ell}{15 \pi}\right)\right]- \\
& -A_{5}\left[\ell_{5}\left(c_{1} \frac{\ell}{36 \pi^{2}}+c_{2} \frac{2 \ell}{105 \pi}\right)\right]+B_{2}\left[\frac{2 \ell \alpha_{2}^{4}}{3 \pi}+\ell_{2}\left(c_{0} \frac{2 \ell}{3 \pi}+c_{1} \frac{4 \ell^{2}}{9 \pi^{2}}-c_{2} \frac{\ell}{2 \pi}\right)\right]+ \\
& +B_{4}\left[\frac{4 \ell}{15 \pi} \alpha_{4}^{4}+\ell_{4}\left(c_{0} \frac{4 \ell}{15 \pi}-c_{1} \frac{8 \ell^{2}}{225 \pi^{2}}+c_{2} \frac{\ell}{12 \pi}\right)\right]+ \\
& +B_{6}\left[\frac{6 \ell}{35 \pi} \alpha_{6}^{4}+\ell_{6}\left(c_{0} \frac{6 \ell}{35 \pi}+c_{1} \frac{12 \ell^{2}}{1225 \pi^{2}}+c_{2} \frac{\ell}{6 \pi}\right)\right]=T_{1} ; \\
& A_{1}\left[\frac{2 \ell}{3 \pi} \alpha_{1}^{4}+\ell_{4}\left(c_{0} \frac{2 \ell}{3 \pi}+c_{1} \frac{2 \ell^{2}}{9 \pi^{2}}+c_{2} \frac{\ell}{2 \pi}\right)\right]-A_{3}\left[\frac{2 \ell}{5 \pi} \alpha_{3}^{2}+\ell_{3}\left(c_{0} \frac{2 \ell}{5 \pi}+\right.\right. \\
& \left.\left.+c_{1} \frac{12 \ell^{2}}{25 \pi^{2}}+c_{2} \frac{\ell}{6 \pi}\right)\right]-A_{5}\left[\frac{2 \ell}{21 \pi} \alpha_{5}^{4}+\ell_{5}\left(c_{0} \frac{2 \ell}{21 \pi}-c_{1} \frac{20 \ell^{2}}{441 \pi^{2}}+c_{2} \frac{11 \ell}{48 \pi}\right)\right]+ \\
& +B_{2}\left[\frac{\ell}{4} \alpha_{2}^{4}+\ell_{1}\left(c_{0} \frac{\ell}{4}+c_{1} \frac{\ell}{16}+c_{2} \frac{\ell}{2 \pi}\right)\right]-B_{4}\left[\ell_{4}\left(c_{1} \frac{\ell^{2}}{4 \pi^{2}}-c_{2} \frac{16 \ell}{105 \pi}\right)\right]-
\end{aligned}
$$




$$
\begin{aligned}
& -A_{1}\left[\ell_{1}\left(c_{1} \frac{\ell^{2}}{4 \pi^{2}}-c_{2} \frac{2 \ell}{15 \pi}\right)\right]+A_{3}\left[\frac{\ell}{4} \alpha_{3}^{4}+\ell_{3}\left(c_{0} \frac{\ell}{4}+c_{1} \frac{\left(9 \pi^{2}-4\right) \ell^{2}}{144 \pi^{2}}+\right.\right. \\
& \left.\left.+c_{2} \frac{18 \ell}{35 \pi}\right)\right]-A_{5}\left[\ell_{5}\left(c_{1} \frac{\ell^{2}}{4 \pi^{2}}-c_{2} \frac{10 \ell}{63 \pi}\right)\right]-B_{2}\left[\frac{2 \ell}{5 \pi} \alpha_{2}^{4}+\ell_{2}\left(c_{0} \frac{2 \ell}{5 \pi}+\right.\right. \\
& \left.\left.+c_{1} \frac{12 \ell^{2}}{25 \pi^{2}}+c_{2} \frac{\ell}{6 \pi}\right)\right]+B_{4}\left[\frac{4 \ell}{7 \pi} \alpha_{4}^{4}+\ell_{4}\left(c_{0} \frac{4 \ell}{7 \pi}-c_{1} \frac{24 \ell^{2}}{49 \pi^{2}}+c_{2} \frac{\ell}{3 \pi}\right)\right]+ \\
& +B_{6}\left[\frac{2 \ell}{9 \pi} \alpha_{6}^{4}+\ell_{6}\left(c_{0} \frac{2 \ell}{9 \pi}-c_{1} \frac{4 \ell^{2}}{81 \pi^{2}}+c_{2} \frac{3 \ell}{10 \pi}\right)\right]=T_{3} \\
& A_{1}\left[\frac{4 \ell}{15 \pi} \alpha_{1}^{4}+\ell_{1}\left(c_{0} \frac{4 \ell}{15 \pi}-c_{1} \frac{8 \ell^{2}}{225 \pi^{2}}+c_{2} \frac{\ell}{12 \pi}\right)\right]+A_{3}\left[\frac{4 \ell}{7 \pi} \alpha_{3}^{2}+\ell_{3}\left(c_{0} \frac{4 \ell}{7 \pi}+\right.\right. \\
& \left.\left.+c_{1} \frac{24 \ell^{2}}{49 \pi^{2}}+c_{2} \frac{\ell}{3 \pi}\right)\right]-A_{5}\left[\frac{4 \ell}{9 \pi} \alpha_{5}^{4}+\ell_{5}\left(c_{0} \frac{4 \ell}{9 \pi}+c_{1} \frac{40 \ell^{2}}{81 \pi^{2}}+c_{2} \frac{\ell}{5 \pi}\right)\right]- \\
& -B_{2}\left[\ell_{2}\left(c_{1} \frac{2 \ell^{2}}{9 \pi^{2}}-c_{2} \frac{16 \ell}{105 \pi}\right)\right]+B_{4}\left[\frac{\ell}{4} \alpha_{4}^{4}+\ell_{4}\left(c_{0} \frac{\ell}{4}+c_{1} \frac{\ell^{2}}{16 \pi^{2}}+c_{2} \frac{32 \ell}{63 \pi}\right)\right]- \\
& -B_{6}\left[\ell_{6}\left(c_{1} \frac{6 \ell^{2}}{25 \pi^{2}}-c_{2} \frac{16 \ell}{99 \pi}\right)\right]=T_{4} \\
& -A_{1}\left[\ell_{1}\left(c_{1} \frac{\ell^{2}}{36 \pi^{2}}+c_{2} \frac{2 \ell}{105 \pi}\right)\right]-A_{3}\left[\ell_{3}\left(c_{1} \frac{\ell^{2}}{4 \pi^{2}}-c_{2} \frac{10 \ell}{63 \pi}\right)\right]+A_{5}\left[\frac{\ell}{4} \alpha_{5}^{4}+\right. \\
& \left.+\ell_{5}\left(c_{0} \frac{\ell}{4}+c_{1} \frac{\left(25 \pi^{2}-2\right) \ell^{2}}{400 \pi^{2}}+c_{2} \frac{50 \ell}{99 \pi}\right)\right]-B_{2}\left[\frac{2 \ell}{21 \pi} \alpha_{2}^{4}+\right. \\
& \left.+\ell_{2}\left(c_{0} \frac{2 \ell}{21 \pi}+c_{1} \frac{\ell^{2}}{\pi^{2}}+c_{2} \frac{\ell}{6 \pi}\right)\right]-B_{4}\left[\frac{4 \ell}{9 \pi} \alpha_{4}^{4}+\left(c_{0} \frac{4 \ell}{9 \pi}+c_{1} \frac{40 \ell^{2}}{81 \pi^{2}}+\right.\right. \\
& \left.\left.+c_{2} \frac{\ell}{5 \pi}\right)\right]+B_{6}\left[\frac{6 \ell}{11 \pi} \alpha_{6}^{4}+\ell_{6}\left(c_{0} \frac{6 \ell}{11 \pi}+c_{1} \frac{60 \ell^{2}}{121 \pi^{2}}+c_{2} \frac{3 \ell}{10 \pi}\right)\right]=T_{5}
\end{aligned}
$$




$$
\begin{gathered}
A_{1}\left[\frac{6 \ell}{35 \pi} \alpha_{1}^{4}+\ell_{1}\left(c_{0} \frac{6 \ell}{35 \pi}+c_{1} \frac{12 \ell^{2}}{1225 \pi^{2}}+c_{2} \frac{\ell}{6 \pi}\right)\right]+A_{3}\left[\frac{2 \ell}{9 \pi} \alpha_{3}^{4}+\ell_{3}\left(c_{0} \frac{2 \ell}{9 \pi}-\right.\right. \\
\left.\left.-c_{1} \frac{36 \ell^{2}}{729 \pi^{2}}+c_{2} \frac{3 \ell}{10 \pi}\right)\right]+A_{5}\left[\frac{6 \ell}{11 \pi} \alpha_{5}^{4}+\ell_{5}\left(c_{0} \frac{6 \ell}{11 \pi}+c_{1} \frac{60 \ell^{2}}{121 \pi^{2}}+c_{2} \frac{3 \ell}{10 \pi}\right)\right]- \\
-B_{2}\left[\left(c_{2} \frac{8 \ell}{315 \pi}\right)\right]-B_{4}\left[\ell_{4}\left(c_{1} \frac{6 \ell^{2}}{25 \pi^{2}}-c_{2} \frac{16 \ell}{99 \pi}\right)\right]+ \\
+B_{6}\left[\frac{\ell}{4} \alpha_{6}^{4}+\ell_{6}\left(c_{0} \frac{\ell}{4}+c_{1} \frac{\ell^{2}}{16 \pi^{2}}+c_{2} \frac{72 \ell}{143 \pi}\right)\right]=T_{6} .
\end{gathered}
$$

где

$$
\begin{aligned}
& T_{1}=-\frac{Q}{a b} \int_{0}^{\ell / 2} \cos \frac{\pi z}{\ell} d z=-\frac{Q \ell}{\pi a b} ; \ell_{1}=\left(\alpha_{1}^{2} \frac{d_{2}}{b}+\frac{d_{2}}{a}\right) ; \alpha_{1}=\frac{\pi}{\ell} ; \\
& T_{2}=-\frac{Q}{a b} \int_{0}^{\ell / 2} \sin \frac{2 \pi z}{\ell} d z=-\frac{Q \ell}{\pi a b} ; \ell_{2}=\left(\alpha_{2}^{2} \frac{d_{2}}{b}+\frac{d_{2}}{a}\right) ; \alpha_{2}=\frac{2 \pi}{\ell} ; \\
& T_{3}=-\frac{Q}{a b} \int_{0}^{\ell / 2} \cos \frac{3 \pi z}{\ell} d z=\frac{Q \ell}{3 \pi a b} ; \ell_{3}=\left(\alpha_{3}^{2} \frac{d_{2}}{b}+\frac{d_{2}}{a}\right) ; \alpha_{3}=\frac{3 \pi}{\ell} ; \\
& T_{4}=-\frac{Q}{a b} \int_{0}^{\ell / 2} \sin \frac{4 \pi z}{\ell} d z=0 ; \ell_{4}=\left(\alpha_{4}^{2} \frac{d_{2}}{b}+\frac{d_{2}}{a}\right) ; \alpha_{4}=\frac{4 \pi}{\ell} ; \\
& T_{5}=-\frac{Q}{a b} \int_{0}^{\ell / 2} \cos \frac{5 \pi z}{\ell} d z=-\frac{Q \ell}{5 \pi a b} ; \ell_{5}=\left(\alpha_{5}^{2} \frac{d_{2}}{b}+\frac{d_{2}}{a}\right) ; \alpha_{5}=\frac{5 \pi}{\ell} ; \\
& T_{6}=-\frac{Q}{a b} \int_{0}^{\ell / 2} \sin o s \frac{6 \pi z}{\ell} d z=-\frac{Q \ell}{3 \pi a b} ; \ell_{6}=\left(\alpha_{6}^{2} \frac{d_{2}}{b}+\frac{d_{2}}{a}\right) ; \alpha_{6}=\frac{6 \pi}{\ell} .
\end{aligned}
$$

После определения шести постоянных $A_{1} ; A_{3} ; A_{5}$ и $B_{2} ; B_{4} ; B_{6}$ из системы уравнений (26) поставленная задача может считаться решенной, так как функция $F$ определяется из выражений (23), искомые перемещения из выражений (20), а напряжения оболочки могут быть вычеслены по формулам:

$$
\sigma(z, s)=E \sum_{i=1}^{m} u_{i}^{\prime}(z) \varphi_{i}(s)
$$




$$
\tau(z, s)=G\left[\sum_{i=1}^{m} u_{i}^{\prime} \varphi_{i}(s)+\sum_{k=1}^{n} v_{k}^{\prime}(z) \psi_{k}(s)\right]
$$

Обобщенные продольные и поперечные силы в сечении оболочки выражаются в виде:

$$
\begin{aligned}
& P(z)=\int \sigma(z, s) \varphi(s) \cdot d F . \\
& Q(s)=\int \tau(z, s) \psi(s) \cdot d F .
\end{aligned}
$$

В качестве примера рассмотрим оболочку с размерами $\delta_{1}=\delta_{2}=\delta=\frac{d}{10}$ и упругими постоянным $E=\gamma G ; \gamma=2,35$. Коэффициент постели упругого основания примем изменяющимся по закону

$$
c(z)=c_{0}+c_{2} \cos \frac{\pi z}{\ell}
$$

В силу симметрии задачи вдоль оси 7 , система алгебраических уравнений (26) будет содержать только три уравнения, которые примут следующий вид:

$$
\begin{gathered}
{\left[\frac{\pi^{4}}{4 \ell^{3}}+\frac{\ell_{1}}{4}\left(c_{0} \ell+c_{2} \frac{8 \ell}{3 \pi}\right)\right] A_{1}+\ell_{3} \frac{2}{15} c_{2} \ell A_{3}-\ell_{5} \frac{2}{105 \pi} c_{2} \ell A_{5}=T_{1}} \\
\ell_{1} \frac{2}{15 \pi} c_{2} \ell A_{1}+\left[\frac{81 \pi^{4}}{4 \ell^{3}}+\frac{\ell_{3}}{4}\left(c_{0} \ell+c_{2} \frac{72 \ell}{35 \pi}\right)\right] A_{3}+\ell_{5} \frac{10}{63 \pi} c_{2} \ell A_{5}=T_{3} ; \\
-\ell_{1} \frac{2}{105 \pi} c_{2} \ell A_{1}+\ell_{3} \frac{10}{63 \pi} c_{2} \ell A_{3}+\left[\frac{625 \pi^{4}}{4 \ell^{3}}+\frac{\ell_{5}}{4}\left(c_{0} \ell+c_{2} \frac{200 \ell}{99 \pi}\right)\right] A_{5}=T_{5} .
\end{gathered}
$$

Перемещения и напряжения оболочки определим для следующих случаев, характеризующих случаев, характеризующих жесткость основания: $c_{2}=0 ; c_{2}=0,5 c_{0} ; c_{2}=-0,5 c_{0} ;$ при различных отношениях длины оболочки к размеру ее поперечного сечения: $(\ell / d)=3,5,7,10$.

На рис. 11, 12 показаны значения вертикального перемещения $v$ и нормального напряжения $\sigma$ в нижней грани оболочки, относящиеся к среднему сечению оболочки $z=0$. 


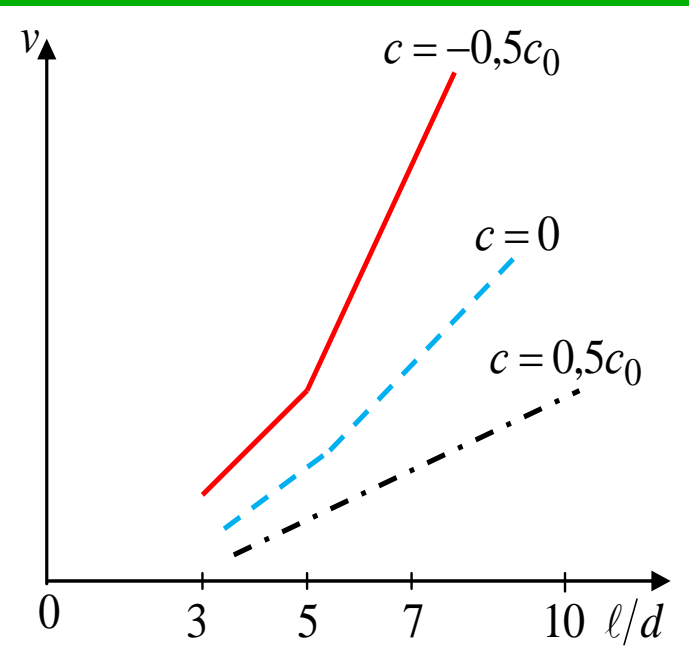

Рис. 11. Значения вертикального перемещения

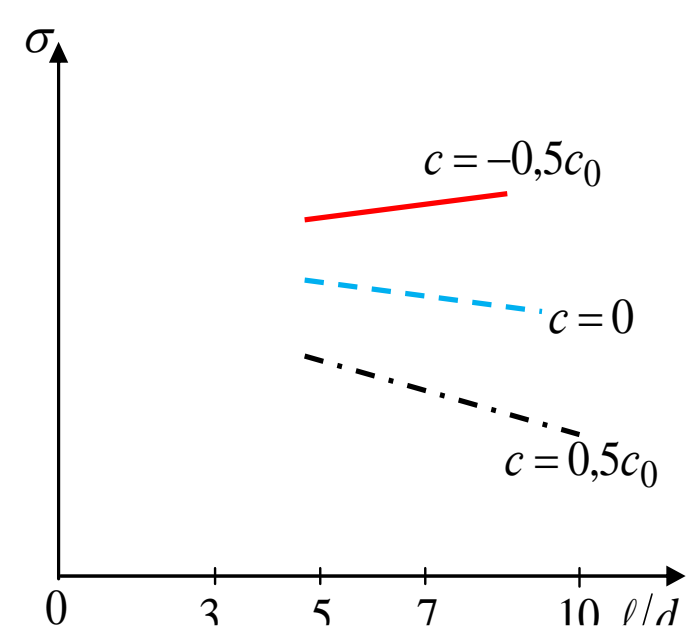

Рис. 12. Значения нормального напряжения

Из графиков, приведенных на рис. 13-18, можно видеть, что уже первый член ряда обеспечивает достаточно высокую точность вычислений: различие первого и третьего приближений для перемещений не превышает $1,97 \%$, а для напряжений 7,8\%. При этом точность повышается с уменьшением отношения $\ell / d:$ для $(\ell / d)=3$ ошибка не превышает $1,2 \%$.

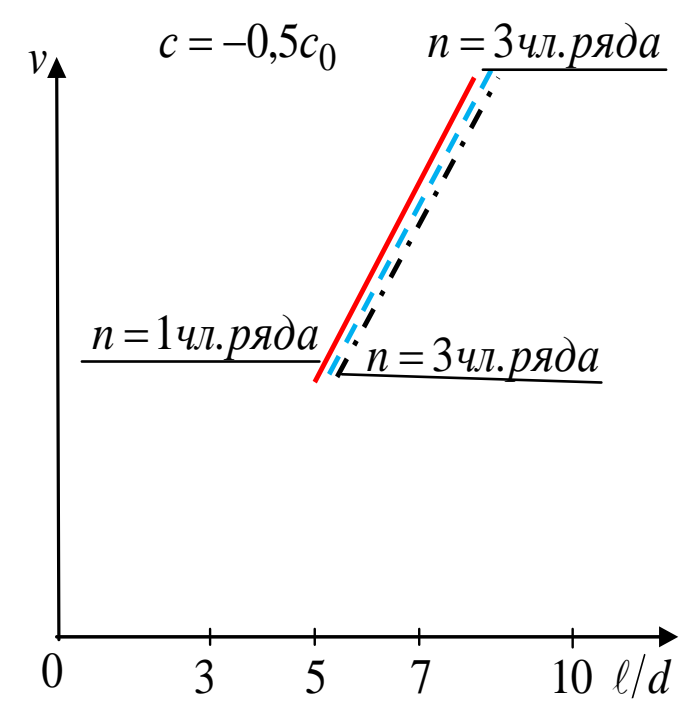

Рис. 13. Значения вертикального перемещения

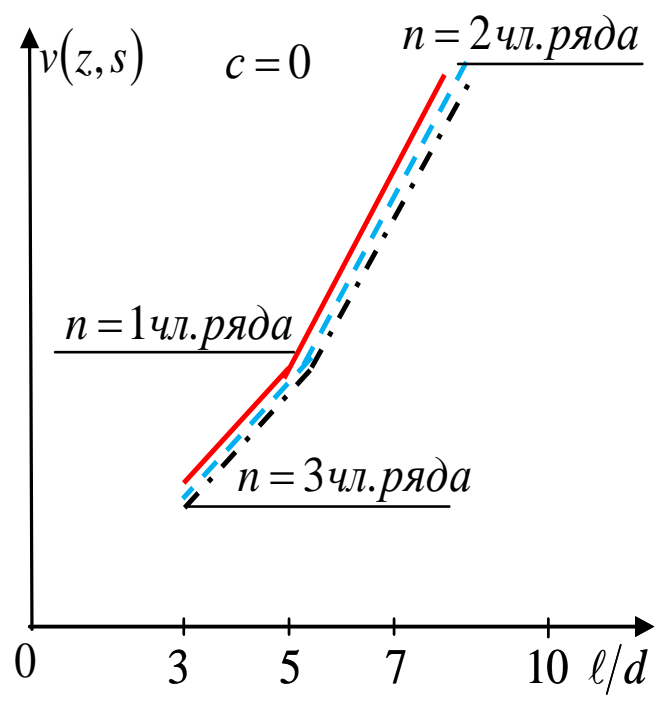

Рис. 14. Значения нормального напряжения 


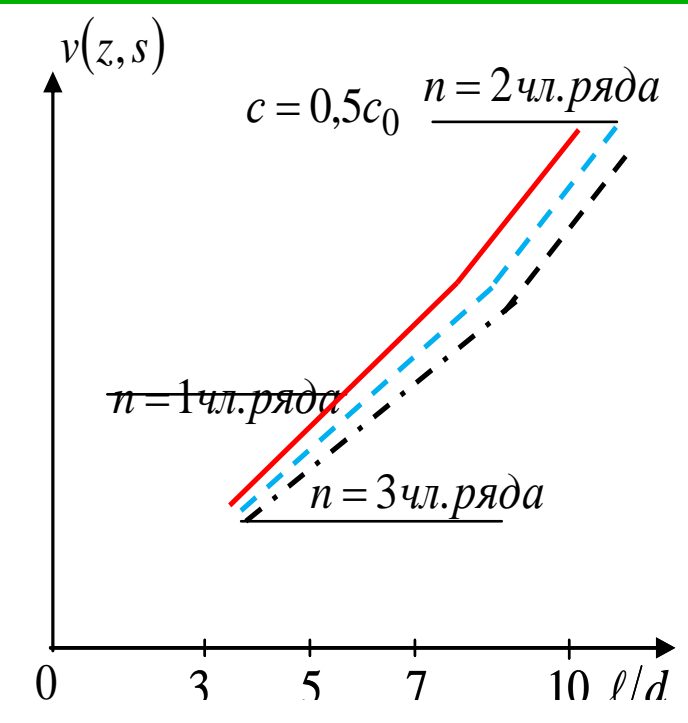

Рис. 15. Значения вертикального перемешения

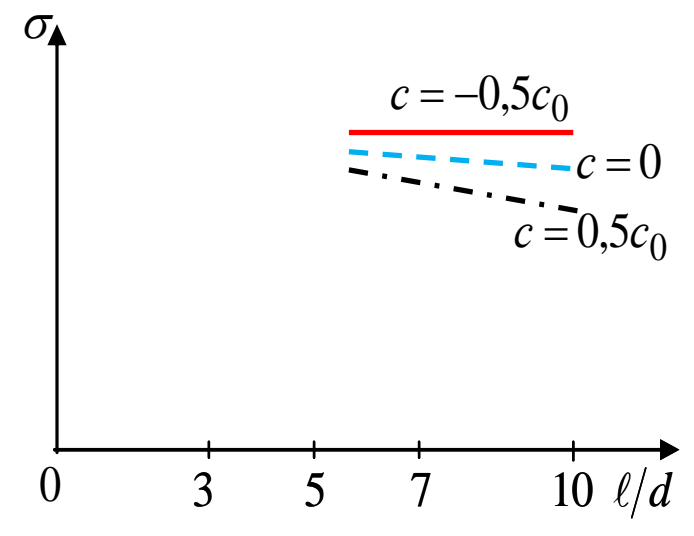

Рис. 17. Значения вертикального перемещения

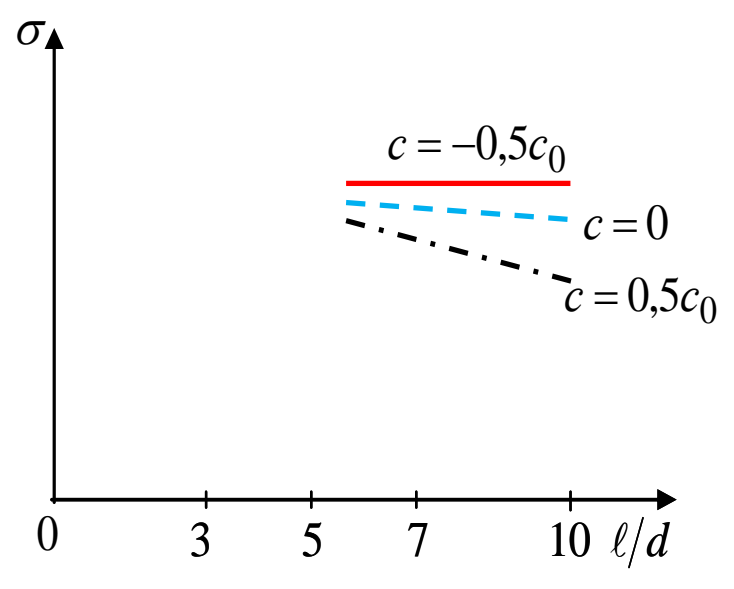

Рис. 16. Значения нормального напряжения

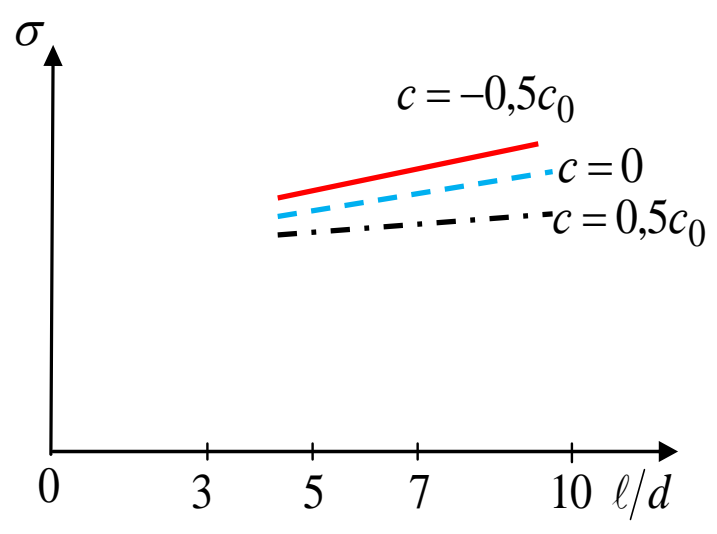

Рис. 18. Значения нормального напряжения

Графики, приведенные на рис.11 и 12, показывают, что неоднородность основания по длине оболочки существенно влияет на ее прогиб и напряженное состояние. Основание, ослабленное в средней части оболочки $\left(c_{2}=-0,5 c_{0}\right)$, приводит к возрастанию перемещений и напряжений, а основание, уплотненное в средней части $\left(c_{2}=-0,5 c_{0}\right)$, вызывает обратный эффект, возрастающий с увеличением длины оболочки. При этом увеличение длины оболочки не 
вызывает существенного возрастания напряжений $\sigma$ в случае основания с постоянным коэффициентом постели $\left(c_{2}=0\right)$.

Сопоставление полученных результатов с аналогичными результатами для балки такого же поперечного сечения показывает, что прогиб балки оказывается меньше примерно на 10\%, чем прогиб оболочки, что объясняется учетом деформаций сдвига в оболочке.

\section{3. Кручение односвязной призматической оболочки на неоднородном}

\section{упругом основании}

Если нагрузка на призматическую оболочку не является симметричной относительно вертикальной плоскости, проходящей через продольную ось, то конструкция будет подвергаться кручению. Такой вид деформации часто возникает в практике эксплуатации.

Рассмотрим односвязную призматическую оболочку, расположенную на упругом основании винклеровского типа (рис. 19). Будем предполагать, что коэффициент постели упругого основания является известной функцией координаты z, а оболочка находится под действием нагрузки, вызывающей кручение. Предположим также, что торцы оболочки оперты на жесткие в своей плоскости и гибкие из плоскости диафрагмы.

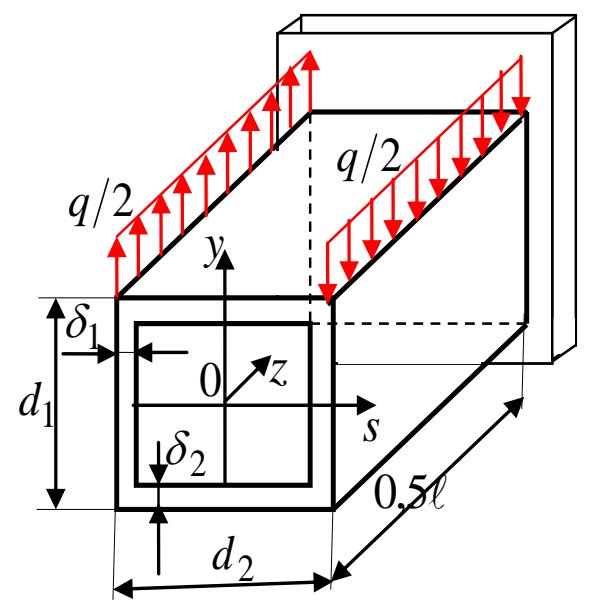

Рис. 19. Оснавание Винклера 289 
Для решения поставленной задачи, как и в предыдущих примерах, применим вариационный метод В.З. Власова, для чего представим искомые перемещения в виде разложений (17). Учитывая, что действующая нагрузка будет вызывать депланацию, кручение и деформацию контура, координатные функции выберем в виде, представленном на рис. 20. При этом дифференциальные уравнения, характеризующие условия равновесия призматической оболочки, запишутся в виде:

$$
\begin{gathered}
\gamma a_{44} u_{4}^{\prime \prime}-b_{44} u_{4}-c_{44} v_{4}^{\prime}=0 ; \quad r_{11} v_{1}^{\prime \prime}-\bar{Q}_{1} v_{1}-\bar{Q}_{4} v_{4}+Q_{1}=0 ; \\
c_{44} u_{4}^{\prime}+r_{44} v_{4}^{\prime \prime}-\gamma_{44} v_{4}-\bar{Q}_{1} v_{1}-\bar{Q}_{4} v_{4}+Q_{4}=0 .
\end{gathered}
$$

где

$$
\begin{gathered}
a=a_{44}=\frac{E}{G} \int_{s} \varphi_{4} \varphi_{4} \delta d s=\frac{d_{1}^{3} d_{2}^{2}}{24} \delta_{1}+\frac{d_{1}^{2} d_{2}^{3}}{24} \delta_{2} ; \\
b=b_{44}=\frac{E}{G} \int_{s} \varphi_{4}^{\prime} \varphi_{4}^{\prime} \delta d s=\frac{d_{1}^{2} d_{2}}{2} \delta_{1}+\frac{d_{1} d_{2}^{2}}{2} \delta_{2} ; \\
c_{44}=\int_{s} \psi_{4} \varphi_{4}^{\prime} \delta d s=\frac{d_{1}^{2} d_{2}}{2} \delta_{1}+\frac{d_{1} d_{2}}{2} \delta_{2} ; \\
r_{44}=\int_{s} \psi_{4} \psi_{4} \delta d s=\frac{d_{1}^{2} d_{2}}{2} \delta_{1}+\frac{d_{1} d_{2}}{2} \delta_{2} ; \\
s=s_{44}=\frac{1}{E} \int_{s} \frac{M}{E I} d s=\frac{d_{1}^{2}}{2000}+\frac{d_{2}}{200}=\frac{d^{2}}{1000} . \\
\bar{Q}_{1}=\bar{Q}_{4}=\frac{1}{G} \int_{s} c(z) \bar{\psi}(s)=\frac{d_{2}^{3}}{24 G} c(z) ; \quad Q_{1}=Q_{4}=\frac{1}{G} \int_{s} q(z) \bar{\psi}(s)=\frac{d_{2}}{2 G} q(z) .
\end{gathered}
$$

Коэффициентами $\bar{Q}_{1}$ и $\bar{Q}_{4}$ входящими в формулы (36), представлена работа реакций упругого основания, линейно распределенных по плоскости контакта оболочки с основанием (рис.20, $b$ ).

Рассмотрим случая, когда $q=q(z)=$ const. Для решения системы уравнений (34) применим метод тригонометрических рядов. 
В соответствии с заданными граничными условиями представим искомые функции $u_{4}(z) ; v_{1}(z) ; v_{4}(z)$ и нагрузку $q=$ const в следующем виде:

$$
\begin{aligned}
& u_{4}(z)=\sum_{n=1}^{\infty} u_{n 4} \sin \frac{n \pi z}{\ell} ; \quad v_{1}(z)=\sum_{n=1}^{\infty} v_{n 1} \cos \frac{n \pi z}{\ell} \\
& v_{4}(z)=\sum_{n=1}^{\infty} v_{n 4} \cos \frac{n \pi z}{\ell} ; \quad q(z)=\frac{4 q}{\pi} \sum \frac{1}{n} \cos \frac{n \pi z}{\ell} .
\end{aligned}
$$
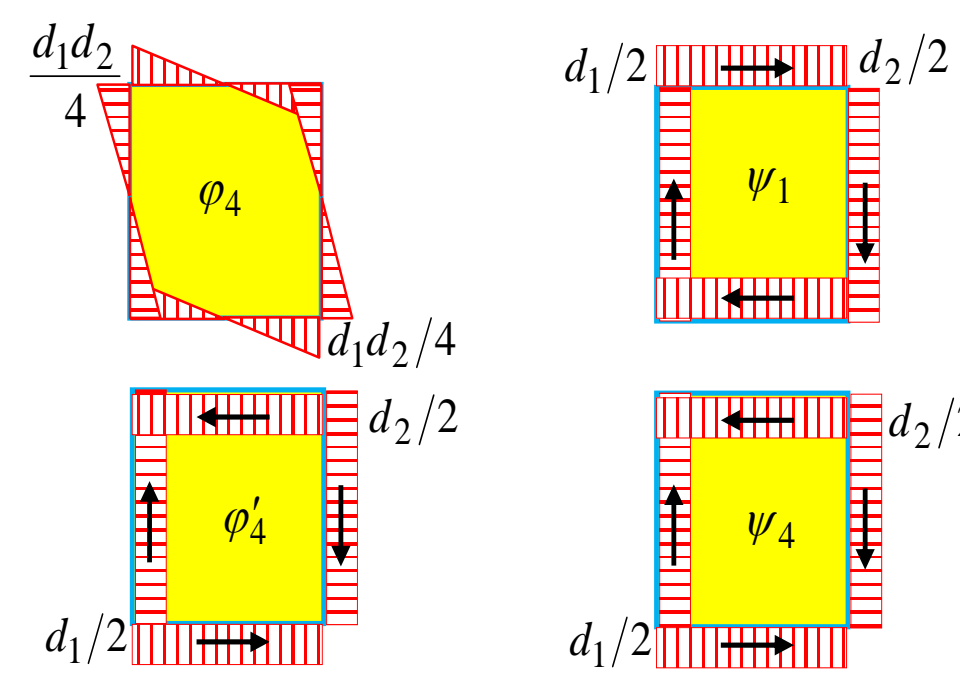

b)
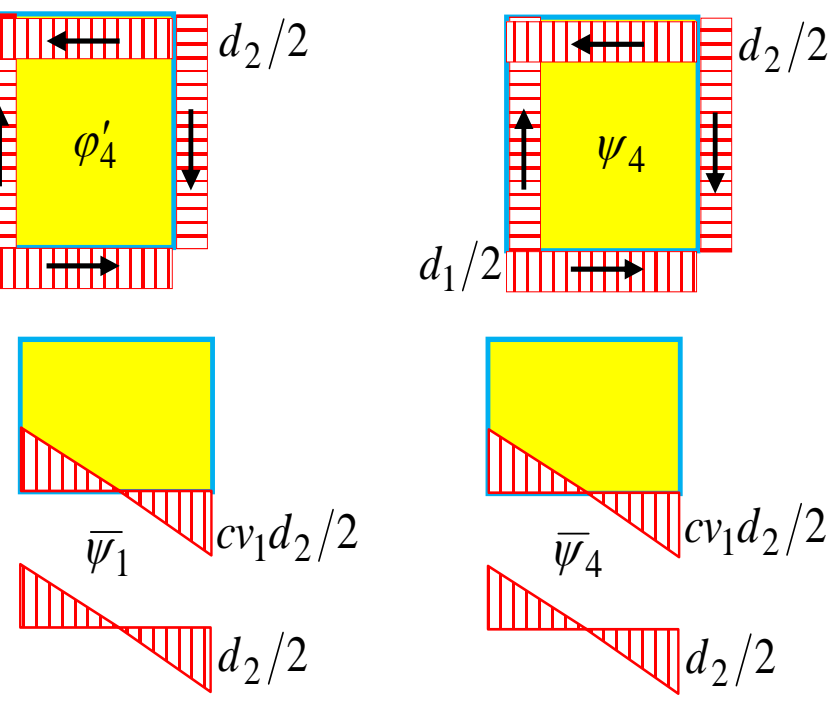

Рис. 20. Реакции упругого основания, линейно распределенных по Плоскости контакта оболочки с основанием

Для определения коэффициентов $u_{n 4} ; v_{n 1}$ и $v_{n 4}$ получим при этом следующие системы алгебраических уравнений: 


$$
\begin{gathered}
\int_{0}^{\ell / 2} \sum_{n=1}^{\infty}\left\{\left[-\left(\frac{n \pi}{\ell}\right)^{2}-b\right] u_{n 4}+b\left(\frac{n \pi}{\ell}\right) v_{n 1}\right\} \sin \frac{n \pi z}{\ell} \sin \frac{k \pi z}{\ell} d z=0 ; \\
\int_{0}^{\ell / 2} \sum_{n=1}^{\infty}\left\{\left[b\left(\frac{n \pi}{\ell}\right)^{2}+\bar{Q}_{1}\right] v_{n 1}+\bar{Q}_{4} v_{n 4}\right\} \cos \frac{n \pi z}{\ell} \cos \frac{k \pi z}{\ell} d z= \\
=\int_{0}^{\ell / 2} \frac{4 q}{\pi G} \sum_{n=1}^{\infty} \frac{1}{n} \cos \frac{n \pi z}{\ell} \cos \frac{k \pi z}{\ell} d z ; \\
\int_{0}^{\ell / 2} \sum_{n=1}^{\infty}\left\{\left[b\left(\frac{n \pi}{\ell}\right) u_{n 4}-\bar{Q}_{1} v_{n 1}\right]-\left[(s+) \bar{Q}_{4}\right]+b\left(\frac{n \pi}{\ell}\right)^{2} v_{n 4}\right\} \times \\
\times \cos \frac{n \pi z}{\ell} \cos \frac{k \pi z}{\ell} d z=\int_{0}^{\ell / 2}\left(-\frac{4 q}{\pi G} \sum_{n=1}^{\infty} \frac{1}{n} \cos \frac{n \pi z}{\ell}\right) \cos \frac{k \pi z}{\ell} d z .
\end{gathered}
$$

Предположим, что коэффициент постели упругого основания изменяется вдоль оси z по закону:

$$
c(z)=c_{0}+c \cos \frac{k \pi z}{\ell}
$$

Ограничиваясь в рядах (37) первыми тремя членами, перепишем уравнения (38) в окончательном виде:

$$
\begin{aligned}
& \left(\gamma a \alpha_{1}^{2} \frac{\ell}{4}+b \frac{\ell}{4}\right) u_{14}+b \alpha_{1} \frac{\ell}{4} v_{14}=0 ; \quad\left(\gamma a \alpha_{3}^{2} \frac{\ell}{4}+b \frac{\ell}{4}\right) u_{34}+b \alpha_{3} \frac{\ell}{4} v_{34}=0 \\
& \left(\gamma a \alpha_{5}^{2} \frac{\ell}{4}+b \frac{\ell}{4}\right) u_{54}+b \alpha_{5} \frac{\ell}{4} v_{54}=0 ; \\
& \left(b \alpha_{1}^{2} \frac{\ell}{4}+\frac{d^{3} \ell}{48} c_{0}+\frac{d^{3} \ell}{36 \pi} c\right) v_{11}+\frac{d^{3} \ell}{60 \pi} c v_{31}-\frac{d^{3} \ell}{252 \pi} c v_{51}+ \\
& +\left(\frac{d^{3} \ell}{48} c_{0}+\frac{d^{3} \ell}{36 \pi} c\right) v_{14}+\frac{d^{3} \ell}{60 \pi} c v_{34}-\frac{d^{3} \ell}{252 \pi} c=\frac{d \ell}{2 \pi G} q
\end{aligned}
$$




$$
\begin{gathered}
\frac{d^{3} \ell}{60 \pi} c v_{11}+\left(b \alpha_{3}^{2} \frac{\ell}{4}+\frac{d^{3} \ell}{48} c_{0}+\frac{17 d^{3} \ell}{420 \pi} c\right) v_{31}+\frac{11 d^{3} \ell}{756 \pi} c v_{51}+ \\
\frac{d^{3} \ell}{60 \pi} c v_{14}+\left(\frac{d^{3} \ell}{48} c_{0}+\frac{17 d^{3} \ell}{420 \pi} c\right) v_{34}+\frac{11 d^{3} \ell}{756 \pi} c v_{54}=\frac{d \ell}{6 \pi G} q \\
-\frac{d^{3} \ell}{252 \pi} c v_{11}+\frac{11 d^{3} \ell}{756 \pi} c v_{31}+\left(b \alpha_{5}^{2} \frac{\ell}{4}+\frac{d^{3} \ell}{48} c_{0}+\frac{49 d^{3} \ell}{1188 \pi} c\right) v_{51}- \\
-\frac{d^{3} \ell}{252 \pi} c v_{41}+\frac{11 d^{3} \ell}{756 \pi} c v_{34}+\left(\frac{d^{3} \ell}{48} c_{0}+\frac{49 d^{3} \ell}{1188 \pi} c\right) v_{54}=\frac{d \ell}{10 \pi G} q \\
b \frac{\alpha_{1} \ell}{4} u_{14}+\left(\frac{d^{3} \ell}{48} c_{0}+\frac{d^{3} \ell}{36 \pi} c\right) v_{11}+\frac{d^{3} \ell}{60 \pi} c v_{31}-\frac{d^{3} \ell}{252 \pi} c v_{51}+ \\
+\left(b \alpha_{1}^{2} \frac{\ell}{4}+\gamma s \frac{\ell}{4}+\frac{d^{3} \ell}{48} c_{0}+\frac{d^{3} \ell}{36 \pi} c\right) v_{41}+\frac{d^{3} \ell}{60 \pi} c v_{34}-\frac{d^{3} \ell}{252 \pi} c v_{51}=\frac{d \ell}{2 \pi G} q \\
b \frac{\alpha_{3} \ell}{4} u_{34}+\frac{d^{3} \ell}{60 \pi} c v_{11}+\left(\frac{d^{3} \ell}{48} c_{0}+\frac{17 d^{3} \ell}{420 \pi} c\right) v_{31}+\frac{11 d^{3} \ell}{756 \pi} c v_{51}+ \\
+\frac{d^{3} \ell}{60 \pi} c v_{14}+\left(b \alpha_{3}^{2} \frac{\ell}{4}+\gamma s \frac{\ell}{4}+\frac{d^{3} \ell}{48} c_{0}+\frac{17 d^{3} \ell}{420 \pi} c\right) v_{34}+\frac{11 d^{3} \ell}{756 \pi} c v_{54}=\frac{d \ell}{2 \pi G} q \\
b \alpha_{5} \frac{\ell}{4} u_{54}-\frac{d^{3}}{252 \pi} c \ell v_{11}+\frac{11 d^{3}}{756 \pi} c \ell v_{31}+\left(\frac{d^{3} \ell}{48} c_{0}+\frac{49 d^{3}}{1188 \pi} \ell c\right) v_{51}- \\
-\frac{d^{3} \ell}{252 \pi} c v_{14}+\frac{11 d^{3} \ell}{756 \pi} c v_{34}+\left(b \alpha_{5}^{2} \frac{\ell}{4}+\gamma s \frac{\ell}{4}+\frac{d^{3} \ell}{48} c_{0}+\frac{49 d^{3} \ell}{1188 \pi} c\right) v_{54}=\frac{d \ell}{10 \pi G} q
\end{gathered}
$$

После решения системы алгебраических уравнений (39) и определения коэффициентов $u_{n 4} ; v_{n 1} ; v_{n 4}$; напряжения призматической оболочки могут быть найдены по известным формулам:

$$
\begin{gathered}
\sigma(z, s)=E \sum_{i=1}^{m} u_{i}^{\prime}(z) \varphi_{i}(s) . \\
\tau(z, s)=G\left[\sum_{i=1}^{m} u_{i}^{\prime} \varphi_{i}(s)+\sum_{k=1}^{n} v_{k}^{\prime}(z) \psi_{k}(s)\right] .
\end{gathered}
$$


В качестве примера ниже рассмотрена оболочка с размерами $\delta_{1}=\delta_{2}=\delta=\frac{d}{10}$ и упругими постоянными $E=\gamma G ; \gamma=2,35 . E=2,4 \cdot 10^{6} \mathrm{~N} / \mathrm{sm}^{2}$.

Перемещения и напряжения оболочки определены для следующих случаев, характеризующих жесткость основания $c \ell=0 ; c \ell=0,5 c_{0} ; c \ell=-0,5 c_{0}$; при различных отношениях длины оболочки к размеру ее поперечного сечения: $(\ell / d)=1,5 ; 3 ; 5 ; 7 ; 10$.

Вычисления проводились на ЭВМ ЕС-1022 при удержании в рядах (37) одного, двух и трех членов.

На рис. 21, 22 показаны соответственно значения горизонтального перемещения ребра и касательных напряжений $\tau$ в торцевом сечении $z=(\ell / d)$ оболочки.

a)

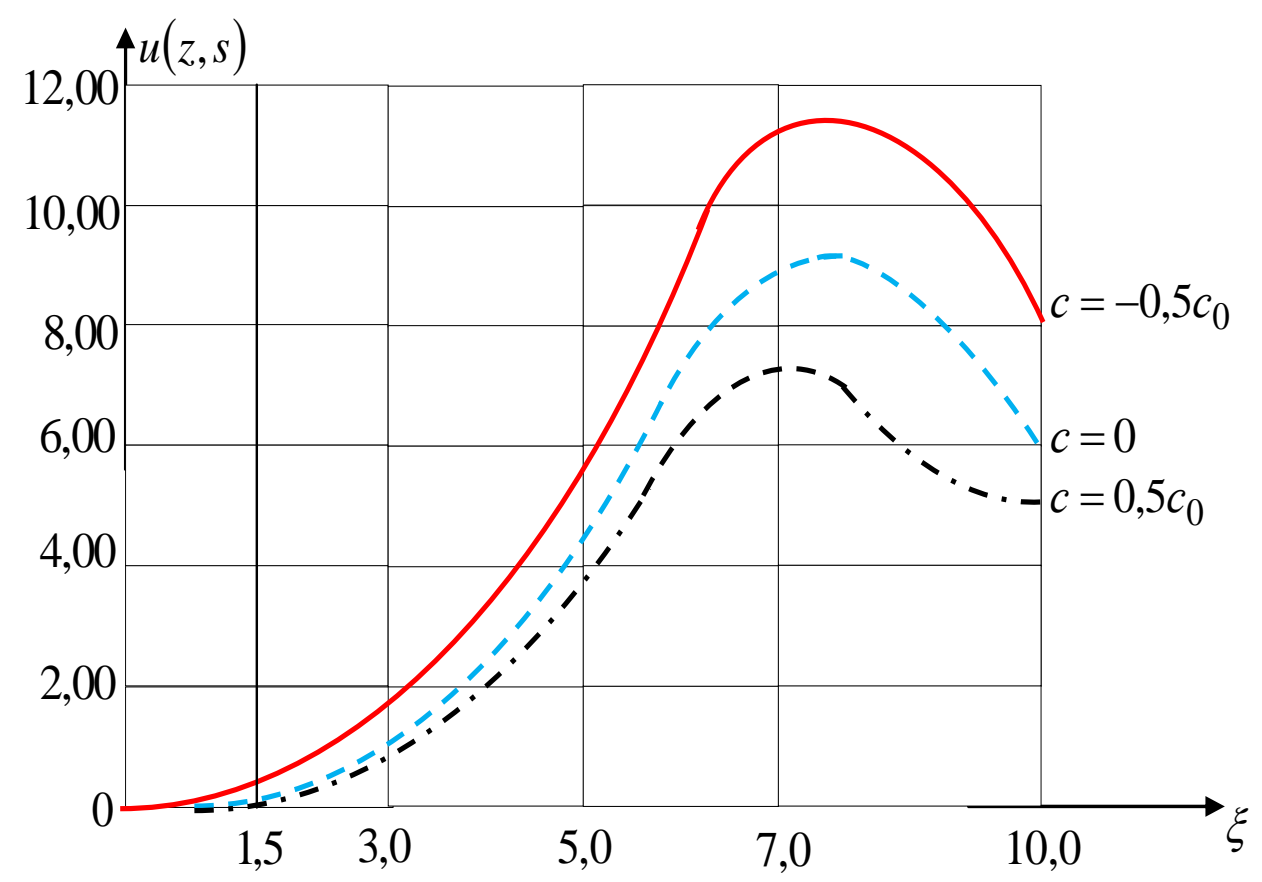

Рис. 21. Горизонтальное перемещение ребра и касательных напряжений $\tau$ в торцевом сечении $z=(\ell / d)$ оболочки. 


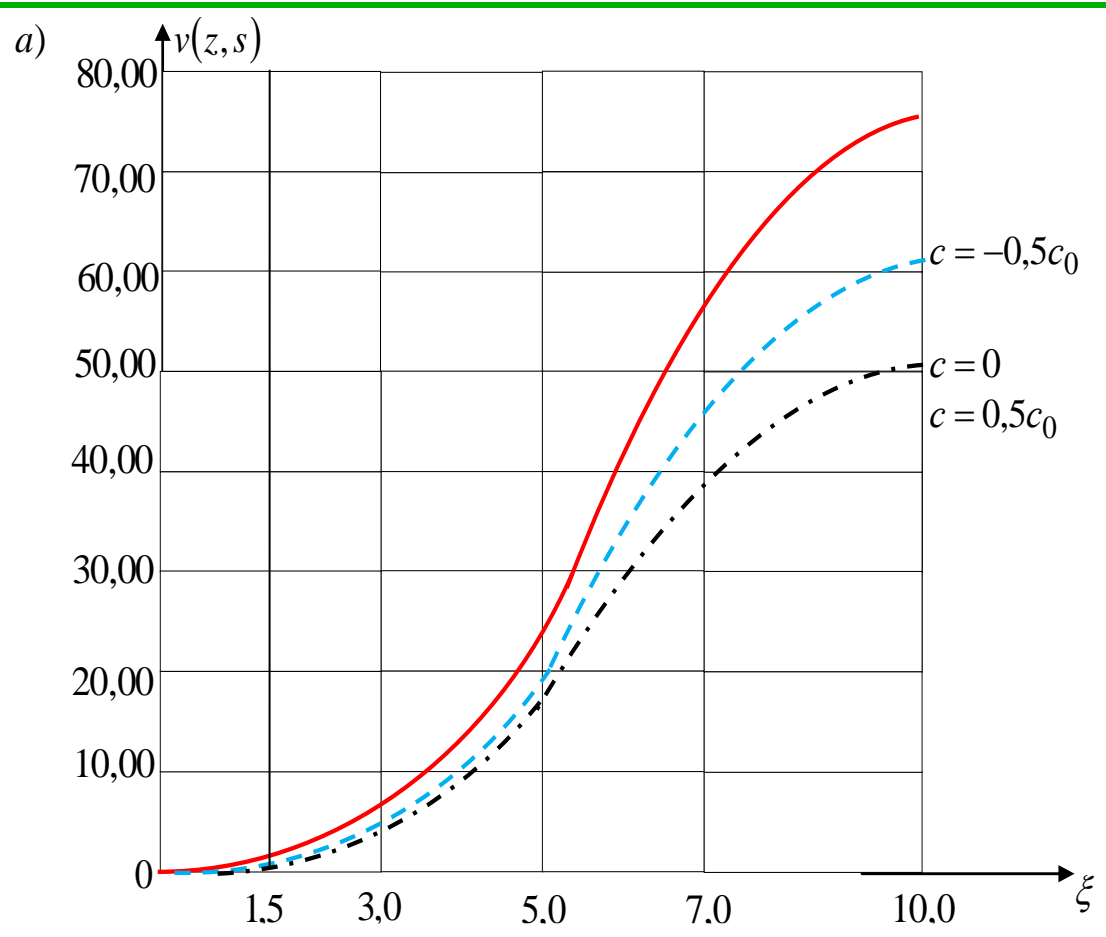

Рис. 22. Горизонтальное перемещение ребра и касательных напряжений $\tau$ в торцевом сечении $z=(\ell / d)$ оболочки.

На рис. 23, 24 приведены значения вертикального перемещения ребра и нормального напряжения в ребре оболочки для ее среднего сечения $z=0$.

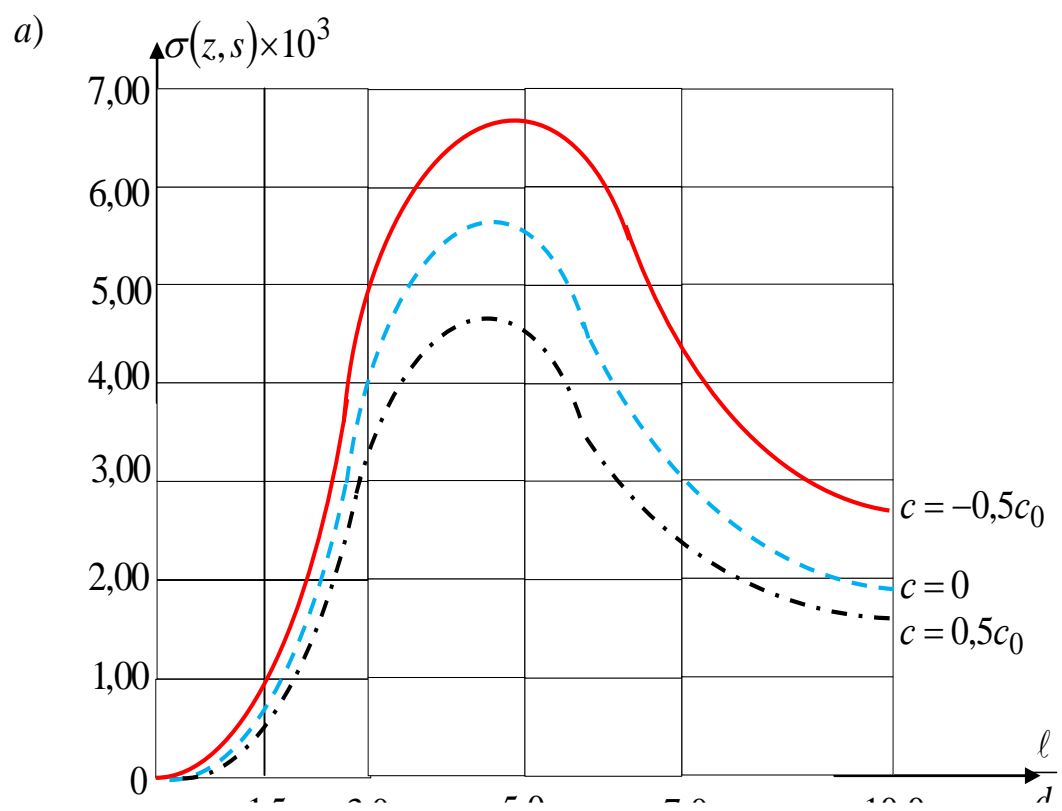

Рис. 23. Вертикальное перемещение ребра и нормального напряжения в ребре оболочки для ее среднего сечения $z=0$. 


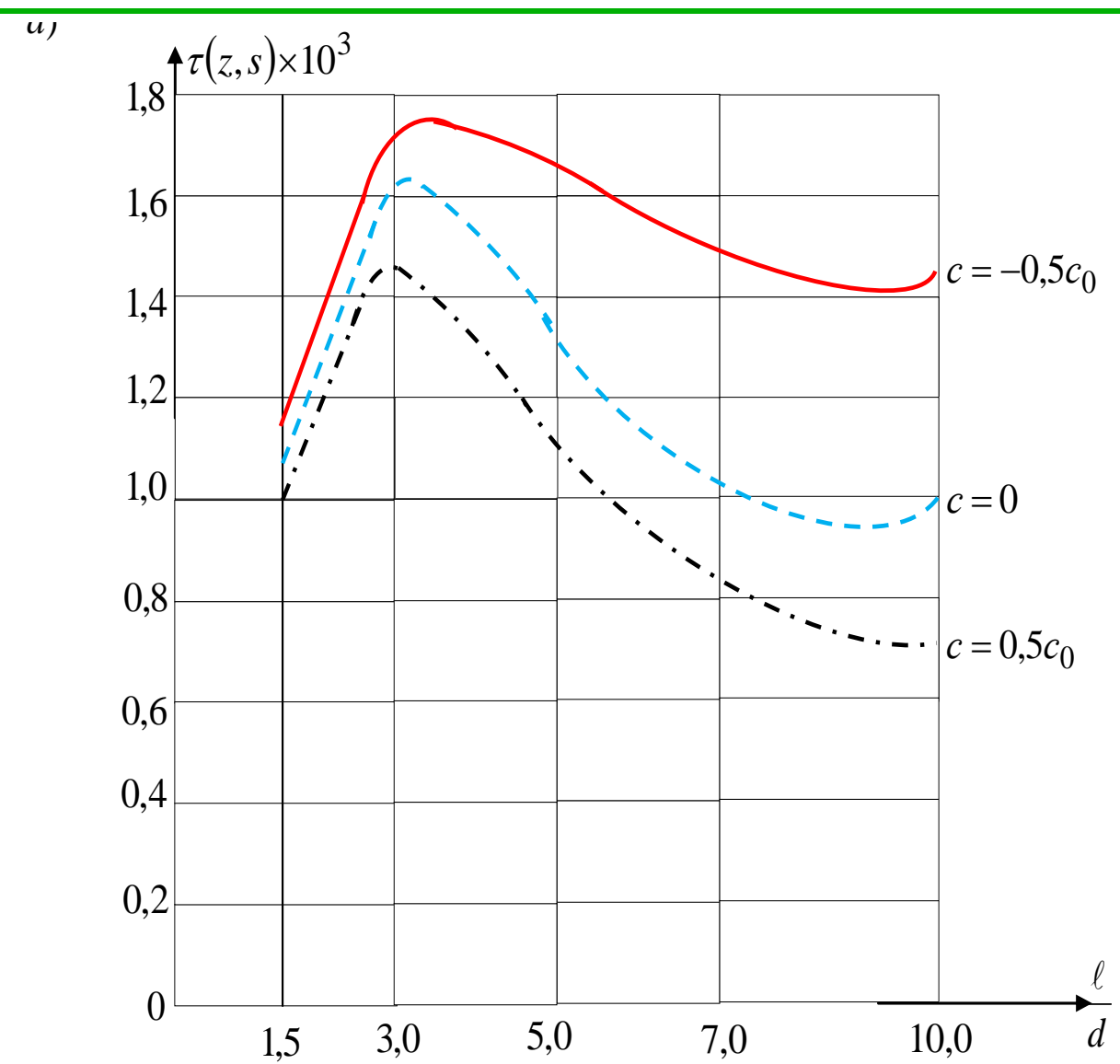

Рис. 24. Вертикальное перемещение ребра и нормального напряжения в ребре оболочки для ее среднего сечения $z=0$.

Из приведенных графиков можно видеть, что с ростом отношения вертикальные перемещения непрерывно возрастают. В то же время горизонтальные перемещения и напряжения и $\sigma$ и $\tau$ достигают своего максимума при отношениях $\ell / d$ в пределах $3-5$.

\section{Заключение}

Установлено, что учет неоднородности (детерминированной или случайной) основания существенно влияет на напряженно-деформированное состояние оболочки, причем учет неоднородности в статистическом смысле позволяет снизить расчетные значения усилий. 


\section{Список литературы}

1. Власов В.3. Тонкостенные пространственные системы.-М.: Гоостройиздат, 1958.-502 с.

2. Власов В.3., Леонтьев Н.Н. Техническая теория расчета фундаментов на упругом основании.-Тр.МИСИ, 1956, Сб. В 14, 12-31 с.

3. Соболев Д.Н. Применение теории случайных функций к решению некоторых контактных задач.- П Всесоюзный съезд по теоретической и прикладной механике. Сб.тезисов.-М.: 1964.

4. Соболев Д.Н., Насонкин В.Д. О распределении напряжений в статистически неоднородной упругой полуплоскости. - В кн.: Проблемы надежности в строительной механике. - Вильнос, 1968, с. 148-150.

5. Ismayilov K., Karimova K. Application of used automobile tires granules for road construction in Uzbekistan. Journal of Critical Reviews, 2020. V.7, No12, pp 946-948. DOI: 10.31838/jcr.07.12.165.

6. Kubaymurodov D.I., Ismayilov K., Ibragimov A. Application of the Bubnov-Galerkin method to determine the statistical characteristics of the state of a prismatic shell. Prospective research solutions collection of articles of the IIIInternational Scientific and Technical Competition. p. 1131212021 Petrozavodsk https://www.elibrary.ru/item.asp?id=44587093. DOI: 10.46916 / 22012021-3-978-500174-117-6.

7. Ismayilov K. Critical strains and critical stresses in the steel rod beyond the elastic limit. European Science Review. 2018, № № 5-6.

8. Ismayilov K., Karimova K. The Impact of Automobile Tires on the Environment from the Period of Raw Materials to Their Disposal, Retrieval Volume8 Issue-3, September 2019. Number: C4473098319/19 @ BEIESP DOI:10.35940/ijrte.C4473.098319.

9. Ismayilov K., Suleymanov A., Toshev S., Ruziev S. Option of the Method of Successive Approximations in Calculating the Epicenters of Extreme and Emergency Situations. Ilkogretim Online - Elementary Education Online, 2021; 20 
(3): pp. 1640-1647 http://ilkogretim-online.org doi: 10.17051/ilkonline.2021.03.186.

10. Mavlonov T., Yuldoshev B., Ismayilov K., Toshev S. Compressed rectangular plates stability beyond the elastic limit. IOP Conference Series: Materials Science and Engineering. 2020. DOI:10.1088/1757-899X/883/1/012199.

11. Ismayilov K. Stability of compressed rods, plates and shells beyond the elastic limit. FAN. Samarkand, 2003, p. 280.

12. Ismayilov K., Suleymanov S.T., Ruziev S.T., Aripjanova M.B. A new method of successive approximations when calculating elements of electromechanical machines.XXI Century. Technosphere Safety. 2020; 5(2):168-172. (In Russ.) https://doi.org/10.21285/2500-1582-2020-2-168-172.

13. Ismayilov $K$. On the stability of a compressed bar beyond elasticity nternational Congress. Spatial structures in new construction during the reconstruction of buildings and structures. MKPK98. Moscow 1998.p.46.

14. Ismayilov K. Stress strain state of a circular plate beyond the elastic limit. Innovative discourse of the development of modern science and technology. Collection of articles of the International Scientific and Practical Conference, held in Petrozavodsk on May 10, 2021. pp. 7-23. DOI 10.46916 / 12052021-1-978-5-00174228-9

15. Ismayilov K. Development of society and science in the digital economy. "Stability of compressed rods, plates and shells beyond the elastic limit" Petrozavodsk ICNP "New Science" Monograph. 2021 200s. ISBN 978-5-00174-2937. DOI 10.46916 / 19082021-1-978-5-00174-293-7.

16. Ismayilov K. Stress-strain state of a circular plate beyond the elastic limit. Innovative discourse of the development of modern science and technology. Collection of articles of the International Scientific and Practical Conference, held in Petrozavodsk on May 10, 2021. pp. 7-23. DOI 10.46916 / 12052021-1-978-5-00174228-9.

17. Власов В.3. Новый метод расчета тонкостенных призматических складчатых покрытий и оболочек.-М.-Д.: Госстройиздат, 1933. - 113 с. 


\title{
Коллектив авторов:
}

Андрианова Л.П., Белоножко М.Л., Гадзаова Л.П., Гордеева В.В., Данилов О.Ф., Ибрагимов А., Ковалева И.Е., Котова Е.Г., Кузнецова Н.В., Леонтьева А.В., Леонтьева Т.А., Линева Е.А., Лихтенштейн Б.М., Логинов С.И., Назаренко И.М., Назарова А.С., Савельева Е.Б., Сирожиддинов 3., Соколенко В.В., Таланова М.В., Чумаков А.А., Юсупова Т.Г., Яхшибоев Ш.Р.

НАУЧНОЕ ИЗДАНИЕ

СТРАТЕГИЯ НАУЧНО-ТЕХНОЛОГИЧЕСКОГО РАЗВИТИЯ РОССИИ: ПРОБЛЕМЫ И ПЕРСПЕКТИВЫ РЕАЛИЗАЦИИ

\author{
Монография \\ Подписано в печать 04.02.2022. \\ Формат 60x84 1/16. Усл. печ. л. 17,32. \\ Тираж 500 экз. \\ МЦНП «Новая наука» \\ 185002, г. Петрозаводск \\ ул. С. Ковалевской д.16Б помещ. 35 \\ office@sciencen.org \\ www.sciencen.org
}

